\title{
Balancing rangatiratanga and kawanatanga: \\ Waikato-Tainui and Ngāi Tahu's \\ Treaty settlement negotiations with the Crown
}

\author{
Martin Fisher
}

\begin{abstract}
A thesis
submitted to the Victoria University of Wellington

in fulfilment of the requirements for the degree of

Doctor of Philosophy

in History
\end{abstract}

Victoria University of Wellington

2015 


\begin{abstract}
Waikato-Tainui and Ngāi Tahu's negotiations with the Crown produced the first two major iwi-based agreements of the modern era of Treaty settlements in New Zealand/Aotearoa. While the existing historiography has previously addressed the general parameters of each agreement, and some key players have briefly written about their involvement in the process, an analysis of both negotiations through the lens of the iwi (tribe) pursuit of rangatiratanga (or self-determination) and the Crown's defence of its sovereignty and kawanatanga (or governance) increases our understanding of these precedent-setting Treaty settlements. Māori rangatiratanga and Crown sovereignty and governance were not the only factors that drove all parties in their negotiations, but they represented the dominant motivating force in terms of reaching agreements on very difficult issues.
\end{abstract}

Through an investigation of Ngāi Tahu, Waikato-Tainui, Crown and public sources, this thesis identifies the balancing of iwi rangatiratanga and the Crown's sovereignty and kawanatanga in four major areas of the process: the development of iwi governance systems post-settlement, the negotiation of the financial aspects of the settlement, the parameters surrounding the return of land, and the formulation of the historical accounts and Crown apologies. The political structures set by the Crown to govern the process influenced all aspects of the negotiation. Waikato-Tainui and Ngāi Tahu argued that a larger quantum would be necessary to achieve the finality and general financial certainty sought by the Crown, but were challenged most prominently by Treasury. Nonetheless both iwi were able to obtain significant concessions. The subsequent limit set on the total financial scope of each settlement also influenced the amount of land that was returned. In addition the Crown’s overall control of the process influenced the type of Crown lands that would be returned, and in Waikato-Tainui's case, the legal form in which land was returned. The negotiations 
regarding the historical accounts and apologies that accompanied each settlement similarly were influenced by the limitations imposed by the Crown, in contrast to the specific details sought by Ngāi Tahu and Waikato-Tainui.

The Crown was able to strengthen its governance by achieving settlements with Waikato-Tainui and Ngāi Tahu. Both iwi also were able to enhance their own rangatiratanga by settling their claims, enhancing their political power and influence regionally and nationally. Ultimately Waikato-Tainui and Ngāi Tahu’s Treaty settlements simultaneously reinforced the Crown's sovereignty and kawanatanga and energised Ngāi Tahu and WaikatoTainui’s pursuit of rangatiratanga. 


\begin{abstract}
About the author
Martin Fisher was born in Budapest, Hungary and grew up in Toronto, Canada and Wellington, New Zealand. He obtained a BA (Hons) from the University of Otago in 2006, and a Master of Arts (History) at McGill University in Montreal, Canada in 2008. Martin worked as an academic tutor for a range of courses in History, Political Studies and Management at the University of Otago, McGill University and Victoria University of Wellington. Before commencing his academic career, he worked in the Treaty of Waitangi claims process as a contractor researcher and, later, as a public servant. He is the author of reports commissioned by the Waitangi Tribunal, the Crown Forestry Rental Trust, and the Office of Treaty Settlements. From 2012-2014 Martin worked as a Research Analyst/Inquiry Facilitator at the Waitangi Tribunal. In 2014 he joined the University of Canterbury’s Ngāi Tahu Research Centre as a lecturer.
\end{abstract}




\section{Acknowledgments}

First and foremost I’d like to thank my primary supervisor, Professor Richard S. Hill, for seeing this through from the beginning six long years ago. Placed in the precarious position of supervisor as well as subject in the story, Richard has provided me with the valuable insights of an inside player in the early years of New Zealand's Treaty settlement process while also encouraging me to analyse the process, even if it meant criticising him! Great thanks are also due to my secondary supervisors, first Professor James Belich and then Cybele Locke, who each endured about three years with me. Without their encouragement and advice I would not have been able to finish this thesis. I especially would like to thank Cybele for her frank assessment of my work so late in my enrolment, it helped me immeasurably and strengthened my thesis. I consider myself extremely fortunate to have been supervised by three excellent historians. Jim McAloon from the Victoria University of Wellington History Department offered many useful suggestions during the final stages of drafting. I’m also grateful for the feedback provided by a former ToWPU official, Denese Henare, Shane Solomon, Anake Goodall, Bob Gregory and two OTS officials. Nonetheless, I take full responsibility for any faults that remain in my work.

Other Stout Research Centre staff and residents such as former director Professor Lydia Wevers and former administrator Louise Grenside also provided help and encouragement. Conversations with fellow Ph.D candidate Therese Crocker were especially valuable. I found the Stout a very intellectually stimulating environment in which to work and am grateful for the space made available for me there.

A number of friends have had the unfortunate experience of listening to my rants about the Treaty settlement process and I'd exceed my word count if I named them all, but a 
few were even subjected to reading drafts. I want to thank Alex Luty, Jack Doig, Jake Pollock and Jonathan West for your comments and advice. There was one person who read the most ${ }^{1}$ and without him I probably could not have completed this thesis, and that is Michael Allen. I can’t even begin to count the hundreds of discussions we've had over the past five years about my thesis and the Treaty settlement process. Thanks bro, this thesis would have been way worse without you.

Histories are only as good as their sources so I'd like to thank the librarians and archivists of the Victoria University of Wellington library, Archives New Zealand (with the permission of Sir Douglas Graham), Television New Zealand Archive, the New Zealand Film Archive, the Office of Treaty Settlements, the Macmillan Brown Library, Te Runanga o Ngāi Tahu archives and the Waikato-Tainui College for Research and Development for access to vital and often untouched sources. I'd especially like to acknowledge Waikato-Tainui and Ngāi Tahu for providing me the opportunity to consult your taonga (treasures).

I’d also like to thank those who agreed to conduct informal interviews: Sir Douglas Graham, Sir Tipene O’Regan, Denese Henare, Shane Solomon, Brent Wheeler, Richard Meade, Anake Goodall, Te Maire Tau, Nanaia Mahuta, Alex Frame, four Treaty of Waitangi Policy Unit officials, one Crown Law official and one Treasury official.

Various sources of funding enabled me to finance my study and to travel to archives in Christchurch and Hopuhopu outside of Hamilton: a Victoria University of Wellington Vice-Chancellor’s PhD Scholarship (2008-2011), Victoria University of Wellington Faculty of Humanities and Social Sciences Research Grants, and a Sir Robert Mahuta Memorial Scholarship.

\footnotetext{
1 ... and lent me money when I needed it, bought me lunch when I needed it, listened to whatever problem I had when I needed it....
} 
My small whanau, consisting of my parents, Zsuzsanna Lonti and Peter Fisher, my brother, Mat Fisher, and my grandmother, Maria Lonti, provided invaluable support over the years. Although we live far apart spread across the globe, you all have always been there for me. Köszönöm szépen rémelem hogy finom lesz.

Martin Fisher

April 2015 


\section{Contents}

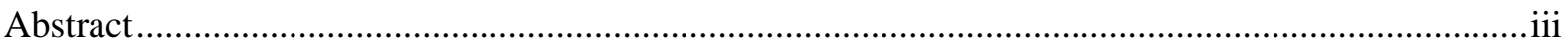

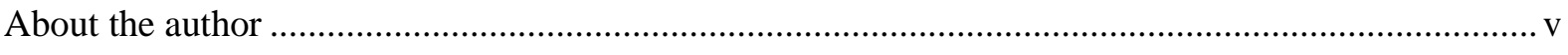

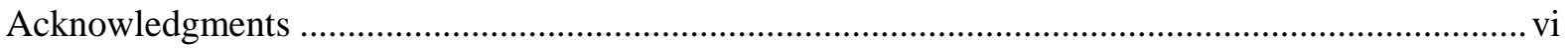

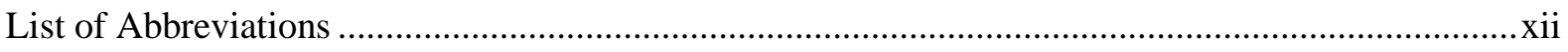

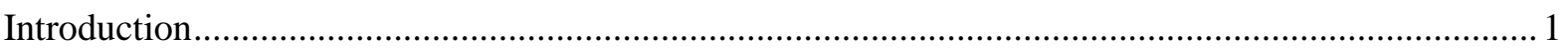

A Brief History of Waikato-Tainui and Ngāi Tahu Interactions with the Crown pre-negotiation ..... 6

A Brief History of the Modern Treaty of Waitangi Claims Process ................................................. 14

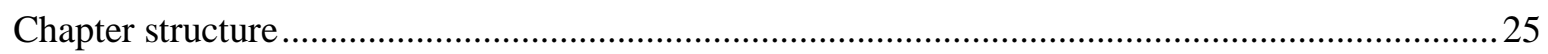

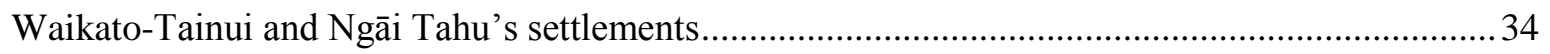

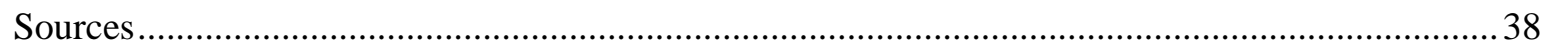

Chapter 1: The Politics of Negotiations: kawanatanga and rangatiratanga ..........................................45

Part I: Waikato-Tainui’s negotiations with the Fourth Labour government and Fourth National

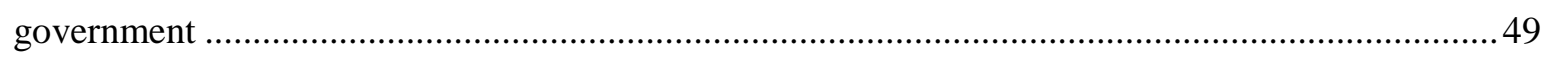

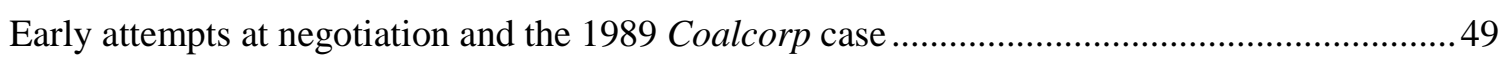

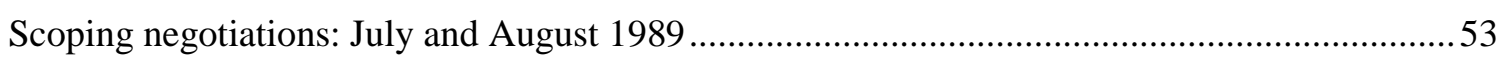

Finality and the Waikato Maniapoto Claims Settlement Act 1946: 1990.....................................57

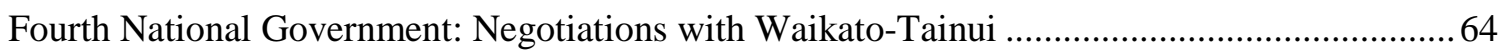

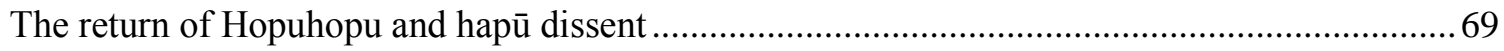

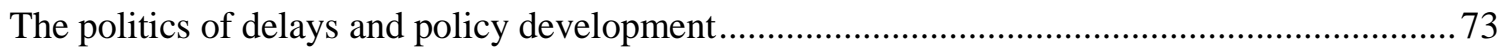

Part II: Ngāi Tahu's negotiations with the Fourth Labour Government and Fourth National

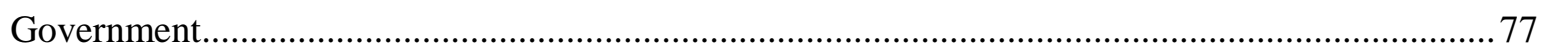

Waitangi Tribunal hearings and the development of the first land-bank ...................................... 77

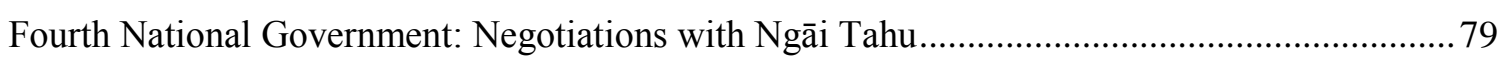

The establishment of Te Rūnanga o Ngāi Tahu and rangatiratanga .............................................. 81

Internal opposition from Waitaha, Tuhuru and Ngāti Mamoe.................................................... 88

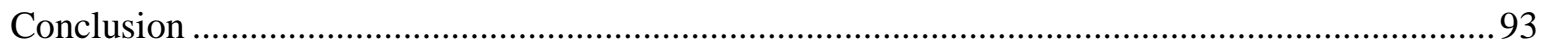

Chapter 2: The Economics of Ngāi Tahu and Waikato-Tainui’s Treaty settlements ...........................95

Part I: Ngāi Tahu, quantification of loss and the fiscal envelope ..................................................100

Divergent views: Ngāi Tahu "rights” vs. Treasury "needs" ...................................................... 100

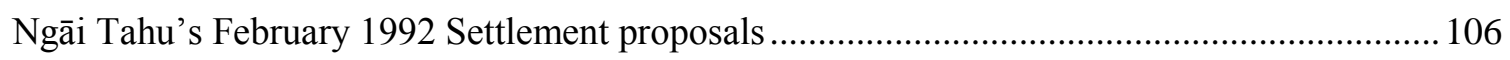

Ngāi Tahu and the Crown's internal development of the fiscal envelope: 1992-1994 ................116

Part II: Waikato-Tainui’s Treaty settlement, the fiscal envelope and the relativity clause..............119

Waikato-Tainui, the fiscal envelope and finality ...................................................................... 119 
Waikato-Tainui and the relativity clause 129

Waikato-Tainui’s Treaty settlement and the reactions from Māoridom ....................................137

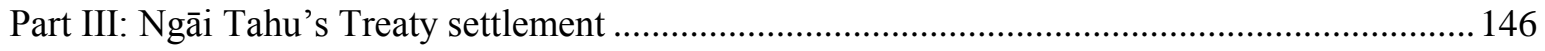

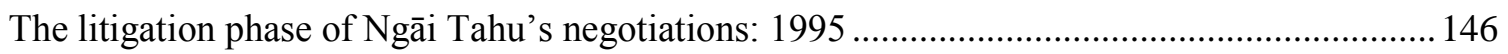

From recommencement of negotiations to Heads of Agreement, Ngāi Tahu's negotiations: 1996

Conclusion .

Chapter 3: Settling the land..... 162

Part I: Ngāi Tahu. 164

The operation of Ngāi Tahu's land-bank . 168

The three high-country pastoral leases: Elfin Bay, Greenstone and Routeburn Stations. 168

The return of sites of cultural significance. 170

The Arahura River 180

Whenua Hou and the Crown Titi Islands. 181

Part II: Waikato-Tainui . 184

The gradual development and eventual establishment of Waikato-Tainui's land-bank ...... 193

Waikato-Tainui and the return of land 193

Waikato-Tainui and the return of DoC land . 200

Waikato-Tainui's desire for customary title 201

Marginal strips 203

The removal of protection memorials on SOE lands along the Waikato River. 205

The effect of previous owners of Crown land on the return of land to Waikato-Tainui: Te Rapa Airbase and Ohinewai Coalcorp lands. 209 Conclusion ..... 218

Chapter 4 - The Politics of History and Treaty Settlements: The Formulation of Historical Accounts (preambles) and Apologies 220

Part I: The development of Waikato-Tainui's preamble(s) and apology ......................................223

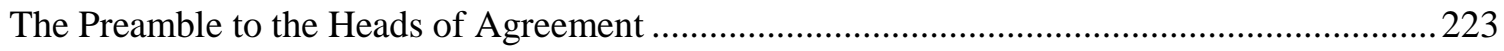

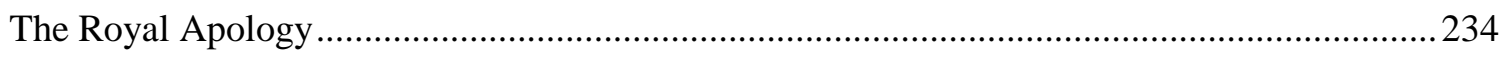

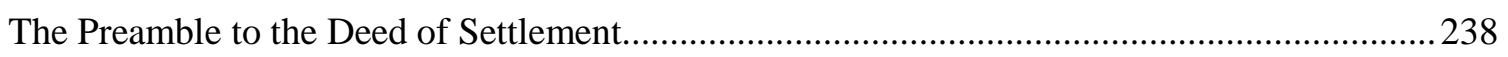

The Preamble to the Waikato Raupatu Claims Settlement Act 1995 ...........................................241

W.H. Oliver, the preamble to the Waikato Raupatu Claims Settlement Act 1995 and the return of confiscated lands in the nineteenth century ............................................................................24

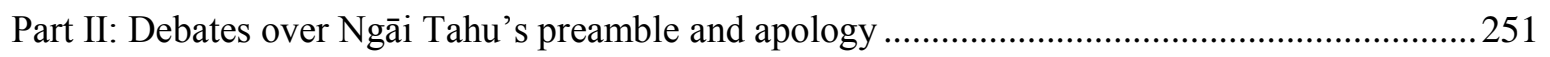

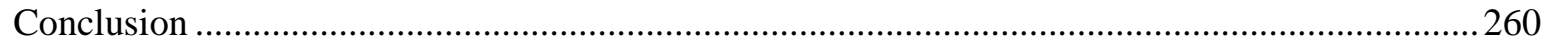

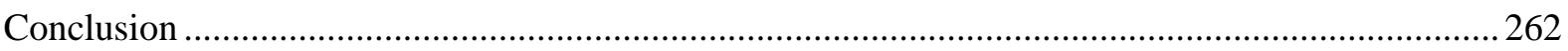




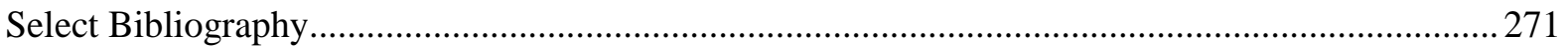

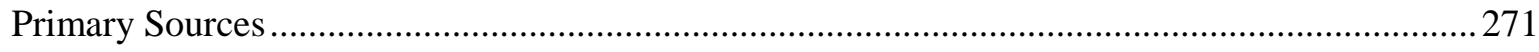

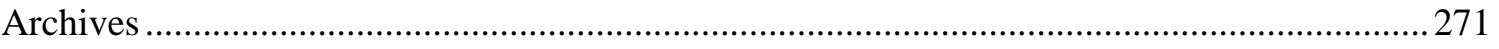

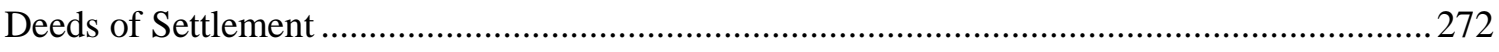

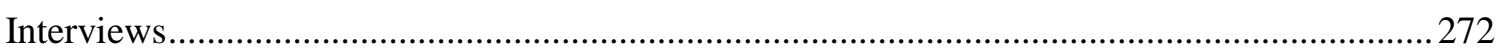

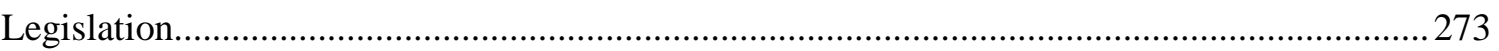

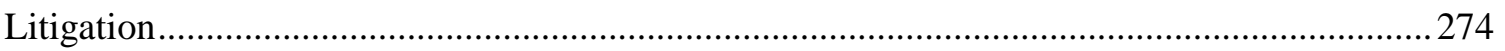

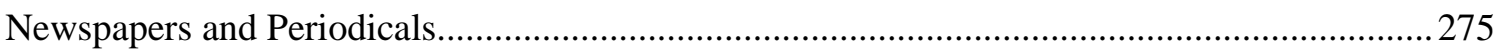

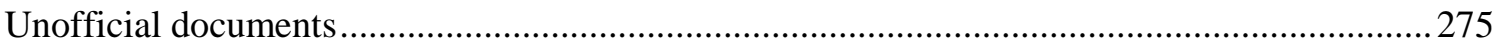

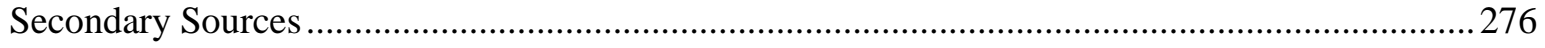

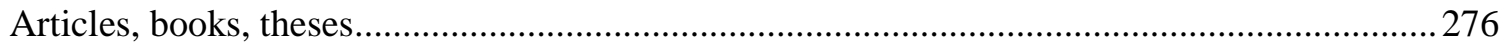

Waitangi Tribunal Reports and other unofficial documents ......................................................285

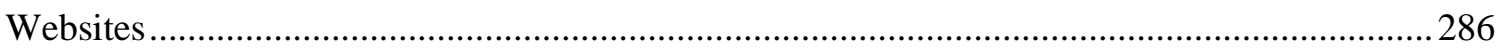




\section{List of Abbreviations}

CLO Crown Law Office

DoC Department of Conservation

DoSLI Department of Survey Lands and Information

DPMC Department of Prime Minister and Cabinet

DSP Deferred Selection Process

ECNZ Electricty Corporation of New Zealand

GDP Gross Domestic Product

HNZ Housing New Zealand

MB Macmillan Brown Archives

MFAT Ministry of Foreign Affairs and Trade

NTMTB Ngāi Tahu Māori Trust Board

OECD Organisation for Economic Cooperation and Development

OTS Office of Treaty Settlements

PCO Parliamentary Counsel Office

RFR Right of First Refusal

SOE State Owned Enterprise

TMTB Tainui Māori Trust Board

ToWPU Treaty of Waitangi Policy Unit

TPK Te Puni Kōkiri

TRONT Te Rūnanga o Ngāi Tahu

UN United Nations

VNZ Valuation New Zealand

W-T Waikato-Tainui 


\section{Introduction}

Since the mid-nineteenth century Māori groups in New Zealand have been seeking resolutions to their grievances with the British Crown, and successive New Zealand governments for breaching the terms of the Treaty of Waitangi signed in 1840 . These grievances related to a variety of issues surrounding the acquisition of land, resources and the undermining of Māori sovereignty. By the late twentieth century, many of these issues remained unresolved despite some minor attempts by governments in the nineteenth century and in the early and mid-twentieth century to address Māori historical grievances through various Commissions of Inquiry and the provision of very modest forms of compensation. Two major Māori groups that had been seeking some form of compensation and apology for decades were Waikato-Tainui and Ngāi Tahu. This thesis will explore the negotiations that gave rise to Treaty settlements between the Crown and Waikato-Tainui and Ngāi Tahu iwi (tribes) at the end of the twentieth century. These negotiations embodied the difficulty at the core of the Treaty of Waitangi relationship — the balance between Waikato-Tainui and Ngāi Tahu rangatiratanga--what they pereceived as self-determination or autonomy--and the Crown’s kawanatanga--what Waikato-Tainui and Ngāi Tahu viewed as the right to govern, and the Crown perceived as its sovereignty.

In 1840 hundreds of Māori leaders around New Zealand signed the Treaty of Waitangi with the British Crown. ${ }^{2}$ Māori leaders viewed the Treaty as a political compact that would enable the British to control their subjects that were living in New Zealand, and

\footnotetext{
${ }^{2}$ Throughout this thesis the Crown will refer to the Executive branch of government: Ministers, government Departments and agencies and officials. See Janine Hayward, "In search of a Treaty partner: who, or what, is the Crown?” Thesis (Ph.D.)--Victoria University of Wellington, 1995, for an excellent discussion of the difficulty of defining the Crown as a Treaty Partner.
} 
work in concert with their Treaty partner to govern but Māori would retain their independent sovereignty. The British believed they had acquired sovereignty. The Treaty was a concise document and had only three articles, but it was written in both English and Māori. While the third article was fairly accurately translated, the first two articles had significant differences and laid the basis for philosophical and practical disagreements between the two Treaty partners-Māori and the Crown. ${ }^{3}$ In article 1 of the English version Māori leaders gave Queen Victoria “all the rights and powers of sovereignty” over their lands. In the Māori version of article 1 it gave the Queen “te kawanatanga katoa”- the right to govern over their lands. In article 2 of the English version Māori leaders and people were guaranteed "exclusive and undisturbed possession of their lands and estates, forests, fisheries, and other properties”, but in the Māori version they were guaranteed "te tino rangatiratanga”- the unqualified exercise of chieftainship or self-determination over their lands, villages, and all their treasures. ${ }^{4}$ (The third article guaranteed to Māori all the rights and privileges of British subjects.) The British Crown and later the New Zealand government claimed that the Treaty of Waitangi had established Crown sovereignty, while Māori claimed that they had merely granted the Crown the right to govern. Māori claimed that the second article of the Treaty had guaranteed them their continuing rangatiratanga or self-determination. The Crown claimed that it had undisputed sovereignty as a result of the first article. These differences in interpretation have remained and emerged in direct negotiations between Waikato-Tainui and the Crown, and Ngāi Tahu and the Crown.

Waikato-Tainui's negotiations with the Crown formally began in 1989 without a Waitangi Tribunal hearing and a Final Agreement was signed in 1995 with legislation passed

\footnotetext{
${ }^{3}$ Alan Ward, An Unsettled History: Treaty Claims in New Zealand Today (Wellington: Bridget Williams Books, 1998), 13-18; Claudia Orange, The Illustrated History of the Treaty of Waitangi (Wellington: Bridget Williams Books, 2004), 39-41.

${ }^{4}$ Ruth Ross, “Te Tiriti o Waitangi: Texts and Translations,” New Zealand Journal of History, 6, 2 (1972).
} 
in Parliament recognising the settlement later that same year. Ngāi Tahu had their claims heard by the Waitangi Tribunal from 1987-1989 and their direct negotiations began soon after the Ngāi Tahu Report was released in early 1991. Their negotiations had two distinct phases, from 1991 to late 1994 and then early 1996 to 1997, with legislation formalising their settlement in 1998.

This thesis explores how Waikato-Tainui and Ngāi Tahu sought to negotiate settlements to their historical grievances that would empower them socially and politically, not just restore a lost economic base. ${ }^{5}$ However, the framework for settlement developed by the Crown did not meet these expectations. While Māori themselves have been able to choose which body will represent them in negotiations, the Crown has determined how negotiations will take place and the parameters within which Māori expectations could be fulfilled.While the Treaty of Waitangi Policy Unit (which would become the Office of Treaty Settlements in 1995) led the development of Treaty settlement policy and spearheaded the direct negotiations, the key institutions in determining these parameters have been the Crown Law Office and Treasury. Their role is to ensure that settlements have limited or controllable legal implications (Crown Law) and were affordable in relation to other areas of government expenditure (Treasury). The Crown has sought to engage in Treaty settlements so that New Zealand's economic and political conditions could be made more stable, and in doing so has attempted to make settlements full and final. However, the parameters placed upon settlements have never acknowledged the full range of aspirations Māori have sought from Treaty settlements, not only in fiscal terms (the amount of redress made available to them), but also in the way that their political authority (mana and rangatiratanga) might be recognised in the process. This is partly because the Crown's approach to negotiations has

\footnotetext{
${ }^{5}$ Andrew Sharp, Justice and the Māori: The Philosophy and Practice of Mãori Claims in New Zealand since the 1970s (Oxford: Oxford University Press, first ed. 1990, 1997), 1-12.
} 
been to protect its sovereignty. During its negotiations with Waikato-Tainui and Ngāi Tahu, the Crown strove to maintain its sovereignty in the face of Māori demands to have their political authority -defined in Treaty terms as rangatiratanga—recognised. The process by which this played out during the negotiations is the major focus of this thesis. This process saw the negotiating parties "talking past each other”, in many respects, and eventually leading to compromises that resulted in a settlement. ${ }^{6}$ While the iwi may have perceived, perhaps correctly so, that their compromises were far greater than the Crown was willing to make, the number of concessions they achieved were also significant.

Both Waikato-Tainui and Ngāi Tahu inserted the pursuit of rangatiratanga into the negotiations, especially in terms of the return of land. The Crown was very hesitant as it perceived there was little to discuss in relation to sovereignty or autonomy since it was the sole and undisputed sovereign. The issue of compensation that had formed the initial framework for the Crown's thinking would become a point of contention. Throughout both negotiations there remained a disjunction between the Crown's view of the political nature of any negotiated solution, and the need for some kind of structured system for Waikato-Tainui and Ngāi Tahu in which the extent of loss could be measured equally with the amount of compensation and apology provided. Coming into the negotiations the Crown would have been clear on its position on full and final settlements, but Waikato-Tainui and Ngāi Tahu were firm in their own belief that the fiscally limited settlements could not be full and final. These opposing views were the basis for the negotiations between the Crown and WaikatoTainui and Ngāi Tahu and the settlements themselves were ultimately the product of consensus on these differing points. These negotiations require some historical

\footnotetext{
${ }^{6}$ Joan Metge and Patricia Kinloch, Talking Past Each Other (Wellington: Victoria University Press, 1978).
} 
contextualisation. Before setting out a summary of the settlements and a chapter structure, the following sections detail iwi histories and the modern Treaty claims process. 


\section{A Brief History of Waikato-Tainui and Ngāi Tahu Interactions with the Crown pre-negotiation}

Waikato-Tainui iwi are based in the central north west of the North Island centred around Ngāruawāhia and extended out to the West Coast around Raglan and Kawhia and east down past Hamilton, and north towards Auckland stopping at approximately Port Waikato. Boundaries between whanau (family), hapū (sub-tribe) and iwi have always been fluid, marked by shared areas of influence and that remains so today. ${ }^{7}$ Ngāi Tahu are spread across most of the South Island with their region of interest spreading just south of Blenheim on the east coast of the South Island and up past the West Coast of the South Island. In 1990, the Māori Appellate Court confirmed the boundaries noted in the map below but it was challenged by other iwi in the north of the South Island, Te Tau Ihu, who also shared interests in some areas with Ngāi Tahu. ${ }^{8}$ Waikato-Tainui and Ngāi Tahu had very different historical experiences with the Crown. Waikato-Tainui's grievances were centered on the confiscation of approximately 1.2 million acres of land and the devastation from the wars of the 1860s. Ngāi Tahu's grievances stemmed from the Crown's faulty purchase of 34.5 million acres of land over twenty years from 1844 to 1864 . Both groups ended up in very similar positionsdepleted of land and resources, their social and economic positions within New Zealand society were severely undermined.

\footnotetext{
${ }^{7}$ Evan TS Poata-Smith, "The Changing Contours of Māori Identity and the Treaty Settlement Process," in Janine Hayward and Nicola Wheen (eds.), The Waitangi Tribunal (Wellington: Bridget Williams Books, 2004), 168-183.

${ }^{8} 4$ South Island Appellate Court Minute Book 673 Folio 6/3.
} 


\section{Map 1: Land confiscated in the Waikato ${ }^{9}$}

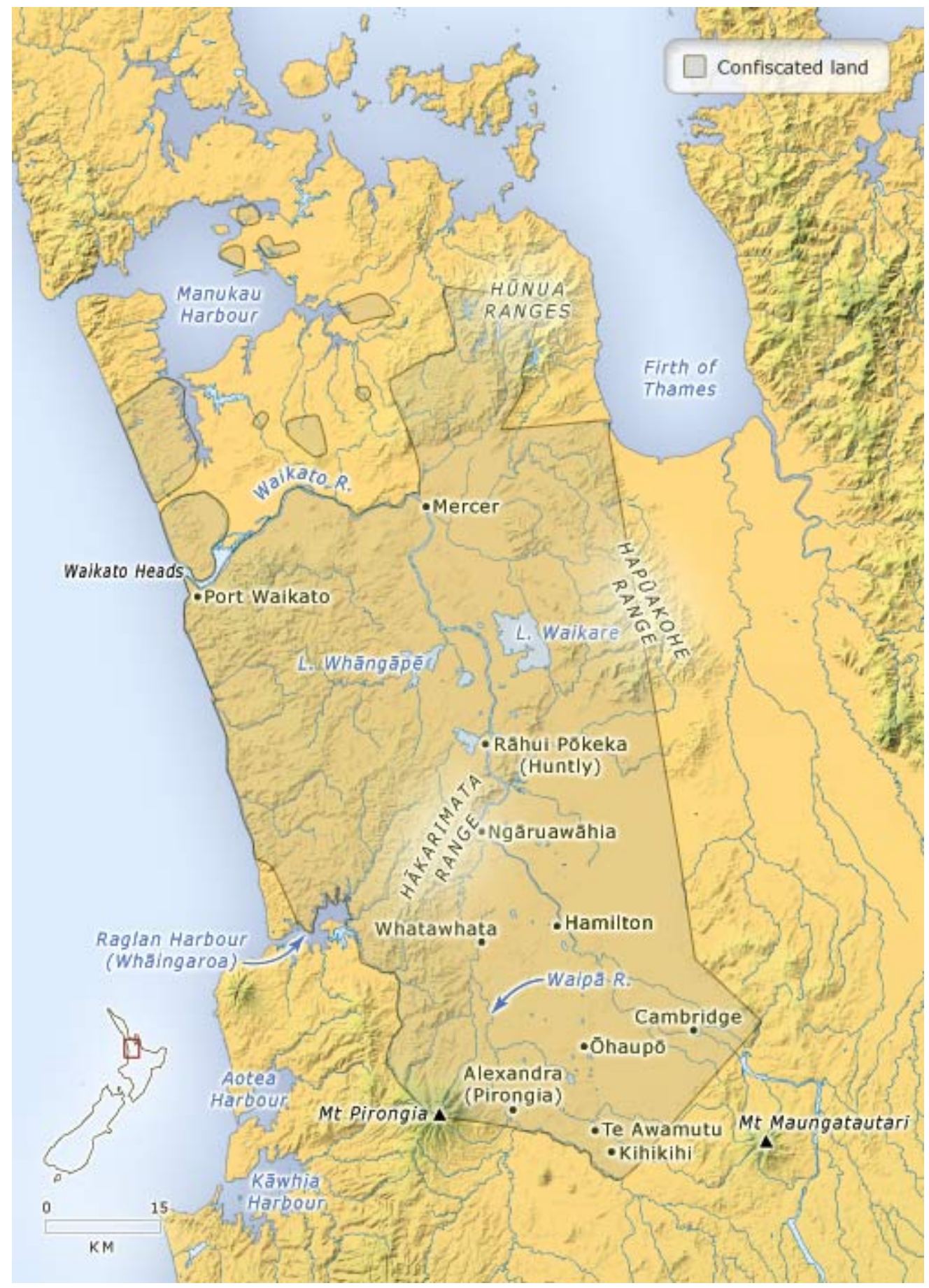

9 “Confiscation of Māori land,” <http://www.teara.govt.nz/en/map/27791/confiscation-of-Māori-land $>$, accessed 24 April 2013. 


\section{Map 2: Ngāi Tahu land purchases, $1844-1864^{10}$}

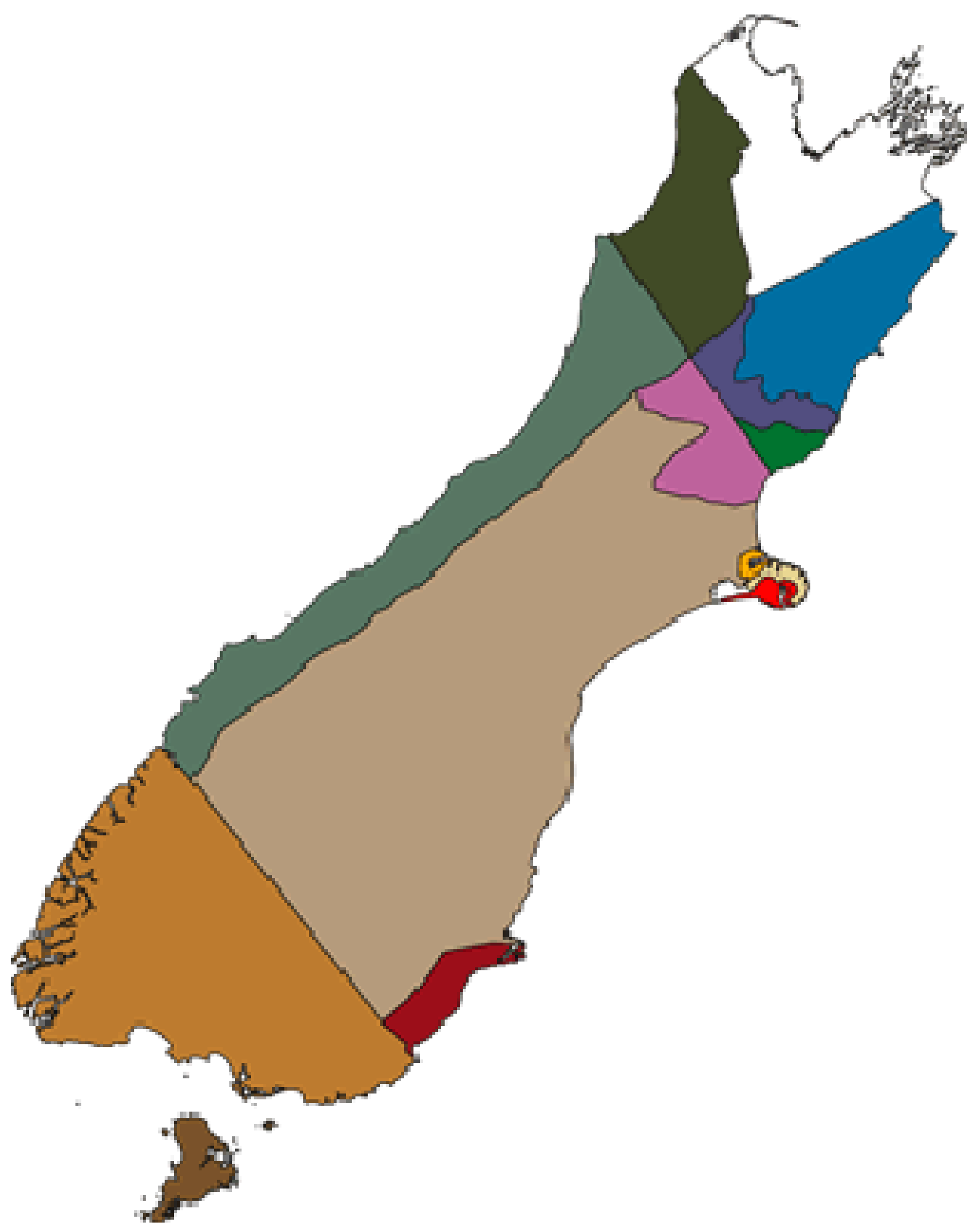

Ngāi Tahu’s grievances against the Crown stretched back to the 1840s. Ngāi Tahu had engaged in whaling and sealing enterprises in the early nineteenth century and believed that their land sales to the Crown and Europeans would guarantee their own usage rights to the resources in the region and strengthen robust political, economic and social relationships with

10 "Ngā Hoko i Ngāi Tahu,"” <<http://www.tiritiowaitangi.govt.nz/maps/ngaitahupurchases.php >>, accessed 24 April 2013. 
newcomers. The amount of land sold in the less densely populated South Island was enormous compared to the land sales in the North Island. From 1844-1864 Ngāi Tahu sold 34.5 million acres of land over eight separate purchases. Promises of schools and hospitals were especially emphasised to justify the low prices paid. ${ }^{11}$ Ngāi Tahu were promised substantial reserves in addition to the areas directly around their settlements to include food gathering areas. The Crown failed to safeguard the reserves negotiated in the purchases. The Crown left Ngāi Tahu marginal and miniscule reserves and within a generation of the first land sale Ngāi Tahu were left landless and impoverished as settlers were provided with cheap and wide-ranging estates throughout the region. ${ }^{12}$

Ngāi Tahu took their first case to Court in 1868 but the government passed legislation, the Ngaitahu Reference Validation Act 1868, to prevent their claims from being heard. ${ }^{13}$ In the late 1870s, the Smith-Nairn Commission made some initial inquiries into Ngāi Tahu’s grievances but the funding for this inquiry was halted before it could make any conclusions or recommendations. Later in 1887, Royal Commissioner Alexander Mackay recommended the return of land and the payment of compensation, but a change of government meant that his Commission’s report was ignored. Select Committees of Parliament looked into the Ngāi Tahu claim again in 1889 and 1890, and in 1891 Alexander Mackay travelled around the South Island documenting the poverty of Ngai Tahu. Just as in 1887, Mackay recommended the return of land and the payment of compensation. In1906 inaccessible mountainous lands that would have been impossible to farm without substantial capital were transferred to some Ngāi Tahu but did not address the poverty of the people. ${ }^{14}$ Ngāi Tahu continued to petition the government throughout the late nineteenth and early

\footnotetext{
${ }^{11}$ Vincent O’Malley, “Beyond Waitangi: Post-1840 Agreements Between Māori and the Crown,” in Beyond the Imperial Frontier (Wellington: BWB, 2014), 44-70.

${ }^{12}$ Waitangi Tribunal, The Ngāi Tahu Report, (Wellington: Waitangi Tribunal, 1991), 175-214, 821-920.

${ }^{13}$ Waitangi Tribunal, The Ngāi Tahu Report, 503-524.

${ }^{14}$ South Island Landless Natives Act 1906.
} 
twentieth centuries. When Prime Minister Peter Fraser began to pay some compensation to Māori groups in the 1940s Ngāi Tahu was provided with an annual sum of $£ 10,000$ for thirty years. This was a small amount that quickly devalued with inflation and was seen by many members of Ngāi Tahu as a temporary measure. Some Ngāi Tahu leaders, especially those that had negotiated the compensation, were initially pleased with the settlement. Later it was perceived that the compensation had been forced upon Ngāi Tahu. The iwi continued to petition the government regarding its claims. ${ }^{15}$

The origins of Waikato-Tainui’s grievances were also centered on the control of land. Many hapū around New Zealand had begun to resist land sales in the 1850s. This resistance developed alongside the idea of establishing a Māori King to advocate for the retention of Māori land and sovereignty. After Māori rangatira such as Piri Te Kawau of Te Āti Awa (in 1843) and Tamihana Te Rauparaha of Ngāti Toa (in 1852) met Queen Victoria in England, they returned to New Zealand determined to promote the idea of a Māori king. These rangatira believed that they could nominate a sovereign equal to Queen Victoria, settle intertribal conflict, establish self-governing institutions and retain Māori land. With the help of Ngāti Raukawa rangatira Matene Te Whiwhi, Tamihana Te Rauparaha set out during the mid 1850s to travel around the North Island trying to convince the leaders of major iwi such as Tainui, Ngati Porou, Whanganui, Te Arawa and Ngāti Tūwharetoa to accept the role and title of King but he could not find anyone who wanted the role. Finally, in 1858 the leader of Tainui iwi Ngāti Mahuta, Te Wherowhero, accepted the role and title of King after having initially rejected it in 1856. The Kīngitanga or King Movement was formally established in

\footnotetext{
${ }^{15}$ Waitangi Tribunal, The Ngāi Tahu Report, 1003-1032; Te Maire Tau, "Ngāi Tahu - From 'Better Be Dead and Out of the Way' to 'Be Seen and to Belong,' in in J. Cookson and G. Dunstall (eds.) Southern Capital, Christchurch: Towards a City Biography (Christchurch: Canterbury University Press, 2000), 222-231.
} 
1858. Ngāti Hauā rangatira Wiremu Tamihana, also known as the Kingmaker, crowned Te Wherowhero as King Pōtatau in 1859 at Ngāruawāhia. ${ }^{16}$

Pōtatau died a year later in 1860 and his son, Tāwhiao, was crowned as King in July 1860. In the first year of Tāwhiao’s reign, the Kīngitanga was drawn into the disputes over land sales that were occurring in the Taranaki region due to the King Movement's pan-tribal connections with those in Taranaki opposing land sales. In July 1863, Crown forces, determined to assert British sovereignty over Waikato Māori, crossed the Mangatawhiri River and directly attacked the Kinngitanga. While the Kinngitanga and its allies fought the Crown to a standstill in many battles, the overwhelming numbers of British soldiers and the part-time nature of the Kīngitanga army led to their eventual military defeat in 1864. The Kīngitanga and its allies were forced to retreat and take refuge in behind the military border, the 'aukati' The King was to take refuge in Ngāti Maniapoto and Ngāti Hikairo territories. ${ }^{17}$ Following their defeat, the Kīngitanga's power as a pan-tribal force was significantly curtailed as the Crown confiscated “rebel” lands in the Waikato, Taranaki and Tauranga regions. ${ }^{18}$ Nonetheless for over twenty years a parallel sovereignty would exist in the King Country, Te Rohe Pōtae, into which Pākehā settlers and Crown representatives could only enter with the permission of the Kīngitanga. ${ }^{19}$

\footnotetext{
${ }^{16}$ James Belich, The New Zealand Wars (Auckland: Penguin, 1998), 78-79; Evelyn Stokes, Wiremu Tamihana: Rangātira (Wellington: Huia, 2002), 134-189; David McCan, Whatiwhatihoe: The Waikato raupatu claim (Wellington: Huia, 2001), 25-58.

${ }^{17}$ James Belich, The New Zealand Wars, 196-200; Danny Keenan, Wars Without End: The Land Wars in Nineteenth Century New Zealand (Auckland: Penguin, 2009), 205-233; Evelyn Stokes, Wiremu Tamihana: Rangatira, 334-389; Cathy Marr, “Te Rohe Pōtae political engagement 1864-1886,” Report commissioned by the Waitangi Tribunal, Wai 898, A78, 2011.

${ }^{18}$ Bryan Gilling, "The Punitive Confiscation of Māori Land in the 1860s," in R Boast and R Hill (eds.) Raupatu: The Confiscation of Māori Land (Wellington: VUW Press, 2009), 13-30.

${ }^{19}$ Cathy Marr, “Te Rohe Pōtae political engagement, 1864-1886,” Report commissioned by the Waitangi Tribunal, Wai 898, A78, 2011; Ann Parsonson, "Te mana o te Kīngitanga Māori: a study of WaikatoNgātimaniapoto relations during the struggle for the King Country, 1878-1884,” MA thesis, University of Canterbury, 1972.
} 
In the Waikato, over 1.2 million acres of the most productive lands in the country were confiscated under the New Zealand Settlements Act 1863 as punishment for alleged Waikato-Tainui rebellion against the Crown. ${ }^{20}$ This punishment was executed in any rational way from the perspective of Māori groups living in the area. A main ally of Waikato-Tainui against the British—Ngati Māniapoto—-had unproductive lands south of Waikato-Tainui that were not confiscated at all while those who remained neutral and even supported the British government had their lands confiscated further north. ${ }^{21}$ From the Crown's point of view, the confiscations were rational because they facilitated European settlement by taking the most fertile land and funded the infrastructure to develop it. The confiscation of land was thus at the centre of Waikato-Tainui's grievances against the Crown. ${ }^{22}$ Following the confiscation of land Tāwhiao coined the key negotiating principle that would govern the strategy of WaikatoTainui negotiators for generations: "i riro whenua atu, me hoki whenua mai”—as land was taken, land must be returned. ${ }^{23}$

From the mid-1860s onwards, Waikato-Tainui leaders repeatedly petitioned the New Zealand and British governments regarding what they perceived as an unjust confiscation of their lands. The New Zealand government had begun its process of returning some confiscated lands to those Waikato Māori who pledged their allegiance to the Queen but the system was quite haphazard and followers of the King Movement did not participate. ${ }^{24}$ During the time Tāwhiao remained with his followers in Te Rohe Pōtae from 1864-1881, he continually negotiated with government representatives for the return of confiscated lands.

\footnotetext{
${ }^{20}$ The New Zealand Settlements Act 1863; Bryan Gilling, "The Punitive Confiscation of Māori Land in the 1860s," 23-24.

${ }^{21}$ Vincent O’Malley, “Choosing Peace or War: The 1863 Invasion of Waikato,” New Zealand Journal of History, Vol.47, No.1, 2013

${ }^{22}$ Robert Mahuta, "Tainui, Kīngitanga and Raupatu," in Margaret Wilson \& Anna Yeatman (eds.) Justice \& Identity: Antipodean Practices (Wellington: Bridget Williams Books, 1995), 23-25.

${ }^{23}$ Waikato-Tainui Claims Settlement Act 1995, Preamble.

${ }^{24}$ Richard Boast, The Native Land Court: A Historical Study, Cases and Commentary, 1862-1887 (Wellington: Brookers Ltd., 2013), 19-29, 37-39; Danny Keenan, Wars Without End: The Land Wars in the Nineteenth Century, 260-294.
} 
Once he returned to the Waikato in the 1880s he made the first of many visits by the Kīngitanga to England to petition the British royal family directly. ${ }^{25}$ In the 1920 s, the government established the Sim Commission to investigate some of the major Māori grievances against the government, one of which was the confiscation of land in the Waikato. The specific terms of reference for the Sim Commission were to determine whether the confiscations were "excessive.” The Sim Commission concluded that the confiscations were unjust but that Waikato-Tainui had been deserving of some kind of punishment because they had rebelled against the Crown. ${ }^{26}$ Waikato-Tainui argued that any confiscation had been unjust because they were defending their homes against British troops. Negotiations with the government began in the 1930s, and by 1946, Waikato-Tainui were granted a small amount of annual compensation, £5,000 annually for thirty years, under the Waikato-Maniapoto Claims Settlement Act that was eroded over the years by inflation. ${ }^{27}$ The legislation also established the Tainui Māori Trust Board, which managed and distributed the annual compensation. ${ }^{28}$ Most Waikato-Tainui leaders were not satisfied with the token annual sum while successive governments considered that the compensation provided was a full and final settlement. Some Waikato-Tainui leaders continued to pursue a fuller and more robust settlement of their claims against the government that included land. ${ }^{29}$

\footnotetext{
${ }^{25}$ David McCan, Whatiwhatihoe: The Waikato Raupatu Claim (Wellington: Huia, 2001), 148-150, 175-176.

${ }^{26}$ Mark Hickford, "Strands from the Afterlife of Confiscation, Property Rights, Constitutional Histories and the Political Incorporation of Māori, 1920s," R Boast and R Hill (eds.) Raupatu: The Confiscation of Māori Land (Wellington: VUW Press, 2009), 183-203.

${ }^{27}$ Michael King, Te Puea: A life (Auckland: Penguin, 1977), 222-225; McCan, Whatiwhatihoe: The Waikato raupatu claim, 186-209; Michael Belgrave, "Negotiations and Settlements” in Nicola Wheen \& Janine Hayward (eds.) Treaty of Waitangi Settlements (Wellington: Bridget Williams Books, 2012), 45.

${ }^{28}$ McCan, Whatiwhatihoe: The Waikato raupatu claim, 205-216; Richard Hill, State Authority, Indigenous Autonomy: Crown-Māori Relations in New Zealand/Aotearoa 1900-1950 (Wellington: Victoria University Press, 2004), 223-224.

${ }^{29}$ Robert Mahuta, “Tainui, Kīngitanga and Raupatu,” 25-28; David McCan, Whatiwhatihoe: The Waikato raupatu claim, 181-224.
} 


\section{A Brief History of the Modern Treaty of Waitangi Claims Process}

The modern Treaty of Waitangi claims process began in the 1970s although its roots go back further to other attempts by Māori to have their historical claims addressed by the Crown. The alienation of Māori land through faulty land sales, military confiscation and bureaucratic machinations such as the Native Land Court, survey costs and rates, was at the centre of many Māori grievances. As the land began to transfer from Māori to European/ Pākehā ownership so too did the management of the environment and the environment began to be degraded by the farming, mining, fishing and forestry industries. Thus, environmental issues also became a significant part of most Māori claims against the Crown. The 1967 Māori Affairs Amendment Act continued the Crown’s pattern of facilitating the alienation of Māori land, and the Act served to provide a common focus for different forms of Māori protest. $^{30}$

Māori protest was quite widespread and diverse by the 1970s - there were conservative, liberal and radical factions that often worked together, but also worked alone. Radical groups such as Ngā Tamatoa had developed a political philosophy influenced by Black Power movements in the United States and other organisations such as the American Indian Movement. Nonetheless in relation to the alienation of Māori land, organisations such as Nga Tamatoa were largely in agreement with the more conservative New Zealand Māori Council (NZMC). Other protests groups were associated with trade unions such as the Māori Organisation on Human Rights or with women’s rights, such as the Māori Women’s Welfare League and these groups also called for the Crown to resolve Māori grievances. In 1975 a Māori land march (hikoi) was organised by a group of Māori and some Pākehā activists, Te

\footnotetext{
${ }^{30}$ Richard Hill, Māori and the State: Crown-Māori Relations in New Zealand/Aotearoa, 1950-2000 (Wellington: Victoria University Press, 2009), 158-160.
} 
Roopu o te Matakite, that travelled from the Far North in Te Kaeo to Wellington to highlight the need for Crown action to halt the alienation of land and to resolve Māori claims. This march had developed directly out of the response to the Māori Affairs Amendment Act $1967 . .^{31}$

At the same time that these Māori protest movements were putting pressure on the government, Māori MPs also pushed the government to deal with Māori claims for historical redress. Matiu Rata was the Māori Affairs Minister from 1972-1975 for the Third Labour government. Before the Labour government was defeated by the National Party led by Robert Muldoon in 1975, Rata was able to introduce the Treaty of Waitangi Act, which established the Waitangi Tribunal. The Tribunal was a permanent commission of inquiry that was authorised to investigate breaches of the Treaty of Waitangi and make recommendations to the government, but only those breaches that had occurred after 1975. This limited the ability of the Tribunal to look into most Māori grievances, many of which had contemporary effects but which were historical in nature. The Tribunal was able to address some environmental claims, all of which related to the discharge of untreated sewage into rivers, streams and the ocean. The Tribunal recommended the treatment of sewage before disposal into water. ${ }^{32}$ The National Party, elected into government months after the Act was passed, limited the Waitangi Tribunal's ability to function by restricting financial support for the nine years they were in office. ${ }^{33}$ Issues that the Tribunal could have helped to resolve during the 1975 to

\footnotetext{
${ }^{31}$ E.S. Poata-Smith, 'He pokeke uenuku i tu ai: the evolution of contemporary Māori protest,' in Nga Patai: Racism and Ethnic Relations in Aotearoa New Zealand (Palmerston North: Dunmore Press, 1996); Aroha Harris, Hikoi: Forty Years of Māori Protest (Wellington: Huia, 2008), 70.

${ }^{32}$ MPK Sorrenson, 'The Waitangi Tribunal and the Resolution of Māori Grievances,' in Land is the Price (Auckland: Auckland University Press, 2014), 257-259.

${ }^{33}$ Paul Hamer, 'A Quarter-century of the Waitangi Tribunal,' in Janine Hayward and Nicola Wheen (eds.), The Waitangi Tribunal (Wellington: Bridget Williams Books, 2004), 3-5; Mason Durie, Te Mana, Te Kawanatanga (Auckland: Oxford University Press, 1998), 184; Jane Kelsey, 'From lame duck to toothless tiger,' Mana Magazine, No. 31993.
} 
1984 period, such as the occupation of Bastion Point, were instead left to grow and further Māori grievances were created. ${ }^{34}$

Despite the limits placed on the Waitangi Tribunal in its first decade of existence, some early findings were particularly important such as the historical context in which the Treaty was signed, recognition of the Māori text of the Treaty and the different Māori and European understandings of the Treaty especially with regard to issues related to sovereignty or rangatiratanga. ${ }^{35}$ The Tribunal's findings were supported and aided by academic publications such as Ruth Ross’s 1972 article “Te Tiriti o Waitangi: Texts and Translations,” and later Claudia Orange’s 1987 publication The Treaty of Waitangi which explored the debates that occurred during the signing of the Treaty of Waitangi in $1840 .{ }^{36}$ Other academics who explored New Zealand history through the lens of the Treaty of Waitangi during this time also fed into the process such as Alan Ward, Judith Binney, David Williams and Ann Parsonson. ${ }^{37}$ Although there were some significant findings produced by the Tribunal's inquiries, there was still a high level of Māori protest such as occupations of land at Orakei (Bastion Point) and Raglan, and annual protests during Waitangi Day commemorations. The Waitangi Action Committee came to prominence during the early 1980s, and advocated for the return of lands as their predecessors had in the 1960s and 1970s but increasingly questioned the role that the Treaty could play in such a process. Māori

\footnotetext{
${ }^{34}$ When the Tribunal heard its first historical claim in 1987 it was related to the occupation at Bastion Point and the Tribunal recommended the return of the entire area in dispute as well as other lands and compensation: Waitangi Tribunal, Report of the Waitangi Tribunal on the Orakei Claim (Wai-9), (Wellington: Brookers \& Friends, 1987).

35 Janine Hayward, 'Flowing from the Treaty’s words,' in Janine Hayward and Nicola Wheen (eds.), The Waitangi Tribunal (Wellington: Bridget Williams Books, 2004), 30-32.

${ }^{36}$ Ruth Ross, “Te Tiriti o Waitangi: Texts and Translations,” New Zealand Journal of History, 6, 2 (1972); Claudia Orange, The Treaty of Waitangi (Wellington: Allen \& Unwin, 1987); Rachael Bell, “Texts and Translations,' Ruth Ross and the Treaty of Waitangi,” New Zealand Journal of History, 43, 1 (2009).

${ }^{37}$ Alan Ward, A Show of Justice: Racial Amalgamation in Nineteenth Century New Zealand (Toronto: University of Toronto Press, 1973); Judith Binney, The Legacy of Guilt, A Life of Thomas Kendall (Auckland: Oxford University Press, 1968); Judity Binney, Gillian Chaplin and Craig Wallace, Mihaia: The Prophet Rua Kenana and his community at Maungapohatu (Auckland: Oxford University Press, 1979); Ann Parsonson, "He Whenua Te Utu (The Payment will be Land),” PhD thesis, University of Canterbury, 1978; David V. Williams, Te Kooti Tango Whenua: The Native Land Court 1864-1909 (Wellington: Huia Books, 1999).
} 
protest seemed to escalate each year during the late 1970s and early 1980s as protestors demanded, amongst other things, that the Tribunal be provided with powers to determine historical claims. ${ }^{38}$ Matiu Rata, frustrated with political intransigence within Labour, left the Party and formed Mana Motuhake in 1980. Rata’s new political party was meant to provide a middle point between radical direct action protest and a Labour Party that was perceived to be falling behind in the realm of Māori Affairs. ${ }^{39}$

Pressure from Māori MPs and Māori activists made the extension of the Tribunal's powers to investigate historical grievances a part of Labour's policy platform in 1984. The Treaty of Waitangi Amendment Act was passed in 1985 and it allowed for the Tribunal to inquire into Māori grievances against the Crown dating back to the signing of the Treaty on 6 February 1840. These retrospective powers would entail detailed historical research into specific Māori claims against the Crown over a period dating back to 1840. This caused a rapid increase in the number of claims submitted to the Tribunal and very soon the system was completely over-loaded but the Tribunal continued to remain under-resourced. The backlog of claims and the Tribunal's (initial) lack of binding powers eventually convinced some Māori groups to proceed directly to negotiations with the Crown.

When the Labour government introduced legislation to increase the investigative reach of the Waitangi Tribunal it also embarked on a neo-liberal economic agenda that clashed with its intention to resolve Māori grievances. ${ }^{40}$ In 1986 Parliament passed the State Owned Enterprises Act which sought to corporatise or privatise some of the most valuable

\footnotetext{
38 Ranginui Walker, Nga tau tohetohe: Years of Anger (Auckland: Penguin, 1987); Hill, Māori and the State: Crown-Māori Relations in New Zealand/Aotearoa, 1950-2000, 176-178.

${ }^{39}$ Hill, Māori and the State: Crown-Māori Relations in New Zealand/Aotearoa, 1950-2000, 178-181, 184, 201, 209.

${ }^{40}$ Jane Kelsey, A Question of Honour? Labour and the Treaty, 1984-1989 (Wellington: Allen \& Unwin, 1990), 3.
} 
Crown assets and land administered by government departments. ${ }^{41}$ The privatisation policies implemented during the second half of the 1980s were solely focused on economic rationalism, and originally these policies had not included any recognition of Māori claims. This was problematic for Māori because the government had also finally recognised their right to a fair hearing of their historical grievances. Any land or resources that had been acquired by the Crown in a way that breached the Treaty of Waitangi but had been sold into private hands were completely off limits in the claims process. ${ }^{42}$ Māori claimants could only receive government-owned lands and resources as compensation. The recognition of historical Treaty rights for Māori and the need and desire to privatise the economy were thus intertwined and also in many ways diametrically opposed.

In addition to the economic changes that were introduced during the second half of the 1980s, Labour was also intent on reforming the New Zealand political structure. Legislation was increasingly being written with the Treaty of Waitangi incorporated into its structure to ensure that the government would not be breaching the principles of the Treaty of Waitangi. This included legislation governing the corporate restructuring of government (The State Owned Enterprises Act 1986), the establishment of the Department of Conservation (The Conservation Act 1987), but also the Environment Act 1986, the Māori Language Act 1987, the Education Act 1989 and the Māori Fisheries Act 1989. This pattern would continue on through into the 1990s. Internal factions within the Labour Party that were opposed to the increasing place of the Treaty of Waitangi in the legislative system, such as Roger Douglas and Richard Prebble, believed that including the reference to the Treaty of Waitangi would appease the more progressive forces within the Labour Party such as Koro Wetere and Geoffrey Palmer. When Māori opposed the State Owned Enterprises Act in 1987 they used

\footnotetext{
${ }^{41}$ Claudia Orange, The Illustrated History of the Treaty of Waitangi, 162-163; Alan Ward, An Unsettled History, 34-37.

${ }^{42}$ Ward, An Unsettled History, 34-37.
} 
the wording in the government's own statutes to argue that the Treaty of Waitangi was being breached. The first legal challenge to the Labour government from Māori would appear in the Courts in $1987 .^{43}$

In the NZMC v. Attorney-General case the New Zealand Māori Council charged that the State Owned Enterprises Act 1986 breached the principles of the Treaty of Waitangi because the Act enabled the government to privatise land and assets, which would then become unavailable for use as compensation for Māori historical grievances. ${ }^{44}$ Sir Robin Cooke and his fellow justices in the Court of Appeal agreed that the legislation did breach the principles of the Treaty and forced the government to negotiate with Māori leaders to develop some safeguards that would protect land and assets from sale. The result was the Treaty of Waitangi (State Enterprises) Act 1988 which provided clawback mechanisms, called memorials, for land and assets that were subject to Māori claims. This meant that if a private interest wanted to purchase surplus state assets that had memorials, they were required to sell back the assets to the Crown if it was found that they were the subject of a valid claim. The 1988 Act also introduced binding 'remedial' powers for the Waitangi Tribunal in which it could force the Crown to return State Owned Enterprise land and assets if they were the subject of valid claims within 90 days of making the order. The Tribunal has only used its powers under the Act once, in $1998 .{ }^{45}$ In that instance the Crown and the claimants, Ngāti

\footnotetext{
43 Jane Kelsey, A Question of Honour? Labour and the Treaty, 1984-1989 (Wellington: Allen \& Unwin, 1990), 140-161.

${ }^{44}$ Orange, An Illustrated History of the Treaty of Waitangi, 164-166; Ward, An Unsettled History, 37-38; Michael King, Penguin History of New Zealand, 501.

${ }^{45}$ NZMC v. Attorney-General (1987); Hill, Māori and the State: Crown-Māori Relations in New Zealand/Aotearoa, 1950-2000, 223-226; Durie, Te Mana, Te Kawanatanga, 182-184. Recently the Supreme Court forced the Tribunal to at least grant a remedies hearing in the case of the Mangatu Incorporation: Haronga $v$ Waitangi Tribunal and others (SC54/2010) [2011] NZSC 53. Due to the pressure from the Supreme Court, the Tribunal also granted the Ngāti Kahu remedies inquiry in 2012. Both the Mangatu Remedies Tribunal and the Ngāti Kahu Remedies Tribunal declined to use their binding powers and order remedies: Ngāti Kahu Remedies Report, 2012; Mangatu Remedies Report, 2013. While some commentators have criticised the Tribunal for refusing to use their binding powers, there are a number of interrelated factors that have prevented its use.
} 
Turangitukua, negotiated a settlement before the Tribunal's binding powers came into effect. $^{46}$

Another agreement was also later negotiated in 1989 to cover the privatisation of state forests that resulted in the establishment of the Crown Forestry Rentals Trust. Rather than selling the land with a memorial on the title, the Crown retained ownership of the land and sold the cutting rights to the forests and leased the land. The Crown would set aside accumulated Crown forestry rentals for Māori claimants who would receive the compensation whenever their claim was found to be valid as well as fund the research for their direct negotiations. As with the lands and assets held by State Owned Enterprises, the Tribunal was also empowered to make binding orders for the return of Crown forests where it considered a claim to be well-founded. ${ }^{47}$

The other major Court case affecting Crown-Māori relations in the late 1980s was the Coalcorp case. Much as State Owned Enterprises, Crown forests and fisheries, minerals were found to be assets that could be used in the future for the settlement of valid Māori claims. Waikato-Tainui alleged that mineral wealth such as coal should equally be set aside by the Crown and used in a future settlement. Against the advice of most legal experts they filed an injunction in the Court of Appeal. The Courts once again backed the Māori claimants and instructed the government to halt the sale of Coalcorp assets in the Waikato so that they would be potentially available for Waikato-Tainui. ${ }^{48}$

\footnotetext{
${ }^{46}$ Waitangi Tribunal, The Turangi Township Remedies Report, 1995; Ngāti Turangitukua Deed of Settlement, 26 September 1998.

${ }^{47}$ Orange, An Illustrated History of the Treaty of Waitangi, 164-169, 185-187; Ward, An Unsettled History, 3840; Crown Forest Assets Act 1989.

${ }^{48}$ Orange, An Illustrated History of the Treaty of Waitangi, 196-197; David McCan, Whatiwhatihoe: The Waikato raupatu claim, 251-296; Hill, Māori and State: Crown-Māori Relations in New Zealand/Aotearoa 1950-2000, 227.
} 
During the negotiations and Court hearings over the State Owned Enterprises Act, the Crown Forest Assets Act, the Māori Fisheries Act and the Coalcorp case, the Waitangi Tribunal held hearings for the Ngāi Tahu claim from 1987 to 1989. In the end four separate reports were produced for Ngāi Tahu's claim. The first was released in 1991 and it covered the "nine tall trees", that is the eight major land purchases made between 1844 and 1864 and the restrictions on access to mahinga kai. The second and third addressed Ngāi Tahu's legal personality and sea fisheries claims and were produced in 1992. The final report covered the ancillary claims, which grew out of the "nine tall trees", and was released in $1995 .{ }^{49}$ The negotiations between Ngāi Tahu and the Crown covered all the grievances reported on by the Tribunal except for Ngāi Tahu's sea fisheries claims, which were subject to the 1992 PanMāori Fisheries settlement. In the case of the "nine tall trees", although the Tribunal did not uphold all of Ngāi Tahu's claims, it demonstrated that reserves had not been awarded and access to mahinga kai had been severely restricted to the detriment of the Ngāi Tahu people and recommended restitution.

The formation of the Waitangi Tribunal and the Court cases establishing the Treaty of Waitangi within New Zealand's legal framework were important in pushing the government to negotiate settlements with iwi, but the Tribunal could not negotiate for the Crown. The Waitangi Tribunal could largely only make recommendations. It was up to the government to negotiate and until the late 1980s it had not made any substantial efforts to begin negotiations. Until late 1988, the Labour government maintained that the settlements of the past for major Māori grievances were full and final and they would not be re-opened. Māori groups, the Tribunal, the Courts and internal factions within the Labour Party led by Koro

\footnotetext{
${ }^{49}$ Ngāi Tahu Report (Wellington: Waitangi Tribunal, 1991), 3 Vols; The Ngāi Tahu Claim: Supplementary Report on Legal Personality (Wellington: Waitangi Tribunal, 1991); Ngāi Tahu Sea Fisheries Report (Wellington: Waitangi Tribunal, 1992); Ngāi Tahu Ancillary Claims Report (Wellington: Waitangi Tribunal, 1995).
} 
Wetere and Geoffrey Palmer effectively served to change the government’s mind and pushed it to negotiate. ${ }^{50}$ These events prompted the Labour government to create the first official government policy unit charged directly with dealing with breaches of the Treaty of Waitangi, the Treaty of Waitangi Policy Unit (ToWPU). ${ }^{51}$ From the very beginning the Crown Law Office (CLO) would play a significant role in assisting ToWPU to develop Treaty policy advice to government and gradually other departments also began to play a part - Treasury (in relation to fiscal matters), the Department of Conservation (DoC), the Department of Prime Minister and Cabinet (DPMC) and Manatu Māori (later Te Puni Kōkiri). The ToWPU was originally established to solely provide policy advice to the government on Treaty of Waitangi issues but ToWPU officials were quickly drawn into involvement in direct negotiations.

Waikato-Tainui representatives had pushed for direct negotiations to address their historical claims throughout the second half of the 1980s because of the backlog of claims that were to be heard at the Waitangi Tribunal, and after much persistence the government agreed. In July and August 1989 the inaugural ToWPU Director, Alex Frame, a few ToWPU officials, a Treasury official and Crown Law representative travelled to the Waikato to engage in scoping negotiations with Waikato-Tainui. Despite the productive nature of the discussions, the Crown maintained that it would continue with its plans to sell its Coalcorp assets against Waikato-Tainui protests. A month after the scoping discussions the Tainui Māori Trust Board took its case to the Court of Appeal and requested an injunction on the sale of Coalcorp's assets. Waikato-Tainui's victory in the Coalcorp case pushed the

\footnotetext{
${ }^{50}$ Geoffrey Palmer, Reform: A Memoir (Wellington: Victoria University Press, 2013), 402-414; Ward, An Unsettled History, 30.

${ }^{51}$ Hill, Māori and State: Crown-Māori Relations in New Zealand/Aotearoa 1950-2000, 229.
} 
government to formally commence negotiations. ${ }^{52}$ Prime Minister Geoffrey Palmer announced at Te Awamaarahi Marae on 23 November 1989 that the Crown would begin formal negotiations with Waikato-Tainui. ${ }^{53}$

While participating in scoping negotiations with Waikato-Tainui, ToWPU also drafted the government's Principles for Crown Action on the Treaty of Waitangi in $1989 .{ }^{54}$ The government established five principles to govern Crown action on the Treaty: 1) The Principle of Kawanatanga or the Crown's right to govern; 2) The Principle of Rangatiratanga or the Māori right to self-management; 3) The Principle of Equality; 4) The Principle of Cooperation; and 5) The Principle of Redress. While the principle of redress was a novel approach by the Crown that was appreciated by Māori, there were other aspects of the Principles that came under criticism. Some Māori leaders felt that the principle of rangatiratanga was too limited and had undermined the findings on sovereignty made by the Waitangi Tribunal. ${ }^{55}$ The Crown sought to limit the principle of rangatiratanga to resources that Māori had already retained rather than resources that been sold, confiscated or otherwise obtained by the Crown through unscrupulous means. ${ }^{56}$

During this period the Waitangi Tribunal remained underfunded. ${ }^{57}$ When the Labour government was defeated by the generally conservative National Party in 1990 there were some fears that the minimal advances made at the end of the 1980s through the establishment of ToWPU, the Crown Forestry Rental Trust and amendments to legislation such as the State

\footnotetext{
${ }^{52}$ Hill, Māori and the State: Crown-Māori Relations in New Zealand/Aotearoa, 1950-2000, 253; Diamond, Māori Leaders Speak, 64.

${ }^{53}$ Robert Mahuta to Geoffrey Palmer, 23 January 1990, TC 30 Vol. 7, OTS archive.

${ }^{54}$ Orange, An Illustrated History of the Treaty of Waitangi, 198-199; Hill, Māori and the State: Crown-Māori Relations in New Zealand/Aotearoa, 1950-2000, 229; Durie, 188-189; Principles for Crown Action on the Treaty of Waitangi, Department of Justice, 1989.

55 Durie, Te Mana, Te Kawanatanga, 204-205.

56 Therese Crocker, "Introduction: Principles for Crown Action on the Treaty of Waitangi, 1989," Treaty of Waitangi Research Unit, Historical Document Series 6, Wellington, 2011, 8, 10-11.

${ }^{57}$ Hill, Māori and the State: Crown-Māori Relations in New Zealand/Aotearoa, 1950-2000, 253.
} 
Owned Enterprises Act would be reversed. The National Party had not traditionally been the political party associated with the promotion of legislation and policies that would help Māori generally. To the surprise of some, Justice Minister Douglas Graham along with the Prime Minister, Jim Bolger, pushed for a settlement process through direct negotiations.

Negotiations that had just begun with Waikato-Tainui in 1989 continued after a brief hiatus in 1991 with the National government and in the same year negotiations officially began with Ngāi Tahu. While there were regular monthly ad hoc meetings between the Crown and Waikato-Tainui and Ngāi Tahu negotiators respectively there was little advancement in either negotiation in the early 1990s. However, representatives from each party to negotiations were part of the pan-Māori fisheries negotiating team that concluded a \$170 million settlement with the Crown in $1992 .^{58}$

The Crown's negotiations with Waikato-Tainui and Ngāi Tahu were equally struggling around the 1993 election but by the end of 1994 Waikato-Tainui had signed an Agreement in Principle and Ngāi Tahu's negotiations had completely collapsed. Just prior to the settlement with Waikato-Tainui in late 1994, the Crown released its new formal Treaty negotiating policy document that built on the principles produced in 1989, The Crown's Proposals for the Settlement of Treaty of Waitangi Claims. ${ }^{59}$ While the policy addressed a number of issues related to the development of the Treaty settlement process, there was a prominent backlash from Māori groups to the unilateral fiscal limit of \$1 billion (1992

\footnotetext{
58 The pan-Māori fisheries settlement, often referred to as the Sealord deal, was signed on 23 September 1992. Coupled with the interim \$20 million settlement reached in 1989 with the Labour government, the Crown paid an additional $\$ 150$ million for a total of $\$ 170$ million and provided Māori with $20 \%$ of all quota for fisheries brought within the quota management system. Māori would then use this sum to enter into a joint venture agreement with Brierley Investments to purchase Sealord Products Limited. The Māori Fisheries Commission was renamed the Treaty of Waitangi Fisheries Commission and it was tasked with developing a method for the equitable distribution of the fisheries assets amongst the iwi across the country. After twelve difficult years of negotiation between Māori the Māori Fisheries Act was passed in 2004. Paul Moon, "The Creation of the 'Sealord Deal'," The Journal of the Polynesian Society, Vol. 107 No. 2 1998; Māori Fisheries Act 2004; Hill, Māori and the State: Crown-Māori Relations in New Zealand/Aotearoa, 1950-2000, 254-255.

${ }^{59}$ Crown Proposals for the Settlement of Treaty of Waitangi Claims, Department of Justice, 1994.
} 
dollars) placed on the total amount available for compensation-the "fiscal envelope." ${ }^{60}$ In addition to the fiscal cap, the Crown's proposals also did not recognise the possibility of Māori ownership of natural resources (except for pounamu or greenstone) and conservation land would only be returned in very limited and unique circumstances. Nonetheless, as Alan Ward has noted, they were a significant policy shift that consisted of much more than just the fiscal cap: "they acknowledged that historical injustices had occurred; accepted that the Crown had a duty to make reparation in settlements that were fair and sustainable, and removed the sense of grievance; and accepted that the resolution of claims must be consistent and equitable between groups.” ${ }^{61}$ In early 1995, the Treaty of Waitangi Policy Unit was renamed the Office of Treaty Settlements. Following Waikato-Tainui’s settlement Ngāi Tahu eventually recommenced negotiations with the Crown in mid-1996 and signed its own Agreement in Principle by October 1996 just prior to the 1996 election.

\section{Chapter structure}

Chapter 1 establishes the political framework of the negotiation process and will explore the commencement of each negotiation and the participants in each negotiation process. It will analyse the first major issue in each negotiation process, the return of the decommissioned Army Base at Hopuhopu to Waikato-Tainui, and the establishment of Te Rūnanga o Ngāi Tahu (TRONT). Both issues were emblematic of the Crown's control of the process, but also the Crown's focus on iwi-level leadership rather than the number of hapu (sub-tribes) who opposed the return of Hopuhopu to Waikato-Tainui and the formation of TRONT respectively. While Waikato-Tainui and Ngāi Tahu both sought to negotiate on the basis of strengthening their rangatiratanga, the Crown imposed early limits on the parameters

\footnotetext{
${ }^{60}$ Wira Gardiner, Return to Sender: What really happened at the fiscal envelope hui (Auckland: Reed Books, 1996); Ranginui Walker, Nga pepa a Ranginui: The Walker Papers (Auckland: Penguin, 1996).

${ }^{61}$ Alan Ward, An Unsettled History, 52.
} 
of the negotiations. Nan Seuffert has commented that rangatiratanga did not have a prominent place in Treaty settlement negotiations. ${ }^{62}$ In fact, rangatiratanga was central to WaikatoTainui and Ngāi Tahu’s aspirations for their Treaty settlement negotiations, and was prominent throughout the entire process. While the Treaty of Waitangi Policy Unit/Office of Treaty Settlements had the primary role in leading negotiations the Treasury, the Crown Law Office, the Department of Conservation, and the Department of Prime Minister and Cabinet also had prominent roles to play in Waikato-Tainui and Ngāi Tahu’s negotiating processes.

David McCan’s tribally-authorised general history of the Waikato-Tainui claim, Whatiwhatihoe, addressed in some detail the early negotiations with the Fourth Labour Government in the late 1980s but little on the majority of the negotiations that began with the National government in $1991 .^{63}$ Alex Frame, ToWPU Director during the Fourth Labour government, has also analysed his own role in the Crown's early negotiations with WaikatoTainui in 1989 and 1990. ${ }^{64}$ Waikato-Tainui chief negotiator Sir Robert Mahuta published two articles shortly after the negotiations were concluded which provided a brief account of the Waikato-Tainui negotiation process. ${ }^{65}$ Mahuta's introduction to Whatiwhatihoe and his interview with Paul Diamond in A Fire in Your Belly explored in more detail some of the political constraints under which Waikato-Tainui negotiated their settlement. ${ }^{66}$ Ngāi Tahu chief negotiator Sir Tipene O’Regan was also interviewed by Diamond for A Fire in Your Belly and similarly commented on the political limits of the negotiation process. O’Regan has

\footnotetext{
${ }^{62}$ Nan Seuffert, "Nation as Partnership: Law, 'Race’, and Gender in Aotearoa New Zealand's Treaty Settlements,” Law \& Society Review, Vol. 39, No. 3 (Sep. 2005), 509.

${ }^{63}$ David McCan, Whatiwhatihoe: The Waikato raupatu claim (Wellington: Huia, 2001).

${ }^{64}$ Alex Frame, "Raupatu Settlement - Legal Finality and Political Reality,” in Richard Hill and Richard Boast, eds. Raupatu: The Confiscation of Māori Land (Wellington: Victoria University Press, 2009).

${ }^{65}$ Robert Mahuta, "Tainui, Kīngitanga and Raupatu," in Margaret Wilson and Anna Yeatman (eds.) Justice \& Identity: Antipodean Practices (Wellington: Bridget Williams Books, 1995), 18-32; Robert Te Kotahi Mahuta, "Iwi Development and the Waikato-Tainui Experience,” in Paul Spoonley, Cluny Macpherson and David Pearson (eds.) Nga Patai: Racism and Ethnic Relations in Aotearoa/New Zealand (Palmerston North: Dunmore Press, 1996), 117-123;

${ }^{66}$ Sir Robert Mahuta, “Afterword,” in David McCan, Whatiwhatihoe: The Waikato raupatu claim (Wellington: Huia, 2001); “Sir Robert Mahuta” in Paul Diamond (ed.), A Fire in Your Belly (Wellington: Huia, 2003).
} 
also published on the political context in the period preceding the negotiations. O'Regan's contribution to The Bolger Years addressed the process of attempting to convince the Muldoon government of the validity of their claims, and in "Impact on Māori - A Ngāi Tahu perspective," the effect of the 1987 NZMC case on Ngāi Tahu. ${ }^{67}$ Similarly Ann Parsonson and Te Maire Tau have written overviews of the lead-up to the negotiation process and the final process itself but not much on the substantive negotiations which took place between 1991 and $1997 .^{68}$

On the Crown side there has been little produced about who negotiates and what roles different Departments have in the negotiation process although Dean Cowie has recently outlined the peoples and institutions that make up the general Treaty settlement process. ${ }^{69}$ Gavin Muirhead’s history of Landcorp provides some very frank insights into the tense politics which emerged between Landcorp and claimant groups such as Waikato-Tainui and Ngāi Tahu. ${ }^{70}$ Former Prime Minister Jim Bolger's introduction to The Bolger Years commented on the difficulty of handling opposition from the 'hierarchy of the National Party in the South Island' to the Ngāi Tahu settlement. ${ }^{71}$ The work of the Minister in Charge of Treaty of Waitangi Negotiations from 1991-1999, Sir Douglas Graham, addressed the difficulties of developing the Treaty settlement process when there was little acceptance from the public for reconciliation and compensation. Graham also provided more specific details

\footnotetext{
${ }^{67}$ Sir Tipene O’Regan, “Negotiating with Politicians,” in Margaret Clark (ed.), The Bolger Years (Palmerston North: Dunmore Press, 2008), 174-180; Sir Tipene O’Regan, "Impact on Māori - A Ngāi Tahu Perspective," in Jacinta Ruru (ed.), "In Good Faith" Symposium, Proceedings marking the $20^{\text {th }}$ anniversary of the Lands case (Dunedin: University of Otago and the Law Foundation NZ), 41-50; Carol Archie, Skin to Skin: Intimate, True Stories of Māori-Pākehā Relationships (Auckland: Penguin, 2005), 200-207; “Sir Tipene O’Regan,” in Paul Diamond (ed.), A Fire in Your Belly (Wellington: Huia, 2003).

${ }^{68}$ Ann Parsonson, "Ngāi Tahu - The Whale that Awoke: From Claim to Settlement (1960-1998)," in J. Cookson and G. Dunstall (eds.) Southern Capital, Christchurch: Towards a City Biography (Christchurch: Canterbury University Press, 2000), 248-276; Te Maire Tau, "Ngāi Tahu - From 'Better Be Dead and Out of the Way' to 'Be Seen and to Belong,' in in J. Cookson and G. Dunstall (eds.) Southern Capital, Christchurch: Towards a City Biography (Christchurch: Canterbury University Press, 2000), 222-247.

${ }^{69}$ Dean Cowie, 'The Treaty Settlement Process,' in Treaty of Waitangi Settlements, (eds. Nicola Wheen \& Janine Hayward).

${ }^{70}$ Gavin Muirhead, Footprints in the future (Wellington: Landcorp, 2009).

${ }^{71}$ Jim Bolger, 'Opening Remarks,' in Margaret Clark (ed.), The Bolger Years (Palmerston North: Dunmore Press, 2008), 14.
} 
regarding the National government's negotiations with both Waikato-Tainui and Ngāi Tahu from his own personal perspective in Trick or Treaty ${ }^{72}$

The problems concerning the representation of Māori negotiators have been written about fairly extensively. Evan Poata-Smith and Robert Joseph have explored the difficulties of representation and Treaty settlement negotiations. ${ }^{73}$ Ranginui Walker's concerns about the representatives who nearly signed the Whakatōhea Settlement in 1996 were explored in Walker's history of the Whakatōhea claim and in Paul Spoonley’s biography of Ranginui Walker, Mata Toa. Margaret Mutu has also published about her own experiences as the Chief Negotiator for Ngāti Kahu. The difficulties of representation were also investigated in some of the case studies in Dion Tuuta's Māori Experiences of the Direct Negotiation Process. ${ }^{74}$ Nearly every commentary similarly explored the Crown-imposed restrictions under which both iwi-level and hapū-level leaders struggled.

The political constraints of the negotiation process that were embodied in the tension between Waikato-Tainui and Ngāi Tahu’s assertion of rangatiratanga, and the Crown's right to govern, also extended to the economic dimension of each settlement. Chapter 2 will explore how Waikato-Tainui and Ngāi Tahu tried to convince the Crown of their respective financial losses, and how the economic parameters of each settlement were developed. At one level what Māori claimants sought as compensation is apparent within their specific claims to

\footnotetext{
${ }^{72}$ Douglas Graham, Trick or Treaty? (Wellington: Institute for Policy Studies, 1997); Sir Douglas Graham. “The Treaty and Treaty Negotiations,” in Margaret Clark’s The Bolger Years: 1990-1997 (Wellington: Dunmore Publishing, 2008).

${ }^{73}$ Evan TS Poata-Smith, "The Changing Contours of Māori Identity and the Treaty Settlement Process," in Janine Hayward and Nicola Wheen (eds.), The Waitangi Tribunal (Wellington: Bridget Williams Books, 2004), 168-183; Robert Joseph, 'Unsettling Treaty Settlements: Contemporary Māori Identity and Representation Challenges' in Treaty of Waitangi Settlements, (eds. Nicola Wheen \& Janine Hayward).

${ }^{74}$ Dion Tuuta, Māori Experiences of the Direct Negotiations Process (Wellington: Crown Forestry Rental Trust. 2003); Ranginui Walker, Opotiki-Mai-Tawhiti: Capital of Whakatohea (Auckland: Penguin, 2007); Paul Spoonley, Mata Toa: The Life and Times of Ranginui Walker (Auckland: Penguin, 2009); Margaret Mutu, "Recovering Fagin's Ill-gotten Gains: Settling Ngāti Kahu's Treaty of Waitangi Claims against the Crown" in Michael Belgrave, David Williams and Merata Kāwharu (eds.)Waitangi Revisited: Perspectives on the Treaty of Waitangi (Auckland: Oxford University Press, 2004).
} 
the Waitangi Tribunal, but their visions of specific settlement assets have not been explored. Debates regarding the quantification of historical loss were dominated by Treasury, with Ngāi Tahu spending particularly more of its resources and efforts early in their negotiations on the issue. This became connected to the development of a fiscal limit for Treaty settlements, the 'fiscal envelope,' in 1994. Waikato-Tainui engaged in discussions regarding the quantification of its loss when the Crown released its fiscal envelope policy in 1995.

The general financial and commercial dimensions of Treaty settlement negotiations have recently been addressed by Damian Stone, but not in any detail, and not specifically in relation to Waikato-Tainui and Ngāi Tahu's negotiations. ${ }^{75}$ In Richard Hill's history of Crown-Māori relations in the second half of the twentieth century he noted that the development of the Treaty settlement process in the early 1990s featured “much internal (and highly-contested) intra-state deliberation in which Treasury analyses featured large.”76 The connections between Treasury and the development of the Treaty settlement process have been briefly canvassed by Malcolm McKinnon, but are in need of some further elaboration in specific negotiations. ${ }^{77}$ A number of authors have briefly explored the Crown's "Proposals for Settlement of Treaty of Waitangi Claims,” which included the fiscal envelope. ${ }^{78}$ The Crown's unilateral control of the parameters for fiscal redress reflected its dominance of the process. Nonetheless the financial limits placed on all Treaty settlements made the Crown's goal of finality difficult. The issue of full and final within the government was largely driven

\footnotetext{
${ }^{75}$ Damian Stone, 'Financial and Commercial Dimensions of Settlement,' in NR Wheen and J Hayward (eds.) Treaty of Waitangi Settlements (Bridget Williams Books, 2012).

${ }^{76}$ Richard Hill, Māori and the State: Crown-Māori Relations in New Zealand/Aotearoa, 1950-2000 (Wellington: Victoria University Press, 2009), 262.

${ }^{77}$ Malcolm McKinnon, Treasury: The New Zealand Treasury, 1840-2000 (Auckland: Auckland University Press, 2003).

${ }^{78}$ Alan Ward, An Unsettled History: Treaty Claims in New Zealand Today, 52-54; Richard Hill Māori and the State: Crown-Māori Relations in New Zealand/Aotearoa, 1950-2000); Claudia Orange, Illustrated History of the Treaty of Waitangi, 217-219.

${ }^{78}$ King, The Penguin History of New Zealand, 499-502; Walker, Ka Whawhai Tonu Matou - Struggle Without End, 310.
} 
by the Crown Law Office but Treasury was also concerned about the finality of Treaty settlements because it wanted to limit the Crown's financial liabilities whereas the Crown Law Office was focused on the Crown's legal liabilities. The inaugural Director of ToWPU, Alex Frame, has recently published an article on the legal finality and the political reality of the negotiations and questioned whether finality can be achieved, much as Waikato-Tainui and Ngāi Tahu negotiators argued during their negotiations. ${ }^{79}$ Annie Mikaere and Wayne Rumbles similarly have expressed doubts about the government's interpretation of the finality of Treaty settlements in light of the small amount of compensation being offered. ${ }^{80}$ At the heart of the Crown's governance was the certainty sought from full and final agreements, but both Waikato-Tainui and Ngāi Tahu were able to assert their rangatiratanga and provide a challenge to the Crown's kawanatanga, or right to govern and forecast its finances accurately, by negotiating the inclusion of relativity clauses.

The political and economic limits within which Waikato-Tainui and Ngāi Tahu had to negotiate also influenced the return of land to each iwi. Chapter 3 will investigate the return of land to both iwi, the mechanisms developed to protect land from alienation, and the effect of third-parties on the Treaty settlement process. While the Crown controlled the overarching process under which lands were returned and protected from alienation, third parties played a significant role in which specific lands were returned. The economic parameters of settlements particularly limited the amount of land that would be returned to iwi, while the political context restricted the legal structure under which lands would be returned. WaikatoTainui especially sought the return of lands under a form of customary title that would in

\footnotetext{
${ }^{79}$ Alex Frame, "Raupatu Settlement - Legal Finality and Political Reality,” in Richard Hill and Richard Boast, (eds.) Raupatu: The Confiscation of Māori Land. Wellington: Victoria University Press, 2009.

${ }^{80}$ Wayne Rumbles, "Treaty of Waitangi Settlement Process: New Relationship or New Mask?" Compr(om)ising Postcolonialism(s): Challenging Narratives and Practices, edited by Dr Greg Ratcliffe (Dangaroo Press, 2002); Annie Mikaere, “Settlement of Treaty Claims: Full and Final, or Fatally Flawed?” New Zealand Universities Review, 17, 2 (1997) p. 451. A research paper by Louise Taylor has provided a useful initial analysis of the connection between the fiscal envelope process and the government's full and final policy: Louise Taylor, "The Fiscal envelope: a manifesto for finality,” LL.B. (Hons) Paper VUW, 1995.
} 
theory provide additional protection from possible future alienation. As Waikato-Tainui and Ngāi Tahu attempted to negotiate their own respective settlements, the Crown's over-arching privatisation policy impacted on the assets that would be available in any final agreement. The reforms of the public economy undertaken by Roger Douglas, Richard Prebble and others in the late 1980s continued in the early 1990s under a National government. WaikatoTainui and Ngāi Tahu tried to conserve the Crown's asset base to ensure that the best possible settlement would be available when negotiations finally ended. Both Ngāi Tahu and WaikatoTainui eventually developed mechanisms with the Crown in which surplus land that the Crown was considering for sale could be placed in a land-bank and transferred to the respective settling group upon settlement. Alan Ward, Claudia Orange and Damian Stone have explained the general land-banking process, but this chapter will explore the specific development of Waikato-Tainui and Ngāi Tahu's land-bank. ${ }^{81}$

Although the Crown controlled the wider context in which land was returned to iwi such as the land-banking process, the effect of third-parties (any individuals or groups other than the Māori claimant group and the Crown) was also influential on the return of lands. Third party conservation and sports recreation interests, and former owners of Crown land taken under the Public Works Act, delayed the return of some lands to Ngāi Tahu and Waikato-Tainui, and played a role in the exclusion of other lands from both settlements. The change generally from co-operation to confrontation between Māori protest movements and environmentalists has been explored by a number of authors. ${ }^{82}$ The interaction between third

\footnotetext{
${ }^{81}$ Orange, An Illustrated History of the Treaty of Waitangi, 227, 255; Ward, An Unsettled History, 36-37; Damian Stone, "Financial and Commercial Dimensions of Settlement," in Nicola Wheen \& Janine Hayward (eds.) Treaty of Waitangi Settlements (Wellington: Bridget Williams Books, 2012).

${ }^{82}$ David Young, Our Islands, Our Selves: A History of Conservation in New Zealand (Dunedin: Otago University Press, 2004); Keri Mills, “The Changing Relationship between Māori and Environmentalists in 1970s and 1980s New Zealand,” History Compass 7/3 (2009): 678-700.
} 
parties and the Waitangi Tribunal has also been investigated by Janine Hayward. ${ }^{83}$ However, there has been little work on the role of third parties in the Treaty settlement process, especially the role of former owners of Crown land under the Public Works Act, and the challenges they can present to effecting the return of land, and subsequently Waikato-Tainui and Ngāi Tahu's pursuit of rangatiratanga. ${ }^{84}$

Chapter 4 will analyse the formulation of Waikato-Tainui and Ngāi Tahu’s historical accounts and apologies within the context of the Māori pursuit of rangatiratanga and the Crown's defence of its sovereignty. As the negotiations began in the late 1980s with Waikato-Tainui, the Crown was focused solely on some form of compensation but little else. It became clear in the early scoping negotiations with Waikato-Tainui that some kind of apology and historical account was going to be necessary, that money alone and even the return of land would not be acceptable. Ngāi Tahu felt the same way and was addressing its historical account in a much more thorough fashion by engaging with the Waitangi Tribunal. Although there has been some commentary about the use of oral history within the Waitangi Tribunal process and the "historical frictions" and alleged "retrospective utopias" which marked the Tribunal process, there has been little discussion regarding the formulation of history within the Treaty settlement process and its importance to iwi such as Waikato-Tainui and Ngāi Tahu. ${ }^{85}$ Recently Maureen Hickey analysed the importance of Crown apologies in the general Treaty settlement process. The emphasis which Hickey places on the importance

\footnotetext{
83 Janine Hayward, “Three’s a Crowd?: The Treaty of Waitangi, the Waitangi Tribunal, and Third Parties” New Zealand Universities Law Review, 20(2): 239-251 (2002).

${ }^{84}$ One exception is Ben White’s 1994 Master of Resource Management thesis, "Sites of Contestation: Perceptions of Wilderness in the Context of Treaty Claim Settlements,” Lincoln University.

${ }^{85}$ W.H. Oliver, Claims to the Waitangi Tribunal (Wellington: Department of Justice, 1991); Miranda Johnson, "Honest acts and dangerous supplements: Indigenous oral history and historical practice in settler societies," Postcolonial Studies, Vol. 8, No. 3, 261-276; Belgrave, Historical Frictions; Waitangi Revisited: Belgrave?; McAloon, Jim. "By Which Standards? History and the Waitangi Tribunal," New Zealand Journal of History, 40, 2 (2006), 194-213; Giselle Byrnes, "By Which Standards? History and the Waitangi Tribunal: A Reply," New Zealand Journal of History, 40, 2 (2006), 214-229; W.H. Oliver, “A Reply To Jim McAloon,” New Zealand Journal of History, 41, 1 (2007), 83-87.
} 
of the apology to the settling group is reflected in the experiences of Waikato-Tainui and Ngāi Tahu negotiators and claimants in their own negotiations. ${ }^{86}$ Julie Bellingham’s excellent M.A thesis analysed the development of historical accounts and apologies from a historiographical perspective, but it was limited in its use of Crown and Māori claimant sources. ${ }^{87}$ A particularly useful article regarding the "politicisation of the past" and the expressly political histories that emerge from Crown and Māori claimant settlement negotiations was recently co-authored by Richard Hill. ${ }^{88}$

The four reports produced by the Waitangi Tribunal from 1991-1995 (and the many other research reports produced by Ngāi Tahu and the Crown for the hearing), the work of Ngāi Tahu historians such as Sir Tipene O’Regan and Te Maire Tau, and Ngāi Tahu affiliated historians such as Harry Evison, has resulted in an extensively comprehensive history of Ngāi Tahu's relations with the Crown. ${ }^{89}$ Waikato-Tainui's history related to the wars of the 1860 s had been addressed in greater detail over the years by historians. ${ }^{90}$ Claudia Orange has commented that the acceptance of the injustice of Waikato-Tainui's historical grievances allowed for negotiations to get underway quicker than Ngāi Tahu. While the notion of progress can always be relative, Waikato-Tainui did not perceive that their negotiations

\footnotetext{
${ }^{86}$ Maureen Hickey, “Crown Apologies,” in Janine Hayward \& Nicola R. Wheen (eds.), Treaty of Waitangi Settlements (Wellington: BWB, 2012), 69-84.

${ }^{87}$ Julie Bellingham, "The Office of Treaty Settlements and Treaty history : an historiographical study of the historical accounts, acknowledgements and apologies written by the Crown, 1992 to 2003,” M.A. Thesis: VUW, 2006.

${ }^{88}$ Richard Hill and Brigitte Bonisch-Brednich, "Politicizing the Past: Indigenous Scholarship and Crown-Māori Reparations Processes in New Zealand.” Social and Legal Studies, (2007), 163-181.

${ }^{89}$ Ngāi Tahu Report (Wellington: Waitangi Tribunal, 1991), 3 Vols; The Ngāi Tahu Claim: Supplementary Report on Legal Personality (Wellington: Waitangi Tribunal, 1991); Ngāi Tahu Sea Fisheries Report (Wellington: Waitangi Tribunal, 1992); Ngāi Tahu Ancillary Claims Report (Wellington: Waitangi Tribunal, 1995); Tipene O’Regan, “The Ngāi Tahu Claim," in I.H. Kawharu (ed.), Waitangi: Māori and Pākehā perspectives of the Treaty of Waitangi (Auckland: Oxford University Press, 1989); Harry Evison, The Long Dispute, European Colonisation and Māori Land Rights in Southern New Zealand (Christchurch: Canterbury University Press, 1997).

${ }^{90}$ Michael King, Te Puea: A Life (Auckland, Penguin, 1977); Pei Te Hurunui Jones, "Māori Kings" in The Māori people in the nineteen-sixties (ed.) Erik Schwimmer (Auckland: Hurst, 1968); Belich, The New Zealand Wars.
} 
proceeded “swiftly” as Orange claims. ${ }^{91}$ Waikato-Tainui’s grievances were not accepted by the Crown until officials pushed for its acceptance. Waikato-Tainui engaged in direct negotiations, although they did try to return to the Tribunal when negotiations were in hiatus. In that sense although Waikato-Tainui’s claim was accepted to a greater degree than Ngāi Tahu’s, hence their alleged early willingness to negotiate, there was more known about Ngāi Tahu's claim by the time each began their negotiations. Before turning to the sources analysed for this investigation, the contents of Waikato-Tainui and Ngai Tahu's settlements will be detailed.

\section{Waikato-Tainui and Ngāi Tahu's settlements}

Waikato-Tainui and the Crown signed an Agreement in Principle on 21 December 1994 and a Deed of Settlement six months later on 22 May 1995. The Waikato-Tainui settlement was nominally worth \$170 million. This included approximately \$100 million worth of land from various government departments in the Waikato-Tainui raupatu area, \$65 million in cash with which to purchase further lands, approximately \$3 million covered the cost of the decommissioned Te Rapa Airbase (the decommissioned military base at Hopuhopu was transferred at zero value to the overall quantum), and \$2 million for funding the negotiations. The cash that Waikato-Tainui received was coupled with the Right of First Refusal (RFR), which provided Waikato-Tainui with the right to be the first to purchase or refuse Crown properties as they became available for privatisation in their region. ${ }^{92}$ WaikatoTainui negotiators also negotiated interest payments that added up to approximately $\$ 20$ million. Interest was paid to Waikato-Tainui from the date their Heads of Agreement was signed to the date their full quantum was paid at a rate of $8.8716 \%$ approximately four and a

\footnotetext{
${ }^{91}$ Orange, The Illustrated History of the Treaty of Waitangi, 221.

${ }^{92}$ Waikato-Tainui Raupatu Deed of Settlement, 22 May 1995, Sections 4 and 10.
} 
half years later. ${ }^{93}$ While Waikato-Tainui wanted to have Department of Conservation land included in its settlement or at least co-management arrangements for land in the WaikatoTainui raupatu region, there was substantial opposition from both the Department of Conservation and the conservation movement outside of government. Waikato-Tainui did manage to have a permanent seat on the Waikato Conservation Board included as a part of its settlement. At nearly the exact same time that the Crown agreed to a settlement with Waikato-Tainui in late 1994, the government established that the fiscal limit for settlements was a total of $\$ 1$ billion. Since they were the first major iwi to settle its historical land based (raupatu) grievances Waikato-Tainui negotiators remained adamant that the settlement include a relativity clause — the clause provides that when the total value of historical Treaty settlements exceeds \$1 billion in 1994 present value terms, Waikato-Tainui may request further payments from the Crown to ensure that the real value of its settlement remains at $17 \%$ of total settlements. ${ }^{94}$

Ngāi Tahu and the Crown signed an Agreement in Principle on 5 October 1996 and a Deed of Settlement was signed a year later on 21 November 1997. Ngāi Tahu’s settlement was also nominally worth $\$ 170$ million but its base value was marginally less since it was paid at the value of the New Zealand dollar in October 1996 while Waikato-Tainui's settlement was paid at the value of the dollar in December 1994. Ngāi Tahu also negotiated the inclusion of interest payments so that interest would accrue from the date of the signing of the Heads of Agreement until their full compensation of \$170 million was paid, nearly five years later at the rate of $8.8716 \% .{ }^{95} \mathrm{Ngāi}$ Tahu's settlement was coupled with a RFR and in addition Ngāi Tahu was also able to negotiate a Deferred Selection Process (DSP) which allowed Ngāi Tahu to select assets for purchase which the Crown did not originally want to

\footnotetext{
${ }^{93}$ Waikato-Tainui Raupatu Deed of Settlement, 22 May 1995, Section 11.

${ }^{94}$ Waikato-Tainui Raupatu Deed of Settlement, 22 May 1995, Section 19.9 and Attachment 9.

${ }^{95}$ Ngāi Tahu Deed of Settlement, 21 November 1997, Section 2.6.
} 
sell, unlike the RFR which was triggered only when the Crown wanted to dispose of assets. Some properties taken under the DSP were still required for use by the Crown, for example the Christchurch and Queenstown Police Stations, and they provided a cash flow for Ngāi Tahu. ${ }^{96}$ Additionally Ngāi Tahu was able to negotiate for a provision that allowed them to use an additional $\$ 80$ million of their own money on top of the $\$ 170$ million quantum to purchase properties under the DSP. Ngāi Tahu also negotiated the inclusion of a relativity clause that was only marginally less than the $17 \%$ achieved by Waikato-Tainui, $16.1 \%$, but their interest payments were slightly larger. ${ }^{97}$

Unlike Waikato-Tainui’s settlement, which only related to their historical grievances related to war and the confiscation of land, and not their claims to the Waikato River and West Coast Harbours, Ngāi Tahu’s settlement encompassed all of their claims. ${ }^{98}$ Ngāi Tahu was able to negotiate provisions in their settlement for a guaranteed Ngāi Tahu seat on every Regional Conservation Board in its region as well as a dedicated seat on the New Zealand Conservation Authority. The Crown agreed to gift the conservation aspects of the Ngāi Tahu settlement so their monetary value would not be subtracted from the $\$ 170$ million base quantum. In the area around the bottom of the South Island near Stewart Island (Rakiura), Ngāi Tahu was able to secure the freehold title unencumbered with a marginal strip or Queen's chain for the Crown Titi Islands and Rarotoka Island. At Codfish Island (Whenua Hou) Ngāi Tahu negotiated co-management arrangements that provided Ngāi Tahu with a

\footnotetext{
${ }^{96}$ Sir Tipene O’Regan has described the RFR process as an inverse of the Crown's pre-emption policy in which only the Crown could purchase from Ngāi Tahu. "We could only sell to the Crown. Well, if the Crown wants to sell, it can only sell to us!” Sir Tipene O’Regan, “Te Kereme: The Claim, Lecture Two,” Macmillan Brown Lecture Series 1998, MB archive.

${ }^{97}$ Ngāi Tahu Deed of Settlement, 21 November 1997, Sections 5, 9 and 18; 'The Settlement,' $<$ http://www.ngaitahu.iwi.nz/About-Ngai-Tahu/Settlement/>, accessed 27 April 2013.

${ }^{98}$ Waikato Raupatu Claims Settlement Act 1995, Section 8; $\backslash$ Ngāi Tahu Deed of Settlement, 21 November 1997, Section 1.2.
} 
significant role in the management of the island. The beds of Lakes Waihora, Mahinapua and Muriwai were also returned. ${ }^{99}$

On the West Coast of the South Island Ngāi Tahu sought further control of the Arahura River area where most of the country's pounamu (greenstone) was located. As part of the settlement all of the country's pounamu was transferred to Ngāi Tahu ownership. The bed of the Arahura River had been vested in the Mawhera Incorporation, a Ngāi Tahu Māori landowners trust, in 1976, but its boundaries remained unsurveyed and were only defined by natural features. The Ngāi Tahu settlement allowed for the creation of an historic reserve known as the Waitaiki Historic Reserve in the upper catchment of the Arahura Valley, which was vested at no cost in the Mawhera Incorporation. Public access would be protected and the Department of Conservation would continue to own all the huts and bridges in the area but the Mawhera Incorporation would be able to exercise effective control and management over its lands in the area. Ngāi Tahu was able to acquire Aoraki (Mount Cook) as a part of its settlement but the Mountain was to be immediately gifted back to the nation. ${ }^{100} \mathrm{Ngāi}$ Tahu also negotiated for the provision of 72 nohoanga entitlements, which are seasonal campsites reserved exclusively for Ngāi Tahu for over half of the year. Finally there were a number of individual ancillary Ngāi Tahu claims that were also settled by the return of individual parcels of land that were not vested in Ngāi Tahu as a tribal entity, but in the Ngāi Tahu individuals themselves. These were approximately 50 discrete sites around the South Island. $^{101}$

\footnotetext{
${ }^{99}$ Ngāi Tahu Deed of Settlement, 21 November 1997, Sections 11 and 13; 'The Settlement,' $<$ http://www.ngaitahu.iwi.nz/About-Ngai-Tahu/Settlement/>, accessed 4 May 2013.

${ }^{100}$ Ngāi Tahu have not yet formally exercised their right to receive back Aoraki. Ngāi Tahu also negotiated a number of Statutory Acknowledgments, Deeds of Recognition and Topuni Reserves over various natural sites around their rohe: Ngāi Tahu Deed of Settlement, 21 November 1997, Section 12.

${ }^{101}$ Ngāi Tahu Deed of Settlement, 21 November 1997, Sections 3, 13 and 14.
} 
Waikato-Tainui and Ngāi Tahu’s settlements would establish the benchmarks by which most future settlements would be negotiated over the following decades and continue today. They developed out of what has been described as the modern Treaty of Waitangi Claims process and were one product of what has been termed the 'Māori Renaissance.' 102 The agreements were far from what Māori groups had wanted but they were nonetheless significant settlements. They were compromises aimed at achieving a measure of reconciliation and some closure for those that been carrying historical grievances from generation to generation.

\section{Sources}

This thesis was enabled by the Office of Treaty Settlements, which provided access to its archives. These sources were supplemented by the collections held by Te Rūnanga o Ngāi Tahu and the Waikato-Tainui College of Research and Development. ${ }^{103}$ In addition, Sir Douglas Graham, the Minister of Treaty Negotiations for most of the 1990s, provided unrestricted access to his own personal files held at Archives New Zealand, Wellington. ${ }^{104}$ Throughout the thesis nearly all Crown officials are unidentified. Officials do what their job description requires them to do-give advice to the Minister and the government and once decisions are made by Cabinet, implement those decisions. Any letter, memorandum or paper that was signed out to the Minister went through many hands and had managerial input and reflected an institutional view not the personal views of the authors which is one of the

\footnotetext{
102 Therese Crocker, “Introduction: Principles for Crown Action on the Treaty of Waitangi, 1989,” Treaty of Waitangi Research Unit, Historical Document Series 6, Wellington, 2011, 5; James Belich, Paradise Reforged: A History of the New Zealanders from the 1880s to the Year 2000 (Auckland: Penguin, 2001), 466-487.

${ }^{103}$ Te Runanga o Ngāi Tahu archives were held at their former Central Christchurch offices on Hereford Street and at the Macmillan Brown Library at the University of Canterbury. The Waikato-College of Research and Development is located at Hopuhopu near Ngaruawahia.

${ }^{104}$ The Crown, the Waikato-Tainui College of Research and Development and Te Rūnanga o Ngāi Tahu all required that I sign a confidentiality agreement before accessing their archives. In each agreement, every party required that I send them a draft for comment and the Crown specifically requested anonymity for all of its officials. While their comments were useful and influenced certain aspects of this thesis, I have retained complete editorial control.
} 
reasons that almost all Crown officials have remained anonymous. Ministers, Secretaries of Ministries, principal negotiators and Waikato-Tainui and Ngāi Tahu advisors (where they have agreed to be named) have not been kept anonymous. Generally documents were split into approximately four different formats: memoranda, briefing and Cabinet papers, correspondence, and minutes of meetings. These primary sources were supplemented by contemporary newspapers such as the Evening Post, Waikato Times, New Zealand Herald, the Dominion and The Press and periodicals such as The Listener and North and South. While the focus of this investigation was not television current affairs and news programs, the TVNZ Archives at Avalon Studios, Lower Hutt as well as the NZ Film Archive in Wellington also had many relevant primary sources which informed this analysis.

A rather crucial set of OTS files related to the Waikato-Tainui negotiations from January 1993 to September 1994 have been lost, but I have been able to fill this gap with sources from Waikato-Tainui’s archives, Sir Douglas Graham’s archives and interviews with surviving players. Many key players in the development of both Waikato-Tainui and Ngāi Tahu’s negotiations are still alive and this primarily document-based analysis has been supplemented by a series of interviews with Crown and Māori negotiators and advisors. I interviewed both Crown officials and negotiators and advisors for Waikato-Tainui and Ngāi Tahu:

- Sir Douglas Graham (The Principal Crown Negotiator for both negotiations)

- Sir Tipene O’Regan (Principal Ngāi Tahu Negotiator)

- Denese Henare (Senior Legal Advisor Waikato-Tainui)

- Brent Wheeler (Financial Advisor Waikato-Tainui)

- Te Maire Tau (Historical Advisor Ngāi Tahu) 
- Sid Ashton (Ngāi Tahu Māori Trust Board Secretary and Te Rūnanga o Ngāi Tahu CEO)

- Richard Meade (Financial Advisor Ngāi Tahu)

- Shane Solomon (Legal and Historical Advisor Waikato-Tainui)

- Anake Goodall (Advisor and Claims Manager Ngāi Tahu)

- Nanaia Mahuta (daughter of Principal Waikato-Tainui Negotiator Sir Robert Mahuta)

- Alex Frame (ToWPU Director)

- 4 ToWPU officials and a CLO official.

While the interviews required written consent from the interviewees they were not taperecorded or transcribed as this thesis was not meant to be based primarily on oral histories. Where references are made to interviews they are sourced from notes that I took during the interviews and double checked with the interviewees. The interviews were conducted to provide context for the primary document-based analysis and for filling in gaps such as those noted above.

For the official monthly meetings, minutes were produced by both the Crown and the respective claimant negotiating group. These were subject to revisions from both sides and an agreed set of minutes were produced for each meeting. This set of minutes was the Crown's official record of the meeting. Waikato-Tainui and Ngāi Tahu respectively also produced their own record of the minutes of the meeting. These were not subject to revision by the Crown and were often not shared with the Crown unless there was a substantial disagreement over a negotiation issue or over the accuracy of the Crown's version of the meeting. The Crown's minutes of meetings were always shorter than either Waikato-Tainui or Ngāi Tahu's versions of the meetings. Sometimes the Crown could use just one page to provide minutes 
for the meeting whereas either Waikato-Tainui or Ngāi Tahu could use up to ten pages for the exact same meeting.

At individual meetings between Graham and Waikato-Tainui Principal Negotiator Robert Mahuta there would be no record of the meeting from the Crown or from Graham himself. Graham's archive was a much more official collection that consisted of barely any of the filenotes that Mahuta and O’Regan kept. O’Regan and Mahuta both kept copious notes of phone calls and meetings. One of Mahuta’s advisors, Shane Solomon, was a prolific notetaker and cartoonist. One large section of the Ngāi Tahu archive formerly held in central Christchurch was exclusively the files of the long-serving former Secretary of the Ngāi Tahu Māori Trust Board and CEO early in Te Rūnanga o Ngāi Tahu’s history, Sid Ashton. Their archives provide a singular view of certain meetings because there was no evidence of the meeting from the Crown archive. Mahuta, Solomon and O’Regan were scathing at times of the Crown in their own file notes but Ashton could be just as angry. One of his filenotes from a mid-1996 meeting had in large hand-written bold letters: "We must remember the CROWN is the enemy." 105 The singular point of view provided by such a perspective could potentially influence the value of the source since the only information had come from that one source, but the same concern could apply to the perspectives of Crown officials.

In general, larger meetings would have more sources of information and could be corroborated in better ways. Sometimes there would be numerous different accounts of one large meeting from both the Crown and either Waikato-Tainui or Ngāi Tahu. This would not often be the case as the best case scenario was at least one version from the Crown and one from Waikato-Tainui or Ngāi Tahu. Much larger meetings that involved public consultation would have publications such as newspapers producing their own accounts as well as video

\footnotetext{
${ }^{105}$ Sid Ashton, handwritten notes, 3-4 April 1996, Vhi 49(l), TRONT archive.
} 
accounts of the signing. These types of meetings provided the best circumstances for the proliferation of sources. The changes that could be made to meeting minutes were generally a result of compromise but at least one of the early minutes in the Waikato-Tainui negotiations was altered unilaterally. When Labour Minister of Justice Bill Jeffries was involved in the negotiations in 1990, the Crown's own copy of the March meeting minutes has written on the first page that "these were altered by the Minister [Jeffries]." ${ }^{\text {"106 }}$ It was unclear exactly which alterations had been made but luckily for that specific meeting there was also a WaikatoTainui version of the meeting.

It is understandable why the Crown would want in some cases to provide as little detail as possible in its minutes, for confidentiality purposes. The minutes could be subject to Official Information Act requests. The Crown might want to preserve its negotiating position and tactics for future negotiations. The production of sources in contemporary history such as the Waikato-Tainui and Ngāi Tahu negotiations is intensely political for both sides. WaikatoTainui and Ngāi Tahu on the other hand provided an almost intimate level of detail which was also understandable from their own positions, having to bring up previous Crown comments and promises of action that were not followed through. While it is clear that there are many other sources of information other than minutes, such as filenotes and memoranda, in the case of these negotiations the accuracy of the minutes was important for not only future historians but the negotiations themselves. The minutes needed to be precise for the sake of the Crown's institutional knowledge as staff turnover is inevitable in any workplace and was heightened at the time at ToWPU/OTS. Waikato-Tainui and Ngāi Tahu on the other hand had a deep archive of institutional knowledge across the different strata from the principal negotiators at the top, such as Mahuta and O’Regan, down to advisors. This documented

\footnotetext{
${ }^{106} 5$ March 1990 meeting (Crown version), TC 30 Vol. 7, OTS archive.
} 
institutional knowledge was extremely beneficial to both Waikato-Tainui and Ngāi Tahu. Looking at it from this view the Crown had to rely overtly on its own recent oral histories while Waikato-Tainui and Ngāi Tahu excelled at documenting their negotiating experience. Issues surrounding memory and Treaty settlements will be very important moving into the future. Finality is often an important mark of settlements, people always ask: will this be the end? Can we move on? For a settlement to endure it must not only provide economic and political stimuli, but the journey to the settlement also must remain etched in the memory of not only the generation that negotiated it but those following it. In that way Waikato-Tainui and Ngāi Tahu's own archives will be especially valuable for justifying the settlement to future generations in case doubts develop.

Waikato-Tainui and Ngāi Tahu’s Treaty settlement negotiations with the Crown were significant for each party that was involved. Ngāi Tahu, Waikato-Tainui and the Crown underwent some significant changes by the end of their negotiations. Infused with economic and political resources, Ngāi Tahu and Waikato-Tainui were no longer operating under the old Māori Trust Board structure and each organisation developed its own governing arrangements. While the Crown limited the extent of rangatiratanga there were still prominent gains that were made-especially by Ngāi Tahu which resolutely sought and achieved legislative recognition to govern its own people to a certain extent. Both groups negotiated important historical accounts and apologies from the Crown and settlements that were less than full and final. The precedents of the Waikato-Tainui and Ngāi Tahu settlements established the benchmarks that would govern every settlement that followed. The Crown also had changed significantly since the negotiations with Waikato-Tainui and Ngāi Tahu had begun. The Crown was now committed to negotiating Treaty settlements with Māori groups around the country. Although the Crown guarded its own sovereignty and its 
right to govern it also provided some significant concessions to Waikato-Tainui and Ngāi Tahu. The Crown very slightly loosened its grip on power on issues such as finality and management of conservation areas amongst others. These Treaty settlement negotiations started the ball rolling and while they were far from perfect from the view of any participant, as a process of reconciliation they have changed New Zealand forever. 


\section{Chapter 1: The Politics of Negotiations: kawanatanga and rangatiratanga}

This chapter will explore the Waikato-Tainui and Ngāi Tahu negotiation process from the Fourth Labour government in the late 1980s to just before the first substantial settlement offers were made to Waikato-Tainui in 1994 and Ngāi Tahu in 1996 by the Fourth National government. It will argue that the Crown framed the political parameters of the negotiations by challenging Waikato-Tainui and Ngāi Tahu attempts to re-assert rangatiratanga, as well as hapū who challenged the iwi-driven process established by the Crown. Although each iwi approached rangatiratanga within their negotiations in different ways, there was a shared desire to challenge the Crown's governing power to the fullest extent possible.

Although the negotiations for the settlement of Waikato-Tainui and Ngāi Tahu's Treaty claims began at approximately the same time, both groups arrived at negotiations through different paths. While Ngāi Tahu had their claims heard by the Waitangi Tribunal process from 1987 to 1989, Waikato-Tainui sought to engage in direct negotiations with the Crown. Waikato-Tainui was the first group to enter direct negotiations. This occurred at a time when, under the Fourth Labour government, the emerging Crown policy for settling Treaty claims sought to reaffirm the position of the Crown according to existing understandings of kawanatanga as the sovereign authority. Māori would have their rangatiratanga restored as a form of iwi self-management. Negotiations between the Crown and Waikato-Tainui began in mid-1989 with three preliminary scoping sessions only months before the Coalcorp case was heard in the Court of Appeal. Following Waikato-Tainui's victory in Court, the Crown was directed to commence formal negotiations which began in early 1990. These negotiations largely focused on fulfilling the spirit and intent of the 1946 Waikato Maniapoto Claims Settlement Act, but within the context of a return of some lands to Waikato-Tainui. When the Labour government made a financially limited offer before the 
1990 election, Waikato-Tainui negotiators rejected it. After a hiatus of approximately a year, Waikato-Tainui resumed negotiations, this time with the newly elected National government under the leadership of Prime Minister Jim Bolger in November 1991. Negotiations with Ngāi Tahu began in September 1991, eight months after the release of the Tribunal's report.

The second and final phase of Waikato-Tainui's negotiations and the first phase of Ngāi Tahu’s negotiations, from 1991-1994, ran parallel to each other as both were eager to finalise their settlement. While both experienced the frustrations of dealing with a government that was largely developing policy ad hoc, if a full policy had been put in place it would have been viewed as a decree from above or involved years of consultation. WaikatoTainui and Ngāi Tahu also met resistance to key elements of the redress they sought. A central point of disagreement that was common with both negotiations was the extent to which Māori autonomy - rangatiratanga - would be acknowledged within the settlement. Waikato-Tainui and Ngāi Tahu framed their negotiations with the Crown as an attempt to reassert rangatiratanga. The Crown's view was still framed in some ways in the mindset of the 1940s, although there were some significant differences. As in the 1940s, redress would be provided in the form of money, but issues regarding the recognition of autonomy were not negotiable. The 1989 Principles for Crown Action, as limited as they may have been from the view of some activists and academics, were different from the policies of the 1940s since they included the return of land.

From the earliest point in their negotiations, Ngāi Tahu sought a legal personality as recognition of their rangatiratanga. ${ }^{107}$ This would replace the Ngāi Tahu Māori Trust Board structure which they viewed as impinging on their rangatiratanga because of the limited control of funds and assets that was inherent in the system. The Trust Board was ultimately

\footnotetext{
${ }^{107}$ Alexandra Emma-Jane Highman, “Te Iwi of Ngāi Tahu: An Examination of Ngāi Tahu ’s Approach to, and Internal Expression of, Tino Rangātiratanga,” M.A Thesis, University of Canterbury, 1997.
} 
accountable to the Minister of Māori Affairs, rather than to the Ngāi Tahu people. Negotiations with the Crown Law Office and the Law Commission over the use of the term "rangatiratanga" extended over a year before the Te Rūnanga o Ngāi Tahu Bill was introduced to Parliament in 1993. Substantial internal opposition from some hapū affiliated with Ngāi Tahu and prominent opponents of the Ngāi Tahu negotiating team (including members of Parliament) delayed the legislation. These disagreements reflected the differing views towards the role of rangatiratanga in Ngāi Tahu's governing structure. Eventually, in 1996, the legislation was finally passed. ${ }^{108}$

Treaty settlement negotiations have been described by Robert Joseph as having the effect of 'unsettling Māori communities' due to the prescriptive rules on mandate and representation applied by the Crown. Joseph correctly points out that many Treaty settlements negotiated in New Zealand have resulted in representation challenges in either the Waitangi Tribunal or the courts. While the Crown's focus on 'large natural groupings' allows for a quicker settlement process, Joseph notes, it significantly constrains Māori groups that operate more at the whanau and hapū level. ${ }^{109}$ During Waikato-Tainui and Ngāi Tahu's negotiations the 'large natural groupings' policy had not been formally established, but the Crown was clear that it would only negotiate with the leaders of major iwi in the case of Waikato-Tainui and Ngāi Tahu. Other claimants negotiated much more specific small scale settlements during the early 1990s, but these were small and discrete claims. ${ }^{110}$ In the case of Waikato-Tainui and Ngāi Tahu, iwi negotiators did not go through formal mandating processes that exist today. The named claimants for both iwi, Robert Mahuta for WaikatoTainui and Henare Rakiihia Tau Senior for Ngāi Tahu, were intimately involved in the

\footnotetext{
${ }^{108}$ Te Runanga o Ngāi Tahu Act 1996.

${ }^{109}$ Robert Joseph, 'Unsettling Treaty Settlements: Contemporary Māori Identity and Representation Challenges' in Treaty of Waitangi Settlements, (eds. Nicola Wheen \& Janine Hayward).
} 
negotiation process. Throughout the negotiations hui-ā-iwi were held by both Ngāi Tahu and Waikato-Tainui to confirm their negotiating status. There was nonetheless opposition from hapū within both iwi who wanted to negotiate hapū settlements themselves. The political nature of Treaty settlements ensured that the Crown and iwi-level leadership would dominate the parameters of the process. Eventually there was considerable support for the iwi-level approach advocated by the Crown from many within both Waikato-Tainui and Ngāi Tahu. 


\section{Part I: Waikato-Tainui's negotiations with the Fourth Labour government and Fourth National government}

\section{Early attempts at negotiation and the 1989 Coalcorp case}

In late 1986 Robert Mahuta on behalf of the Tainui Māori Trust Board (TMTB) and Nga Marae Toopu (a group of marae aligned with the Kīngitanga), and 33 hapū aligned to the TMTB, submitted a claim to the Waitangi Tribunal regarding grievances related to the confiscation of Waikato lands by Orders in Council of 1865. Mahuta was the adopted son of the fourth Māori King, Koroki, and the sister of Queen Te Atairangikaahu or Te Arikinui. Te Arikinui succeeded her father, King Koroki, in 1966. Mahuta was also the Chairman of the Tainui Māori Trust Board. ${ }^{111}$ Waikato-Tainui sought the return of as much Crown land as possible to compensate the iwi for the confiscation of land. Their key negotiating principle remained "i riro whenua atu me hoki whenua mai/ as land was taken so land must be returned” and thus the focus of their claim was the return of land. They submitted an amended claim to include claims to the Waikato River and harbours around Kawhia and Raglan in March 1987, and a claim which specifically sought to halt the pending alienation of State-Owned Enterprises land. ${ }^{112}$

At the same time, the New Zealand Māori Council (NZMC) brought proceedings against the Crown to review the State-Owned Enterprises (SOE) Act 1986. The NZMC wanted to clarify the meaning and effect of sections 9 and 27 which provided some safeguards for Māori claims to SOE lands and assets. In mid-1987 the Court of Appeal found in favour of the NZMC that sections 9 and 27 had real force, and directed the Crown to negotiate with Māori to develop more effective safeguards. By the end of 1987 an agreement

\footnotetext{
${ }^{111}$ Paul Diamond, When Māori Leaders Speak, 67.

112 Robert Mahuta, TMTB \& Nga Marae Toopu, WAI 30 (1986-1987), TC30 Vol. 2, OTS archive.
} 
was reached which resulted in the Treaty of Waitangi (State Enterprises) Act $1988 .{ }^{113}$ It introduced a protection mechanism, a memorial on the land title, to protect against the disposal of Crown assets that were still the subject of Treaty claims. ${ }^{114}$ Waikato-Tainui had considered bringing their own separate case to Court in 1987 at the same time as the NZMC to prevent the alienation of SOE lands in the Waikato-Tainui region, but they were given an oral undertaking by the Solicitor-General in March of 1987 that the government would halt the sale of all surplus assets in the Waikato region. ${ }^{115}$

In early 1988 Mahuta wrote to the Minister of State-Owned Enterprises, Richard Prebble, requesting that the March 1987 oral undertaking given by the Solicitor-General be put into writing. Prebble denied that any promises had ever been given and that further future amendments to the SOE legislation would address any issues Mahuta had. While there was nothing mentioned about a definite date for a future meeting, Prebble agreed that the Crown would eventually seek to enter into negotiations with Waikato-Tainui. ${ }^{116}$ While negotiations remained on hold, at the end of 1988 Robert Mahuta, Waikato-Tainui legal advisor Denese Henare and TMTB member Hare Puke continued to send letters to Prebble's successor, Minister of State-Owned Enterprises Stan Rodger, requesting that the sale of Crown properties, forests and Coalcorp be discontinued. ${ }^{117}$ On December 221988 Deputy Prime Minister Palmer and Rodger met with Mahuta and other TMTB representatives. Mahuta handed a letter to the Ministers that detailed the need to ensure that no further Crown lands,

\footnotetext{
${ }^{113}$ Ward, An Unsettled History, 35-36; Geoffrey Palmer to Graham Latimer, 20 July 1987; Latimer to Palmer, 28 July 1987; Palmer to Latimer, 21 September 1987; Latimer to Palmer, 5 October 1987: all NT140 F(iii)7, Box 133, MB archives.

${ }^{114}$ Treaty of Waitangi (State Enterprises) Act 1988, section 27B.

${ }^{115}$ Carmen Kirkwood to Palmer, 26 February 1988, TC30 Vol. 2, OTS archive; McCan, Whatiwhatihoe: The Waikato Raupatu Claim, 251-252.

${ }^{116}$ Mahuta to Richard Prebble, 10 March 1988; Prebble to Mahuta, 31 March 1988: all TC30 Vol. 2, OTS archive \& R Vol.1, Box 3, W-T archives; McCan, Whatiwhatihoe: The Waikato Raupatu Claim, 258.

${ }^{117}$ Denese Henare to Palmer, 21 November 1988; Hare Puke and Mahuta to Palmer, 22 December 1988: all TC30 Vol. 2, OTS archive \& RC1 Vol.1-2, Box 24, W-T archives; McCan, Whatiwhatihoe: The Waikato Raupatu Claim, 257-258.
} 
including Coalcorp assets, were sold in the Waikato rohe (region) along with recommendations for possible approaches to compensation to settle Waikato-Tainui claims to confiscated lands. $^{118}$

Rodger apologised in a letter to Denese Henare in early January 1989 for the long delay. There was a Cabinet shuffle in the second half of 1988 as various Ministers resigned and were replaced. Rodger agreed that the negotiations would begin in 1989 but declined Waikato's request to halt the sale of Coalcorp asests. Rodger said he appreciated that land would be important in a redress package and emphasised that there still remained abundant sources of Crown land in the Waikato rohe to satisfy their claims. The sale of Coalcorp would proceed, he said, because only the licences to extract coal would be sold. The land would remain safeguarded under the protection mechanism developed in the Treaty of Waitangi (State Enterprises) Act 1988. Rodger noted that while the option of having their claims heard by the Waitangi Tribunal remained open should negotiations fail to be successful, there should be no court action during the negotiations in a spirit of "good faith." 119 The TMTB, however, did not agree that only the land was subject to WaikatoTainui claims: they also had rights to the coal. After repeated threats of court action throughout 1987 and 1988, Rodger's letter only served to push the TMTB to finally lose patience with the Crown. It soon filed proceedings in the High Court to halt the sale of Coalcorp. For Waikato-Tainui negotiators, the ownership of land and coal were inextricably connected, as David McCan has shown in Whatiwhatihoe. Waikato-Tainui approached the issue with the re-assertion of their rangatiratanga as a focus, and a holistic approach to the

\footnotetext{
${ }^{118}$ Hare Puke, Henare \& Mahuta to Palmer, 22 December 1988; Henare to Stan Rodger, 22 December 1988: all TC30 Vol. 2, OTS archive \& RC1 Vol.1-2, Box 24, W-T archives; McCan, Whatiwhatihoe: The Waikato Raupatu Claim, 258.

${ }^{119}$ Rodger to Henare, 1 January 1989, TC30 Vol.2, OTS archive; McCan, Whatiwhatihoe: The Waikato Raupatu Claim, 259.
} 
ownership and management of land. Both the land and whatever was underneath the land were connected and thus their claims to land also included claims to coal. ${ }^{120}$

Although the proposed sale of Coalcorp loomed large over the build-up to the negotiations in 1989, the Crown continued to build momentum to begin negotiations with Waikato. Waikato put its position in writing to the Crown in December 1988, but their energies were largely centred on preventing the sale of Coalcorp. Mahuta continued to maintain that their claims were to the coal as well as the land, and requested that the sale of Coalcorp be postponed until negotiations were completed, much less begun. The Crown, for its part, stuck to the principle that only the land, not natural resources such as coal, was subject to the protection mechanism provisions of the Treaty of Waitangi (State Enterprises) Act 1988. Since negotiations had not yet begun, the Crown was not yet willing to concede which of Waikato-Tainui's claims were valid as that would occur during the direct negotiations. As a result, there was little consideration by the Crown of a moratorium on the sale of state assets in general in the Waikato-Tainui region, much less specific Coalcorp assets. $^{121}$

The Crown's policy had been to refuse to negotiate if claimants took action in Court. However, a Treasury official made an innovative proposal that the Crown relax its strict policy on refusing to negotiate while litigation proceeded. The official argued that providing some leniency would allow the two sides to negotiate on matters that were unrelated to the issue of coal. This would demonstrate that there had been some effort made by the Crown

\footnotetext{
${ }^{120}$ McCan, Whatiwhatihoe: The Waikato Raupatu Claim, 251-296.

121 "Waikato Negotiations: Report to Cabinet," 11 January 1989, OTS archive TC30 Vol. 3; McCan, Whatiwhatihoe: The Waikato Raupatu Claim, 258-259.
} 
when the matter was considered by the Court. ${ }^{122}$ The Crown Law Office (CLO) agreed and eventually so did Cabinet.

\section{Scoping negotiations: July and August 1989}

In late 1988, ToWPU was established. Alex Frame - former Senior Law Lecturer at Victoria University of Wellington - was appointed as its Director. In mid-1989 Frame travelled to Waikato with a small team of ToWPU officials for early discussions with Waikato-Tainui representatives. ${ }^{123}$ Waikato-Tainui's initial negotiations with the Crown began with these informal scoping sessions that were held from May to August 1989 at Tapuwae o Hounuku, a farm near Kawhia managed by the TMTB. ${ }^{124}$ The all-male negotiating team of Frame and three other men each respectively from ToWPU, CLO and Treasury, was countered by an all-female negotiating team for Waikato-Tainui: Raiha Mahuta, Julie Wade, Iti Rawiri, Mere Taka and Dr. Pare Hopa. The gender composition of the teams was not the most significant aspect of the negotiations, but it was particularly noted in the private correspondence of the TMTB. ${ }^{125}$ It is unclear exactly how the Waikato-Tainui negotiating team was chosen, but each was either a member of the TMTB or had strong affiliations with the Kīngitanga.

This first set of negotiations was integral for laying down the future framework that would govern the negotiations. Waikato-Tainui negotiators used it as an opportunity to

\footnotetext{
122 Treasury official 1 to Alex Frame, 04 April 1989, TC30 Vol.2, OTS archive.

${ }^{123}$ Minutes of a meeting held between the Crown and Waikato negotiators, 21 June 1989, TC30 Vol.5, OTS archive \& RC1 Vol.1-2, Box 24, W-T archives, 10, 11; Minutes of a meeting held between the Crown and Waikato negotiators, 4 July 1989; Minutes of a meeting held between the Crown and Waikato negotiators, 5 July 1989, TC30 Vol.6, OTS archive \& RC1 Vol.1-2, Box 24, W-T archives; Treasury official 1, "Waikato Negotiations: $2^{\text {nd }}$ Week of Scoping Phase”, 7 July 1989, TC30 Vol.6, OTS archive.

${ }^{124}$ McCan, Whatiwhatihoe: The Waikato Raupatu Claim, 264.

125 Treasury official 1 to Treasury official 2, 23 June 1989, TC30 Vol.5, OTS archive; Raiha Mahuta to Robert Mahuta \& TMTB, “Scoping Discussions,” 17 May 1989, RC1 Vol.1, Box 24, W-T archives. This was certainly a curious aspect of these scoping negotiations - why had the Crown team been only men and the WaikatoTainui team only women?
} 
discuss long held grievances. There were a series of fundamental disagreements. The Crown remained firm on the view that the findings of the 1920s Sim Commission into WaikatoTainui grievances still applied: the confiscation of Waikato land in the 1860s was excessive, but that confiscation was both necessary and lawful under the relevant legislation. ${ }^{126}$ At least two of the Crown officials and possibly all four believed that the confiscation legislation was nonetheless unjust.

The first topic of the meeting was the backlash that Waikato-Tainui had received from the general public when it began to pursue its claims. Waikato-Tainui sought to engage in a campaign with the government to educate the public on the historical grievances of WaikatoTainui. However, it soon became apparent that the Crown and Waikato-Tainui themselves were in disagreement on many issues, except for some broad outlines of the war and confiscation. Waikato-Tainui believed that the invasion of the Waikato and the subsequent confiscation were illegal. Waikato-Tainui attempted to point to the 1981 Bentinck-Stokes' report (produced by JG Bentinck-Stokes for the Secretary of Māori Affairs) that raupatu was “unlawful,” and the Tribunal’s findings in the 1985 Manukau Harbour Report that indirectly condemned the invasion of the Waikato. ${ }^{127}$ Waikato-Tainui’s reliance on the Bentinck-Stokes report was contested by the Crown, but the findings of the Manukau Harbour Report were accepted. Frame referred to Michael Litchfield's 1985 article in the VUW Law Review which

\footnotetext{
${ }^{126}$ In the 1920s, the government established the Sim Commission to investigate some of the major Māori grievances against the government, one of which was the confiscation of land in the Waikato. The Sim Commission concluded that the confiscations were unjust but that Waikato-Tainui had been deserving of some kind of punishment because they had rebelled against the Crown: Mark Hickford, "Strands from the Afterlife of Confiscation, Property Rights, Constitutional Histories and the Political Incorporation of Māori, 1920s," R Boast and R Hill (eds.) Raupatu: The Confiscation of Māori Land (Wellington: VUW Press, 2009), 183-203. ${ }^{127}$ Although the Bentinck-Stokes report was written regarding the Taranaki confiscations, his conclusions about the lawfulness of the 1863 Settlements Act applied to all the areas of land confiscated under that legislation: JG Bentinck-Stokes, "Report on Legal and Historical Aspects of the Taranaki Confiscations," 20 May 1981, Wai 143, A26; Waitangi Tribunal, Report of the Waitangi Tribunal on the Manukau Claim (Wai-8), (Wellington: Government Printer, 1985), 31-33.
} 
found that although the confiscations were unjust they were not illegal. ${ }^{128}$ In contrast, the Bentinck-Stokes Report was seen to be based on rather flimsy use of all the legal and historical evidence available at the time.

Waikato-Tainui felt that they had a good relationship with the Crown, but that the key point in achieving a durable settlement was in convincing the public. Nevertheless, there were substantive issues for the negotiations to address. Waikato-Tainui sought the remaining land in the Crown's hands in the Waikato-Tainui rohe as redress for the military invasion of the Waikato and the confiscation that followed, compensation for the Crown's exploitation of the coal resource during the length of the twentieth century, and lost development opportunities. This was sizeable redress. The Treasury official, in his report to his superiors, commented that the Waikato-Tainui negotiators understood that redress in full would not be fiscally possible. Waikato-Tainui wanted to remain realistic but it nonetheless pressed the Crown not to trivialise their historical grievances by thinking they could be paid off with a small sum of money. ToWPU officials and the Crown Law representative believed that the most likely result of the negotiations was an interim settlement. ${ }^{129}$

Although there was a need for a level of agreement with regard to the historical "facts" the Crown tried to stay away from getting bogged down into the details: rather, Frame stated that both sides could agree that there was significant damage which resulted from the confiscations and the negotiations should be focused on addressing that grievance. WaikatoTainui on the other hand made it clear that the details were very important and that WaikatoTainui's input into the formulation of historical rationales for the settlement was necessary. Frame and the Treasury official warned Waikato-Tainui that, in their assessment, Cabinet

\footnotetext{
${ }^{128}$ Alex Frame, "Waikato Negotiations: First Confidential Report,” 30 May 1989, OTS archive, TC 30 Vol. 4; Michael Litchfield, "The Confiscation of Māori Land,” VUW Law Review Vol. 15 No. 4 1985, 337-362.

${ }^{129}$ Treasury official 1 to Treasury official 2, 23 June 1989, TC30 Vol.5, OTS archive.
} 
would not accept that the invasions were illegal, just that they were excessive and unjust. Waikato-Tainui negotiators continued to return to the alleged illegality of the confiscation. Crown officials tried to stress that together the two parties needed to determine how best to convince Cabinet to provide ample compensation and that would not occur by insisting on the illegality argument. ${ }^{130}$ The June 1989 meeting ended with Waikato-Tainui in effect lecturing the Crown on the wrongs committed and the long-standing effects they had on their communities. While the Crown was willing to listen there was clearly some discomfort as the meeting ended. This could have been because of the awkward situation in which sympathetic Crown officials found themselves: empathising with Waikato-Tainui but nonetheless serving in an official capacity as a representative of the entity that had committed the "sins" in the first place. ${ }^{131}$ At a Canadian academic conference, Mohawk political theorist Taiaiake Alfred commented that in the case of Canada "there needs to be struggle in order to lay out a path to co-existence, and that the process of being uncomfortable is essential for non-indigenous people to move from being enemy to adversary to ally." 132 The Canadian situation described by Alfred applied well to the situation in which Crown officials found themselves during these scoping negotiations. The discomfort experienced by Crown negotiators was necessary to enable the Crown to understand the depth of historical pain felt by Waikato-Tainui.

Little happened for the rest of 1989 as Waikato-Tainui focused its energy on the pending alienation of Coalcorp land and assets. After filing their case early in 1989, the TMTB's Coalcorp case was heard by the Court of Appeal in August $1989 .{ }^{133}$ The Court of Appeal found in favour of the TMTB and issued an injunction against the sale of Coalcorp.

\footnotetext{
${ }^{130}$ Minutes of a meeting held between the Crown and Waikato negotiators, 4 July 1989; Minutes of a meeting held between the Crown and Waikato negotiators, 5 July 1989, TC30 Vol.6, OTS archive \& RC1 Vol.1-2, Box 24, W-T archives; McCan, Whatiwhatihoe: The Waikato Raupatu Claim, 264.

${ }^{131}$ Minutes of a meeting held between the Crown and Waikato negotiators, 20 June 1989, OTS archive, TC 30 Vol. 4.

${ }^{132}$ Paulette Regan, “A Transformative Framework for Decolonizing Canada: A Non-Indigenous Approach,” Presented at the IGOV Doctoral Student Symposium, 20 January 2005, 3.

${ }^{133}$ McCan, Whatiwhatihoe: The Waikato Raupatu Claim, 273-275.
} 
The President of the Court of Appeal, Sir Robin Cooke, advocated a negotiated settlement and thought that the TMTB should receive a substantial portion of the coal resources in its region, albeit less than half. ${ }^{134}$ In early March 1990 the Crown and Waikato-Tainui negotiating teams finally met again. ${ }^{135}$ One of Waikato’s demands had been that someone with more political leverage represent the Crown such as a Cabinet Minister or the AttorneyGeneral, so Justice Minister Bill Jeffries led the negotiations with the aid of Alex Frame and two other ToWPU officials. ${ }^{136}$ Unfortunately the Treasury official who had been involved in the scoping negotiations had died. Waikato-Tainui's only holdover from the scoping negotiations was Dr. Pare Hopa and she was joined by Robert Mahuta, Denese Henare, Hare Puke and Hinga Maggie. ${ }^{137}$ Much like the first scoping negotiations, all of these representatives were either members of the TMTB or strongly affiliated with the Kinngitanga. Henare was the TMTB's primary legal advisor while the rest were active TMTB members. Henare was involved in the Waikato confiscation claim from throughout the 1980s until the settlement was completed in $1995 .^{138}$

Finality and the Waikato Maniapoto Claims Settlement Act 1946: 1990

Debates surrounding the extent to which previous arrangements with the Crown fully settled historical claims, including the Waikato-Maniapoto Māori Claims Settlement Act

\footnotetext{
${ }^{134}$ Tainui Maaori Trust Board v Attorney-General [1989] 2 NZLR 513. McCan, Whatiwhatihoe: The Waikato Raupatu Claim, 279-282. While the Crown has used a diverse range of assets as redress, it still refuses to use natural resources other than pounamu.

${ }^{135}$ McCan, Whatiwhatihoe: The Waikato Raupatu Claim, 297-301.

${ }^{136}$ Mahuta to Henare, 9 January 1990, RC1Vol 1, Box 3, W-T archive.

${ }^{137}$ Mahuta to Alex Frame, 3 March 1990, TC30 Vol. 7, OTS archive.

${ }^{138}$ She was the niece of prominent Nga Puhi rangātira Sir James Henare. When Denese Henare first considered working for the Tainui Māori Trust Board she sought her uncle's advice. Sir James Henare told her that she should work for the Trust Board because it was their Treaty that had burdened Waikato, alluding to the origin of the Treaty of Waitangi in areas controlled by Nga Puhi and others at the top of the North Island. Interview with Denese Henare, 26 May 2011.
} 
1946, dominated the negotiations in the first half of $1990 .{ }^{139}$ Mahuta claimed that the 1946 settlement was only a partial settlement because the return of land was not included. After losing the Coalcorp case the Crown kept to the position that the 1946 Act had been seen at the time as full and final. For the Crown, the 1946 settlement was to be the starting point of the current negotiations. Mahuta had gone to great lengths to convince those within WaikatoTainui that the 1946 settlement was inadequate, especially those that had been directly involved. Mahuta argued that the 1946 settlement was forced upon the iwi. Justice Minister Bill Jeffries and ToWPU officials disagreed. Jeffries and his officials argued that the 1946 settlement was the best that could be negotiated in the context of the times. As a result the iwi had accepted the offer, and the settlement had not been forced upon Waikato-Tainui. Te Puea had commented at the time that the return of land was still necessary, but that the settlement at the time was appreciated. ${ }^{140}$

In reports to Cabinet in late 1989, Frame wrote that the question of re-opening the full and final settlements of the 1940s was not completely necessary. In the months to come, Frame maintained that while those agreements were full and final by law, he readily admitted that they had not achieved what they had set out to do. This was the point of the negotiation process: to fulfil the spirit of those agreements rather than re-negotiating the entire WaikatoTainui claim. ${ }^{141}$ Based on his interactions with Ministers, Frame believed that the 'spirit' argument would be the only way to persuade Cabinet to offer additional compensation and the return of land. The value of the $£ 10,000$ annual grant provided in the 1946 settlement that established the TMTB had eroded severely by the mid-1960s. The TMTB and other Māori

\footnotetext{
${ }^{139}$ The 1946 Waikato-Maniapoto Claims Settlement Act provided a limited amount of compensation to address the confiscation of Waikato lands in the 1860s, but did not include the return of land.

${ }^{140}$ Two separate minutes of a meeting held between the Crown and Waikato negotiators, 5 March 1990, TC30 Vol.7, OTS archive, one by James Ritchie and the second, “The Crown”. The Crown version of the minutes is much shorter and thus there is little detail. On the Crown copy it says "these were altered by the Minister [Jeffries]." Michael King, Te Puea: A Life, 222-225; Paul Diamond, A Fire in Your Belly: Māori Leaders Speak, 124-125; McCan, Whatiwhatihoe: The Waikato Raupatu Claim, 215, 304-305.

${ }^{141}$ Alex Frame, “The 1940s Settlement of Major Māori Claims”, 6 November 1989, TC30 Vol.7, OTS archive.
} 
Trust Boards, such as the Ngāi Tahu Māori Trust Board, had lobbied the Crown since the mid-1960s to index the annual grant to the rate of inflation and provide compensation for the decades of under payment. The Crown responded by providing the grants in perpetuity. During their negotiations with Waikato-Tainui, the Crown contracted a statistician to write a report on the effect of inflation on the annual grants provided to Māori Trust Boards such as the TMTB. The value of the TMTB’s loss was approximately $\$ 8$ million. ${ }^{142}$

Frame presented to Cabinet some of the different reasons why the Crown could argue in favour of, and against more negotiations. On one end of the spectrum was the Crown's response to a suggestion in 1979 that the Taranaki claim be re-opened-the 1940s era settlements were full and final; on the other was Mahuta's demand for all of the Crown's land that remained in the Waikato, plus compensation for the rest of the land that had been confiscated but could not be returned because it was now in private ownership. Frame put forth Waikato owning the bed of the Waikato River as a possible substitute for what he termed the "orphan factor." Repeatedly throughout the scoping phase, Waikato-Tainui negotiators had put forward the idea that Waikato-Tainui felt like orphans as a result of the confiscation of land. Frame stated that "the 1946 settlement has not fully achieved its purpose because it fails to address the feeling of alienation from the land.” Sir Robin Cooke stated in the 1987 New Zealand Māori Council v. Attorney-General case that the payment was trivial and the Tribunal would probably condemn the confiscations. Prime Minister Peter Fraser had even remarked in Parliament in 1946 that Waikato had not considered the settlement full or

\footnotetext{
${ }^{142}$ Frame to Jeffries, 10 May 1990, TC30 Vol.8, OTS archive; John Robinson, 'Indexation of Payments to Māori Trust Boards,' 11 January 1990, TC30 Vol.7, OTS archive; McCan, Whatiwhatihoe: The Waikato Raupatu Claim, 215, 303-304.
} 
final. ${ }^{143}$ Nonetheless Frame knew that Treasury, Cabinet and the CLO would insist that the 1946 agreement was a full and final settlement.

In March 1990 Justice Minister Bill Jeffries and Mahuta engaged in a series of correspondence which focused on factually rebutting the other on the history of the 1946 settlement and whether it was full and final. Jeffries maintained that it had to be a starting point for the negotiations and that the return of land could be a part of fulfilling the spirit and intent of the 1946 settlement. The Crown's proposal for settlement was to use the approximately \$8 million of payments lost to inflation specifically to purchase land, either surplus to the Crown or privately, to meet Waikato-Tainui's demand for land. ${ }^{144}$ WaikatoTainui was concerned that what was "already being contemplated in general Maaori policy should be offered to Waikato in the guise of a negotiated settlement of its tribal claim." Waikato-Tainui were not seeking to update their annual grants to inflation, as all other Māori Trust Boards were set to receive, but a fresh set of negotiations that would fully address their claims.

The limited sum that the Crown was offering would prevent any further developments in the negotiations at this time. Treasury's role was prominent in these early negotiations. Treasury found little chance of an "enduring settlement” because Waikato negotiators were not willing to admit any finality to any negotiated agreement. "They want a continuing reminder for both the Crown and their people of the wrong done to them. An enduring settlement is unlikely at this stage or for a long time to come.”146 Treasury though made no

\footnotetext{
${ }^{143}$ Frame, “Tainui Negotiations”, 5 February 1990, TC30 Vol.7, OTS archive.

${ }^{144}$ Mahuta to Jeffries, 15 March 1990; Jeffries to Mahuta, 21 March 1990; 29 March 1990, TC30 Vol.7, OTS archive \& RC1, Vol.3, Box 7, W-T archives.

${ }^{145}$ Mahuta to Jeffries, 13 March 1990, TC30 Vol.7, OTS archive \& RC1, Vol.3, Box 7, W-T archives, 2; McCan, Whatiwhatihoe: The Waikato Raupatu Claim, 304-305.

${ }^{146}$ Treasury official 3 to ToWPU official 1 and Frame, 10 May 1990, TC30 Vol.8, OTS archive.
} 
mention of possibly addressing the continuing reminder with a substantial lump sum that would provide the amount of land that Waikato-Tainui were seeking in their settlement.

Then, in August 1990, Waikato-Tainui representatives provided a submission to the United Nations (UN) Sub-Commission on the Prevention of Discrimination and Protection of Minorities in Geneva and attested to the continuing colonial legacy of the confiscations and the refusal of the current government to engage in substantive negotiations. ${ }^{147}$ One of the conditions of the negotiations was that public statements would not be released without notifying the other party and the international stage upon which Waikato-Tainui chose to voice its displeasure with the Crown caused a significant backlash both from the public and the Crown. ${ }^{148}$ As David McCan has commented, Waikato-Tainui negotiators perceived that despite the direction from the Court of Appeal to engage in direct negotiations there was a lack of commitment from the Crown. Mahuta felt that direct negotiations with the Crown had not advanced the Waikato-Tainui claim, and as a result human rights organisations such as the UN were the next option. ${ }^{149}$

The day before Waikato's presentation to the UN, Jeffries requested permission from Cabinet to present an offer to the iwi in exchange for the lifting of the injunction on the sale of Coalcorp. The offer was much larger than the original \$8 million in arrears payments offered first-approximately \$17-20 million—but it was still far below Waikato-Tainui’s expectations. The Crown proposed a settlement that consisted of $\$ 10$ million in surplus Coalcorp properties, 60 house lots, 12 farm lots, a hostel and some other properties, without

\footnotetext{
147 “Submission to Working Group on Indigenous Peoples," 1 August 1990, TC30 Vol.9, OTS archive; McCan, Whatiwhatihoe: The Waikato Raupatu Claim, 307-310.

${ }^{148}$ Frame to Jeffries, 7 August 1990, TC 30 Vol. 9, OTS archive; Ross Baker to Geoffrey Palmer, 14 July 1990, TC 30, Vol.9, OTS archive. Robert Joseph has commented on the use of the politics of shame by indigenous groups around the world but especially in New Zealand and Canada: 'The Government of Themselves: Indigenous Peoples’ Internal Self-Determination, Effective Self-Governance and Authentic Representation: Waikato-Tainui, Ngāi Tahu and Nisga'a.' Ph.D Thesis (Law), University of Waikato, 2006, 157-159.

${ }^{149}$ McCan, Whatiwhatihoe: The Waikato Raupatu Claim, 307-308.
} 
ownership of the coal, on top of the $\$ 8$ million that the Crown proposed to transfer to Waikato in arrears for payments to the Trust Board. ${ }^{150}$ After Waikato-Tainui made their public protest at the UN the offer was still sent out as it had been approved by that Cabinet meeting the day before the UN presentation. The best that Mahuta could say was if that offer was construed as an interim settlement, it would be acceptable, but in no way could the Crown's offer be traded for lifting the injunction on the sale of Coalcorp. Mahuta recommended at TMTB meetings and at a hui-ā-iwi at Turangawaewae that the iwi should reject the settlement. The Crown's offer was therefore refused because of the limited nature of the settlement offered by Cabinet. As a result the amount of land available for purchase was too insignificant for Waikato-Tainui to trade the leverage that had been gained from the Coalcorp victory. From the point of view of Waikato-Tainui, the proposed settlement would do little to enhance Waikato-Tainui rangatiratanga. ${ }^{151}$

As Labour entered the 1990 election scheduled for 27 October, Mahuta claimed in a speech to the NZ Planning Council in late September 1990 that although there was a slim chance that Labour would still be in power by the end of the year, he and Waikato-Tainui would still be there to negotiate. He stated further that: "[t]he Government should either treat Waikato as if they did sign the Treaty of Waitangi; or else treat them as if they were a sovereign nation. The other option - seemingly the one the Government is pursuing - is to treat Waikato as nobodies." ${ }^{152}$ When Mahuta returned to the Waikato to face the people and tell them they had come back empty handed from the negotiation process with the Crown a

\footnotetext{
150 TOW (90) 23, 31 July 1990, TC30 Vol.9, OTS archive; Jeffries to Mahuta, 6 August 1990, TC30 Vol.9, OTS archive; Jeffries to Mahuta, 15 October 1990, TC30 Vol.10, OTS archive. Last two also RC1, Vol.4, Box 7, WT archives; McCan, Whatiwhatihoe: The Waikato Raupatu Claim, 310-311.

${ }^{151}$ Mahuta to Jeffries, 19 October 1990, TC30 Vol.10, OTS archive \& RC1, Vol.4, Box 7, W-T archives; McCan, Whatiwhatihoe: The Waikato Raupatu Claim, 312.

152 The paramount leader of Tainui at the time of the Treaty was Te Wherowhero and although he had signed the 1835 Declaration of Independence, he had not signed the Treaty of Waitangi in 1840.
} 
kaumatua remarked to him, "It is better to have nothing than to be nothing." 153 Led by Mike Moore, Labour lost the 1990 election in a landslide to Jim Bolger and the National Party. ${ }^{154}$ It was now up to the Crown officials who had begun the process under Labour to continue their work under National.

153 Mahuta, “Speech to the NZ Planning Council,” 27 September 1990, TC30 Vol.9, OTS archive; Sir Douglas Graham. “The Treaty and Treaty Negotiations,” in Margaret Clark’s The Bolger Years: 1990-1997 (Wellington: Dunmore Publishing, 2008), 172; Richard Hill, Māori and the State: Crown-Māori Relations in New Zealand/Aotearoa, 1950-2000, 253.

${ }^{154}$ Jack Vowles and Peter Aimes, Voters'Vengeance: The 1990 Election in New Zealand and the fate of the Fourth Labour Government (Auckland: Auckland University Press, 1993). 


\section{Fourth National Government: Negotiations with Waikato-Tainui}

After the Labour government was defeated it was initially unclear how the new National government planned to address Treaty claims. Despite claims to the contrary in his autobiography, Jim Bolger had been critical of the legislative and judicial advances made in the 1980s and it was not apparent that he would continue the work that had just begun under Labour. ${ }^{155}$ His first Minister of Māori Affairs, Winston Peters, was not very encouraging for those who appreciated the increasing place of the Treaty of Waitangi within New Zealand's legislative and legal systems. Peters had gained a great measure of popularity by appealing to the entrenched supporters of a monocultural New Zealand. Peters was originally placed in charge of all Treaty negotiations, including those that had begun with Waikato-Tainui and were set to begin with Ngāi Tahu. Due to a combination of lack of interest and political scandals he never actively became involved.

The Minister of Justice, Doug Graham, was responsible for the Treaty of Waitangi Policy Unit as it was a Unit within the Department of Justice. For the end of 1990 and most of 1991 he was not officially in charge of Treaty matters, but this situation changed when Peters was sacked in October 1991. ${ }^{156}$ After Peters was sacked, Graham was appointed as Minister in Charge of Treaty Negotiations. Graham was more encouraging than Peters, but Graham had voted against providing the Tribunal with powers to inquire into historical claims in 1985 so it was not guaranteed that he would be willing to continue the work begun

\footnotetext{
${ }^{155}$ McCan, Whatiwhatihoe, 284; Ward, An Unsettled History, 34; Jim Bolger, A View from the Top (Auckland: Viking Press, 1998), 175.

${ }^{156}$ Tom Brooking, The History of New Zealand (Westport, Connecticut: Greenwood Press, 2004), xxxii; Richard Hill, Māori and the State: Crown-Māori Relations in New Zealand/Aotearoa, 1950-2000, page 251253.
} 
under Labour. Graham later would comment that he only voted against the legislation because he had to follow his Party as a backbencher. ${ }^{157}$

Early in 1991 Mahuta requested a meeting with Prime Minister Jim Bolger and his Ministers and asked when negotiations might be able to resume. Mahuta thought that the negotiations with the Labour government had not advanced as a result of a lack of agreement on the principles and process guiding the negotiations. In his last letter to outgoing Labour Justice Minister Bill Jeffries, Mahuta had pointed out that Waikato and the Crown agreed on four out of six negotiating principles and thus there was definitely some agreement. The suggested agenda for the negotiations which ToWPU and Waikato officials had negotiated in 1989 had been rejected by Cabinet, and thus it was not so much officials that were to blame for that lack of agreement but Cabinet itself. ${ }^{158}$

Before negotiations formally began, a ToWPU official provided a memorandum for Graham which addressed some of the key issues that led to the breakdown of the WaikatoTainui negotiations. His advice reflected the comments made by Mahuta to Bolger. "At times the Crown has mistakenly used the offer to address Waikato's grievance as a quid pro quo for lifting of the injunction [on Coalcorp]. This, like focusing on cash compensation, indexation of Waikato's annuity, and tagging any settlement to the 1946 Waikato-Maniapoto Māori Claims Settlement Act has impeded progress in the negotiations.” The official further alluded to the question of "Tainui's understanding of the settlement, particularly its 'fullness and finality’” and that the Waitangi Tribunal did not consider any of the 1940s settlement to be beyond scrutiny or revision. The fact that the Crown had stuck to its position of only modernising the 1946 settlement severely limited the Crown's options and "insulated the

\footnotetext{
${ }^{157}$ Interview with Graham, 22 May 2011; Graham was reported to have had lunch nearly every week through the 1980s and 1990s with a prominent lawyer who specialised in Treaty matters, Paul Temm; Ward, An Unsettled History, 34.

${ }^{158}$ Mahuta to Jim Bolger, 4 January 1991, TC30 Vol. 10, OTS archive.
} 
Crown from any acknowledgment of the injustice done to Waikato." ${ }^{159}$ Peters, before he was sacked, had asked for a review of the 1989 Principles with the expectation that the Principles would be watered down. ToWPU officials recommended that the National government adopt the same Principles for Crown Action on the Treaty of Waitangi that Labour had produced in 1989 and build on those original proposals. ${ }^{160}$

The Crown's negotiating team for the Waikato-Tainui negotiations was led by Graham after Peters' dismissal. Waikato-Tainui proposed an A and B team structure, and Graham agreed. The A team comprised Graham as the principal with Secretary of Justice David Oughton, the CEO of what was then Manatu Māori but was soon to be renamed Te Puni Kōkiri (TPK) ${ }^{161}$, Wira Gardiner, and a Treasury official. The B Team consisted of an official from ToWPU, a lower ranking official from Treasury and a Crown Law official. A contractor, Paul Hendry, was brought in later in the process to help with the SOE and other Crown enterprises - he met with all the relevant CEOs and walked them through the implications of the Crown's proposals for their balance sheets. ${ }^{162}$

Waikato-Tainui's negotiating team was led by Mahuta. Their A Team consisted of long-time TMTB legal advisor Denese Henare and commercial advisor Brent Wheeler. Wheeler was an economist from Wheeler Campbell Securities Ltd who had previously worked as an economic analyst for the New Zealand Treasury and the Office of the Minister

\footnotetext{
${ }^{159}$ TOWPU official 2, early 1991, AAKWW5105781226, Archives NZ, 1-2.

${ }^{160}$ ToWPU official 3 to Doug Graham, 26 March 1991, RC V5, B8, Waikato-Tainui archives.

${ }^{161}$ In 1989 the Department of Māori Affairs was replaced with two organisations: Manatu Māori (the Ministry of Māori Affairs) and Te Tira Ahu Iwi (the Iwi Transition Agency). Following the National Party's victory in the 1990 election, further restructuring was proposed and Manatu Māori and Te Tira Ahu Iwi were combined to form Te Puni Kokiri, the Ministry of Māori Development: Richard Hill, Māori and the State: Crown-Māori Relations in New Zealand/Aotearoa, 1950-2000, 241-243, 248-252.

${ }^{162}$ In mid-1992 Hendry joined forces with Brent Wheeler, Waikato's primary commercial advisor, and proffered his resignation to the Crown for the obvious conflict of interest which it would create in relation to Waikato's negotiations with the Crown.
} 
for State Owned Enterprises. ${ }^{163}$ Waikato-Tainui’s B Team was initially Shane Solomon and Mike Ashby, but Ashby was later replaced by John Te Maru. At this point Dr. Ngapare Hopa was also an informal member of the Waikato-Tainui negotiating team. Denese Henare had perhaps the most critical views regarding the Crown of the entire Waikato-Tainui negotiating team. Late in the negotiation she was especially concerned with the hasty nature of the final process and the potential for legal challenges. ${ }^{164}$ In addition to the formal meetings involving scores of officials and advisors from each side who complemented the official team memberships and the monthly officials-level meetings established at the beginning of the process, late in the negotiations Mahuta and Graham would also occasionally meet without any advisors present to try to hammer out sticking points in the negotiations.

After the first two formal meetings in late 1991 and early 1992, Waikato-Tainui advisors recommended to Crown negotiators that the structure of the negotiations would be better served by having Mahuta and Graham act only as principals who would ratify decisions made by their officials and advisors that dealt with the minutiae of the negotiations. They thought it would be best to create working groups to limit the time Mahuta and Graham

\footnotetext{
${ }^{163}$ Brent Wheeler Full CV, http://www.brentwheeler.com/wp-content/uploads/2014/01/Brent-Wheeler-FullCV.pdf, accessed 28 March 2013.

164 "Meeting between Crown and Waikato negotiators,” 13 December 1994, TC30 Vol. 41, OTS archive; "Meeting between Crown and Waikato negotiators," 29 November 1994, RC1, Correspondence Vol 37, December 1994, Box 15., W-T archives, 5; "Meeting between Crown and Waikato negotiators,” 13 December 1994, TC30 Vol. 41, OTS archive; "Meeting between Crown and Waikato negotiators,” 29 November 1994, RC1, Correspondence Vol 37, December 1994, Box 15., W-T archives, 3; Henare to Mahuta \& John Te Maru to Mahuta, 14 December 1994, RC1, Correspondence Vol 37, December 1994, Box 15, W-T archives; Interview with Brent Wheeler, 24 May 2011; ToWPU official 4 to Graham, 15 December 1994, AAKW W5105 781222, Archives NZ; Treasury official 4 to Treasury official 5, 15 December 1994, TC30 Vol. 42, OTS archive; Henare to ToWPU official 4, 19 Deccember 1994, TC30 Vol. 42, OTS archive, 1; Henare to Mahuta, 19 December 1994; Peter Rowe to Mahuta, 19 December 1994: both RC1, Correspondence Vol 37, December 1994, Box 15, W-T archives; Diamond, 134; Mahuta to Henare, 19 December 1994, RC1, Correspondence Vol 37, December 1994, Box 15, W-T archives; Shane Solomon, “Meeting with Denese,” 17 November 1994, RC December August 1994, Box 32, W-T archives.
} 
(the principals) had to spend on individual issues. The Crown agreed and the new negotiating format began in earnest in March 1992. ${ }^{165}$

Without any detailed Treaty policy the government was often accused by WaikatoTainui of purposefully delaying the negotiations. The Crown for its part believed that it was responding to arguments from Waikato-Tainui without any preconceived notions. Although the Crown was generally opposed to interim settlements, it was forced to placate WaikatoTainui with various mechanisms such as offering the return of land from late 1991 onwards as a gift and gesture of good will. Before the two parties formally met, the Crown informed Waikato-Tainui that the decommissioned Hopuhopu Army Base was available for transfer to the iwi to meet Waikato-Tainui's principle that as land was taken so land must be returned ("i riro whenua atu me hoki whenua mai”). ${ }^{166}$ At first, Waikato-Tainui were stunned that the Crown was actually returning land and did not believe Graham when he made the announcement at Whaataapaka marae in late $1991 .{ }^{167}$ Although the return of the base initially engendered some substantial good will between the two parties, eventually the significant financial liabilities that the base carried eroded some of that good will. ${ }^{168}$

\footnotetext{
${ }^{165}$ Meeting between Waikato and Crown B Teams, 26 March 1992, TC30 Vol. 19, OTS archive. Later in the negotiations the frequent informal contact between Mahuta and Graham became a concern for both WaikatoTainui and Crown advisors who were worried that negotiations were being conducted without their input. At times ToWPU was concerned that certain changes to previous agreements that had been agreed to at the principal's level were being changed by advisors: ToWPU official 4 memorandum, 22 November 1994, TC30 Vol. 40, OTS archive. Solomon \& Mahuta memos, 22 November 1994;Henare to Mahuta, 22 November 1994; RC December - August 1994, Box 32, W-T archives; ToWPU official 4 to Henare \& Henare to ToWPU official 4, 11 December 1994, TC30 Vol. 41, OTS archive.

${ }^{166}$ Mahuta to Jim Bolger, 24 June 1991, AAKW W5105 7812 26, Archives NZ; Bolger to Mahuta, 19 July 1991, RC Vol 5, Box 8, W-T archives; Mahuta to Graham, 31 July 1991, TC30 Vol. 13, OTS archive.

${ }^{167}$ Interview with Graham, 22 May 2011.

${ }^{168}$ ToWPU official 4 to Mike Ashby, 21 January 1992; ToWPU official 4, 22 January 1992; DoSLI official 1 to ToWPU official 4, 3 March 1992, TC30 Vol. 16 \& 19, OTS archive.
} 


\section{The return of Hopuhopu and hapū dissent}

Heta Tarawhiti of Waikato-Tainui hapū Ngāti Whawhakia had gifted the land at Hopuhopu to the Anglican Church in 1853 for educational purposes. The area was initially used to build a Church and school that local Māori children attended. Once the wars of the 1860s developed, the area was abandoned. The Anglican Church retained ownership until it was taken under the Public Works Act during World War II. When Waikato-Tainui began expressing an interest in having Hopuhopu returned to the iwi in the late 1980s, the Anglican Church supported their endeavour. The opposition to the return of Hopuhopu to the Tainui Māori Trust Board was from two separate parties. The descendants of Heta Tarawhiti sought the return of the land to the original owners' descendants. The other opponents of the return were conservative elements in the National Party. The Chairman of the Rotoiti branch of the National Party, Ross Baker, wrote to Prime Minister Jim Bolger demanding an explanation as to "why the Minister of Justice is giving the Hopuhopu military camp to the Tainui people?" Baker believed that Waikato-Tainui had rebelled in the 1860s and deserved punishment. In addition he pointed to the "full and final" settlement of 1946. A similar complaint was made in a letter to the Waikato Times regarding the return of Hopuhopu and in a letter to Doug Graham. Bolger replied to Baker that Waikato-Tainui's claims were valid and the return of Hopuhopu was an appropriate step to take in commencing negotiations. ${ }^{169}$

It was ultimately decided that Hopuhopu (and later Te Rapa) would be vested in Te Wherowhero, the first leader of the Kingitanga, to ensure that it could not be alienated. This stemmed from the previous historical experience of various Waikato-Tainui hapū who had

\footnotetext{
${ }^{169}$ DoSLI official 2 to Frame, 4 October 1990, TC30 Vol 9, OTS archive; AJ Clarke to Mahuta, 13 June 1991, RC Vol 5, Box 8, W-T archive; Kirsty Babbington, “Tainui Battle Took 100 Years,” Waikato Times, 7 September 1991, TC30 Vol.14 OTS archive; Jean Rhodes, "Hopuhopu Land Deal,” 7 September 1991, Waikato Times; Ross Baker to Jim Bolger, 1 September 1991; Bolger to Baker, 27 September 1991: all TC30 Vol.14, OTS archive; John Luten to Doug Graham, 28 July 1992, TC30 Vol 25, OTS archive.
} 
portions of confiscated land returned by the Compensation Court. Rather than return the land into tribal ownership, lands were returned to individuals who could sell their lands without hindrance. Most of the lands that were eventually returned to King Pōtatau following the opening of the King Country, were gradually sold by individuals during the late nineteenth and early twentieth century. Mahuta commented in a letter to Denese Henare: "This is what we are trying to stop by vesting the land in Te Wherowhero and then appointing custodial trustees to ensure that the land is never able to be alienated as it was previously." ${ }^{170}$ The desire by Waikato-Tainui negotiators to vest settlement assets into a collective structure reflected the aspirations of Waikato-Tainui to re-assert their rangatiratanga. The decision was made following consultation with the TMTB and Ngā Marae Toopu.

Mahuta wrote in a memorandum sometime in the middle of 1991 that the question of who or what the land would be vested in remained to be decided by the TMTB, with the input of the wider Waikato-Tainui community. Did they want the land in freehold fee simple title or under Māori Land title? What were the implications for any future development at Hopuhopu? Who would they register as the owner of Hopuhopu: “[The] Trust Board, Ngā Marae Toopu, [the] descendants of the original owners, Te Wherowhero?”171 Mahuta was going to seek a kaumatua hui to seek direction on these points. Mahuta's opinion on the issue of alienability was influenced by the research conducted at the Centre for Maaori Studies and Research (CMSR) at the University of Waikato of which he was the Director. Investigations of international experiences of Treaty settlement processes in Alaska, Canada and the United States strongly influenced his desire for inalienable title. The case of Alaska was an especially strong influence on his thoughts as not only had a number of academics based in Alaska such as Nicholas Flanders been research fellows at the CMSR, but Mahuta had also

\footnotetext{
${ }^{170}$ Mahuta to Henare, June 1993, RC Vol 30 1993, Box 11, W-T archives.

${ }^{171}$ Mahuta, "Hopuhopu and Te Wherowhero," 1 August 1991, RC Vol 5, Box 8, W-T archives.
} 
spent a semester teaching at the University of Alaska in $1985 .{ }^{172}$ Later when ToWPU asked Waikato-Tainui negotiators how people would receive benefits, Mahuta responded there would be a list of beneficiaries and that it would be up to individuals to make a choice of which of the 33 hapū they associated with. Mahuta hoped that it would "shake people out of their apathy" and emphasised later in a meeting with Crown officials that "as we suffered collectively so we should benefit collectively."173

Following debates within the Tainui Māori Trust Board the decision was made to vest Hopuhopu in the first King, Te Wherowhero. Waikato-Tainui negotiators wanted special legislation used to specifically vest Hopuhopu in Te Wherowhero because they were concerned that a vesting of land in an ancestor under the Māori Affairs Act 1953 was not possible. The CLO did not want to use special legislation and pressed for a vesting under the Māori Affairs Act. In November 1992 the Minister of Lands made an application to the Māori Land Court to vest Hopuhopu in Te Wherowhero. In December 1992 the Māori Land Court under Section 437 of the Māori Affairs Act vested Hopuhopu in Te Wherowhreo and the TMTB as "trustee for the benefit of the Waikato Tainui tribes" until a separate Trust had been established to own and manage the land. ${ }^{174}$

Despite the vesting made in late 1992 regarding the assets received from the Crown, the vesting of Hopuhopu was still being debated within Waikato-Tainui in mid-1993. By then the Crown had also offered to transfer to Waikato-Tainui the Te Rapa Air Base outside of

\footnotetext{
${ }^{172}$ Nicholas Flanders, "Lessons for the Māori from the Alaska Native Claims Settlement Act," undated \& Charles K. Ray (University of Alaska) to Mahuta, 10 May 1985: Alaska folder, W-T archives; Flanders, "The Alaska Native Corporation as Conglomerate: The Problem of Profitability,” Human Organisation, Vol. 48 Number 4, Winter 1989, 299-312.

${ }^{173}$ Shane Solomon, Meeting between Waikato-Tainui and ToWPU officials, 21-22 April 1994, RC Vol 33, Box 13, W-T archives.

${ }^{174}$ Berryman v Te Arikinui Te Atairangikaahu - Hopuhopu Military Camp and Te Rapa Airforce Base (1993), 18 Waikato Maniapoto Appellate MB 173.
} 
Hamilton. ${ }^{175}$ Two hapū, Ngāti Whawhakia and Ngāti Wairere, argued that since the Hopuhopu and Te Rapa military bases were located in their communities the land should be directly vested in them. Ngāti Whawhakia and Ngāti Wairere took their case to the Māori Appellate Court to attempt to halt the vesting of the land but they were rejected by the Court. The Court stated that “we accept that the Crown's intention was to return the lands as part settlement of the Tainui raupatu lands claim" and that "the settlement was with Tainui and not any individual hapū." ${ }^{176}$ The Court's decision reflected the government's preference for negotiating with larger groupings such as iwi rather than hapū, although the return of the settlement assets to hapū in theory may have been the best solution to effect rangatiratanga. ${ }^{177}$ Although the Māori Appellate Court approved the return of Hopuhopu to the iwi, it did not expressly approve of the use of the Māori Affairs Act to vest the Hopuhopu lands and the matter would remain unsettled for some time. ${ }^{178}$ The lack of substantial progress outside of the transfer of Hopuhopu (with its significant liabilities) and Te Rapa did little to help Mahuta's position from within Waikato and the liabilities and the negotiations increasingly sapped Waikato’s limited financial resources.

Waikato-Tainui advisor John Te Maru was optimistic that during the two previous years of "intense tribal debate” Waikato had reached the consensus that returned land should

\footnotetext{
${ }^{175}$ Berryman v Te Arikinui Te Atairangikaahu - Hopuhopu Military Camp and Te Rapa Airforce Base (1993), 18 Waikato Maniapoto Appellate MB 173.

${ }^{176}$ Berryman v Te Arikinui Te Atairangikaahu - Hopuhopu Military Camp and Te Rapa Airforce Base (1993), 18 Waikato Maniapoto Appellate MB 173, 3.

177 Joseph, "Unsettling Treaty settlements: Contemporary Māori Identity and Representation Challenges," 156160. It should be said that the practical difficulties of negotiating with the thousands of hapu throughout New Zealand also influenced the Crown's preferences.

${ }^{178}$ Ngāti Whawhakia and Ngāti Wairere later appealed the Māori Appellate Court's decision to the High Court in June 1995 and the issue was not settled until the passing of settlement legislation that finally formally vested the lands in Te Wherowhero in late 1995: Ngapare Hopa to Graham, 28 November 1994, TC30 Vol.40, OTS archive; "Hopuhopu and Te Rapa," 27 June 1995, RC SS June to September 1995, Box 39, W-T archives; Bill Patterson to Graham, 22 September 1995 \& Mahuta to Graham, 25 September 1995, both: June to September 1995, Box 19, W-T archives; Graham to Mahuta, September to October 1995 (SS) Box 40, W-T archives.
} 
be vested in Te Wherowhero to ensure that the properties could never be alienated. ${ }^{179}$ Mahuta informed the Crown that the delays in reaching a settlement had severely corroded the robustness of the TMTB's mandate alluding to the challenges in the Māori Appellate Court from Ngāti Whawhakia and Ngāti Wairere dissidents. ${ }^{180}$ In internal hui Mahuta stated that it was the Crown’s delays which had delayed Waikato-Tainui’s wider negotiation process. ${ }^{181}$

\section{The politics of delays and policy development}

The return of Hopuhopu and Te Rapa dominated the negotiations as the Crown developed a strategy to tackle the larger claims such as Waikato-Tainui and Ngāi Tahu from 1991-1994. At the second formal meeting of Waikato-Tainui and the National government in February 1992, Graham stated that he wanted time to consider Waikato's land for land principle and "a strategy for selling it to his Cabinet colleagues." Graham stressed that he understood that the land for land principle was the centre of Waikato's demands and that a way could be found to accommodate both Waikato and the general public. First, the Crown needed to find out what land and assets it held on its own balance-sheets. The Crown was still uncertain of exactly what it owned. Graham commented during the meeting: "Where will both the Crown and Waikato end up from the honour point of view? What is the obligation of the Crown? To what extent should the Crown assist Waikato to have an economic base to provide for its own future?”182 The fundamental premise of the negotiations was still clearly being developed mid-way through the process. Mahuta commented quite bluntly in an internal memorandum: "For all of us on the negotiating team I know it is frustrating during

\footnotetext{
${ }^{179}$ John Te Maru, “Hopuhopu and Te Rapa,” 23 September 1993, RC Vol 32, Box 12, W-T archives; Brent Wheeler to ToWPU official 4, 22 November 1993, RC Vol 32, Box 12, W-T archives.

${ }^{180}$ Solomon and Henare memorandums: RC Vol 33, Box 13, W-T archives; Meeting between Crown and Waikato negotiators, 14 April 1994, AAKW W5105 7812 22, Archives NZ; Mahuta to Graham, 10 February 1993, RC Vol 30 1993, Box 11, W-T archives, 1.

${ }^{181}$ Meeting of the Tainui Māori Trust Board, 16 May 1992, RC Vol 11 1992, Box 11, W-T archives;; Brent Wheeler to ToWPU official 4, 22 November 1993, RC Vol 32, Box 12, W-T archives.

${ }^{182}$ Meeting between Crown and Waikato negotiators, 21 February 1992, TC30 Vol. 18-19, OTS archive;
} 
these sessions when the Minister flies off on a tangent and wants to discuss everything but what is on the agenda. I take it from what he is saying, however, that regardless of what the facts may reveal any final decision is going to be 'political' rather than being based on what is fair to Waikato.”183

Graham and sympathetic Ministers (such as Prime Minister Bolger and Minister of Fisheries and Māori Affairs, Doug Kidd) and officials were in a difficult situation as they were treading completely new ground with the development of a Treaty settlement policy. In addition, the lengthy review and set of intra-governmental debates were very much a byproduct of the painfully slow speed at which governments often work and review policy especially. For Waikato-Tainui there was no true alternative to negotiating directly with the Crown, other than waiting for a Tribunal hearing, and following that hearing negotiations would still be the only option. As Mahuta stated at a hui, "It was the only game in town." 184 As a result of the general delay in the negotiation process, Waikato-Tainui's advisors were also put under considerable pressure internally by some factions within Waikato-Tainui. As 1992 ended Waikato-Tainui negotiators and beneficiaries were becoming increasingly frustrated with what they saw as the glacial pace of negotiations. ${ }^{185}$ Commercial advisor Brent Wheeler attempted to explain in a letter to Pumi Taituha, a kaumatua and member of the Tainui Māori Trust Board, that the slow pace of the negotiations was largely a result of "poor understanding of the issues" and because the machinery of government is extremely slow. "In addition government reforms of C[rown]R[esearch]I[institute]s, health care and education have had to be prevented from dwindling the Crown's assets in the raupatu rohe.” Other than the proposed transfer of Hopuhopu, in many ways the Waikato-Tainui

\footnotetext{
${ }^{183}$ Mahuta to Nga Marae Toopu, 24 February 1992, RC Vol 29, Box 11, W-T archives.

184 Meeting of the Tainui Māori Trust Board, 4 July 1992, RC Vol 11 1992, Box 11, W-T archives.

185 One set of caricatures by an unknown Waikato-Tainui advisor depicted Mahuta as a bulldog, frothing at the mouth-clearly someone who was aggressive and trying to push forward the negotiations. Graham was depicted as a snail, stretching things out and going at a very slow pace. Interview with Shane Solomon, 28 May 2011.
} 
negotiations had not advanced during 1992 and the criticisms internally were building. By international standards progress was being made quickly, but the Waikato-Tainui negotiators and the people themselves had been waiting for many years. Some Waikato-Tainui negotiators had been involved in the 1984 Hikoi ki Waitangi; others had been in the battle over the Huntly Power Station in the 1970s and other events before that. ${ }^{186}$ The perception of progress was certainly relative.

The concern amongst Waikato-Tainui negotiators of the slow pace of the negotiations was greatly heightened as the 1993 elections neared. Mahuta believed that the Crown had "adjourned the negotiations by its inaction...Until the Crown sorts out its own position all Maaori claimants will suffer the frustrations that our people are currently experiencing." Mahuta’s opinion had not softened anymore by the very end of 1993. "Either the rules are secret or there are no rules at all and the participants are forced to make them up as they go or respond to announced changes in game plan because of other players with undisclosed intentions...No private sector corporate could survive processes so convoluted, procrastinatory and demanding as these are.”187 Mahuta was referring to the role that key players in government could have on the negotiations, such as Treasury and the Minister of Finance especially. Mahuta's comments reflected the difficulty of engaging in negotiations with no concrete system in place to govern the process.

As 1993 ended one of Waikato-Tainui's principal commercial advisors, Brent Wheeler, sent a letter to ToWPU officials expressing Waikato-Tainui's disappointment with the state of the negotiations at the end of another frustrating year. "We note that given

\footnotetext{
${ }^{186}$ Robert Macdonald, The Fifth Wind, (Auckland: Hodder \& Stoughton, 1989); Robert Mahuta, "Tainui, Kinnitanga and Raupatu."

${ }^{187}$ ToWPU official 4 to Graham, 3 October 1993, AAKW W5105 7812 22, Archives NZ; Mahuta to Graham, 28 September 1993, RC Vol 32, Box 12, W-T archives; M Roderick, "Land claim talks 'stalled'”, New Zealand Herald, 7 December 1993.
} 
uncertainties about the mode and practicalities of government over the coming period, there may be some difficulties in formulating and implementing policy expeditiously." The Crown always stated during the negotiations that it refused to adopt a piece-meal approach to compensation or the return of land, and instead vied for swift resolution that was full and final. The slow rate of progress had considerably dampened the enthusiasm of the wider Waikato-Tainui community. ${ }^{188}$ As 1994 began, Waikato-Tainui negotiators did not perceive that the two parties were any closer to an agreement than they had been when negotiations began with National in 1991.

${ }^{188}$ Brent Wheeler to ToWPU official 4, 22 November 1993, RC Vol 32, Box 12, W-T archives. 


\section{Part II: Ngāi Tahu's negotiations with the Fourth Labour Government and Fourth National Government}

\section{Waitangi Tribunal hearings and the development of the first land-bank}

In August 1986 Henare Rakiihia Tau on behalf of the Ngāi Tahu Māori Trust Board submitted a claim to the Waitangi Tribunal about the government's announcement to transfer Crown land interests to State-Owned Enterprises. Over the following year and a half seven further amendments to their statement of claim were made that set out Ngāi Tahu's grievances arising from land purchases and the lack of reserves provided by the Crown, and the loss of access to food gathering areas (mahinga kai) including both sea and inland fisheries. ${ }^{189}$ Tau was the Deputy Chairman of the Ngāi Tahu Māori Trust Board. Tau was the head (upoko) of the Ngai Tuahuriri hapū of Ngāi Tahu based around Tuahiwi Marae near Kaiapoi outside of Christchurch. Tipene O’Regan was the Chairman of the Ngāi Tahu Māori Trust Board, and he and Tau formed an effective partnership in leading the Ngāi Tahu claim in the 1980s. O’Regan was also the Chairman of the Mawhera Incorporation, a Ngāi Tahu landowners trust on the West Coast of the South Island that was established in $1976 .{ }^{190}$ From August 1987 to October 1989 the Ngāi Tahu claim was heard by the Waitangi Tribunal.

At the conclusion of Ngāi Tahu’s Waitangi Tribunal hearings in October 1989 the Presiding Officer Judge Ashley McHugh expressed concerns with the continuing alienation of Crown land in the South Island. Following the Tribunal hearings Tau and O’Regan brought the Presiding Officer's comments to the attention of the Crown and asked that a system be established where the Ngāi Tahu Māori Trust Board would be consulted before any Crown land was alienated. ${ }^{191}$ By mid-December 1989 the Solicitor-General and Acting

\footnotetext{
${ }^{189}$ Waitangi Tribunal, The Ngāi Tahu Report, 3-10.

${ }^{190}$ Ann Parsonson, “The Whale that Awoke,” 257.

191 Judge Ashley McHugh, “Concluding Remarks,” 10 October 1989; David Palmer to Minister of Lands Peter Tapsell: C-27-4-02 Vol. 1, OTS archive.
} 
Deputy-Director General of Lands, following discussions with Tau Senior and O’Regan, proposed an early warning system (or land-bank) under which the Ngāi Tahu Māori Trust Board would be notified prior to the alienation of Crown land in the Ngāi Tahu rohe. The system originally was confined to Department of Lands Crown land but the Acting Deputy Director-General of Lands stated to O’Regan that he hoped that other Crown agencies would also become subject to the system. If the Crown land was not subject to offer-back requirements under the Public Works Act 1981, a representative of the Ngāi Tahu Māori Trust Board (NTMTB) was informed of the pending sale. ${ }^{192}$ The NTMTB would then have to decide whether it wanted to retain the land as part of a future settlement. O’Regan sought a blanket ban on the sale of all Crown land in the Ngāi Tahu rohe but he understood that the early warning system was a fair compromise. The Crown provided funding for the NTMTB to employ a specialist to aid the Trust Board in its selection of properties for inclusion. ${ }^{193}$

The Commissioner of Crown Lands was tasked with coordinating the system in 1990 (its first year of operation) and encountered some difficulties. One of the issues related to government departments ignoring the new directive to warn a third party, the Ngāi Tahu Māori Trust Board, before disposing of their surplus assets. There was also a fear that government Departments would not be compensated for the loss of revenue from the sale. Eventually a Cabinet directive was developed to refund to individual departments and SOEs the loss of revenue from placing Crown properties in Ngāi Tahu's land-bank, and later other

\footnotetext{
${ }^{192}$ Public Works Act 1981, Section 40: When land taken under the Public Works Act was no longer required for a public purpose, Section 40 of the Act provided an offer-back mechanism to the previous owner for purchase. 193 DoSLI official 3 to David Palmer, 14 December 1989; O’Regan to Tapsell, 15 December 1989; Tapsell to O’Regan, 20 December 1989; Tapsell to Geoffrey Palmer, 20 September 1989: C-27-4-02 Vol.1, OTS archive.
} 
land-banks. Departments and SOEs were paid full market value for the properties by the Ministry of Justice. ${ }^{194}$

\section{Fourth National Government: Negotiations with Ngāi Tahu}

By the time the main Ngāi Tahu report was released in early February 1991 the size of ToWPU had marginally increased but the coordination of Treaty policy was very difficult across the different Crown agencies and departments, despite the fact that the Crown Task Force on Treaty of Waitangi Issues met regularly. The general thrust of the report was accepted by both the Crown and Ngāi Tahu as a basis for the negotiations. Each had their problems with some of the Tribunal's findings but agreed to set their disagreements aside during the negotiations. ${ }^{195}$ The report was the largest and most comprehensive report produced by the Tribunal at that time. Its analysis was extended past the middle of 1991 as officials from the CLO, Treasury, Manatu Māori, and the Department of Conservation (DoC) became involved in its examination. ${ }^{196}$ Ngāi Tahu's negotiations formally began in September 1991, seven months after the Waitangi Tribunal’s Ngāi Tahu Report was released.

Monthly meetings were held until the negotiations broke down in mid-1994. These meetings were very formal gatherings led by each side’s main negotiator, Tipene O’Regan for Ngāi Tahu and Graham for the Crown. They were similar in structure to Waikato-Tainui’s negotiations with the Crown. The named claimant for Ngāi Tahu’s Waitangi Tribunal claim,

\footnotetext{
${ }^{194}$ DPMC official 1 to Prime Minister's Private Secretary, 3 November 1989; Commissioner of Crown Lands, “The Ngāi Tahu Consultative Process,” December 1989; STA (91) M 19/5; ECC (91) M 38/1; CAB (91) M 27/10: all C-27-4-02 Vol.1, OTS archive.

${ }^{195}$ Minutes of a Meeting between Ngāi Tahu and Crown Negotiators, 18 September 1991, C-27-8-01 Vol. 4, OTS archive; Framework Agreement between Ngāi Tahu and the Crown, 27 November 1991, C-27-2-02 Vol. 3, OTS archive.

${ }^{196}$ Treasury official 6 to ToWPU official 5, "Proposed Plan of Action for Dealing with Waitangi Tribunal's Ngāi Tahu Report," 17 April 1991; Treasury official 3 to ToWPU official 5, "Ngāi Tahu - Action Plan,” 24 April 1991; Treasury official 3 to ToWPU official 5, "Ngāi Tahu - Proposed Plan of Action,” 26 April 1991; CAB (91) M 19/22; ToWPU official 6, "Ngāi Tahu Negotiations - Interim Synthesis Report," 2 September 1991 all C-27-8-01 Vol. 4, OTS archive.
} 
Henare Rakiihia Tau Senior, was a co-negotiator. Nick Davidson was appointed as Ngāi Tahu's lead legal consultant when Paul Temm stepped aside after acting as lead counsel for Ngāi Tahu during the Tribunal Hearings. Davidson was a prominent lawyer from the law firm Bell Gully Buddle Weir. A commercial development consultant, Stephen Jennings, was also appointed. Jennings was an economist for investment bank Credit Suisse First Boston and formerly worked for the Treasury. The Secretary of the Ngāi Tahu Māori Trust Board (NTMTB), Sid Ashton, also played a prominent officials level role for Ngāi Tahu. ${ }^{197}$ Ashton had been the Secretary of the NTMTB since the mid-1970s and played an active role in Ngāi Tahu’s Waitangi Tribunal hearings in the late 1980s. The Crown's A Team consisted of Graham and Secretary of Justice David Oughton. The B Team initially was made up of a diverse array of officials from various different government departments and headed by ToWPU. ${ }^{198}$ Dozens of officials would come and go during the negotiations, the only constant on the Crown's side throughout was Graham. ${ }^{199}$

There were a number of specific redress issues to address in Ngāi Tahu's negotiations for which the Tribunal had made recommendations: Ngāi Tahu management and ownership of Whenua Hou (Codfish Island), the return of pounamu, the Arahura Valley, the Crown Titi Islands, Lake Waihora and many other specific sites. The negotiations regarding the extent of financial compensation (which will be explored in detail in Chapter 2); and lands contained in Ngāi Tahu's land bank (some of which will be explored in Chapter 3) were also prominent on-going issues during the first three years of negotiations from 1991-1994. While those issues were pressing and began to be addressed early in the negotiations, the first major issue on the table for Ngāi Tahu was the creation of a legal entity that would enable Ngāi Tahu

\footnotetext{
197 “Ngāi Tahu Annual Hui, 22-24 November 1991,” NT140 M14 @), MB archive.

198 “Crown Negotiating Team for the Ngāi Tahu Claim,” 11 September 1991, NE-12-027-00-02 Vol. 1, OTS archive.

${ }^{199}$ Davidson, “Lunch with [TPK official 1],” 13 February 1996, Vhi 48 (j), TRONT archive.
} 
control over Ngāi Tahu affairs. The Ngāi Tahu Māori Trust Board structure that had been in place since their 1944 settlement was viewed as impinging on Ngāi Tahu’s rangatiratanga, because it was accountable to the Crown rather than to the Ngāi Tahu people and marae.

\section{The establishment of Te Rūnanga o Ngāi Tahu and rangatiratanga}

The drive to establish an entity that had a legal personality in the late twentieth century stemmed from the desire for a rūnanga-based organisation. As Te Maire Tau has noted, "Ngāi Tahu's response to the loss of land was to organise themselves into hapū and village rūnanga." These rūnanga sought redress from the government and organised themselves to tackle what would become known by the early twentieth century as the Ngāi Tahu claim, Te Kereme. ${ }^{200}$ Marae across the large Ngāi Tahu region worked together but there was no unifying structure due to a lack of funding. The 1920 Native Land Claims Royal Commission chaired by Robert Noble reported on only one of the eight purchases that took place from 1844-1864, Kemp’s purchase. ${ }^{201}$ The Commission recommended £354,000 as compensation and in 1928 the Ngaitahu Trust Board was established to receive the funds. It was not until 1944, when the Ngāi Tahu Claim Settlement Act was passed, that Ngāi Tahu were allocated $£ 10,000$ annually over a thirty year period or a total of $£ 300,000$. The settlement spurred the creation of a centralised Ngāi Tahu structure, the Ngāi Tahu Māori Trust Board. ${ }^{202}$ The 1946 Ngāi Tahu Trust Board Act authorised the Board to administer the funds received in the 1944 settlement but it was limited in its recognition of Ngāi Tahu rangatiratanga. The Board, like all other Maori Trust Boards of the time, would ultimately be accountable to a Minister of the Crown rather to the members of Ngāi Tahu. In 1955 the Ngāi

\footnotetext{
${ }^{200}$ Te Maire Tau, "Ngāi Tahu - From ‘Better Be Dead and Out of the Way’ to 'Be Seen and to Belong,'” 228.

${ }^{201}$ In 1848 Henry Tacy Kemp, acting in the role of Crown Land Purchasing Officer, purchased approximately 20 million acres of land in present-day Canterbury and provided only miniscule reserves to Ngāi Tahu: Waitangi Tribunal, Ngäi Tahu Report, 51-82, 387-524.

${ }^{202}$ Te Maire Tau, "Ngāi Tahu - From 'Better Be Dead and Out of the Way' to 'Be Seen and to Belong,”' 229234.
} 
Tahu Trust Board Act was repealed and replaced with the Māori Trust Boards Act that applied Ngāi Tahu (and Waikato-Tainui)'s Trust Board structure to some Māori groups around the country. By the early 1980s members of the Ngāi Tahu Māori Trust Board considered developing a governing structure that would incorporate input from Ngāi Tahu rūnanga. ${ }^{203}$

Due to growing dissatisfaction within Ngāi Tahu with the Trust Board structure and as a precursor to a more robust legal personality, some members advocated forming an Incorporated Society of Rūnanga at a hui at Arowhenua in 1988. By the end of 1989 an Incorporated Society, Te Rūnanganui o Tahu, came into being. Its charter stated that the purpose of the body was "to protect, to advance, to develop and to unify the interests of Ngāi Tahu in the true spirit of tino rangatiratanga implicit in the Treaty of Waitangi." ${ }^{204}$ It operated separately but in concert with the Ngāi Tahu Māori Trust Board.

In 1990 the Labour government passed the Rūnanga Iwi Act that provided established tribal authorities with extensive governing powers. It was shortly thereafter repealed by the new incoming National government because it was claimed that too many Māori people had severed their connections with their respective iwi and as such the tribal authorities would not be representative of the majority of Māoridom. Ngāi Tahu was firmly opposed to its repeal, noting that it had given some recognition of tino rangatiratanga for Māori. Ngāi Tahu believed that those aspects should not be repealed, rather the Rūnanga Iwi Act should be amended. After the repeal of the act, the Waitangi Tribunal and the Court of Appeal noted the lack of recognition by the Crown of a legal personality for Ngāi Tahu and that recognising their legal personality would go some way towards restoring the guarantee of tino

\footnotetext{
${ }^{203}$ Stephanie Kelly, "The Ngāi Tahu Māori Trust Board", University of Canterbury, MA Thesis, 1991, 36. ${ }^{204}$ Crofts, Charles, "Kaiwhakahaere Report", Ngāi Tahu Māori Trust Board Annual Report, 1996, 26-27, TRONT archive.
} 
rangatiratanga which was inherent in the signing of the Treaty. ${ }^{205}$ Ngāi Tahu's desire for a legal personality was to ensure that it had full control of their own social and economic affairs following settlement unlike the previous Māori Trust Boards which had been subservient to the Crown. ${ }^{206}$ The Ministerial control of the Māori Trust Boards was so strong that the Boards were unable to spend \$200 without the Minister’s approval. ${ }^{207}$ Ngāi Tahu sought a rūnanga-based organisation. Ngāi Tahu leaders would be accountable first and foremost to their rūnanga, marae and the whanau of Ngāi Tahu, rather than the Crown.

In a mid-1991 memorandum to Doug Graham regarding the issue of Ngāi Tahu's legal personality, O’Regan stressed that the issue was extremely important in terms of not only fulfilling the Crown's need to recognise Ngāi Tahu's tino rangatiratanga but providing a legal personality would also address what O’Regan referred to as the Crown's oft-cited nightmare of successive Ngāi Tahu generations returning to re-assert their claim. Unlike the early Waikato-Tainui negotiations that were dominated by full and final discussions regarding the 1946 Waikato-Maniapoto Māori Claims Settlement Act, Ngāi Tahu’s negotiations did not address the spirit or intent of their 1944 settlement. This may have been as a result of both the Tribunal's finding that the 1944 settlement was very limited in its scope and terms of reference, and the Crown's earlier experience with the issue during Waikato-Tainui's negotiations in 1989 and 1990. By enabling Ngāi Tahu to have stronger control of its fate in any post-settlement situation, O’Regan stated, the settlement would have a strong sense of

\footnotetext{
${ }^{205}$ Hill, Māori and the State: Crown-Māori Relations in New Zealand/Aotearoa 1950-2000, 241-43; Tipene O’Regan, "Submission to the Repeal of the Runanga Iwi Act 1990,” C-27-2-04 Vol. 1, OTS archive; Waitangi Tribunal, The Ngāi Tahu Claim: Supplementary Report on Ngāi Tahu Legal Personality (Wellington: GP Books, 1991).

${ }^{206}$ Tipene O’Regan, “The Ngāi Tahu Claim,” in Waitangi (ed.) Hugh Kawharu (Auckland: Oxford University Press, 1989), 259.

${ }^{207}$ Gabrielle Huria, "The Bill: Ngāi Tahu putting a stamp on our identity and tribal rights,” Te Karaka, Raumati/Summer 1996, 6.
} 
finality. Ngāi Tahu emphatically did not want to follow the problematic post-settlement situations that had developed internationally. ${ }^{208}$

As the negotiations began in September 1991 Ngāi Tahu indicated to the Crown that the establishment of their legal personality was a key starting-point for the negotiations. A draft of a bill to recognise Ngāi Tahu's legal personality was sent to the iwi on 8 November 1991 and was reviewed by the Ngāi Tahu team. Ngāi Tahu recommended significant revisions. There was clearly some Crown discomfort with the use of the term rangatiratanga as Ngai Tahu had recommended the "Ngāi Tahu Rangatiratanga Recognition Bill.” Manatu Māori officials had changed the name of the bill to the "Ngāi Tahu Bill.” Ngāi Tahu's legal advisor, Nick Davidson, affirmed that the title contained the term rangatiratanga for a specific purpose, and that its meaning was quite literal and necessary for the bill. The recitals formed a key part of the legislation as they canvassed the historical basis for the legislation. The recitals were a condensed history of Ngāi Tahu's attempts to have its rangatiratanga recognised over the years. The Crown had completely omitted the recitals from the first draft of the bill. Davidson believed the recitals were necessary to place the bill in its historical perspective. $^{209}$

In the next draft of the bill Manatu Māori had still not inserted rangatiratanga into the title, without explanation. Davidson wrote to both the Secretary of Justice and to the Manatu Māori official that the changes that he had provided the week before were absolutely necessary. While some recitals had been inserted, they had only a bare resemblance to the recitals originally provided by Ngāi Tahu. Graham advised Manatu Māori that while Ngāi Tahu continued to assert that the term rangatiratanga was necessary in the recitals, title and

\footnotetext{
${ }^{208}$ O’Regan to Graham, 30 June 1991, C-27-2-04 Vol. 1, OTS archive.

${ }^{209}$ Winston Peters to Graham, 2 August 1991 \& Nick Davidson to Manatu Māori official 1, 13 November 1991: both C-27-2-04 Vol. 1, OTS archive.
} 
purpose of the bill, he had convinced Ngāi Tahu to agree subsequently that the term kawanatanga also had to be included as a quid pro quo. A reference to Article I and Article II of the Treaty of Waitangi would then be the best vehicle for this. ${ }^{210}$

The Crown Law Office (CLO) too was particularly concerned with the use of the term rangatiratanga in the proposed legal personality bill. The Crown had been arguing throughout all of its Court proceedings with Māori claimants that it was the executive and not the Courts which could alone determine Treaty policy. One CLO official feared that by guaranteeing tino rangatiratanga to Ngāi Tahu within its rohe it would challenge the Crown in the Courts over the use and ownership of resources. With the recent support from the Courts for some Māori claimants the CLO feared that it would be best to oppose the use of the term rangatiratanga. CLO noted further that the Tribunal had not recommended that the Crown recognise Ngāi Tahu's rangatiratanga specifically through legislation so that it was not necessary in this way. Although the Crown could, and at times did, ignore the Waitangi Tribunal's recommendations, it could also use the Tribunal's recommendations to its own advantage when necessary. CLO believed that the establishment of a legal personality was possible without the use of the term rangatiratanga. ${ }^{211}$

Another CLO official had a similar opinion. She also felt that Ngāi Tahu's proposed bill went far beyond what was necessary for establishing Ngāi Tahu's legal personality. Once again the use of the term rangatiratanga was of particular concern and she stressed that there were not only legal implications but also constitutional ones. By affirming Ngāi Tahu's rangatiratanga it was feared that the Crown would be interpreted by the Courts as giving Ngāi Tahu the right to regulate its own laws and justice system and that this would create serious

\footnotetext{
${ }^{210}$ Nick Davidson to David Oughton \& CLO official 1, 20 November 1991, C-27-2-04 Vol. 1, OTS archive; Graham to TPK official 2, 21 November 1991, C-27-2-04 Vol. 1, OTS archive.

${ }^{211}$ CLO official 2 to Graham, 25 November 1991, C-27-2-04 Vol. 1, OTS archive.
} 
constitutional issues. While she stressed that she understood that the Crown should not be seen as imposing upon Ngāi Tahu in any way there needed to be some accountability measures in place. The notion of the "principles of the Treaty of Waitangi" had come under some criticism by government MPs and thus she thought that the term rangatiratanga would face even more opposition. At their monthly meetings until the end of $1991 \mathrm{Ngāi}$ Tahu negotiators stressed that the inclusion of direct references to rangatiratanga were necessary in their legal personality legislation, and especially the reference to Article II of the Treaty of Waitangi in Te Reo Māori. ${ }^{212}$

The Solicitor-General, JJ McGrath, was concerned about including a term such as "rangatiratanga" in legislation when there had not been an agreed definition of the word by both negotiating parties. The Solicitor-General, supported by ToWPU officials, recommended a consultation between the Crown and Māoridom to determine the definition of "rangatiratanga" with much the same structure as the negotiating process. In this way a proper definition could be found. A ToWPU official noted the Solicitor-General's desire for a consultation to provide a concrete definition of the term "rangatiratanga" and supported the idea. She did note, however, that "in regard to the precedent effect of an agreement between the Crown and Ngāi Tahu on this matter, it must be noted that Ngāi Tahu's meaning of rangatiratanga may not accord with views held by other iwi." 213

After having met with Graham on 4 December 1991 O’Regan sought to address the Crown's concerns with Ngāi Tahu's draft bill. Crown officials' concerns regarding “justiciability and 'self-government” would be addressed by deleting the first part of the long title to the Bill, which had read: “To recognise the tino rangatiratanga of Ngāi Tahu Whānui."

\footnotetext{
${ }^{212}$ CLO official 3 to ToWPU official 7, 25 November 1991, C-27-2-04 Vol. 1, OTS archive; "Meeting between Crown and Ngāi Tahu Negotiators," 27 November 1991, C-27-2-03 Vol.1, OTS archive.

${ }^{213}$ JJ McGrath to Graham, 6 December 1991; ToWPU official 7 to David Oughton, 9 December 1991: both C27-2-04 Vol. 1, OTS archive, 1.
} 
Also deleted would be one of the recitals which stated that "Ngāi Tahu asserts that its tino rangatiratanga resides in its papatipu rūnanga represented in Te Rūnanganui o Tahu Incorporated.” O’Regan stressed that while the two passages above could be removed, they could not delete the first two recitals which stated that "the tino rangatiratanga of Ngāi Tahu existed prior to Ngāi Tahu signing the Treaty of Waitangi in 1840" and "the Treaty of Waitangi confirmed and guaranteed the tino rangatiratanga of Ngāi Tahu" because Ngāi Tahu could not have signed the Treaty of Waitangi if it did not hold tino rangatiratanga over the land and its people. He stated further that it was a fact that the Treaty of Waitangi confirmed and guaranteed the tino rangatiratanga because it stated so in the Māori version of the Treaty of Waitangi. O'Regan also wondered whether a more "bare bones" piece of legislation could address their legal personality or if a deed between Ngāi Tahu and the Crown could be executed which acknowledged Ngāi Tahu's rangatiratanga outside of Parliament and would therefore be non-justiciable. Graham informed O'Regan that the legal personality bill would not be introduced to Parliament before the end of the year. The Crown was still concerned regarding the use of the term "rangatiratanga" and felt that it would need to be discussed with Crown Law and Parliamentary Counsel. ${ }^{214}$

A special meeting was arranged in February 1992 to focus on the development of Ngāi Tahu's legal personality legislation and specifically the term rangatiratanga but its inclusion was repeatedly rejected by Te Puni Kōkiri (TPK), in addition to the CLO. According to Ngāi Tahu advisor Nick Davidson, TPK's views on the matter were the only negative reactions to Ngāi Tahu's proposals at the special meeting, not the CLO. TPK officials contended that there was no way to specifically define rangatiratanga whereas Ngāi Tahu negotiators stressed that Ngāi Tahu would have its own way of defining rangatiratanga.

\footnotetext{
${ }^{214}$ O’Regan to Graham, 11 December 1991 \& Graham to O’Regan 17 December 1991: C-27-2-04 Vol. 1, OTS archive; "Minutes of 4 February 1992 meeting between Ngāi Tahu and the Crown," C-27-8-01 Vol. 1, OTS archive.
} 
Its definition was not contingent on acceptance by all Māoridom. Later in the meeting the same TPK officials were also reported as emphasising that Māori participation in conservation and management decisions should be kept to a minimum. ${ }^{215}$ At the regular monthly March 1992 meeting between the Crown and Ngāi Tahu the CEO of TPK, Wira Gardiner, reported that due to staff turnover at the Ministry little work had been completed on Ngāi Tahu's legal personality legislation. ${ }^{216}$ By the third and fourth draft of the legal personality bill there was not a single reference to rangatiratanga contained in the recitals or in the bill. ${ }^{217}$ It would be another four years until Ngāi Tahu's legal personality was recognised by Parliament. This delay stemmed largely from the internal dissention within Ngāi Tahu, coupled with the stalling power of the Parliamentary Select Committee process.

\section{Internal opposition from Waitaha, Tuhuru and Ngāti Mamoe}

It was in early 1992 that internal opposition to Ngāi Tahu negotiators began to manifest itself. ToWPU began to receive letters from dissident groups within some hapu from the West Coast of the South Island and Southland—identifying themselves as Ngāti Mamoe, Tuhuru and Waitaha-who claimed that the Ngāi Tahu Māori Trust Board had not involved them in discussions over the development of a legal personality. ${ }^{218}$ O'Regan was concerned that after going through all the trouble of fighting off external challenges, Ngāi Tahu would now have to combat constant internal challenges. He predicted that the Crown would not

\footnotetext{
${ }^{215}$ One of Ngāi Tahu's advisors mused: "How do these people live with themselves?" To be fair the officials were acting in the role of public servant so maybe that advice was expected of them. Nick Davidson, "Vogel House Meeting,” 10 February 1992, Vh 12 (c) Box 150, TRONT archive.

216 "Minutes of 1 March 1992 meeting between Ngāi Tahu and the Crown," C-27-8-01 Vol. 1, OTS archive.

217 “Draft Legal Personality Bill,” 25 February 1992, C-27-2-04 Vol. 2, OTS archive; Davidson to O’Regan, 28 February 1992, Vhi 12 (g) Box 150, TRONT archive.

${ }^{218}$ ToWPU official 4 ToWPU official 6 file notes, February and March 1992, C-27-2-04 Vol. 2, OTS archive. Tuhuru and Waitaha were also challenging the allocation of fisheries quota. See Tipene O'Regan, "Old Myths and New Politics: Some Contemporary Uses of Traditional History,” New Zealand Journal of History, 26(1), April 1992.
} 
negotiate if that dissent existed. ${ }^{219}$ "I believe that the Government would run a mile from recognition of Ngāi Tahu if there was open internal dispute. Indeed, there is grave danger that a settlement could not be achieved by Ngāi Tahu with these parties rampaging through the process - leaving aside the legal personality legislation." ${ }^{220}$ Up until this point, the Crown was negotiating with who it thought were the recognised leaders of the tribe. The issue of internal dissention only starts to be an issue when these objections began to be raised. Subsequently the Crown begins to state openly that it will only negotiate with the larger group, and that it is for the iwi to sort out their internal problems.

The representative for Tuhuru, Eli Weepu, contacted Graham and ToWPU officials to request legal personality legislation for Ngāi Tahu on the West Coast, "Tai Poutini Tangata Whenua."221 Tuhuru had a competing view of rangatiratanga and believed that the Ngāi Tahu leadership had undermined their autonomy. They rejected Ngāi Tahu's mandate to negotiate for them. ${ }^{222}$ In August 1992 lawyers for Tuhuru contacted the NTMTB to notify them that they would be taking their case to the Māori Land Court (MLC) to determine the issue of mana whenua on the West Coast. Their case was rejected by the MLC. ${ }^{223}$ Tuhuru then turned to the Waitangi Tribunal and requested an urgent hearing regarding the legal personality legislation but their claim did not meet the criteria for urgency. ${ }^{224}$ NTMTB representatives reported back to the iwi that the legal personality bill had been presented to hapū around the South Island and North Island at ten hui and that other than some Ngāti Mamoe, Tuhuru and

\footnotetext{
219 O’Regan to Negotiating Team, 27 January 1992, MB Archives.

${ }^{220}$ O’Regan to Negotiating Team, 17 January 1992, Vhi 9B (k), TRONT archive.

${ }^{221}$ Eli Weepu to Graham and ToWPU official 3, 9 March 1992, C-27-2-01 Vol. 2, OTS archive.

${ }^{222}$ Te Runanga o Tuhuru to Doug Kidd [Minister of Māori Affairs], 22 May 1992; ToWPU official 7 to O’Regan, 27 July 1992: C-27-2-01 Vol. 2, OTS archive.

${ }^{223}$ Mohammed Shabadet to Charles Crofts, 25 August 1992, NT140 Mi (u), Macmillan Brown archives

${ }^{224}$ Edward Taihakerei Durie to Tuhuru, 22 December 1992, C-27-2-01 Vol. 2, OTS archive. Tuhuru attempted to submit a claim for urgency again in mid 1994: ToWPU official 8 to Graham, 8 June 1994, C-27-2-02 Vol. 3, OTS archive.
} 
Waitaha critics it had been received well. ${ }^{225}$ The first hui was held in Hokitika but those Tuhuru opposed to the Ngāi Tahu negotiators did not appear. ${ }^{226}$ At the annual Ngāi Tahu huia-tau (annual meeting) held at Kaikoura marae in November 1992, a large majority supported the introduction of the Te Rūnanga o Ngāi Tahu Bill to Parliament. ${ }^{227}$ The Crown's position on Tuhuru was that Ngāi Tahu negotiators had a mandate to negotiate, and they expressed their preference for iwi negotiators in meetings with Ngāi Tahu. ${ }^{228}$ A paper was prepared by ToWPU for Cabinet in early September 1992 which sought permission to introduce legislation regarding Ngāi Tahu's legal personality. The paper stressed that the legislation would provide some certainty to the Crown regarding who it was engaged in negotiations with and a sense of finality to the settlement. ${ }^{229}$

Internal opposition from some Ngāi Tahu hapū effectively delayed agreement on Ngāi Tahu’s legal personality. This opposition was assisted by Ngāi Tahu MPs Sandra Lee and Whetu Tirikatene-Sullivan who held the legislation up in Parliament. ${ }^{230}$ Lee was the Auckland Central MP from 1993-2001 for the Alliance Party. She affiliated to Ngāti Mamoe and Ngāi Tahu but was not involved in the Ngāi Tahu Māori Trust Board. TirikateneSullivan, also of Ngāi Tahu, was a Labour MP and held the Southern Māori seat from 19671996. Her father, Eruera Tirikatene, was the main negotiator of the 1944 settlement negotiations. Lee and Tirikatene-Sullivan were both vehemently opposed to O’Regan and the Ngāi Tahu Māori Trust Board. O’Regan attempted to appeal to Tirikatene-Sullivan

\footnotetext{
${ }^{225}$ Meeting of the Ngāi Tahu Māori Trust Board, 6 and 9 November 1992, NT 140 A39 Box 11A, MB archives. ${ }^{226}$ Ngāi Tahu Māori Trust Board to Māori Affairs Select Committee, 29 September 1993, NT140 M4 (g) Box 298, MB archives.

227 "Hui a tau o Ngāi Tahu," 5-7 November 1993, MB Archives; NZPD, 1996: 11947.

${ }^{228}$ ToWPU official 8 to CLO official 3, 26 May 1994, C-27-2-01 Vol. 2, OTS archive. Tuhuru were supported by the National Māori Congress: Charles Crofts to Api Mahuika, 11 February 1993, MB archives.

${ }^{229}$ Cabinet Memorandum Treaty of Waitangi Issues (92) 37, C-27-2-04 Vol. 2, OTS archive.

${ }^{230}$ Sandra Lee to Graham, 20 March 1992; Lee to Sid Ashton (NTMTB Secretary), 26 March 1992: NT140 Mi (u), MB archives.
} 
directly to support the legislation but she maintained her opposition for many years. ${ }^{231}$ O’Regan addressed the issue of legal personality in letters to Graham but there was little that Graham could do. Graham had introduced the legislation to Parliament but he could not force it through on his own. In March 1993 it was accorded urgency in Parliament. ${ }^{232}$ Once the Bill was introduced to Parliament, parts of the legislation came under review in the Māori Affairs Select Committee. ${ }^{233}$ Tirikatene-Sullivan and Lee were both on the Committee and they delayed the passage of the Bill. In a meeting with the Crown, Ngāi Tahu negotiators noted that Lee's role in the delaying the legislation represented a conflict of interest. The Crown emphasised that there was "no deliberate attempt...to delay passage of the Bill” but it could not guarantee that the Bill would be passed even in $1994 .^{234}$

In March 1994 Tirikatene-Sullivan and Lee were invited to a meeting with members of a Ngāi Tahu hapū, Ngāi Tuahuriri, at the Tuahiwi Marae to discuss negotiations and the legal personality legislation. Tirikatene-Sullivan and Lee expressed their disappointment at the hasty speed at which the bill was progressed. O’Regan and the Ngāi Tahu Māori Trust Board on the other were frustrated with the consistent delays. O'Regan believed that Tirikatene-Sullivan and Lee had provided some misinformation to John Crofts, a representative of Ngāi Tuahuriri, who subsequently sent a letter to ToWPU officials asking that the legislation be delayed. The following day O'Regan had a meeting with other NTMTB members and a retraction of the letter was organised. O'Regan tried to explain to members of the board that the legal personality was the platform upon which Ngāi Tahu would build its settlement and regain a measure of rangatiratanga. ${ }^{235}$ O'Regan thought that the letter to the

\footnotetext{
${ }^{231}$ O’Regan to Whetu Tirikatene-Sullivan, 1 April 1992, MB archives.

${ }^{232}$ O’Regan to Graham, 1 February 1993; Minutes of 5 March 1993 meeting between Ngāi Tahu and the Crown, C-27-2-02 Vol. 2, OTS archive.

${ }^{233}$ Minutes of 28 July 1993 meeting between Ngāi Tahu and the Crown, C-27-2-02 Vol. 2, OTS archive. ${ }^{234}$ Minutes of 26 January 1994 meeting between Ngāi Tahu and the Crown, C-27-2-02 Vol. 3, OTS archive. 235 “Ngāi Tahu Māori Trust Board In Committee Minutes,” 8-10 April 1994, NT140 M14 (c), MB archives.
} 
Crown had contributed irreparable damage to advancing the legislation through Parliament. When O’Regan corresponded with Graham in May 1994 regarding the delays in advancing the legislation, Graham stated that the situation had not been created by the Crown but by internal divisions within Ngāi Tahu. ${ }^{236}$ While in the case of the legal personality legislation it seemed that Graham was quite willing to support the bill, Ministers and officials could also use these internal divisions to justify whatever delays occurred on other issues such as the financial dimensions of the settlement.

In early 1994 an internal review of the structure of Ngāi Tahu's negotiations had emerged as a topic of discussion at Ngāi Tahu hui-a-tau. CS First Boston’s role in Ngāi Tahu's negotiations and its role with the privatisation of the Electricty Corporation of New Zealand (ECNZ), a SOE, had come under some criticism by members of the Ngāi Tahu Māori Trust Board. Garry Moore and Mark Knowles, a Christchurch accountant and solicitor respectively, were asked by Ngāi Tahu to provide advice on not only CS First Boston’s potential conflict of interest but also the structure of negotiations in general. The pressure on negotiators during an extended period of marginal progress had begun to significantly ratchet up in 1994. Legal remedies as alternatives to negotiations were increasingly being considered, especially through forestry assets in the Ngāi Tahu rohe as well as common law action regarding the acquisition of Banks Peninsula. ${ }^{237}$

Moore and Knowles’ report criticised both the Crown and specifically Graham for their role in the lack of progress but also the high cost of advisors to the Ngāi Tahu Negotiating Group. The report was meant to remain an internal document for Ngāi Tahu but it was quickly leaked to the press. Ngāi Tahu negotiators and advisors were put under

\footnotetext{
${ }^{236}$ Graham to O’Regan, 3 June 1994, C-27-4-01 Vol.3, OTS archive.

237 "Ngāi Tahu hui-a-tau," 21-22 January 1994, MB140, B(x)6 Box 53, MB archives; Davidson to Harry Evison, 31 January 1994, Vhi 15 (k), TRONT archive; Davidson to O’Regan, 9 March 1994, Vhi 15 (x), TRONT archive.
} 
considerable pressure for their alleged financial gain from the negotiating process. Graham was particularly concerned that Moore and Knowles had not been properly identified at a formal Crown-Ngāi Tahu meeting that they both attended. The incident only added to the tensions that existed between the Crown and Ngāi Tahu negotiators, and exacerbated the divisions within Ngāi Tahu. ${ }^{238}$ By November 1994 the negotiations between the Crown and Ngāi Tahu broke down, and would not resume until 1996.

The legal personality bill predictably languished in such a context despite some efforts by the Chairman of the Māori Affairs Select Committee, Labour MP Koro Wetere. ${ }^{239}$ When the Ngāi Tahu Negotiating Team decided to attempt to recommence negotiations in early 1996, they informed the Crown that the passage of the Ngāi Tahu legal personality bill was the most important aspect of the possibility of resuming negotiations. ${ }^{240}$ With the support of Prime Minister Jim Bolger, Minister of Māori Affairs Doug Kidd, and Graham on 17 April 1996 the Te Rūnanga o Ngāi Tahu Bill was given its final reading in Parliament. When Royal Assent was given on 24 April 1996 the Ngāi Tahu Māori Trust Board was dissolved and replaced with Te Rūnanga o Ngāi Tahu. ${ }^{241}$ The new organisation was now accountable to the Ngāi Tahu rūnanga and people rather than to the Crown.

\section{Conclusion}

Waikato-Tainui and Ngāi Tahu submitted their claims to the Waitangi Tribunal only months apart in 1986, but their paths to negotiation were markedly different. Ngāi Tahu participated in Waitangi Tribunal hearings for two years from 1987 to 1989 while WaikatoTainui struggled to convince the Crown to begin direct negotiations. Finally in mid-1989

\footnotetext{
${ }^{238}$ Garry Moore \& Michael Knowles, "Ngāi Tahu negotiations," 30 June 1994, C-27-2-02 Vol. 3, OTS archive; Graham to O’Regan, 10 August 1994, C-27-2-02 Vol. 3, OTS archive.

${ }^{239}$ Ashton to all Ngāi Tahu negotiators and advisors, 7 March 1995, MB archives.

240 Nick Davidson to OTS Director, 13 February 1996, TRONT archive.

${ }^{241}$ Te Runanga o Ngāi Tahu Act 1996.
} 
Waikato-Tainui’s direct negotiations with the Fourth Labour government began, although they ended in August 1990 without a settlement. Ngāi Tahu's negotiations with the Fourth National government began in September 1991, and Waikato-Tainui's negotiations with National formally commenced only two months later in November 1991. Although the grievances of each iwi were as diverse as their paths to negotiations, both Waikato-Tainui and Ngāi Tahu placed their negotiations within the desire to re-assert rangatiratanga.

In both negotiations the Crown maintained its overaching control of the process and limited both iwi's efforts at re-asserting rangatiratanga by emphasising that any negotiations regarding sovereignty were off the table. For Waikato-Tainui this meant limits on the legal form in which lands would be returned, and at first, a focus on the finality of the 1946 settlement. Ngai Tahu struggled to portray the establishment of Te Runanga o Ngāi Tahu as emblematic of the pursuit of rangatiratanga, a term which seemed to make Crown Law especially uncomfortable. The Crown also established that it would only negotiate with iwi leaders. Dissident hapū from within Ngāi Tahu and Waikato-Tainui opposed their iwi negotiators. For Ngāi Tahu the greatest level of dissent stemmed from the long struggle to establish a legal personality. Opposition from Waikato-Tainui hapū was focused on the vesting of settlement assets such as Hopuhopu and Te Rapa. From 1991-1994 both WaikatoTainui and Ngāi Tahu struggled to advance their negotiations as the Crown developed policy and settlement offers ad hoc. The political nature of Treaty settlement negotiations was evident in the limits that were placed on the wider negotiations early in the process, and the politics of negotiations was readily apparent as debates developed over the level of financial compensation that would be provided in any settlement. 


\section{Chapter 2: The Economics of Ngāi Tahu and Waikato-Tainui's Treaty settlements}

Central to the tensions that arose during the course of the negotiations for both the Waikato-Tainui and Ngāi Tahu Treaty settlements was the question of how the total value of the settlements would be ascertained and dealt with. While the Crown approached the negotiations from the perspective that earlier settlements of the 1940s only required updating, negotiators for Waikato-Tainui and Ngāi Tahu believed that the amount returned to them had to reflect the value of what they had lost. Both iwi understood that full reimbursement would have been impossible, but they believed that some rationalisation or formula was necessary. The respective negotiations established some of the basic parameters by which the Treaty settlements were intended to provide recompense for past loss, and the extent to which they were intended to facilitate improved socio-economic position for Māori, through better education and employment. The settlements that were ultimately negotiated have been estimated as less than $1 \%$ of the value of the assets that were improperly acquired from the ownership of these groups. ${ }^{242}$ Although Ngāi Tahu spent more time than Waikato-Tainui in attempting to obtain a settlement that more accurately reflected what they perceived as the financial value of their losses, the question of quantification featured as a central part of both negotiations. For both, the question was whether the amount offered by the Crown was sufficient to secure an agreement to the Crown's requirement that Treaty settlements be a full and final settlement of their historical Treaty claims. In achieving full and final settlements, the Crown's focus was not only on limiting the amount made available in these settlements, but doing so in a way that set acceptable precedents for settlements to come.

\footnotetext{
242 Damian Stone, 'Financial and Commercial Dimensions of Settlement,' in Nicola Wheen and Janine Hayward (eds.) Treaty of Waitangi Settlements (Bridget Williams Books, 2012), 145.
} 
The question of the quantification of loss for Waikato-Tainui first arose in 1989 during the Coalcorp case, when a Crown valuer estimated that the then current value of all the land in the raupatu area was approximately $\$ 6$ billion. ${ }^{243}$ By 1995 it had grown in value to around \$12 billion. Waikato-Tainui negotiators demanded that the approximate present day value of the lands confiscated by the Crown be included in the Deed of Settlement and legislation. ${ }^{244}$ From the beginning of the negotiations the Waikato-Tainui position was that they wanted all the Crown land remaining in the Waikato-Tainui raupatu area, which would form adequate compensation. But as the Crown's asset base dwindled within that area from the beginning of the negotiations in 1989 to settlement in 1994, the monetary value of Waikato-Tainui's preferred settlement diminished. For this reason, they did not attempt to advocate for a value for their settlement based on valuation studies, as Ngāi Tahu did. Ngāi Tahu's valuation studies arrived at various estimates for the value of the reserves that were never granted by the Crown during the land purchases of 1844-1864. Each estimate was in the billions. As Ngāi Tahu continued to negotiate with the Crown over the question of how their settlement should be valued in the first half of 1992, Waikato-Tainui continued to explore how to transfer as much land as possible to Waikato-Tainui within the raupatu area. The transfer of the decommissioned Hopuhopu Army Base in late 1991 and early 1992 began this process. Gradually Waikato-Tainui’s land for land principle was accommodated within the Crown's fiscal parameters.

The Crown's position during these negotiations was based on the assumption that the settlements remained a political decision because it was impossible for Treaty grievances to be fully compensated. This symbolised the dominance of the Crown's sovereignty over the rangatiratanga espoused by Waikato-Tainui and Ngāi Tahu. While these questions were

\footnotetext{
243 “Affidavit of Ross Calderwood,” Tainui Māori Trust Board v Attorney-General [1989] 2 NZLR 513 (CA). ${ }^{244}$ McCan, Whatiwhatihoe, 263.
} 
played out in the course of negotiations, it was another settlement - the fisheries settlement, signed in September 1992 - that ultimately set the benchmark for the settlements with Ngāi Tahu and Waikato-Tainui. Only two days before the fisheries settlement was signed, Cabinet set an undefined cap on the total amount of money available for all settlements. Following the signing of the fisheries settlement, the figure of $\$ 170$ million began to appear in the meeting minutes between ToWPU and Waikato-Tainui advisors as well as personal one-on-one meetings between Principal Waikato-Tainui negotiator Robert Mahuta and Justice Minister Graham. ${ }^{245}$ After the fisheries settlement, the Crown developed its policy for establishing the total sum available for all Treaty settlements, which became known as the 'fiscal envelope'. Later, after the fiscal envelope was officially dropped as Crown policy, rather than focus on the total amount available, the Crown focused on using overall financial limits to determine how Treaty settlements might be related to each other. ${ }^{246}$ Ultimately, not only did the amount set aside for the fisheries settlement become the maximum amount the Crown would set aside for both Waikato-Tainui and Ngāi Tahu, this would also become entrenched in the relativity clauses that established how these settlements would be related to future settlements with other Māori groups. These issues - the quantification of loss and the development of the fiscal envelope policy - were among the major questions addressed throughout the Waikato-Tainui and Ngāi Tahu negotiations.

Waikato-Tainui and Ngāi Tahu maintained that their settlements could not be full and final because the redress offered by the Crown represented a mere fraction of the total financial loss. Waikato-Tainui and Ngāi Tahu settlement negotiators often faced repeated questioning from their respective communities arguing the same point-settlements would have to be significantly enlarged to be considered full and final. Throughout Waikato-

\footnotetext{
${ }^{245}$ Denese Henare to Mahuta, 4 March 1993; Mahuta file note, 18 May 1993: both RC Vol 30 1993, Box 11, W$\mathrm{T}$ archives.

${ }^{246}$ The term fiscal envelope was progressively phased out and the Crown would begin to refer to the financial redress available for a settling group as the quantum policy.
} 
Tainui's negotiations the issue of finality remained prominent at all times. During these negotiations it was unclear how financially significant the settlement would be. WaikatoTainui negotiators and advisors consistently pressed on the Crown that finality was impossible under the fiscal constraints that the Crown, with Treasury advising it, had placed on the process. Ngāi Tahu was equally concerned with the durability that a limited settlement would have throughout its negotiations. At first the focus was on the limited compensation or quantum that would be provided. Later, after Waikato-Tainui's 1995 settlement which only addressed Waikato-Tainui's claims to confiscated land and not their claims to West Harbours or Waikato River, Ngāi Tahu pushed for a similar settlement that would only address their land-based grievances and thus could be confidently presented to Ngāi Tahu members. The Crown refused and Ngāi Tahu’s settlement was required to cover all of its claims.

While the Crown maintained that their settlements would have to be full and final, both Waikato-Tainui and Ngāi Tahu were able to negotiate a provision in their settlements that ensured that they would not be final for many years: the relativity clause. For every dollar that the Crown spent over the fiscal cap of \$1 billion (1994 dollars) that was allocated for Treaty settlements, Waikato-Tainui could request $17 \%$ as a top-up to their settlement. Having negotiated their settlement nearly two years after Waikato-Tainui’s settlement, Ngāi Tahu was able to negotiate a $16.1 \%$ top-up for every dollar spent over the $\$ 1$ billion threshold as the value of its settlement was marginally less as Ngāi Tahu had been paid in October 1996 dollars rather than the December 1994 dollars Waikato-Tainui received and thus the purchasing power of their $\$ 170$ million was less. In the end the relativity clause would provide a powerful rationale for Waikato-Tainui and Ngāi Tahu negotiators to press their respective members to accept the final settlements on offer. The relativity clauses would also serve as a challenge to the Crown's need for financial certainty. Although the clauses did not 
represent a distinct challenge to the Crown's sovereignty, it did affect its kawanatanga or right to govern, and enhanced Ngāi Tahu’s rangatiratanga.

Alan Ward has argued that both settlements were not necessarily viewed by the Crown as worth $\$ 170$ million, but rather as approximately $17 \%$ of the total amount available for all settlements—-the fiscal envelope. ${ }^{247}$ Certainly by the time Waikato-Tainui and Ngāi Tahu demanded relativity clauses, the Crown acquiesced to their requests to facilitate both settlements. When the Crown made a \$170 million settlement offer to Waikato-Tainui in 1994, the Cabinet paper approving the offer and the Heads of Agreement noted that the sum represented $17 \%$ of the total amount available for all settlements. In Trick or Treaty? Graham stated that the total value of Crown lands available for transfer was about $\$ 100$ million, the decommissioned Te Rapa Airbase was valued at approximately \$5 million, and \$65 million would be provided to purchase additional lands, and they only happened to add up to $\$ 170$ million. ${ }^{248}$ This was a result of the development of the Crown's Proposals for Treaty settlements from 1992-1994, but the original influence of the $\$ 170$ million figure had to have been from the fisheries settlement. Graham asked his ToWPU officials to refer specifically in their draft Cabinet paper regarding the Waikato-Tainui offer to the fact that the Fisheries settlement had set the benchmark at $\$ 170$ million. ${ }^{249}$ The Crown would retrospectively provide a rationalisation of the Waikato-Tainui settlement as $17 \%$ of the total amount available, and Waikato-Tainui gladly used that rationale to obtain the relativity clause, but the origin of the $\$ 170$ million figure was most likely from the fisheries settlement since the figures were identical.

\footnotetext{
${ }^{247}$ Ward, An Unsettled History, 54-55.

${ }^{248}$ Graham, Trick or Treaty?, 74.

249 ToWPU official 9, “File Note, Re: Meeting”, 4 October 1994, TC30 Vol. 37, OTS archive.
} 


\section{Part I: Ngāi Tahu, quantification of loss and the fiscal envelope Divergent views: Ngāi Tahu “rights” vs. Treasury "needs”}

Ngāi Tahu and the Crown began their negotiations in September 1991 with the intention of arriving at a quickly negotiated settlement. Alongside discussions about the establishment of Ngāi Tahu's legal personality, negotiations focussed on how loss would be valued and what redress could be provided. Because the Crown pressed Ngāi Tahu to make an opening proposal as negotiations got under way, Ngāi Tahu commissioned considerable research to establish the value of Ngāi Tahu's loss. The Crown did not believe that research was necessary because of the political nature of the agreement, but agreed to consider the results of Ngāi Tahu's investigations.

Although the Waitangi Tribunal report was a thorough examination of Ngāi Tahu’s claims against the Crown, there were no specific recommendations for settling Ngāi Tahu’s economic loss. At the commencement of the hearings both the claimants and the Crown had asked the Tribunal to make findings on the issues and determine whether there had been breaches of any Treaty principles, but to defer the question of remedies to allow for a negotiated settlement. During the Tribunal hearings Ngāi Tahu argued that the Crown had promised to reserve for Ngāi Tahu a tenth of the land that was sold. The Tribunal was unable to locate specific evidence of Crown promises made to that effect, but it nonetheless found that the Crown had breached Treaty principles by providing insufficient reserves to Ngāi Tahu-approximately 24,500 acres out of a total of approximately 34 million acres. While the Tribunal did not specifically find that a tenth of the total land area sold by Ngāi Tahu should have been reserved for them, it did note that had 3.4 million acres ${ }^{250}$ been reserved for

\footnotetext{
${ }^{250}$ One tenth of the approximately 34 million acres sold between 1844 and 1864 .
} 
Ngāi Tahu it "would have been greatly to their advantage." ${ }^{251}$ It was upon these findings that Ngāi Tahu based their negotiating principles. At the centre of Ngāi Tahu’s negotiating principles was establishing the value of their loss as the current value of one tenth of the land that Ngāi Tahu sold between 1844 and 1864. The main point of contention was the question of whether the Crown had been obligated to provide a tenth of the land sold for Ngāi Tahu's use. Internally Ngāi Tahu negotiators had calculated the value of 3.4 million acres at approximately $\$ 1.3$ billion. ${ }^{252}$ This figure was too high for the Crown and even what Ngāi Tahu perceived to be a significant compromise was rejected because the amount of compensation was still far too large. The Crown had opposed Ngāi Tahu's arguments on “tenths” during the Tribunal hearings and they continued to oppose Ngai Tahu's arguments during the negotiations.

Ngāi Tahu's case during the negotiations focused on the loss of property rights. They sought compensation for a number of grievances. The largest grievance, economically, related to the difference between the reserves that were awarded from 1844-1864 (approximately 24,500 acres) and the reserves that Ngāi Tahu argued should have been awarded (approximately 3.4 million acres). Ngāi Tahu also pointed to the significant gap between Ngāi Tahu’s expectations for payment at the time and the marginal amounts paid by the Crown, redress for insufficient health and educational endowments, and restricted access

\footnotetext{
${ }^{251}$ Waitangi Tribunal, The Ngāi Tahu Report, (Wellington: Waitangi Tribunal, 1991), 828-829. “Given that Ngāi Tahu undoubtedly owned the land, the vesting in them of an area which amounted to about 1133 acres per person, particularly when compared with the much more extensive runs thought appropriate to the needs of European settlers, could scarcely be regarded as generous. The tribunal cites this merely by way of example and not because we see it as the appropriate measure of the land which should have been left with Ngāi Tahu. Ngāi Tahu clearly had a need of land which would have been suitable for pastoral or other forms of farming. But Ngāi Tahu also had a strong affinity, in some cases of a spiritual nature, to other notable features of the landscape. Prominent is Aoraki (Mount Cook). Their trails throughout their extensive domain, including those over the great mountain range, their lakes and rivers, were all taonga, all greatly prized. Instead, these people, the tangata whenua, whose homeland it was, were against their will reduced to subsist on a mere 12 acres per person. Their rangātiratanga denied; their future both tribally and individually bleak; their Treaty rights ignored. All this with the knowledge or connivance of successive governors acting on behalf of the Crown.”

2521991 dollars.
} 
to mahinga kai. ${ }^{253}$ Ngāi Tahu strove to establish a baseline for the value of its historical loss but this was difficult to do. Malcolm Hanna, a valuation consultant, was engaged by Ngāi Tahu to produce an assessment. His preliminary report found the total unimproved value current at that time of the eight land blocks was $\$ 13$ billion in 1990 terms. Hanna produced a report on the principles and procedures for the assessment of compensation for land claims. He did not think the Crown would follow along with the idea of tenths. The largest sum could be obtained by using the Public Works Act to provide compensation for land not provided as reserves. Since the Public Works Act applied to land that was taken by the Crown, Hanna recommended using the difference between reserves actually awarded by the Crown and the reserves Ngāi Tahu believed they should have been awarded to calucuate the compensation. Hanna acknowledged that the Crown would not be likely to agree to that calculation. ${ }^{254}$

Although the negotiations overall were primarily conducted through ToWPU officials, discussions over the quantification of Ngāi Tahu's loss were managed primarily through Treasury officials. Treasury's role was to limit the fiscal impacts of Treaty settlements on the financial state of the government as a whole. Treasury concentrated on restoring the capacity of Ngāi Tahu on a “needs” basis: Treasury sought to determine how much compensation would be necessary to take Ngāi Tahu collectively out of poverty. ${ }^{255}$ Treasury refused to recognise what Ngāi Tahu perceived to be an economically conservative view on property rights. Initially Graham approved of some level of quantification, what was referred to during meetings and correspondence as the "peg in the ground" but he continually

\footnotetext{
${ }^{253}$ O’Regan to Ashton, 16 October 1991, Vhi 10 (a) Box 149, TRONT archive; 1-2; Davidson, "Establishing Principles for the Negotiations on Reserves Not Awarded,” 14 October 1991, Vhi 10 (a) Box 149, TRONT archive; Malcolm Hanna, "Report to the Ngāi Tahu negotiating team concerning principles \& procedures for the assessment of compensation for land claims, December 1991,” Vhi 14 (e) Box 150, TRONT archive; Commissioner of Crown Lands, "Reserves Not Awarded working party,” C-27-3-01 Vol. 1, OTS archive. ${ }^{254}$ Malcolm Hanna, "Public Works Act,” 18 December 1991, Vhi 14 (e) Box 150, TRONT archive.

${ }^{255}$ Nick Davidson, "Establishing Principles for the Negotiations on Reserves Not Awarded,” 14 October 1991, Vhi 10 (a) Box 149, TRONT archive.
} 
stressed that Cabinet would be looking for a political decision on the total claim rather than examining and quantifying each grievance.

Treasury's focus on needs inevitably shifted the historical focus away from tenths and on to calculations of what "needs" might actually represent in reality. Treasury was interested in developing a demographic and socio-economic picture of the composition of Ngāi Tahu tribal members. O’Regan forwarded to Treasury two limited studies which he noted were investigated "before the worst effects of restructuring were visited on our people." "Recent policy has substantially increased unemployment and disadvantage in housing, further education and health. As yet we have not fully documented these effects. We are still reeling from their impact.”256 The neo-liberal economic reforms of the mid to late 1980s undertaken by the Fourth Labour government continued under the Fourth National government in the 1990s. The reforms increased Māori unemployment, and affected Māori involvement in both the economic and political spheres. As Cybele Locke has noted the neo-liberal reforms were felt more harshly by Māori (and Pacific Islanders) than by Pākehā New Zealanders. In 1992 Māori unemployment was at 25.8\% while the Pākehā unemployment rate was $8.1 \% .{ }^{257}$ O’Regan thus took the chance to show Treasury the historical continuity of dispossession that bound the current Ngāi Tahu generation to the grievances of the past.

All of this correspondence regarding the composition of Ngāi Tahu occurred despite Ngāi Tahu's insistence on using a rights-based approach rather than a needs-based approach. As O’Regan stated in correspondence with Treasury officials, "We could see the 'Needs' argument coming some three years ago.” Commentators such as Michael Belgrave have made similar retrospective observations about the Crown's focus on “needs” rather than property rights. Belgrave has commented on the manner in which Treasury "emphasised the

\footnotetext{
${ }^{256}$ O’Regan to Treasury official 7, 23 December 1991, C-27-3-01, OTS archive, 2.

${ }^{257}$ Cybele Locke, Workers in the Margins: Union Radicals in Post-War New Zealand (Wellington: Bridget Williams Books, 2012), 13.
} 
re-establishment of the tribal estate as the primary focus of settlements” and suggested that “redress could be achieved relatively inexpensively." 258 O’Regan had to engage in discussions with Treasury to convince them that Ngāi Tahu had a large population. Under the needs based model proposed by Treasury, the more Ngāi Tahu people there were the greater the compensation would be. In a bid to avoid fighting an unwinnable war with the Treasury over what Ngāi Tahu needs were O'Regan recommended hiring a mutually acceptable person to define Ngāi Tahu's social needs. ${ }^{259}$

As Treasury and Ngāi Tahu engaged in negotiations regarding financial redress, discussions continued over the quantification of Ngāi Tahu's loss within ToWPU. ${ }^{260}$ ToWPU officials conceded that the estimation of the dimensions of the 'redress envelope' would be difficult. There was no clear-cut methodology for determining what would be appropriate. ${ }^{261}$ A ToWPU official attempted to bridge the gap between the Treasury and Ngāi Tahu positions by emphasising the need for restoration, pressing specifically in a memorandum to draw the Cabinet's attention to the instructions from Lord Normanby to Hobson in 1839. Normanby had explicitly instructed Hobson to not enter into any contracts with Māori that would be injurious to them. The ToWPU official sought to restore Ngāi Tahu to the position it may have been in had Treaty breaches not occurred by "re-affirming it with an economic base and thus enhancing its rangatiratanga." 262

\footnotetext{
${ }^{258}$ Belgrave, Historical Frictions, 320, 325-326.

${ }^{259}$ O’Regan to Treasury official 7, 27 December 1991, C-27-3-01 Vol. 1, OTS archive, 3; O’Regan to Treasury official 7, 30 December 1991, Vhi 10 (d) Box 149, TRONT archive.

260 "Framework Agreement between Crown and Ngāi Tahu negotiators," 27 November 1991, C27/2/02 Vol 1.

261 (Graph) "Sequencing Work Required to Settle Ngāi Tahu Claim," 4 November 1991, C27/2/02 Vol 1., 2-3; Dangerfield to O’Regan, 20 \& 24 December 1991, C-27-3-01 Vol. 1, OTS archive; O’Regan to Treasury official 7, 27 December 1991, C-27-4-01 Vol. 1, OTS archive;

${ }^{262}$ Memorandum for Cabinet, "Proposed Objectives and Approaches to Redress for the Ngāi Tahu Negotiations,” 13 September 1991, C27-2-02 Vol. 1, OTS archive, 2-3; Lord Normanby to Captain Hobson, 14 August 1839, Great Britain Parliamentary Papers 1840 in Vincent O’Malley, Bruce Stirling and Wally Penetito (eds.), The Treaty of Waitangi Companion: Māori and Pākehā from Tasman to Today (Auckland: Auckland University Press, 2010), 35-36; Orange, Treaty of Waitangi, 29-31.
} 
A Treasury official had some substantial criticisms of the principles proposed by ToWPU, specifically those which would try to restore Ngāi Tahu to a position that it would have been in had the Crown not breached the Treaty:

[I]t would imply the Crown aims to provide redress to a value equivalent to the estimated total loss incurred by Ngāi Tahu; the Crown has no accurate idea of the size of that loss or, indeed, whether it can be estimated on anything other than a highly subjective basis (historical research as objective undermined) but the order of magnitude is likely to be very large relative to the Crown's ability to pay; the risk, therefore, is that the Crown would be committing itself to achieve an unobtainable objective. ${ }^{263}$ [parantheses are from the original memorandum]

Despite Treasury’s comments, Ngāi Tahu had accepted from the beginning that it did not expect full compensation but merely an agreement between themselves and the Crown on what the extent of their loss had been. Only when the extent of the loss had been established would it be possible to begin justifying whatever gap existed between the value of Ngāi Tahu's total loss and the compensation that would be provided. By dismissing Ngāi Tahu's dollar estimation of its own loss (which was in the billions) as simply the basis for "highly subjective...historical research” Treasury attempted to cast doubt on the severity as well as the veracity of Ngāi Tahu's loss. A value framework to govern how much was going to be necessary for a settlement would remain important to the overall trajectory of the negotiation. $^{264}$

O’Regan commented to other Ngāi Tahu negotiators and advisors: “We are establishing a Rights base and the Crown is trying to establish a Needs base. We're avoiding population arguments and relying very much on the 'present and future needs of Ngāi Tahu' line that the Tribunal developed. At the moment we don't think they can escape ' 10 ths across the board"." While the use of the term "present and future needs of Ngāi Tahu” sounded like a needs based approach, Ngāi Tahu were still focused on their rights approach. Unfortunately

\footnotetext{
${ }^{263}$ Treasury official 6, "Principles for Ngāi Tahu Negotiations,” November 1991, C27/2/02 Vol 1, 1-2. ${ }^{264}$ Interview with ToWPU official 1, 27 July 2011.
} 
for Ngāi Tahu the Crown refused to accept the notions of tenths because it would make the Crown liable for sums which it could not afford although it arrived at somewhat similar calculations for the value of Ngāi Tahu's loss. ${ }^{265}$ It was within the context of these "rights" versus "needs" debates that Ngāi Tahu made its first formal settlement proposal to the Crown.

\section{Ngāi Tahu's February 1992 Settlement proposals}

Early in 1992 Graham asked that Ngāi Tahu provide a written proposal to the Crown which detailed Ngāi Tahu’s preferences for settlement. Ngāi Tahu’s commercial consultant, Stephen Jennings, addressed in an internal memorandum the different ways that a Ngāi Tahu proposal for compensation could be presented to the Crown. Jennings wrote:

We all agree that we need to vigorously resist Treasury's approach. At the same time, however, we must recognise that Treasury's advice to the Minister of Finance will have a major bearing on the Crown's final position regarding the reserves not awarded component of the settlement. It is important, therefore, that we monitor Treasury's needs-based work and try (behind the scenes) to influence the direction of that work. We should also provide Treasury with data they require where this will assist our ultimate end (e.g. data which increases the measured size of Ngāi Tahu).

Jennings was essentially advocating the control of the flow of information on which Treasury might base its calculations of what Ngāi Tahu's needs were. This would have included demographic data that detailed the population and incomes of Ngāi Tahu members. Jennings was a Treasury official during the 1980s and may have believed that he could personally persuade Treasury officials. Furthermore Jennings stressed that Treasury's needs based approach could result in a larger settlement than a rights based approach if the benchmarks were tied to mean or median community income levels. A settlement of " $\$ 1.5$ billion would be required to provide an annual per capita gain of $\$ 1,500$ to $60,000 \mathrm{NT}$, assuming a 6

\footnotetext{
${ }^{265}$ O’Regan to Ashton, 16 October 1991, Vhi 10 (a) Box 149, TRONT archive; 1-2; Davidson, “Establishing Principles for the Negotiations on Reserves Not Awarded,” 14 October 1991, Vhi 10 (a) Box 149, TRONT archive; Hanna, "Report to the Ngāi Tahu negotiating team concerning principles \& procedures for the assessment of compensation for land claims, December 1991,” Vhi 14 (e) Box 150, TRONT archive; Commissioner of Crown Lands, "Reserves Not Awarded working party,” C-27-3-01 Vol. 1, OTS archive.
} 
percent after tax return on the total asset base received.” Jennings also noted that Treasury's attitude towards a settlement would also be influenced by their perception of Ngāi Tahu's financial accountability. The question was where to begin the bidding? $\$ 1.3$ billion was the most conservative estimate established by Ngāi Tahu’s valuation studies and Jennings recommended that figure as the opening bid. ${ }^{266}$

Ngāi Tahu and the Crown held a formal negotiation session three days before Ngāi Tahu delivered its proposals for settlement to the Crown. Both sides remained in disagreement regarding the basis for establishing financial redress. Ngāi Tahu felt that "a needs-based solution would be more expensive to the Crown than a rights-based solution.” Although the Crown was generally uncomfortable with the question of a valuation of Ngāi Tahu's loss, at this meeting Graham "felt agreement was required as to what Ngāi Tahu have lost and advised that a prima facie position was probably all that was needed.” ${ }^{267}$ These statements reflected the continuing stress that Ngāi Tahu placed on its rights-based solution, and the Crown's continuing hesitancy with estimating the value of the lands Ngāi Tahu had not been awarded during the mid-1800s.

Ngāi Tahu made its proposal for the total value of their settlement in a letter from O’Regan to Graham on 7 February 1992. Ngāi Tahu sought \$1.3 billion as compensation for all of their claims. Ngāi Tahu stated that their approach to settlement was based upon principles which emerged from Tribunal report that the "Crown acted unconscionably and in repeated breach of the Treaty of Waitangi...The tribe is clearly entitled to a very substantial redress from the Crown...The Crown's obligation to effect redress in this case is indeed a heavy one.” O’Regan also noted that the remaining lands in the Crown's possession would not provide Ngāi Tahu with an economic base, even if the transfer of all Crown land was a

\footnotetext{
${ }^{266}$ Stephen Jennings to Ngāi Tahu Negotiators, 3 February 1992, VH i 10 (g) Box 149, TRONT archive, 3. 267 "Meeting between Crown and Ngāi Tahu negotiators," 4 February 1992, C-27-8-01 Vol. 1, OTS archive, 5 , 7.
} 
possibility. While the Crown and Ngāi Tahu were conducting the negotiations through different principles, Ngāi Tahu tried to stress that there also existed some commonalities. ${ }^{268}$ O’Regan couched his statement in the language of needs-based solutions that Treasury advocated, claiming that to achieve a final and durable settlement the "size and composition of the assets package will need to be such that the overriding objective of restoring Ngāi Tahu economic health and self-sufficiency is achieved.” O’Regan stated that a "very conservative valuation approach, based on current land values within Ngāi Tahu's rohe" was approximately $\$ 1.3$ billion. O’Regan believed that the capital value of the reserves that were not awarded was far in excess of that figure, which is the value of both the land and all the improvements on the land such as buildings, farm stock or crops. O’Regan conceded that compensation of that magnitude would not be possible so he requested just the land value of the reserves that were not awarded--\$1.3 billion. Ngāi Tahu envisioned having a diverse range of Crown assets such as forestry cutting rights and land, commercial property owned by the Crown, properties already in their land-bank, Landcorp land, SOE shares, Housing Corporation properties and mortgages, indigenous forests, coal mining licences, Crown pastoral leases and any remaining compensation as cash to make up their proposed $\$ 1.3$ billion settlement. Ngāi Tahu were also interested in obtaining shares in State-Owned Enterprises if they were privatised in the future such as The Power Company Limited, Trans Power NZ and Electricity Corporation of New Zealand (ECNZ). The land owned by these State-Owned Enterprises was covered by the 1988 Treaty of Waitangi (State Enterprises) Act, but if the entire business was privatised or even partially privatised as Mighty River Power was in 2012 Ngāi Tahu was interested in purchasing shares. O’Regan stressed that

\footnotetext{
${ }^{268}$ O’Regan to Graham, 7 February 1992, C-27-3-01 Vol. 1, OTS archive, 2.
} 
Ngāi Tahu were willing to discuss any payment deferral mechanisms to accommodate the Crown's fiscal limitations. ${ }^{269}$

The Crown disagreed with the entire Ngāi Tahu proposal. An internal Crown memorandum signed by the Justice Secretary, but presumably with heavy Treasury input, set out the Crown position with regard to Ngāi Tahu's valuation of its loss. The Secretary stated that Ngāi Tahu's calculations had "some serious limitations in terms of providing a practical basis for a settlement.” ${ }^{270}$ The Crown argued that there was "no objective way of establishing the extent to which the estimated current value of the reserves not awarded would have been similar if the land had been retained by Ngāi Tahu, instead of being developed by others.” Although estimating the value of the reserves that were not awarded was a difficult task, there could have been an effort made by the Crown to average out the value of land and identify the value of land around which substantial Ngāi Tahu kainga and mahinga kai sites existed. While the estimated current market value of those lands would have been difficult to calculate, there could have been a lower baseline value established to determine the least that the lands could have been worth without any development whatsoever such as farming or housing subdivisions. The Secretary alluded to the benefits that individual Ngāi Tahu had received from the loss of their land: "some of the betterment of the original land that should have been reserved for the tribe, has been distributed indirectly to the tribe as a member of the various local communities which have benefited from the development of former Ngāi Tahu land.” Finally the Justice Secretary claimed that Ngāi Tahu's valuation of their loss "takes no account of the value of any government assistance provided over the years specifically to assist Ngāi Tahu or Māori people.” He stated that it was not fiscally possible to

\footnotetext{
269 "Meeting between Crown and Ngāi Tahu negotiators," 29 April 1992, C-27-2-02 Vol. 2, OTS archive, ${ }^{270}$ Secretary of Justice, "Ngāi Tahu”, 11 February 1992, C-27-3-01 Vol. 1, OTS archive.
} 
provide Ngāi Tahu with assets totalling \$1.3 billion. ${ }^{271}$ Ngāi Tahu’s focus on the valuation of their loss was understandable from their point of view. Ngāi Tahu whanau and marae had demanded a rationalisation from the Crown regarding their settlement. The Crown for its part had to be realistic about what could be provided in terms of both the immediate financial consequences for the Crown's own balance sheets, and the precedent effect that such a large settlement could have on settlements with all of the other iwi. A compromise between the two positions was necessary.

Only days after receiving Ngāi Tahu’s proposal, the two sides met for a formal negotiation session. Graham stated that the Crown could not provide \$1.3 billion as a settlement. The Crown proposed \$100 million. Ngāi Tahu rejected the Crown’s \$100 million offer. Graham pressed that there was no precedent for these types of negotiations and the Tribunal's report regarding an economic base had been rather vague. Graham stated that "Ngāi Tahu have been deprived of opportunity and this now has to be corrected. To quantify this is extremely difficult.” The Crown stated that a settlement would have to be reached which the Crown, Ngāi Tahu and the people of New Zealand believed was fair. The Crown acknowledged that some compensation was necessary but as one of its negotiating principles it stressed that any settlement would have to take into account the practical and economic impact the settlement would have on the country as a whole.

The Crown wishes to negotiate a figure which it believes is fair and will allow Ngāi Tahu the opportunity to develop in a productive stage and out of grievance mode. Ngāi Tahu has put forward a figure of $\$ 1.3$ billion, which is said to be an understatement of the loss, but is beyond the Government's ability to pay. Combined wisdom is required to reach a figure which may be based on nothing more than an inside feeling that it is fair...There is concern as to what the Crown can do to restore its own honour and enhance Ngāi Tahu's mana so it has a base on which to build.

The Crown's response was certainly reasonable. Ngāi Tahu responded that they were haunted by previous governments that had refused to deal with the Ngāi Tahu claim. Ngāi Tahu also

\footnotetext{
${ }^{271}$ Secretary of Justice, "Ngāi Tahu”, 11 February 1992, C-27-3-01 Vol. 1, OTS archive.
} 
noted that they were concerned that the guilty party, the Crown, was acting in the role of the judge, a sentiment which would re-occur throughout the negotiations. Ngāi Tahu was concerned about the durability of what they perceived to be the Crown's financially limited settlement offer. Their fiscally limited settlement in 1944 was also meant to be durable, but it was inadequate even before it devalued with inflation. As a result Ngāi Tahu remained cautious about the size of the quantum offered by the Crown. ${ }^{272}$

In a letter to Graham the day after the meeting O’Regan stated that the Crown's proposal for a package valued at \$100 million was substantially below Ngāi Tahu's "most reasonable expectations.” O’Regan continued: “We continue to believe that achieving the durability sought both by Ngāi Tahu and the Crown will depend on the adoption of a principled approach, based on the findings of Waitangi Tribunal on 'Reserves not Awarded' and linked to a mutually accepted valuation of Ngāi Tahu's loss.” In light of the significant gap between Ngāi Tahu and the Crown on the issue of settlement quantum Ngāi Tahu proposed to devote considerable effort to find a level that would suit both parties, but warned that Ngāi Tahu still intended "to review that identification against Ngāi Tahu's losses before making a formal response to your proposal.”273

According to Ngāi Tahu legal advisor Nick Davidson, a Department of Conservation (DoC) official informed him that the $\$ 100$ million offer by the Crown originated solely from Treasury.

[The official] then went on to make a comment about the considerable distance between the Crown and Ngāi Tahu on the initial numbers. He seemed to indicate that we were about \$350 million apart. He said that the Crown's initial offer of \$100

\footnotetext{
272 "Meeting of Ngāi Tahu and Crown negotiators," 11 February 1992, C-27-2-03 Vol.1, OTS archive, 2.

${ }^{273}$ O’Regan to Graham, 12 February 1992, C-27-3-01 Vol. 1, OTS archive, 1-2; Ngāi Tahu legal advisor Nick Davidson stayed with Graham and a few other Crown officials following the meeting for some drinks and was able to have some candid conversations regarding the recent proposal for settlement that Ngāi Tahu had sent the Crown. "There was no specific mention of the letter we tabled on Friday other than one brief comment from the Minister not directed at me specifically but to the effect that perhaps we had got the decimal point in the wrong place. I apologised for the fact that laser printers sometimes throw fullstops too far to the left."
} 
million had not been at all well-handled. According to him the number had been dreamt up by Treasury. I had always tended to the view that it was a Doug Graham number. ${ }^{274}$

A Treasury official had been asked during a Cabinet committee meeting how Treasury had arrived at the $\$ 100$ million figure. The Treasury official refused to provide an explanation. Finance Minister Ruth Richardson then allegedly became frustrated at the increased level of scrutiny. "It was [in the DoC official's] view that the episode in the Cabinet committee had been quite damaging to the Crown's internal processes. He put the blame at Treasury's doorstep.”275 Davidson later stated that Graham was also critical of Treasury. Davidson commented to the Ngāi Tahu negotiating team in a memorandum:

I felt that the tone of [Graham's] reference to [Treasury officials] was less than glowing. He then went into a diatribe about hordes of people carrying out complicated calculations and statistical analyses in order to reach doubtful conclusions about how much money it would take to restore the wellbeing of any individual. He thought that these sorts of exercises tended to do nothing but produce a figure which was in capital terms so excessive that it was irrelevant. At the end of the day, he said, it came down to the art of the political possible. ${ }^{276}$

After the Crown's rejection of Ngāi Tahu's \$1.3 billion proposal, O’Regan wrote to Graham again on 27 February 1992 to make another proposal which would take into account the economic and fiscal constraints of the government. O’Regan again stressed that to ensure finality and durability a substantial sum had to be provided. ${ }^{277}$ Ngāi Tahu's new proposal consisted of halving the amount of their $\$ 1.3$ billion proposal to approximately $\$ 650$ million in the same diverse set of assets proposed in their first proposals. O’Regan struggled to understand why Ngāi Tahu was forced to bear the burden of New Zealand's "unsatisfactory economic performance over the last 20 years” after the Crown had accepted most of Ngāi Tahu's grievances. O’Regan alluded to the difficulties of negotiating a Treaty settlement in a time of economic uncertainty. Since the early 1970s New Zealand's economy had

\footnotetext{
${ }^{274}$ Nick Davidson, “Meeting with DoC official,” 26 June 1992, Vh 10 gg Box 149, TRONT archive.

${ }^{275}$ Nick Davidson, “Memo,” 26 June 1992, Vhi 10 (gg) Box 149, TRONT archive.

${ }^{276}$ Nick Davidson, "Note of a meeting at Vogel House," 9 February 1992, Vh 12 c Box 150, TRONT archive, 5.

${ }^{277}$ O’Regan to Graham, 27 February 1992, C-27-3-01 Vol. 1, OTS archive, 1-3.
} 
struggled. ${ }^{278}$ O’Regan believed that the Crown was forcing Ngāi Tahu to share “a disproportionate burden of these economic costs” in addition to the suffering experienced by individual Ngāi Tahu from economic restructuring during the 1980s and 1990s under neoliberal economic reforms. If Ngāi Tahu was being forced to bear the costs of New Zealand's economic situation, O’Regan also wanted Ngāi Tahu to gain from any improvement in New Zealand's future economic performance. O’Regan proposed that the sum that Ngāi Tahu were paid yearly by the Crown would depend on New Zealand's Gross Domestic Product (GDP) growth relative to the mean Organisation of Economic Cooperation and Development (OECD) GDP growth. "Specifically, we propose that no payment be made if New Zealand's GDP growth in any given year is less than 40 percent of the mean OECD GDP growth rate and that \$50 million be paid if NZ's GDP growth exceeds the mean OECD growth rate.” Ngāi Tahu stated that their new offer entailed major concessions on behalf of Ngāi Tahu while recognising the Crown's economic constraints, but that it could still prove final and durable. ${ }^{279}$ One of the most frustrating aspects of the rejection of the Ngāi Tahu settlement proposals from Ngāi Tahu's perspective was that the Crown refused to provide its response in writing. Ngāi Tahu negotiators never received an answer to their first or second February 1992 proposals. $^{280}$

For a few months from the end of February to June 1992 Ngāi Tahu and Crown negotiators argued over the reliability of Ngāi Tahu's estimates of its historical loss. A valuation exercise was established with Ngāi Tahu and a Crown appointed valuer from Valuation New Zealand (VNZ) to investigate the value of the reserves that were not awarded to Ngāi Tahu. ${ }^{281}$ The exercise was marked by ongoing disagreements between the Ngāi Tahu

\footnotetext{
278 James Belich, Paradise Reforged: A History of the New Zealanders from the 1880s to the Year 2000, 394413; Cybele Locke, Workers in the Margins: Union Radicals in Post-War New Zealand, 12-13.

${ }^{279}$ O’Regan to Graham, 27 February 1992, C-27-3-01 Vol. 1, OTS archive, 1-3.

${ }^{280}$ Interview with Sir Tipene O’Regan, 5 May 2011.

${ }^{281}$ Treasury official 6 to Treasury official 7, 17 February 1992, C-27-3-01 Vol. 2, OTS archive.
} 
and VNZ valuation experts on the relative reliability of sources of information and the methodology used for arriving at an estimate. ${ }^{282}$ For the Ngāi Tahu valuation expert some of the key components focused on trying to establish land values at the time of purchase, the influence of wool prices and the presence of gold mining. ${ }^{283}$ The VNZ expert sought to minimise the number of contextual factors the investigation considered and downplayed the low prices that were paid by the Crown for Ngāi Tahu land. ${ }^{284}$ The Crown generally ignored the results of the investigation which arrived at a value of Ngāi Tahu loss set in the billions. It remained difficult for the parties to advance the negotiations with a valuation exercise since the settlement offer would remain a political decision made almost solely by the Crown. ${ }^{285}$

In June 1992 ToWPU attempted to put together an offer that doubled the \$100 million settlement developed by Treasury. Treasury, however, offered little support. ToWPU and TPK both agreed with a paper commissioned by ToWPU and written by an external economist, Brian Easton, which found that the new offer would help Ngāi Tahu solidify an economic base. The paper by Easton argued that any economic liabilities would be counteracted by the increase in investment that it would provide for the region, and thus more jobs for the South Island. Treasury argued that despite the views of ToWPU, TPK and Easton, the new package would not represent “a durable or equitable” settlement. It began by noting that in the past settlements had not proved full and final but neglected to note that this may have been because of the lack of Crown willingness to provide any substantial compensation and in the case of Ngāi Tahu's 1944 settlement, been largely perceived to have

\footnotetext{
${ }^{282}$ VNZ official 1 to Treasury Secretary and Treasury official 6, 17 February 1992, C-27-3-01 Vol. 2, OTS archive.

${ }^{283}$ VNZ official 2 to Stephen Jennings, 3 and 9 March 1992, Vhi 14, TRONT archive.

${ }^{284}$ Valuation report to Ngāi Tahu negotiators, 28 April 1992, Vhi 14, TRONT archive.

${ }^{285}$ Graham to O’Regan, 28 April 1992; O’Regan to Graham, 29 April 1992: both C-27-4-01 Vol. 2, OTS archive.
} 
been imposed. ${ }^{286}$ Treasury questioned how Ngāi Tahu was going to distribute their compensation, what the socio-economic status of the community was relative to the rest of the Māori population, and questioned why the assets which Ngāi Tahu were set to receive in the fisheries settlement were not included in the assessment. In the cover letter to Graham, ToWPU officials noted that Treasury emphasised that their separate views be particularly noted in the report but ToWPU expressed some frustration at Treasury’s observations stating that it was far from clear how the fisheries settlement would be distributed (it had not yet been finalised) and that Ngāi Tahu's fisheries claims were completely separate from these land-based claims. ToWPU officials were frustrated with Treasury’s intransigence remarking, “it seems to us that on a preliminary view Treasury's arguments re durability mean in the final analysis that in their eyes a settlement is impossible.” The Cabinet Strategy Committee took Treasury’s advice and rejected the \$200 million proposal advocated by Easton, ToWPU and TPK. ${ }^{287}$

The two parties were too far apart on the issue of compensation. As the discussions over the quantification of Ngāi Tahu's loss dragged on through 1992 they were disrupted by the Fisheries Settlement and the subsequent gradual development of the fiscal envelope policy from 1992 to 1994. On 21 September 1992, Cabinet agreed to the establishment of a "Settlement Fund.” ${ }^{288}$ The pan-Māori fisheries settlement, often referred to as the "Sealord Deal,” was signed two days later on 23 September 1992. Coupled with the interim \$20 million fisheries settlement of 1989, the settlement was worth a total of $\$ 170$ million. Clause 4.6 of the fisheries Deed of Settlement stated that the settlement amount of \$170 million

\footnotetext{
${ }^{286}$ Ngāi Tahu's argument was not accepted by the Crown, which cited the support of Southern Māori MP Eruera Tirikatene and a number of Ngāi Tahu marae in 1944.

${ }^{287}$ ToWPU official 3 and ToWPU official 6 to Graham, 16 June 1992; CSC (92) 89; Minister of Justice to Chairperson Cabinet Strategy Committee, "Ngāi Tahu Negotiations, 12 June 1992, all: C-27-1-02 Vol. 2, OTS archive.

${ }^{288}$ CAB (92) M38/11, para C viii, C-27-1-02 Vol. 2, OTS archive.
} 
would be deducted from a Treaty of Waitangi Settlement Fund. In essence the fisheries settlement was to be deducted from a settlement fund, the amount of which had not yet been decided (and indeed was not decided until December 1994). ${ }^{289}$ The $\$ 170$ million figure would become the upper limit benchmark for Treaty settlements.

\section{Ngāi Tahu and the Crown's internal development of the fiscal envelope: 1992-1994}

The idea of an overall fiscal limit for all settlements had always been a significant issue for the Crown to consider because of the financial impact that Treaty settlements could have on the country as a whole. The fiscal limit was first formally referred to in the “Settlement Fund” Cabinet paper that was produced two days before fisheries settlement. Graham introduced Ngāi Tahu to the fiscal envelope concept at an intense weekend negotiating session held in Wellington in early August 1992 to break the dead-lock that had developed over the quantification issues. The Crown informed Ngāi Tahu negotiators of its policy to impose a fiscal limit on all Treaty settlements. There was a lack of support for such an arrangement from Ngāi Tahu negotiators. ${ }^{290}$

Following the fisheries settlement in 1992, the Crown embarked on a two-year internal development of a Treaty settlement policy with the involvement of officials from Departments across the public sector, led by ToWPU, Treasury, TPK, DoC and the Crown Law Office (CLO). ${ }^{291}$ Nearly a year after sending their first proposal to the Crown, O’Regan wrote to Graham in early February 1993 expressing Ngāi Tahu’s disappointment with the pace of negotiations and the lack of agreement. O’Regan essentially offered the same proposal that Ngāi Tahu had sent at the end of February 1992. O’Regan expressed Ngāi

\footnotetext{
${ }^{289}$ Fisheries Deed of Settlement, 23 September 1992, Clause 4.6

${ }^{290}$ CLO official 2 to Treasury, 16 July 1992, C-27-4-01 Vol. 2, OTS archive; "Hotel de Vin meetings," 4 August 1992, NT140, F(i)3; Interview with ToWPU official 3, 18 April 2011.

291 A Ph.D thesis by a historian and former OTS official regarding the development of Treaty settlement policy at a national level will explore some of this development in some detail when it is completed in the next couple of years.
} 
Tahu's objection to the envelope approach which the Crown was developing to settle Treaty claims. Graham began the negotiations by stating that he did not want to engage in a sort of “Dutch auction.” O’Regan accused Graham and Crown officials of creating a negotiation process that was far worse; O’Regan termed it a “lolly scramble.” In O’Regan’s view the Crown was forcing Māori into conflict with each other by pitting iwi against iwi for the limited financial compensation that was available overall. He also accused the Crown of taking on the same colonial positions that government officials Walter Mantell and James Mackay had taken to create Ngāi Tahu's grievances in the nineteenth century. ${ }^{292}$ While there was only a measured response to O’Regan's letter from Graham, internally Crown officials were frustrated at Ngāi Tahu's allegations of colonial attitudes. ${ }^{293}$ Some officials were working very hard to persuade Ministers to be more generous and some were not as helpful, but both groups bore the brunt of Ngāi Tahu's frustrations. In comments to the New Zealand Herald, O'Regan stated that he did not believe that Graham had developed the fiscal envelope policy as a divide and conquer tactic but that a distinction had to be made between the "honourable motives of one individual Cabinet minister and the behaviour of the State machine.” Former Minister of Māori Affairs and fisheries co-negotiator Matiu Rata did not think that limits on compensation would ensure finality. Rata pointed out that "the package [fiscal envelope policy] idea was referred to in the settlement deed of the Sealord fisheries claim, but the Government had not discussed it with Māori groups.”294

At a formal Ngāi Tahu-Crown negotiation session in late March 1993, the Crown noted that further work was still to be done on the envelope. "Ngāi Tahu again complained at the lack of consultation over the envelope concept and reminded the Crown of its Treaty

\footnotetext{
${ }^{292}$ Waitangi Tribunal, The Ngai Tahu Report, 347-790; Harry C. Evison, New Zealand Racism in the Making: The Life \& Times of Walter Mantell (Lower Hutt: Panuitia Press, 2010).

${ }^{293}$ O’Regan to Graham, 1 February 1993, C-27-2-02 Vol. 2, OTS archive; ToWPU official 3, "Analysis of the Ngāi Tahu report of the Negotiation Process and Position,” 4 March 1993, C-27-2-02 Vol. 2, OTS archive.

294 Adella Ferguson, “Treaty package claimed,” New Zealand Herald, 18 May 1993.
} 
obligations ‘actively to protect’ Ngāi Tahu’s interests. Ngāi Tahu noted there may be constraints to the envelope as an effective tool for use in the settlement of claims, particularly if it is to include wāhi tapu and fiscally neutral matters. Consultation should take place if the envelope is to be more than an internal management mechanism for the Crown." ${ }^{295}$ Ngāi Tahu was expressing its concern with the Crown's unilateral development of "the envelope concept” as a whole, but especially those aspects that did not involve compensation. The Crown argued that the length of time it would have taken for the development of the fiscal envelope policy would have been extended even further if consultation with Māori around the country was necessary. Ngāi Tahu charged that the policy was not "an internal management mechanism”, but a tool for the settlement of claims and as such Ngāi Tahu, and other iwi, should be consulted regarding its development. The envelope approach quickly exasperated Ngāi Tahu negotiators, who were being increasingly pressured by their own constituency. In some ways Ngāi Tahu negotiators had dug themselves a hole by creating such high expectations for Ngāi Tahu members. The Crown was developing its policy in isolation from claimants as well as the public — the process was completely internal. Government policy cannot always be developed with the help of those who it affects most, but in this case it was especially difficult for Māori negotiators such as Ngāi Tahu.

At the end of 1993 O’Regan's annual report to the NTMTB summarised the difficulties that the negotiating group experienced with the Crown during the previous year. O'Regan stated that the Crown had attempted to propose the idea of the "envelope" to Ngāi Tahu but that Ngāi Tahu negotiators had rejected the concept. "There has clearly been a battle going on within the Crown about the concept itself and about the overall quantum of financial provision that the Crown is willing to make towards Treaty settlement. The danger of creating a lolly scramble, by which the Māori tribes fight with each other over available

\footnotetext{
295 "Meeting between Ngāi Tahu and Crown Negotiators," 31 March 1993, C-27-2-02 Vol. 2, OTS archive
} 
settlements, is very real.” O'Regan stated that Ngāi Tahu understood that it could not receive full compensation from the Crown for its loss, but that it required the Crown to provide at least some basic type of rationalisation. "The Crown's inability to make up its own mind about the issue of quantum on a basis which is even morally defensible, let alone financially defensible, has been a huge problem to the negotiation.” The one small note of optimism which O'Regan noted in relation to the negotiations was that the improvement in the economy could favour a more reasonable fiscal approach by the Crown. ${ }^{296}$

The work commissioned by Ngāi Tahu to estimate the value of its loss was set aside by the Crown. The fisheries settlement and the fiscal envelope policy would establish a new benchmark and set a fiscal cap, divorced from iwi estimates of loss. Waikato-Tainui would have to cope with the precedent of the fisheries settlement, and the gradual development of the fiscal envelope policy just as Ngāi Tahu did. Like O’Regan, Mahuta was also a conegotiator on behalf of Māori for the fisheries settlement. Both O’Regan and Mahuta, in their roles as chief negotiators for their iwi, would have to work under the fiscal parameters established by the Settlement Fund and the fisheries settlement signed two days later in September 1992.

\section{Part II: Waikato-Tainui's Treaty settlement, the fiscal envelope and the relativity clause}

\section{Waikato-Tainui, the fiscal envelope and finality}

During the same period, Waikato-Tainui also came to oppose the fiscal envelope policy. From the commencement of their negotiations with the Labour government, the predominant focus for Waikato-Tainui was on securing the remaining Crown-owned land in the area for their settlement, in line with their key negotiating principle that "as land was

\footnotetext{
${ }^{296}$ O’Regan, “Chairman’s Report,” Ngāi Tahu Annual Report 1993, NT140 C4, Box 54, MB archive, 7-9.
} 
taken so land must be returned” (“i riro whenua atu me hoki whenua mai”). This remained the case with the National government as well. From November 1991 (when their negotiations with National began) to September 1992 (when the fisheries settlement was signed), Waikato-Tainui and the Crown largely worked through the logistics of the transfer of Hopuhopu and tried to develop an agreement under which further land would be transferred to Waikato-Tainui. Nonetheless Waikato-Tainui negotiators also concentrated on establishing the value of their loss, and attempted to insert the estimated value of this loss into their Deed of Settlement. Waikato-Tainui had not concerned itself with the type of valuation exercises that Ngāi Tahu had commissioned for its own claim. Nonetheless, both negotiations were equally influenced by the effect of the fiscal envelope policy. The problems associated with the fiscal envelope policy became tied up with Waikato-Tainui’s settlement during its final settlement negotiation.

Denese Henare, the senior legal advisor for Waikato-Tainui, had early concerns about the effect that the fiscal envelope policy would have on the amount Waikato-Tainui would receive through its settlement, particularly how it might affect the return of land. In relation to clause 4.6 of the 1992 fisheries Deed of Settlement which referred to a "settlement fund," Henare sought a written undertaking from Minister of Justice and principal Crown negotiator for both the fisheries and Waikato-Tainui negotiations, Doug Graham, that this clause would in no way preclude or undermine the "land for land" principle which was central to WaikatoTainui's raupatu claims. ${ }^{297}$ Although Graham gave his assurances, Waikato-Tainui soon became confined to the fiscal precedent of the fisheries settlement. Although the nature of the settlements differed, the $\$ 170$ million figure would become a benchmark for a settlement of the scale of Waikato-Tainui.

\footnotetext{
${ }^{297}$ Henare to Graham, 29 September 1992, TC30 Vol. 25, OTS archive.
} 
In early March 1993 Graham informed Mahuta that Cabinet was close to formally announcing the fiscal envelope policy, and that Waikato-Tainui would be offered a $\$ 170$ million settlement. Graham advised Mahuta to develop a proposal for the assets WaikatoTainui desired as part of their settlement. Mahuta envisioned that each of the 33 hapu affiliated with the Tainui Māori Trust Board would receive two farms. In addition the Crown would also transfer to the iwi the Maramarua and Onewhero Crown Forests, all Coalcorp surplus lands, and commercial railways surplus lands in Hamilton. The Crown would also provide funding to establish two Endowed Colleges at the University of Auckland and University of Waikato and at international universities in the United States and United Kingdom. ${ }^{298}$ At the same time Mahuta also asked financial advisor Brent Wheeler to calculate the potential profit on a $\$ 170$ million investment. ${ }^{299}$ Wheeler wrote a long memorandum to Mahuta setting out the possibilities for settlement within the Crown's new fiscally restrictive parameters. Wheeler thought that the "logic" of the unofficial \$170 million proposal was based on fiscal prudence rather than a mathematical formula. ${ }^{300}$

In mid-May 1993 Graham and Mahuta met alone in Wellington without any advisors or officials present. Graham stated that he understood that only a land for land approach would be accepted by the wider Waikato-Tainui people but that the Waikato-Tainui settlement would have to be taken from the total fiscal cap which would be set at $\$ 1$ billion. Graham again informed Mahuta that Waikato-Tainui would be offered a \$170 million settlement. Mahuta had indicated to Graham that the offer would need further consideration if Graham was “talking about full and final.” ${ }^{301}$ The question of whether the Crown’s offer was enough to settle the claim for all time soon came to define debates between the parties. The

\footnotetext{
298 Mahuta to Henare, 2 March 1993, RC Vol 30 1993, Box 11, W-T archives.

${ }^{299}$ Wheeler estimated returns of 7-9\%: Henare to Mahuta, 4 March 1993, RC Vol 30 1993, Box 11, W-T archives.

${ }^{300}$ Wheeler to Mahuta, 20 May 1993, RC Vol 30 1993, Box 11, W-T archives.

${ }^{301}$ Mahuta, “Diary Note,” 18 May 1993, RC Vol 301993 Box 11, W-T archives.
} 
day after Mahuta and Graham met privately, Crown and Waikato-Tainui advisors also met. The advisors' discussion focused on whether the proposed settlement fund would affect the amount of land Waikato-Tainui might obtain through the settlement. The Secretary of Justice claimed that Waikato-Tainui's principles that "as land was taken so land must be returned" were still accepted and possible under the Crown's new arrangements. The concern from Waikato-Tainui's advisors was on the finality of a fiscally limited arrangement which would not allow for the return of all Crown lands in the region: could the proposed settlement be durable if an inadequate amount of land was transferred? The advisors also commented that furthermore if the settlement was seen to be imposed rather than negotiated, would it be accepted by the Waikato-Tainui people? ${ }^{302}$ The $\$ 170$ million figure was far below the total value of government land remaining in the Waikato-Tainui confiscation area. ${ }^{303}$ The Crown explained to Waikato-Tainui negotiators that compensation could not be linked to the loss of land but that the level of compensation would be an entirely political decision-Ministers with the help of their officials would determine what was a fair but fiscally affordable settlement. In this case that political decision was establishing the fisheries settlement $\$ 170$ million quantum as the benchmark, and applying the quantum to the Waikato-Tainui raupatu claim despite the significant differences between the two sets of claims. ${ }^{304}$

After Graham informed Mahuta privately of the planned \$170 million offer in May 1993, the negotiations came to a standstill. The development of the fiscal envelope policy would extend over another year and a half. Waikato-Tainui’s negotiations with the Crown were also interrupted by the 1993 election. After National won the election, Mahuta wrote to

\footnotetext{
302 “Meeting between Crown and Waikato Advisors,” 19 May 1993, RC Vol 301993 Box 11, W-T archives. Unfortunately the OTS has been able to find any of the files related to the Waikato negotiations from January 1993 to the end of September 1994 so I cannot determine whether comments on the meeting appeared in the correspondence of Crown officials. No evidence of the meeting exists in Graham's files.

${ }^{303}$ The value of government land in the Waikato-Tainui confiscation area varied from over a \$1 billion in 1989 to under \$1 billion by 1994.

${ }^{304}$ Mahuta, “Diary Note,” 18 May 1993, RC Vol 301993 Box 11, W-T archives.
} 
the new Minister of Finance, Bill Birch in December 1993. ${ }^{305}$ Mahuta asked that the government urgently arrange a meeting of the Ministers of Finance, Māori Affairs, Justice, Prime Minister and Māori leaders to discuss the Crown’s fiscal envelope policy. ${ }^{306}$

In mid-February 1994 the pan-Māori hui sought by Mahuta was secretly held by Graham and Māori Affairs Minister John Luxton. The fiscal envelope policy was introduced to a large gathering of Māori leaders in Rotorua, but there was no press coverage. Graham announced that the fiscal limit for Treaty settlements would be $\$ 1$ billion for all claims, including the fisheries settlements negotiated in 1989 and 1992. The Crown announced that the fiscal envelope concept was a mechanism for the Crown's own fiscal management. The Crown did not seek the agreement of Māori to either the concept of the fiscal envelope or the total amount of compensation proposed. Nonetheless the Crown held that the envelope would need to be large enough to result in fair and durable settlements that would provide certainty to all parties. The settlements would need to be fair between individual claimants and the Crown, and between claimants themselves. Ngāi Tahu was not invited by the Crown and learned about the hui through other channels. In the end Ngāi Tahu Māori Trust Board (NTMTB) member Charles Crofts and NTMTB Secretary Sid Ashton were able to attend. All Māori leaders that attended, including Waikato-Tainui represented by Mahuta, rejected the notion of a fiscal limit for Treaty settlements. ${ }^{307}$ The reality of the Crown’s stance had set in for Waikato-Tainui and Mahuta as he made clear in a memorandum to Denese Henare shortly after the February 1994 hui. "My understanding is that Bill Birch has insisted on the cap and within that the Minister and TOWPU have put together the various envelopes which they are now offering piecemeal to the various claimants. Whilst I agree that

\footnotetext{
305 Jack Vowles, Towards consensus? (Auckland: Auckland University Press, 1995).

${ }^{306}$ Mahuta to Birch, 13 December 1993, RC Vol 32, Box 12, W-T archives.

307 Sid Ashton, "Pan-Māori Forestry Hui," 12 February 1994, Vhi 15 (n), TRONT archive; Shane Solomon, “CFRT hui,” RC Vol 33, Box 13, W-T archives.
} 
it is difficult for us to get an overall handle on the lands being offered to Waikato, at least this is some progress on what the former Labour government offered.”308

After the fiscal envelope hui, Waikato-Tainui and the Crown did not formally meet until April 1994. During this first negotiation session of 1994 there was discussion of the implications of a fiscally limited settlement on the potential durability of the settlement. Graham stated that any settlement would have to be full and final. ${ }^{309}$ Both of WaikatoTainui’s legal advisors, Denese Henare and Shane Solomon, were distressed by the Crown's focus on finality. Their most significant concern was the extinguishment of Waikato-Tainui's customary rights for an amount that they considered was less than what their Treaty claims deserved. Given that the 1946 settlement had also been "final”, there was perhaps not so much cause for unease. ${ }^{310}$ Nonetheless Mahuta remained concerned. At the April 1994 meeting Graham had asked Mahuta to put the present offer of \$170 million back to the Waikato-Tainui people. Mahuta responded to Graham and ToWPU officials that presenting such a limited settlement would be difficult. He stated: “Any attempt at this point to extract agreement on a 'full and final' commitment is not on!”311 Once it became apparent that the issue of finality was necessary for the Crown's own internal processes, Mahuta tried to convince Graham that finality would be difficult to guarantee.

In mid-September 1994 the Crown’s Treaty settlement policy, including details about the \$1 billion cap for all settlements and conservation and natural resource claims was leaked to the media. Mana News had obtained copies of the draft Crown policy booklet being developed for release to the public and they reported that natural resources and conservation lands would not be available as redress. Soon thereafter, in early October 1994, Waikato-

\footnotetext{
${ }^{308}$ Mahuta to Henare, 17 March 1994, RC Vol 33, Box 13, W-T archives.

309 "Meeting between Crown and Waikato negotiators, 14 April 1994,” AAKW W5105 7812 22, Archives NZ

${ }^{310}$ Solomon and Henare memoranda, 14 April 1994, RC Vol 33, Box 13, W-T archives.

${ }^{311}$ Mahuta to ToWPU official 4, 18 April 1994, RC Vol 33, Box 13, W-T archives.
} 
Tainui produced a categorical rejection of the Crown's fiscal envelope policy and challenged its position on natural resources and conservation land in Kia Hiwa Raa, a Tainui Māori Trust Board publication. ${ }^{312}$ Waikato-Tainui would continue to challenge the Crown's position on the fiscal envelope throughout their negotiations, even as they negotiated a settlement.

In September 1994, Henare provided a stringent critique of the Crown's full and final position in a memorandum to Mahuta. She recounted Mahuta's comments at the March 1990 meeting of Waikato-Tainui and the Crown. Mahuta had responded to a focus on finality by Justice Minister Bill Jeffries by asking: "where in the world were there examples of full and final settlements which had not been affected by change?” Henare commented that:

[t]his Government and previous Governments have been concerned to preserve their own set of principles to enable them to avoid legal and Treaty principles. The acknowledgement that the ToW [Treaty of Waitangi] is the nation's founding document is capable of easy acceptance when the Crown interprets for itself the rights and obligations under the Treaty. This is the political response which has led to Crown Law arguing for deconstruction of the Treaty at Waitangi Tribunal hearings...If the Crown 'downs its tools' because it insists on full and final when also arguing economic and political capacity then that will be a decision for it to make. History will view that decision as unreasonable. ${ }^{313}$

To Henare the notion of a full and final settlement was arbitrary if it was not connected directly to some kind of evaluation of loss, and based instead on a feeling shared by Ministers that a settlement was fair. Henare questioned why the Crown could not use the legal and Treaty principles that had been formed by the landmark court cases involving the New Zealand Māori Council in 1987 and the Tainui Māori Trust Board in 1989, and the early work of the Waitangi Tribunal, in determining its principles for settlement. To Henare the Crown's unilateral development of the proposed amount of compensation of quantum ignored the important Treaty principles that had been formed.

\footnotetext{
${ }^{312}$ Kaa Hiwa Raa, October 1994; Mana News, “Crown settlement policy,”15 September 1994, AAKW W5105 7812 4, Archives NZ.

${ }^{313}$ Henare to Mahuta, 19 September 1994, RC Vol 34, Box 13, W-T archives, 2.
} 
Following Henare's memoranda on finality, Mahuta wrote a series of letters to Graham in late September 1994, in which he began to set out a case based on the value of the land Waikato-Tainui sought for return through the settlement. According to Mahuta the terminology of full and final agreements was anachronistic and the negotiations would be better served without it. Mahuta tried to explain to Graham that it was impossible to bind the next generation. Nonetheless Mahuta stressed that Waikato-Tainui also wanted a durable settlement that would endure for generations. In order to achieve such durability, Mahuta proposed a settlement valued at \$990 million to allow for "tribal restoration and the purchase of land in the private market.” Mahuta believed that the $\$ 990$ million figure was the capital value (land and improvements) of the remaining lands in the Crown's ownership in the Waikato-Tainui confiscation area. According to a ToWPU official's calculations the figure was closer to $\$ 760$ million. Mahuta stated that any proposed settlement below that value would not be accepted by the Waikato-Tainui people. ToWPU officials and Graham were surprised by Mahuta’s request for a $\$ 990$ million settlement. The lead ToWPU official for the Waikato-Tainui negotiations warned Mahuta that it was unlikely that Cabinet would agree to the $\$ 990$ million proposal as it so overtly challenged the parameters of the fiscal envelope. Graham was already experiencing difficulties obtaining Cabinet’s approval for the \$170 million proposal. ${ }^{314}$ Mahuta did not press the issue following the negative response from the Crown, but the concern with ensuring that the settlement was ratified by Waikato-Tainui communities remained. In an October 1994 memorandum Shane Solomon noted following a meeting between Crown and Waikato-Tainui negotiators that "the problem would be when [Graham] states to cabinet that it will be full and final and [Mahuta] states to the people that it

\footnotetext{
${ }^{314}$ Mahuta to Graham, 23 \& 24 September 1994, RC Vol 34, Box 13, W-T archives; ToWPU official 4 to Mahuta, 28 September 1994, RC Vol 34, Box 13, W-T archives; CAB (94) 876; CSC (94) 121; CSC (94) 129, AAKW W5105 7812 22, Archives NZ.
} 
will not be.” Solomon believed that consistency was necessary above all since each group knew that "neither can bind the future."

About a month after aspects of the Crown's Treaty settlement policy was leaked to the media, the Crown made its first formal settlement offer to Waikato-Tainui in mid-October 1994. Justice Minister Doug Graham instructed a ToWPU official that was drafting the

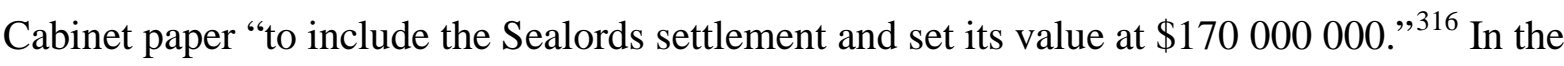
final version of the Cabinet paper the nominal value of the land returned and cash to purchase further land would total \$170 million. Cabinet noted that the \$170 million figure "constitutes the maximum fiscal element of a final and durable settlement of the Waikato-Tainui raupatu claim" and that "a settlement would represent compensation for $7 \%$ of the land confiscated." ${ }^{317}$ It is unclear how Cabinet calculated that the value of $7 \%$ of the land that was confiscated was $\$ 170$ million. ${ }^{318}$ Further fiscal matters were still to be added to the settlement such as the payment of interest on the unpaid sum and the Right of First Refusal (RFR). ${ }^{319}$ The settlement excluded the rivers and harbours aspects of the Waikato-Tainui claim. ${ }^{320}$ Waikato-Tainui were forwarded a draft copy of the government's natural resources policy which did not recognise any Māori ownership interests in natural resources. ${ }^{321}$ Graham wanted to ensure that the Crown's Treaty settlement policy and the announcement of a

\footnotetext{
315 ToWPU official 4, "Meeting between Crown and Waikato negotiators,” 12 October 1994, TC30 Vol. 38, OTS archive; Solomon, "Meeting between Crown and Waikato negotiators,” 12 October 1994, RC Vol 34, Box 13, W-T archives, 3 .

${ }^{316}$ ToWPU official 9, "File Note, Re: Meeting”, 4 October 1994, TC30 Vol. 37, OTS archive.

${ }^{317}$ CAB (94) M 37/7; CAB (94) M 37/8; ToWPU official 9, “”, 4 October 1994; ToWPU official 4, "file note”, 7 October 1994, TC30 Vol. 37, OTS archive.

${ }^{318}$ If the $\$ 6$ billion figure from 1989 is taken as the value of all the land confiscated in the Waikato raupatu area then $7 \%$ would be $\$ 420$ million.

${ }^{319}$ The issue of interest was discussed early on by Tipene O'Regan, he mentioned that such limited compensation would have to accrue interest if it was not paid out all at once: Jonathan Underhill, "Treasury setting land claims limit,” 7 March 1993, Sunday Star Times.

${ }^{320}$ The rivers and harbours had initially been on the negotiating agenda, but were gradually phased out during the negotiations with National in the early 1990s when it became apparent that a settlement of both the land and harbours and rivers claim would be too complicated to complete in a short amount of time.

${ }^{321}$ Graham to Mahuta, 19 October 1994, TC30 Vol. 38, OTS archive. In addition, non-fiscal matters such as the provision of a guaranteed seat on the Waikato Conservation Board were yet to be included.
} 
settlement with Waikato-Tainui would occur concurrently. For the Crown the $\$ 170$ million benchmark figure and the development of the fiscal envelope were connected, because Waikato-Tainui's settlement would entrench the precedent set by the fisheries settlement. ${ }^{322}$

When Waikato-Tainui responded to the first draft Heads of Agreement sent by the Crown, the different positions on the issue of finality were apparent from the revisions Waikato-Tainui requested. The Crown's draft stated that the "Crown has acted honourably and reasonably, that the settlement satisfies both the moral and legal obligations of the Crown under the Treaty of Waitangi and its principles or otherwise in relation to the Claims and that the settlement is fair, final and durable." Waikato-Tainui would only state that the "Crown has acted." Waikato-Tainui's version of the Heads of Agreement would state that the settlement had achieved only "certainty and durability...because the current legislation cannot provide for settlement that is full." ${ }^{323}$ Waikato-Tainui attempted to address the discrepancy between their own view of the limited settlement on offer and the Crown's view with a relativity clause.

322 ToWPU official 9, "File Note, Re: Meeting”, 4 October 1994, TC30 Vol. 37, OTS archive.

${ }^{323}$ Mahuta to Graham, "HoA Draft,” 25 October 1994, TC30 Vol. 38, OTS archive. 


\section{Waikato-Tainui and the relativity clause}

It is unclear exactly when Waikato-Tainui first proposed the relativity clause to the Crown and who within the Waikato-Tainui negotiating team first had the idea. One source believed that financial advisor Brent Wheeler had come up with the idea. ${ }^{324}$ The clause stemmed from concern within Waikato-Tainui that the Crown had provided a fiscally limited settlement, had not recognised the significance of their claims and their willingness to settle first. Although the relativity clause would not be developed formally until the Heads of Agreement was first drafted in October 1994, it was discussed earlier in the negotiations. In April 1994 Mahuta stated during a meeting with the Crown that the principle of "full and final” was "an out dated concept...use Waikato as benchmark, all other claims will be relative to ours or all bets are off.”325 Waikato-Tainui were concerned that the $\$ 170$ million figure was not based on a calculation of loss, but rather the precedent of the fisheries settlement and the Crown's desire to limit the total amount paid to all Māori groups through Treaty settlements. After receiving the first draft of the Heads of Agreement from the Crown in late October 1994, Waikato-Tainui responded with changes that included a rudimentary form of the relativity clause: “The Crown acknowledges that the Waikato-Tainui claim is the biggest claim to settle as lands taken at the point of a musket is more grievous than lands taken through an unfair purchase. All other settlements will be relative to the Waikato-Tainui claim. This claim will be re-opened at any time if that is relativity is compromised.” ${ }^{326}$ From late October to mid-November 1994, Waikato-Tainui negotiators and advisors attempted to have a variation on the quote above placed into the Heads of Agreement to ensure the relativity of Waikato-Tainui's claim to all other claims, but there was resistance from the

\footnotetext{
${ }^{324}$ Interview with Nanaia Mahuta, 12 January 2011.

325 Shane Solomon, "Meeting with the Crown”, 21-22 April 1994, RC Vol 33, Box 13, W-T archives.

${ }^{326}$ Mahuta to Graham, "HoA Draft,” 25 October 1994, TC30 Vol. 38, OTS archive.
} 
Crown. The CLO felt that such a statement would pre-judge the negotiations of other claimants in the future. ${ }^{327}$

Mahuta continued to pressure the Crown to enlarge its offer because a limited offer would be rejected by the Waikato-Tainui people as Labour's 1990 settlement offer had been. After Solomon and Waikato-Tainui financial advisor Brent Wheeler met with Graham and ToWPU officials in November 1994 to discuss the Crown's offer, Wheeler faxed the proposed limited acreage to Mahuta who commented: "no way will the people accept this as full and final!” ${ }^{228}$ Wheeler thought that the "price" being offered by the Crown was "woefully inadequate and unnecessarily (on the Crown's part) conservative." Nonetheless, according to Wheeler, the Waikato-Tainui negotiators and the people themselves had to decide if there was a price at which a full and final settlement would be possible, or if it was a matter of principle that could not be overcome. If there was a price, it would need to be determined. ${ }^{329}$

Despite the concerns of the leadership with the fiscally limited offer, Waikato-Tainui negotiators still recommended that the iwi consider the offer. Waikato-Tainui marae were informed at the start of November 1994 that the upcoming month would be busy with mandating processes to decide whether or not to accept the Crown's settlement offer. The October and November issues of Kia Hiwa Raa had outlined the historical issues of raupatu and the negotiations to that date. Mahuta stated that the Crown only had 90,000 acres remaining in the raupatu rohe and of that total 47,000 acres was Department of Conservation (DoC) land that the Crown claimed was unavailable for transfer. Mahuta contended that the

\footnotetext{
${ }^{327}$ Mahuta to Graham, 18 November 1994, TC 30 Vol. 40, OTS archvie \& RC Vol 36, November 1994, Box 14, W-T archive; Solomon to ToWPU official 3, 3 November 1994, TC30 Vol. 39, OTS archive.

${ }^{328}$ ToWPU official 4 to Graham, 7 November 1994, TC30 Vol. 39, OTS archive; Mahuta, "file note”, 8 November 1994, RC1, Correspondence Vol 36, November 1994, Box 14, W-T archives; Richard Knight, "Waikato tight lipped on possible govt offer to settle land claim", 8 November 1994, Waikato Times; "Waikato chairman gives no clues over land settlement proposal", 10 November 1994, Waikato Times.

${ }^{329}$ Brent Wheeler to Mahuta, 15 September 1994, RC Vol 33, Box 13, W-T archives.
} 
DoC land was still the subject of negotiations. ${ }^{330}$ Mahuta was forthright with marae representatives about the short opportunity that the iwi had to negotiate an agreement with the Crown. While this could have been seen as a way to pressure beneficiaries Mahuta was merely stating what was perceived by many to be a harsh political reality: "It is likely that this will be the first and last offer this current Government will make before the next general election...The Crown wishes to achieve at least one significant settlement and views the Waikato raupatu claim as the largest Maaori claim. The Crown seeks to settle the claim before next year's election campaign takes control of Wellington, and before MMP which is likely to prevent any settlements of Maaori claims occurring at least in this generation.”331 Although Mahuta turned out to be incorrect, the political environment of Treaty settlements surely would have been greatly affected if Waikato-Tainui had not signed their settlement to set the process in motion.

In mid-November 1994 the Crown provided a second draft of the Heads of Agreement to Waikato-Tainui but it did not contain many of the changes that Waikato-Tainui had sought. ToWPU, perhaps reflecting CLO advice, recommended that Graham should accept Waikato-Tainui’s cosmetic changes but reject the requested change regarding finality and fairness. ${ }^{332}$ At Tainui Māori Trust Board hui members had repeatedly expressed concerns with the full and final nature of a fiscally limited settlement that would not allow for the transfer of the lands remaining in the Crown's ownership in the Waikato. ${ }^{333}$

At a meeting of the Tainui Māori Trust Board in late November 1994 the issue of finality was discussed at length with members of the Board holding different views on the

\footnotetext{
${ }^{330}$ Kia Hiwa Raa, October 1994; Kia Hiwa Raa, November 1994.

${ }^{331}$ Mahuta to Maraes, 1 November 1994, RC1, Correspondence Vol 36, November 1994, Box 14, W-T archives.

${ }^{332}$ Mahuta to Graham \& ToWPU official 4 to Graham, 11 November 1994, TC30 Vol. 39, OTS archive.

${ }^{333}$ Mahuta to Graham, 14 November 1994, TC30 Vol . 39, OTS archive.
} 
meaning of "full and final”. Board member Carmen Kirkwood referred to the negotiations as an "evolutionary process with a full and final settlement”, one that would take longer than just the present generation. Kirkwood felt that the agreement may record the settlement as full and final but that the negotiations would not be complete until Waikato-Tainui received back the approximately 1.2 million acres that it had lost. This point by Kirkwood encapsulated how amorphous the concept of full and final could be to different people. Waikato-Tainui advisor Shane Solomon re-emphasised the relative nature of full and final settlements: "Full and final has never happened anywhere else but here. Full and final settlements have been re-opened.” The Board felt that it could not be considered a "full and final settlement because there are lands in [the] Waikato that the Crown wants to hold onto.” Different members of the Board accepted that it could be referred to as a "full settlement" but it would not be “final” until Waikato-Tainui’s goals were met. Board member Rovina Maniapoto-Anderson concluded that "there are 2 issues of full and final." "Firstly, as far as the Government is concerned and secondly, as far as we are concerned. As far as the Government is concerned, that is all they have got."334 These debates over finality show the difficulties that Waikato-Tainui negotiators faced from within their own communities to accept the limited settlement on offer.

When Waikato-Tainui and Crown advisors met in mid-November 1994 the discussion turned to the need for Waikato-Tainui to have the equivalent of 90,000 acres transferred. Otherwise, Waikato-Tainui advisors stated, the settlement would not be considered full or final by the iwi. Off the record Crown officials were at pains to emphasise that the issue of finality was a political necessity for Cabinet. ${ }^{335}$ After a meeting of Waikato-Tainui and Crown advisors and officials, Waikato-Tainui advisor John Te Maru asked ToWPU officials

\footnotetext{
${ }^{334}$ Tainui Māori Trust Board, "Raupatu Hui,” 23 November 1994, 94 Aug-Dec (SS) Box 32, W-T archive. ${ }^{335}$ Solomon \& Mahuta memoranda, 22 November 1994: RC1, Correspondence Vol 36, November 1994, Box 14, W-T archives.
} 
to "provide a clear definition as to what any full, final and durable settlement may refer to especially its relationship to raupatu land claims and any associated property rights, including natural resource rights.” The concern with full and final issues led to Waikato-Tainui asking the Crown to explore possible interim settlements because they felt that the Crown's proposed settlement would be rejected by the Waikato-Tainui people. ${ }^{336}$

During the second half of November 1994 the relativity clause and the issue of finality began to appear frequently. At a late November 1994 meeting between ToWPU officials and Waikato-Tainui advisors, the lead OTS official advised their Waikato-Tainui counterpart that she would seek direction on whether the Crown was "willing to consider 'benchmarking' the compensation package to Tainui to $20 \%$ of the total settlement 'package' relating to Treaty of Waitangi issues.” At that time Waikato-Tainui had understood the total amount provided for land claims to be $\$ 850$ million, with a subsequent offer of $\$ 170$ million to Waikato-Tainui. ${ }^{337}$ By the third draft of the Heads of Agreement the Crown had agreed to insert a provision for some kind of relativity clause: “The quantum represents $17 \%$ of the total envelope (or approximately 20\% of land claim settlements).”338 The clause was now embedded into the agreement and would appear in future drafts but permission to include the clause would not occur until the night that the Heads of Agreement was signed. ${ }^{339}$

While the Crown's fiscal limit on the total value of Treaty settlements had been rejected in many ways by Waikato-Tainui and other Māori groups by December 1994, the Bolger government received its first official rejection early that month when Te Arikinui and paramount Ngati Tuwharetoa leader Sir Hepi Te Heu Heu refused to attend the Crown's presentation of its Treaty settlement policy at Premier House on 7 December 1994. Although

\footnotetext{
${ }^{336}$ John Te Maru to ToWPU official 4, 25 November 1994, 94 Aug-Dec (SS) Box 32, W-T archive.

${ }^{337}$ Ibid.

338 Graham to Mahuta, “HoA Draft,” 29 November 1994, TC30 Vol. 40, OTS archive.

339 Graham to Mahuta, "HoA Draft,” 9 December 1994, TC30 Vol. 41, OTS archive.
} 
Waikato-Tainui was in the middle of intense negotiations with the Crown, TMTB members publicly criticised the $\$ 1$ billion cap but acknowledged the courage of the Crown for attempting to settle Māori grievances. Mahuta stated that if the government wanted the settlements to be full and final then the Crown would need to increase the limit. The New Zealand Herald editorial criticised the manner in which the fiscal envelope policy was forced upon Māori. A diverse group of politicians of different political stripes and authors opposed the fiscal cap in mid-December 1994: Labour Treaty Issues Spokesperson David Caygill, Alliance co-leader Sandra Lee, National MP Michael Laws, author Alan Duff, former Prime Minister David Lange and National Party Māori Vice-President Cliff Bidwell. The Sunday Star Times was one of the few newspapers which commended the Crown for at least building a starting point for negotiations. ${ }^{340}$ The National Business Review also supported the Crown’s new policy, although economist Gareth Morgan provided a stringent critique of the limits and unilateral development of the fiscal envelope from within the NBR's pages early in February 1995..$^{341}$

The fiscal envelope policy was widely criticised at the time. The fiscal limit proposed by the Crown was too small to account for all of the Treaty settlements that would need to be negotiated and it was officially abandoned in the coalition agreement following the 1996 election. The criticism of the fiscal limit was and continues to be reasonable, but the media seemed to focus overtly on the fiscal cap, as opposed to the whole package of proposals.

\footnotetext{
${ }^{340}$ Andrew Stone, “Cool welcome for 'fiscal envelope”, 9 December 1994, New Zealand Herald; "Govt land claim offer an 'insult"', 9 December 1994, Waikato Times; "Flexing the Envelope", 9 December 1994, New Zealand Herald , "National Māori vice-president [Cliff Bedwell] criticises cap", 10 December 1994, Waikato Times; Andrew Stone, "Debate on treaty plans constructive, moderate", 10 December 1994, New Zealand Herald ; Michael Laws, "Arrogant land proposal doomed", 11 December 1994, New Zealand Herald; "Settlement starter", 11 December 1994, Sunday Star Times; Alan Duff , "Brave move, but \$1b too low", 13 December 1994, Waikato Times; David Lange, "Government ignores responsibilities”, 19 December 1994, Waikato Times.

${ }^{341}$ Solomon to Te Maru, 11 January 1995; Solomon, “file note,” 24 January 1995, RC1, Correspondence Vol 37, December 1994, Box 15, W-T archives ; "Fiscally fair and timely", National Business Review, Vol 25 No 43 Issue 1906; Gareth Morgan, "'Want to know why the fiscal envelope is so thick?" National Business Review, 10 February 1995.
} 
Other major issues were the lack of consultation with Māori during the development of the policy and the policy's focus on grievances stemming from confiscation rather than the Native Land Court, and the uncompromising position of the Crown which refused to recognise ownership interest in natural resources (other than pounamu), and severely limited the transfer of conservation land. ${ }^{342}$ Nonetheless Crown officials who were involved in the Waikato-Tainui negotiations and general Treaty settlement policy maintain that another settlement after the fisheries settlement would not have been possible without a fiscal cap. Many of the same officials stressed that a considerably larger sum was recommended by ToWPU and TPK officials, but Treasury advice dominated the debates over a fiscal limit. ${ }^{343}$ Only days before the signing of the Heads of Agreement in late December 1994 Henare and Mahuta remained concerned about the finality of the settlement. Henare wrote to Mahuta:

As you are aware, I do not agree with the Crown's offer because of its full and final nature; what Waikato is being asked to surrender, the very limited rights in respect to the lands being returned; the lack of redress and leverage by a 'full and final settlement' and generic policy to the Waikato River, the Crown's approach to coal, minerals and the conservation lands...

Henare wanted the Crown to agree to a much larger settlement that would allow for the transfer of all remaining Crown lands in the region. The refusal of the Crown to include natural resources and conservation lands was indicative of the limits of the settlement on offer from Henare’s perspective. She felt that the Crown's uncompromising position would result in a settlement that would not endure for generations. The Crown stressed that the agreement had been negotiated "honourably, reasonably...fair, final and durable.” To Henare the notion of a fair and reasonable agreement was impossible if there was undue pressure and

\footnotetext{
${ }^{342}$ Mutu, The State of Māori Rights, 21-25; Aroha Harris, Hikoi: Forty Years of Māori Protest (Wellington: Huia Publishers, 2004) 124-133; Belgrave, Historical Frictions, 330-331; Walker, Ka Whawhai Tonu Matou, 301-304; Ward, An Unsettled History, 52-53.

343 Graham, Trick or Treaty?, 55-67; Graham, “The Treaty and Treaty Negotiations,” 166-169; Interview with ToWPU official 4, 24 May 2011; Interview with ToWPU official 1, 27 July 2011; Hill, Māori and State: Crown-Māori Relations in New Zealand/Aotearoa 1950-2000, 262.
} 
what she viewed as an "abuse of process" because of the Crown's overriding control of the process. ${ }^{344}$ Mahuta also remained doubtful whether the quantum was large enough to provide the "fullness and finality" sought by the Crown. ${ }^{345}$

By mid-December 1994 the signing of a settlement with Waikato-Tainui was still not assured when two of Mahuta's advisors, Denese Henare and Peter Rowe, as well as internal opposition from within the iwi (Dr. Ngapare Hopa, Eva Rickard, Ngāti Whawhakia and Ngāti Wairere hapū), recommended that their negotiators not accept the Crown's settlement proposal. ${ }^{346}$ Mahuta appreciated Henare's concern and has commented elsewhere about how much he appreciated Henare’s advice. ${ }^{347}$ Henare's concerns were completely valid and she performed over and beyond her role but Mahuta admitted that after such a long struggle it was perhaps the right time to settle:

I am aware that you are not too happy with the process thus far and the way in which the politicians are continually trying to hijack the negotiations. At the same time I detect a groundswell of opinion amongst our people who are saying 'now is the time to seek a settlement of raupatu. Negotiate the best deal we can but let us settle this aspect of raupatu now.' This will give us breathing space before we lodge our next onslaught which is the river and West Coast harbours claim. I know that this is a far from perfect deal but it will enable Waikato to gain some semblance of control over its future. Perhaps the years of struggle are finally taking their toll on me, hence my willingness to support settlement. I am conscious of the games the Crown continues to play and your own repeated warnings of the implications our settlement might have on the rest of Maaoridom and the Treaty.

\footnotetext{
${ }^{344}$ Henare to ToWPU official 4, 19 Deccember 1994, TC30 Vol. 42, OTS archive, 1; Henare to Mahuta, 19 December 1994; Rowe to Mahuta, 19 December 1994: both RC1, Correspondence Vol 37, December 1994, Box 15, W-T archives.

${ }^{345}$ Mahuta to Henare, 19 December 1994, RC1, Correspondence Vol 37, December 1994, Box 15, W-T archives

${ }^{346}$ Henare to Mahuta, 19 December 1994; Rowe to Mahuta, 19 December 1994: both RC1, Correspondence Vol 37, December 1994, Box 15, W-T archives.

${ }^{347}$ Diamond, A Fire in the Belly! Māori Leaders Speak, 134.
} 
Mahuta hoped that Henare would be able to travel to Hopuhopu to stay overnight and be present at Turangawaewae on the $21^{\text {st }}$ of December for the meeting planned with Graham. ${ }^{348}$

\section{Waikato-Tainui's Treaty settlement and the reactions from Māoridom}

Waikato-Tainui's Heads of Agreement set out the major features of the settlement. The overall quantum of $\$ 170$ million consisted of land-banked properties, some Crown properties that were leased back at market rates to government departments, Te Rapa airbase (Hopuhopu was transferred at zero value to the overall quantum), and cash with which to purchase land. Department of Conservation land was specifically excluded from the settlement. The Heads of Agreement contained the Right of First Refusal (RFR), which provided Waikato-Tainui with the right to be the first to purchase Crown properties as they became available for disposal or privatisation. Waikato-Tainui negotiators also negotiated interest payments that added up to approximately $\$ 20$ million. Interest was paid to WaikatoTainui from the date their Heads of Agreement was signed to the date their full quantum was paid at a rate of $8.8716 \%$ approximately four years later. ${ }^{349}$

With the support and authorisation of Cabinet, Graham travelled to Turangawaewae Marae to present the Crown's offer in late December 1994. He advised those present that although it was not as much as they had wanted, it was still the best deal possible that any government had ever offered and believed that they should approve it. He then opened the floor for questions. Most of the questions centered on the need for more compensation, the rights of hapu and the perception that Treaty rights would be negated by the settlement. Many questions came from those opposed to the settlement, mostly from Ngāti Wairere and Ngāti

\footnotetext{
${ }^{348}$ Mahuta to Henare, 19 December 1994, RC1, Correspondence Vol 37, December 1994, Box 15, W-T archives.

${ }^{349}$ A fax from Solomon to ToWPU official 4 regarding the interest: "Mr Mahuta would like you to consider interest accruing from the date the Heads of Agreement are signed. Enjoy your day - Shane." Solomon to ToWPU official 4, 18 December 1994, TC30 Vol. 42, OTS archive; Waikato-Tainui Raupatu Deed of Settlement, 22 May 1995, Section 11.
} 
Whawhakia, but there were also a few appeals from the crowd for calm and a defence of Mahuta. Those present at the Turangawaewae hui voted individually 252 to 84 in support of the Heads of Agreement. 51 out of 56 marae representatives and 31 of 33 hapū were supportive. $^{350}$

In the end Mahuta and Queen Te Atairangikaahu had advised their people to accept the offer. Even then, the settlement nearly fell through at the final hour late in December 1994. Due to a miscommunication the Crown was informed by a Waikato-Tainui advisor that Waikato-Tainui would reject the offer, when Mahuta instructed his advisors to accept the offer. The agreement was only salvaged because of the positive personal relationship that had been developed between Graham’s officials and Mahuta’s main advisors. Constructive relationships between officials and advisors could be very beneficial to ensure successful negotiations. This was emblematic of the fact that above all it was personal relationships that were the key to successful negotiations. ${ }^{351}$ Michael Belgrave has commented that it was the personalities of Mahuta, Graham and O’Regan that drove their negotiations but the relationships between the officials and advisors below the principals were just as important. $^{352}$

On 21 December 1994 the negotiations went into the evening as Waikato-Tainui negotiators sought to have the relativity clause included in the agreement. Graham and Mahuta went for a walk around the oval at the Hopuhopu Sports Facility. Both Denese Henare and the lead Treasury official wanted to accompany their respective leaders, but their requests were rejected. Mahuta and Graham would finalise the deal alone with a pair of

\footnotetext{
350 “Turangawaewae hui voting results,” 21 December 1994, TC30 Vol. 42, OTS archive; “Turangawaewae hui,” 21 December 1994, RC1, Correspondence Vol 37, December 1994, Box 15, W-T archives.

“Turangawaewae hui,” 21 December 1994, RC December - August 1994, Box 32, W-T archives; John Te Maru, "file note", 1 January 1995, RC1, Correspondence Vol 38, Jan - Feb 1995, Box 16, W-T archives.

${ }^{351}$ Interview with Shane Solomon, 28 May 2011, Interview with ToWPU Official 4, 24 May 2011.

${ }^{352}$ Michael Belgrave, Historical Frictions, 332.
} 
cigars. ${ }^{353}$ Graham telephoned Prime Minister Jim Bolger to confirm that he could include the relativity mechanism that Cabinet had not yet approved and Bolger confirmed that it could be included. ${ }^{354}$ The relativity clause effectively cemented the agreement and provided WaikatoTainui with a powerful defence within their community against charges of finality; but this served to alienate some Māori groups outside of the rohe. Finally, the relativity clause was also included: “[T]he redress represents $17 \%$ of the value of the redress set aside by the Government for historical claims under the Treaty of Waitangi.” While the Heads of Agreement set out the general outline of the settlement, the specific details remained to be negotiated for the final Deed of Settlement such as the methodology for the RFR and the relativity clause. In addition, the two parties also still needed to determine the market value of Crown land that was set to be transferred and negotiate the leases that would follow between Waikato-Tainui and government departments. ${ }^{355}$ Mahuta invited Graham and his team for a trip up to Taupiri Mountain that night to share a moment of reflection following the intense and protracted negotiations. ${ }^{356}$

The media reported on both the celebration of supporters of the settlement as well as the protests of opponents. Although Mahuta and Graham were generally the lead items on the news, Waikato-Tainui critic Eva Rickard was featured in the newspapers and on TV1 News

\footnotetext{
${ }^{353}$ Interview with Sir Douglas Graham, 23 May 2011; Interview with ToWPU official 4, 24 May 2011.

${ }^{354}$ Diamond, A Fire in the Belly, 138; Bolger, A View from the Top, 178.

355 "Waikato-Tainui Heads of Agreement," 21 December 1994, TC30 Vol 42, OTS archive. These were being proposed because much of the land that was set to be transferred to Waikato-Tainui was education lands or research stations which had previously had such agreements with the government. At the most basic level the negotiations regarding the valuation framework and structure of the leases were an extension of Waikato attempting to negotiate more valuable frameworks while the Crown tried to maximize its own benefits from the proposed system. Leases had to be negotiated differently with the myriad different departments and the general valuation framework would have a large influence on how the Waikato quantum was spent overall. This was very significant to the whole implementation side of the treaty settlement endeavour. The Crown wanted a process that minimised its contingent liabilities, that is the improvements that were situated on Crown land. Waikato on the other hand needed a methodology which based valuation on income potential. Waikato wanted to ensure that there were no perpetual leases negotiated within the confines of its settlement: "Meeting between Crown and Waikato negotiators," 4 April 1995, RC1, Correspondence Vol 39, Mar - Apr 1995, Box 17, W-T archives; John Te Maru, “file note," 5 April 1995, RC1, Correspondence Mar - Apr 1995, (SS) Box 35, W-T archives.

${ }^{356}$ Graham, Trick or Treaty?, 76.
} 
on the night of 22 December 1994. TV1 News introduced the news item as the "Treaty of Waikato, that's the historic document to settle the biggest Māori land claim under the Treaty of Waitangi.” While the Waikato Times' editors were supportive of Waikato-Tainui and the Crown for signing the settlement the Evening Post cynically titled their editorial on the signing of the Heads of Agreement: “Full and final settlement?” Prime Minister Jim Bolger, a ToWPU official and Crown official Shane Jones participated in interviews on the radio and extolled the great courage that Mahuta, Te Arikinui, and the Waikato-Tainui community showed in settling the raupatu land grievance. Mahuta was quoted in the Waikato Times at the end of the year stating that the deal was for "Waikato Māori. It was our land that was taken and the Government should not use it as a precedent.” This point was later reflected in the final Deed of Settlement. One of the Crown's acknowledgments stated "that the decision of Waikato in relation to the Settlement is a decision that Waikato take for themselves alone and does not purport to affect the position of other tribes.”357 John Te Maru defended the settlement but refused to state that it was an acknowledgment of the fiscal envelope. Waikato-Tainui's negotiating position was that as land was taken so it should be returned and that is what had happened in their eyes. ${ }^{358}$ Their settlement had resulted in the transfer of land to Waikato-Tainui, but from their point of view they had been forced into the Crown's proposals for settlement.

On 29 January 1995 a pan-Māori hui was held in Turangi at the behest of Sir Hepi Te Heu Heu. The hui rejected the Crown's proposals for settlement in their entirety.

\footnotetext{
${ }^{357}$ Waikato-Tainui Deed of Settlement, 22 May 1995, 5.

358 TV1 6pm News, 22 December 1994, TVNZ Avalon archives; Paul Bensemann, "Courage of making a start", Waikato Times, 22 December 1994; Richard Knight, "Waikato's land struggle over", Waikato Times, 22 December 1994; Reuben Wharawhara, "'No mandate' on Waikato deal", 23 December 1994, New Zealand Herald; "'Full and final' settlement?", 23 December 1994, The Evening Post; "Move to scrap deal", 23 December 1994, Waikato Times; "Waikato - still writing itself a place in history" 23 December 1994, Waikato Times; Richard Knight, "Settlement deal draws flak from Māori factions", 29 December 1994, Waikato Times; Richard Knight, "Mission impossible's new dawn" 30 December 1994, Waikato Times; Radio sources, check TC30 Vol. 42. Eddie Durie to Mahuta \& Durie to Graham, 22 December 1994, TC30 Vol. 42, OTS archive; RC1, Correspondence Vol 37, December 1994, Box 15, W-T archives.
} 
Representatives of iwi around the country spoke against the fiscal envelope but most of the other parts of the proposals were not discussed even though the meeting rejected all aspects of them. The opinions on Waikato-Tainui's signing of a heads of agreement with the Crown were far more divided. Waikato-Tainui hapū that opposed Mahuta and the TMTBrepresented by Eva Rickard, Gareth Seymour-Ormsby and Ngapare Hopa—spoke against Waikato-Tainui's settlement and condemned the TMTB's consultative process as undemocratic. Seymour-Ormsby put forward a resolution at the hui to "condemn the TMTB's acceptance of the fiscal envelope.” The Chairperson of the hui, Whanganui eader Archie Taiaroa, countered with the motion that it would not be tabled because the issue was not the “business of the hui.” “This was met by cries of 'yes it is!'...however the resolution proceeded no further.” A representative of the TMTB, Tui Adams, specifically read out the TMTB's rejection of the fiscal envelope policy at the Turangi hui. The junior legal advisor for Waikato-Tainui, Shane Solomon, felt that Kuru Waaka of the Te Arawa Māori Trust Board brought what Solomon described as a "calming influence to the hui" by stating that it was up to each iwi to decide for themselves how they would negotiate with the Crown. Waaka pleaded to those in attendance to understand that Waikato-Tainui had not made the decision to settle lightly and that the conditions for Waikato-Tainui were different than all other groups in the country. Waaka stated that it was about "considering the best interests of the tribe for the present and seeking solutions for the future.” The hui then concluded with all present endorsing Sir Hepi Te Heu Heu's motion to reject the Crown's proposals. ${ }^{359}$ The mood of the Turangi hui reflected the same tone as the Crown's fiscal envelope hui that occurred around the country in the first half of 1995—-fronted mainly by TPK staff led by then CEO Wira Gardiner. The fiscal envelope hui around the country were very hostile to the

\footnotetext{
${ }^{359}$ Solomon, “Turangi hui”, RC1, Correspondence Vol 38, Jan - Feb 1995, Box 16, W-T archives, 6-7.
} 
Crown, and rejected the Crown's proposals for settlement in at times forceful and dramatic ways. $^{360}$

Waikato-Tainui's alleged association with the fiscal envelope remained a pressing issue and was discussed at a meeting of Waikato-Tainui negotiators and their advisors in January 1995. Mahuta was concerned that Waikato-Tainui were being used by the Crown to support their proposal for the fiscal envelope. The Crown claimed that Waikato-Tainui had acquiesced to the policy despite the iwi’s public opposition. Graham had stated on Radio Pacific that Waikato-Tainui had accepted the fiscal cap. Waikato-Tainui negotiators travelled around the Waikato-Tainui rohe to explain the settlement to the dozens of marae affiliated with the TMTB. In addition to the Waikato rohe the negotiators also travelled to Auckland, Hastings, Wellington, Parihaka, Papakura/Otara, Maketū and Christchurch to explain the settlement to those Waikato-Tainui beneficiaries living outside of the rohe. In the end there were at least a hundred hui from October 1994 to May 1995. Most of the Waikato-Tainui negotiators' time was spent trying to separate their agreement with the Crown from the Crown’s fiscal envelope proposals. ${ }^{361}$

In early February 1995 the Institute for NZ Studies held a conference in Wellington analysing Treaty claims entitled "Unfinished Business" at which a series of Crown Ministers, Labour politicians, academics, lawyers, claimants and prominent Māori figures (including Mahuta) presented their views on the Treaty settlement process. ${ }^{362}$ Shane Solomon reported that most of the students attending felt that Waikato-Tainui had "sold them out" and that Waikato-Tainui had acquiesced to the fiscal cap. There was a misconception that Waikato-

\footnotetext{
${ }^{360}$ Wira Gardiner, Return to Sender: What really happened at the fiscal envelope hui (Auckland: Reed Books, 1996).

361 ToWPU official 4, "Meeting between B teams,” 30 January 1995, 12-030-00-35, OTS archive; Solomon, “Meeting between B teams," 30 January 1995; RC1, Correspondence, Jan - Feb (SS) 1995, Box 34, W-T archives, 2; Solomon, "Meeting of Waikato negotiators," 8 February 1995, RC1, Correspondence Vol 38, Jan Feb 1995, Box 16, W-T archives.

${ }^{362}$ Geoff McLay (ed.), Treaty Settlements: The Unfinished Business (Wellington: Victoria University Press, 1995)
} 
Tainui approved of the fiscal envelope. Solomon repeatedly pointed those who questioned Waikato-Tainui to the October 1994 issue of Kaa Hiwa Raa which outlined the firm opposition of Waikato-Tainui to the fiscal envelope policy. ${ }^{363}$

While Waikato-Tainui struggled to separate its own settlement from the fiscal cap, the Crown debated the effect that the settlement might have on its own universally rejected policy. Before meeting with Waikato-Tainui negotiators in early March 1995, internally Crown officials debated whether the signing of the settlement would signal to other iwi that Waikato-Tainui had accepted the fiscal envelope. Waikato-Tainui legal advisor Denese Henare pressed for the final Deed of Settlement to contain a more explicit rejection of the fiscal envelope. ${ }^{364}$ CLO officials sought to minimise the importance of the fiscal envelope policy to Waikato-Tainui negotiators. In a draft of meeting minutes CLO officials sought to remove the discussions of Waikato-Tainui's difficulties separating the fiscal envelope from the settlement. ${ }^{365}$ Late in the negotiations a teleconference between Waikato-Tainui and Crown advisors produced an agreement to explicitly state that Waikato had rejected the fiscal envelope policy. ${ }^{366}$

Mahuta accepted that the Crown could not state that Waikato-Tainui's claim was the largest, but that the relativity clause would preserve that fact nonetheless. He believed that the relativity clause would challenge the Crown's fiscal limits:

My view is that the relativity clause is of the utmost importance...[because] it allows the settlement not to be full and final and preserves our position...being the first to settle must mean we are taking a risk in fixing the value of our settlement, without the luxury of benchmarking against what other Tribes will receive. This must be the trade off for the Crown in activating the process. If anything in these negotiations, the relativity guarantee is the most significant term to secure. It destroys both the cap

\footnotetext{
363 Solomon, "Wellington Unfinished business conference," 9-10 February 1995, RC1, Correspondence, Jan Feb (SS) 1995, Box 34, W-T archives.

364 “Crown B Team meeting,” 2 March 1995, 12-030-00-35, OTS archive.

365 "Waikato and Crown B Teams meeting," 2 March 1995, 12-030-00-35, OTS archive; CLO official 4 to ToWPU official 4, 10 March 1995, 12-030-00-35, OTS archive.

366 “Telephone Conference: 11:30am, Advisers - Crown and Waikato,” 18 May 1995, RC1, Correspondence May 1995 Vol 40, Box 18, W-T archives.
} 
concept (for ourselves and other tribes) and provides a mechanism to re-visit the settlement in the future.

ToWPU officials and Graham had both indicated to Solomon that their claim was the largest but that it could not be explicitly stated. ${ }^{367}$

In correspondence with his advisors Mahuta stated that it was critical for WaikatoTainui that the relativity clause be included in the Deed of Settlement. Mahuta believed that the Crown was trying to back out of the arrangement and stressed to his advisors that they should press the Crown on the issue:

I have negotiated with the Crown on a 'land for land' basis. The Crown wanted to set the value of redress for this claim and insisted that the clause setting out the value of redress be quantified as a percentage of all historical claims. It was their policy at the time to put a figure on all of the Treaty claims registered with the Crown (the fiscal envelope policy). The Crown seems to be changing the rules again now that their policy has been rejected at recent hui with iwi. It has always been my understanding that the Crown has considered that the Waikato raupatu claim would result in the largest settlement. ${ }^{368}$

Once the Crown had imposed the fiscal cap, and began setting out its own views on how much the Waikato-Tainui settlement would represent from the total amount available for all settlements, Waikato-Tainui had developed the idea of the relativity clause. It now fought to retain its benefits within the parameters set by the Crown. One of Waikato-Tainui's financial advisors commented that the Crown was not legally bound to provide the relativity clause. Indeed at the same time internally the Crown was debating the relativity clause as the government sought to attempt to predict its repercussions on negotiations with other claimants. $^{369}$

\footnotetext{
${ }^{367}$ Solomon to Te Maru, 3 May 1995, RC1, Correspondence May 1995, (SS) Box 38, W-T archives, 3-4. ${ }^{368}$ Mahuta to the Advisors, 4 May 1995, RC1, Correspondence May 1995 Vol 40, Box 18, W-T archives. ${ }^{369}$ Tom Moke to Mahuta, 6 May 1995, RC1, Correspondence May 1995 Vol 40, Box 18, W-T archives; CSC (95) 66, NE 10-030-00-02 pt.2, OTS archive; CSC (95) 67 \& CSC (95) M 15/7, AAKW W5105 781223 Waikato: 1995 Pt.3, Archives NZ.
} 
Crown officials and Waikato advisors met in early May 1995 under a considerable amount of pressure because Waikato-Tainui negotiators wanted the signing of the Deed of Settlement to coincide with the annual coronation ceremony for Queen Te Atairangikaahu on 22 May. ${ }^{370}$ ToWPU stated in a memo to Waikato-Tainui legal advisor Gerard Brown in May 1995 that the relativity clause was facing opposition from within the Crown, especially the CLO and Treasury, because it would leave open issues for which the Crown desired finality. ${ }^{371}$ The Crown also denied that they had ever stated that the Waikato-Tainui claim was the largest. Solomon pointed out that he had diary notes which specifically stated that the Crown commented that in fact it was. Waikato-Tainui negotiators pointed out to their Crown counterparts that the relativity clause was incredibly important to the wider Waikato-Tainui community and that the signing of the settlement hinged on its inclusion. ${ }^{372}$ Despite the Crown's apprehensions Waikato-Tainui was able to preserve its relativity clause and provide a strong argument for its own people that the settlement was not full and final.

By the end of July 1995 the Crown had decided under Waikato-Tainui pressure that the definition of total redress amount in the Waikato-Tainui relativity clause would exclude gifts less than 5\% of the total \$170 million quantum (such as the Hopuhopu Army Base valued at approximately $\$ 4$ million), the Crown's negotiating and implementation costs, legislative changes affecting property rights, and the interest that would accrue on the settlement from the signing of the Heads of Agreement until the full quantum of $\$ 170$ million was paid. ${ }^{373}$ While Waikato-Tainui was constrained by the fiscal envelope policy, there were

\footnotetext{
${ }^{370}$ John Te Maru, "Meeting of B Team,” 18 April 1995, RC Vol 39, Mar - Apr 1995, Box 17; McCan, Whatiwhatihoe: A History of the Raupatu Claim, 316; Pei Te Hurunui Jones, "Māori Kings" in The Mãori people in the nineteen-sixties (ed.) Erik Schwimmer (Auckland: Hurst, 1968).

${ }^{371}$ Gerard Brown to CLO contractor, 1 May 1995 \& O’Regan to Brown, 2 May 1995, RC1, Correspondence May 1995, (SS) Box 38, W-T archives; ToWPU official 4 to Brown, 3 May 1995, RC1, Correspondence May 1995 Vol 40 Box 18, W-T archives.

${ }^{372}$ Solomon, "Meeting of Advisers, Rudd Watt and Stone," 5 May 1995 \& OTS official 1 to Mahuta, 5 May 1995, RC1, Correspondence May 1995 Vol 40, Box 18, W-T archives.

${ }^{373}$ CSC (95) 121; CSC (95) M 27/8, AAKW W5105 7812 22, Archives NZ.
} 
financial aspects of their settlement that were not included in their settlement quantum. As a result Waikato-Tainui’s settlement was nominally valued at \$170 million but it was worth much more. Those exceptions to the fiscal envelope policy benefitted Waikato-Tainui by providing them with a larger quantum.

\section{Part III: Ngāi Tahu's Treaty settlement}

The litigation phase of Ngāi Tahu's negotiations: 1995

As Waikato-Tainui proceeded to sign its Heads of Agreement in late December 1994, Ngāi Tahu's negotiations completely broke down. The beginning of the breakdown of the negotiations can be pinpointed to early August 1994 when the Crown asked that their monthly meetings be delayed until the announcement of the Crown's new Treaty settlement policy at the end of the year. Ngāi Tahu had become increasingly agitated with the lack of progress occurring at the monthly meetings but they perceived that the continuation of discussion was still key to the negotiation of a final settlement. The negotiations officially broke down in December 1994. ${ }^{374}$ Ngāi Tahu would state that the Crown had unilaterally cut off the negotiations during the period of the breakdown from the end of 1994 until the start of 1996. ${ }^{375}$

In November 1994 an interim settlement was offered to Ngāi Tahu, which the negotiators took back to the iwi and it was rejected. It proposed that Ngāi Tahu receive freehold title to Rarotoka Island but with the imposition of a marginal strip ${ }^{376}$, Tutaepatu

\footnotetext{
${ }^{374}$ Price, The Politics of modern history-making: the 1990s negotiations of the Ngāi Tahu tribe with the Crown to achieve a Treaty of Waitangi claims settlement, Macmillan Brown Series, 1994; Graham, Trick or Treaty?, 79-84.

${ }^{375}$ O'Regan to Graham, 10 February 1995, Vhi 17(f) TRONT archive; Steve Evans, "Crown forced Ngāi Tahu to take legal steps,” The Independent, 23 June 1995.

${ }^{376}$ A marginal strip is an area of land, usually 20 metres, which extend along and abut the landward margins of parts of the foreshore and the beds of other water bodies that meet certain minimum size requirements. The strips are created when the Crown disposes of land. http://www.linz.govt.nz/survey-titles/cadastralsurveying/publications/marginal-strips
} 
Lagoon, and \$10 million worth of land-banked properties in exchange for a revised land-bank system. ${ }^{377}$ Ngāi Tahu was certainly not averse to the idea of an interim settlement, long advocating that a series of interim settlements would be better than the idea of a full and final settlement, but this offer was less than adequate from the point of view of Ngāi Tahu negotiators. $^{378}$

ToWPU and TPK officials had struggled to convince Treasury officials that the terms of the interim offer were beneficial to the Crown. ToWPU and TPK officials stressed that all of Treasury's problems with regard to the conditions of acceptance of the "on account" settlement were addressed in the interim offer. These problems related mainly to the condition that Ngāi Tahu waive all other forms of redress such as approaching the Waitangi Tribunal or Court of Appeal. In the end Treasury recommended that Graham not propose the "on account settlement” because it would not provide the finality or certainty which the Crown sought as one of its objectives. ToWPU and TPK officials stressed that in the midst of stalled negotiations Crown negotiators had a chance to show that the extended negotiations had not been conducted without some sort of tangible result. Cabinet approved the "on account” settlement and merely acknowledged Treasury’s reservations, which was a rare event at that time. ${ }^{379}$

In the end neither Treasury nor Ngāi Tahu approved the “on account” settlement offer. While Treasury declined to approve the "on account" offer because of the lack of "certainty" which it would provide the Crown, Ngāi Tahu refused the offer because of the

\footnotetext{
${ }^{377}$ For all other iwi with land-banks, the properties contained in the land-bank would have to be used in any Treaty settlement. Ngāi Tahu was able to purchase lands in the land-bank with their own funding and on-sell for a profit. Ngāi Tahu was then allowed to add additional lands to the land-bank. This was only tenable in the large rohe of Ngāi Tahu that consists of most of the South Island.

${ }^{378}$ Pete Barnao, "Ngāi Tahu settlement 'far away'," Otago Daily Times, 26 October 1994; Graham to O’Regan, 2 November 1994, C-27-2-02 Vol. 3, OTS archive; O’Regan to Graham, 20 December 1994, C-27-2-02 Vol. 3, OTS archive.

379 "Ngāi Tahu negotiations work strategy and programme Cabinet Select Committee Memorandum," 25 October 1994, C27-1-02 Vol. 2, OTS archive.
} 
lack of “certainty” which it would provide Ngāi Tahu. Ngāi Tahu’s reservations related to the limited offer which had neglected issues such as the importance of Ngāi Tahu's unique landbanking system ${ }^{380}$, Whenua Hou and the Crown Titi Islands, and had not provided enough concessions on pounamu, Rarotoka Island and title to the Arahura Valley. Whenua Hou and the Crown Titi Islands, Rarotoka Island and title to the Arahura Valley were shortcomings related to the Department of Conservation's (DoC) own reservations rather than Treasury's concerns, and were reflective of the distinct challenges that existed within the Crown's own policy development process. ${ }^{381}$ DoC would begin to play a prominent role in Ngāi Tahu's negotiations from 1994 onwards, taking on the role often played by Treasury as key internal government critic of the Treaty settlement process.

Throughout 1995 Ngāi Tahu engaged in litigation against the Crown with at one point twelve concurrent lawsuits in place. ${ }^{382}$ Returning to the Courts had always remained open to Ngāi Tahu as an option. Throughout the early negotiating period Ngāi Tahu negotiators had maintained the threat, which became more apparent as the negotiations progressed towards the breakdown in $1994 .{ }^{383}$ The Courts had been the site of boundary disputes between Ngāi Tahu and Rangitane and other northern South Island iwi and hapū, and also a series of lawsuits involving the Treaty of Waitangi Fisheries Commission. By the end of 1994, Ngāi Tahu had turned the focus of litigation towards the Crown: the Attorney-General, Landcorp, the Department of Conservation and Coalcorp.

\footnotetext{
${ }^{380}$ Under which Ngāi Tahu was able to purchase lands with its own funds and on-sell privately at a profit, and then add further surplus Crown properties into their land-bank.

${ }^{381}$ O’Regan to Graham, 20 December 1994, C-27-2-02 Vol. 3.

${ }^{382}$ Chris Finlayson, "Ngāi Tahu negotiations" in Margaret Clark’s The Bolger Years: 1990-1997 (Wellington: Dunmore Publishing, 2008), 181-195; OTS Director to Graham, 30 March 1995, NE-10-027-00-02 Pt.1, OTS archive.

${ }^{383}$ Davidson and O’Regan, “Meeting between Nick Davidson, Tipene O’Regan Rob Laking and Doug Graham,” 2 June 1994, TRONT archive.
} 
The first Court action had been the commercial rights which Ngāi Tahu believed it should have priority over the whales around the Kaikoura area. The Crown also had given an undertaking that it would not issue any more pounamu licences pending the transfer of ownership of pounamu to Ngāi Tahu, but as the negotiations dragged on this undertaking did not provide enough comfort for Ngāi Tahu. In early 1995 proceedings were filed against the Crown to restrain it from issuing these licences because Ngāi Tahu felt that the Crown had not honoured its undertaking. ${ }^{384}$ Although Ngāi Tahu were not successful in all areas of litigation, they received favourable judgments in both the pounamu and whales cases against the Crown, and were able in the end to force the Crown back to the negotiating table.

Specific government assets such as Landcorp, Coalcorp and SOE properties were one focus of Ngāi Tahu's lawsuits. Disagreements over Landcorp centred on the number of Landcorp farming properties Ngāi Tahu would be allowed to visit to decide on their suitability for inclusion in their final settlement. Ngāi Tahu wanted the opportunity to visit all Landcorp farming properties in their part of the South Island. The Crown stressed that visiting five farms would be more 'reasonable' in their eyes. Ngāi Tahu believed it should have a larger quantum than the Crown was proposing and as a result wanted to view all the available farms owned by Landcorp. After significant lobbying some information was shared by Crown officials regarding stock numbers, but valuations were not forthcoming since Treasury claimed that it was sensitive commercial information. Like many issues facing Ngāi Tahu and the Crown the issue of quantum was at the core of the problem. Proceedings were also filed against the Crown in relation to the Coal Export Project being planned on the West Coast of the South Island. Coalcorp was developing coal mines focused specifically on the export market, and Ngāi Tahu sought to have their interests protected in such a project. In

\footnotetext{
384 "Meeting of Te Runanganui o Tahu," 29 January 1994, NT140 M14 @, MB archives; Minister of Justice to Cabinet Strategy Committee, 19 July 1995, "Ngāi Tahu: Overview of Ngāi Tahu Claims and Legal/Redress Proceedings,” NE-12-027-00-2 Vol. 1, OTS archive.
} 
June 1995 Ngāi Tahu amended their claim to the Waitangi Tribunal in which they sought binding recommendations for the return of all SOE properties in the Ngāi Tahu rohe. ${ }^{385}$ They had also sought access to forestry assets held by the Crown Forestry Rental Trust. ${ }^{386}$ There was a significant fear from within the Crown that the Tribunal would use its binding powers to return Crown Forests in the Ngāi Tahu rohe to Ngāi Tahu with a very significant financial award made possible under the terms of the Crown Forest Assets Act.

The option for Ngāi Tahu to take their case back to the Waitangi Tribunal always remained a possibility, and it was occasionally threatened in the first year of the negotiations in 1991-1992 by Ngāi Tahu to stress to the Crown its own leverage. This threat was finally carried out in late 1994 and a meeting with the Tribunal was planned for early 1995. It was originally meant to be presided over by Judge Ashley McHugh, who had presided in the original inquiry and was seen by many as sympathetic to Ngāi Tahu because of his role as Presiding Officer of the Ngāi Tahu Waitangi Tribunal inquiry. At the last second the Chairperson of the Waitangi Tribunal, Chief Judge Eddie Durie, replaced McHugh. Citing a lack of funding and time, Durie refused to hear the Ngāi Tahu case. Ngāi Tahu subsequently filed proceedings against Durie for refusing to hear their urgent inquiry, and against the Attorney-General for not providing enough funding for the Waitangi Tribunal. ${ }^{387}$

Ngāi Tahu clearly presented a very difficult decision for Chief Judge Durie. Ngāi Tahu had been one of the first major hearings of the post-1985 era and four separate reports had been published between 1991 and 1995 regarding the Ngāi Tahu claim. The backlog of other claims was quite substantial and Durie considered that Ngāi Tahu had already been

\footnotetext{
${ }^{385}$ Under the Treaty of Waitangi (State Enterprises) Act 1988 State Owned Enterprises properties were marked with a protection memorial that ensured that if a claim was well-founded then the Tribunal could make a binding order for the mandatory resumption of the property for transferral to the settling Māori group.

${ }^{386}$ Minister of Justice to Cabinet Strategy Committee, 19 July 1995, "Ngāi Tahu: Overview of Ngāi TahuClaims and Legal/Redress Proceedings,” NE-12-027-00-2 Vol. 1, OTS archive.

${ }^{387}$ Steve Evans, "Ngāi Tahu to file in High Court over South Island forestry claim," The Independent, 31 March 1995; Durie files, Volumes 1-3, TP-02-027-00-01, OTS archive.
} 
given a large amount of the Tribunal's attention and resources. Nevertheless the option for Ngāi Tahu to return to the Tribunal had always existed, and from the point of view of the majority of Ngāi Tahu beneficiaries, not only (now) Sir Tipene O’Regan, returning to the Tribunal was clearly the best course of action at that time. ${ }^{388}$ The negotiations had come to a complete standstill. Coupled with the series of lawsuits in the High Court a return to the Tribunal was a natural extension of the Ngāi Tahu strategy.

The litigation strategy employed by the Ngāi Tahu negotiators was not universally accepted amongst the diverse Ngāi Tahu community. Tensions with the negotiating group largely simmered during the litigation phase but after litigation had stretched on for a year Ngāi Tahu individual Richard Parata voiced his highly critical disapproval of the tactics of continued litigation. Parata was never a member of the negotiating team but like all other members of Ngāi Tahu he could communicate with negotiators. Parata stressed that the Privy Council and High Court would certainly decide on the basis of precedent. As WaikatoTainui’s settlement was nearly finalised, $\$ 170$ million would be the realistic precedent. Amongst many critical comments, he thought that the Crown did not so much break off negotiations as was forced to.

My opinion is that Ngāi Tahu may have misinterpreted the break off of negotiations with the Crown. Much weight has been put on the mischievous intent of the Crown rather than they were out of their depth and grossly inefficient. The Crown broke off negotiations because they could not answer all the complex issues presented by Ngāi Tahu. They needed to go to ground. As it turns out they made a mess of things with the 'Fiscal Envelope'. The point I am making is that Ngāi Tahu have the opportunity to capitalise on this position. ie Ngāi Tahu were the guinea pigs. Incidentally there is in Crown circles a lot of sympathy for Ngāi Tahu's position.

Parata further pointed out that despite the series of judicial proceedings the Crown never cut off Ngāi Tahu's main source of funding, the unique land banking agreement with which they were able to purchase lands with their own funds. To Parata this was a vivid example of the

388 “Ngāi Tahu hui-a-tau,” 2-3 November 1994, NT 140 B(x)9, Box 53. 
measured response that the Crown made to Ngāi Tahu's aggressive litigation strategy but it was one that he believed would not last forever. While Parata's opinion was not accepted by all Ngāi Tahu negotiators, it would continue to gain traction. Rakiihia Tau Snr defended the legal action as necessary because he had no trust in the political process. Tau Snr believed that the courts would be the only forum under which justice could be obtained and thus the litigation needed to continue. ${ }^{389}$

After the precedent-setting nature of Waikato-Tainui's 1995 settlement began to become clear, Ngāi Tahu negotiators gradually accepted that they would have to maximise their gains within the limited fiscal parameters that they perceived had been set. ${ }^{390}$ By the start of 1996 intervention by Prime Minister Jim Bolger had succeeded in bringing the two sides together. Bolger had a positive relationship with O’Regan and since the relationship between Graham and O’Regan had effectively soured Bolger took command of the situation. Bolger would play a major role in recommencing the negotiations in 1996 and Department of Prime Minister and Cabinet (DPMC) officials played a prominent role through this period. ${ }^{391}$ O’Regan and other Ngāi Tahu negotiators expressed their fear of the negative pressure of two DPMC officials on the re-commencement of negotiations and their potentially troubling influence on Bolger especially. ${ }^{392}$ Once negotiations had recommenced the Crown negotiating team was led by an official who previously worked at TPK and the Treasury for a

\footnotetext{
${ }^{389}$ Richard Parata to Davidson \& Parata to O’Regan, 6 \& 17 October 1995, Vhi 51 (f), TRONT archive, 3; Rakiihia Tau Senior to Parata, 21 October 1995, Vhi 51 (f), TRONT archive, 2.

${ }^{390}$ Tipene O’Regan to Ngāi Tahu negotiators, "The Post Envelope Vacuum," 31 March 1995, MB archive; Wira Gardiner on Kim Hill’s radio show, 25 January 1996, NE-12-027-00-02 Vol. 1; Davidson to Ngāi Tahu Negotiating Group, 15 September 1995, Vhi 51 (f), TRONT archive; Richard Meade to Sid Ashton, Charles Crofts, Anake Goodall, 15 December 1995, Vhi 51 (g), TRONT archive, 1.

391 “Good Morning NZ with Geoff Robinson,” 4 August 1995, NT140 M4 (c), MB archive; O’Regan to DPMC official 2, 3 August 1995, NT140 M4 (d), MB archive, 2; Interview with Sir Tipene O’Regan, 4 May 2011. Bolger to O’Regan, 7 March 1996, NE-12-027-00-02 Vol. 2, OTS archive, 1; O’Regan, "Meeting with Bolger,” 7 March 1996, Vhi48 (u), TRONT archive.

392 O’Regan, “TOR MTG. WITH PM,” 17 March 1996, TRONT archive. Later the two would earn the dubious distinction of being referred to by a Ngāi Tahu advisor as "[John] Halderman and [John] Erhlichman", two of former American President Richard Nixon's closest and most notorious advisors. Richard Meade, "Impending Principals’ Meeting(s),” 9 June 1997, TRONT archive.
} 
number of years. She was joined by a CLO official, who had worked on Treaty and especially Ngāi Tahu related issues throughout the 1990s, and a Treasury official who would later become Director of OTS. While Sir Tipene O’Regan and Rakiihia Tau Snr remained the Ngāi Tahu principals and remained intimately involved in the negotiations, they left the minutiae of negotiation to Ngāi Tahu officials. Claims Manager Anake Goodall was joined by longtime legal advisor Nick Davidson, commercial advisor Richard Meade and NTMTB Secretary Sid Ashton.

\section{From recommencement of negotiations to Heads of Agreement, Ngāi Tahu’s negotiations: 1996}

In May 1996 Ngāi Tahu negotiator Sir Tipene O’Regan and Bolger met throughout the month trying to establish the parameters for the negotiations. A point of contention was the separation of Ngāi Tahu's land claim from mahinga kai and environmental issues, as the Crown had separated Waikato-Tainui's land claims from its river and harbour claims, but the Crown would not budge on the issue. Even the precedent of $\$ 170$ million was still not completely agreed upon. Ngāi Tahu had accepted the nominal figure of \$170 million but they desired it in 1994 dollars as Waikato had received its settlement. The Crown maintained that it would only provide Ngāi Tahu with a settlement in 1996 dollars. Ngāi Tahu also desired an on-account settlement as an expression of the Crown's goodwill. But because the Crown was focused on a final settlement the government was uninterested in an interim settlement of any kind that would contradict the Crown's stated desire and need for 'comprehensiveness'. 393

\footnotetext{
${ }^{393}$ C T Materials (14); Ashton, "Crown - Ngāi Tahu meeting of Principals Tuesday 28 May 1996," Vhi 51b (k), TRONT archive; Anake Goodall, "Note of a meeting held in the Prime Minister’s Office," 28 May 1996, Vhi 51b (k), TRONT archive.
} 
The on-account settlement only occurred after direct lobbying to Prime Minister Bolger by O’Regan. ${ }^{394}$

Only days after O’Regan lobbied Bolger for an interim settlement, Graham returned to Cabinet for the approval of a potential on-account settlement. It was approved. In internal memoranda O’Regan noted that there was little risk for Ngāi Tahu in recommencing the negotiations at that moment and thus it would be best for the tribe for negotiations to start again. In early June 1996 O’Regan received a letter from OTS that negotiations had officially recommenced. ${ }^{395}$ On 14 June 1996 an agreement on the on-account settlement had officially been reached. Ngāi Tahu would receive ownership of pounamu and Rarotoka Island (including its foreshore and seabed without a marginal strip), shared management of Tutaepatu Lagoon and \$10 million. While the contentof the on-account settlement was reported in the media there was still little public knowledge of what else the Crown might agree to. The Dominion reported: "The best clue so far on the state of the negotiations is perhaps the face of Ngāi Tahu's chief negotiator. 'I saw Tipene O'Regan on Lambton Quay today,' a Government treaty official said last week. 'I don't know how his talks are going, but he had a huge grin. I'd have to imagine they're going very well.'" ${ }^{396}$ One of the key factors to recommencing negotiations was an on-account settlement more favourable to Ngāi Tahu than what had been offered at the end of $1994 .^{397}$

\footnotetext{
394 Sir Tipene O’Regan, “Negotiating with Politicians,” in Margaret Clark’s The Bolger Years: 1990-1997 (Wellington: Dunmore Publishing, 2008), 174-180, 179-180; Bolger, A View from the top, 179-181.

395 O’Regan, “Recommencing negotiations,” 30 May 1996, Vhi 51b, TRONT archive; OTS official 2 to O’Regan, 4 June 1996, C T Materials (16), OTS archive.

396 "The Ngāi Tahu (sic) wait in the wings," The Dominion, 19 June 1996.

${ }^{397}$ C T Materials (14); Ashton, "Crown - Ngāi Tahu meeting of Principals Tuesday 28 May 1996," Vhi 51b (k), TRONT archive; Anake Goodall, "Note of a meeting held in the Prime Minister’s Office,” 28 May 1996, Vhi 51b (k), TRONT archive; O’Regan, “Recommencing negotiations,” 30 May 1996, Vhi 51b, TRONT archive; OTS official 2 to O’Regan, 4 June 1996, C T Materials (16), OTS archive; OTS official 2 to Bolger, 5 August 1996, NE-10-027-00-02 Pt.1, OTS archive; Anake Goodall, "File Note of meeting with Prime Minister," 6 August 1996, TRONT archive; Ashton, “Handwritten Notes,” 13, 15, 19, 20 August 1996, Vhi 52 (g), TRONT archive; Ashton, “memo”, 16 September 1996, find thing, TRONT archive, 2; Goodall to Doug Kidd,
} 
Ngāi Tahu had agreed before recommencing their negotiations that the inclusion of all their claims and a $\$ 170$ million quantum would be the baseline for negotiations. Nonetheless Ngāi Tahu continued to advocate for a settlement that would only cover their land-based claims, and a settlement larger than $\$ 170$ million. Ngāi Tahu also sought a relativity clause. The Crown understood that Ngāi Tahu would seek the relativity clause because of Ngāi Tahu's reservations of the full and final nature of such a fiscally limited settlement. In addition the relativity clause was necessary to appease the Ngāi Tahu constituency on the wider issue of finality. ${ }^{398}$ There was nonetheless opposition from the Crown to providing the relativity clause to Ngāi Tahu. As the negotiations were recommencing a Cabinet paper produced by OTS and Treasury stated that the risks of the relativity clause outweighed the benefits and officials advised against providing it. ${ }^{399}$ The positions for each side largely remained firm throughout August 1996 and there was little movement in the negotiations. The election was scheduled for 12 October 1996 and it began affecting the nature of the negotiations as the Crown (and Ngāi Tahu) were pressured to sign an agreement or wait until after the election. Treasury was in favour of waiting until after the election while OTS wanted negotiations to continue. ${ }^{400}$

While there were a series of issues that affected the flow of negotiations in September 1996, perhaps the most important issue was the purchase of Wigram airbase which, like Hopuhopu and Te Rapa, was about to be decommissioned. Ngāi Tahu had expressed an interest in the inclusion of Wigram Airbase in its settlement. ${ }^{401} \mathrm{O}$ 'Regan claimed that there was still considerable cynicism about the Crown's integrity and the transfer of Wigram would

19 September 1996, Vhi 52c (u), TRONT archive; OTS official 2 to DPMC official 2, 4 September 1996, NE10-027-00-02 Pt.1, OTS archive.

${ }^{398}$ OTS official 2 to Graham, 22 September 1996, NE-10-027-00-02 Pt.1, OTS archive.

399 "Ngāi Tahu: Redress Package,” 31 March 1996, NE-12-027-00-02 Vol. 3, OTS archive.

400 Treasury to ToWPU, 30 August 1996 \& CAB (96) M 37/15: NE-10-027-00-02 Pt. 1, OTS archive; TOWPU Memorandum to Graham, 3 September 1996 \& Graham to O’Regan, 25 September 1996: Chapman Tripp materials OTS archive.

401 "Meeting between Ngāi Tahu and Crown negotiators," 5 June 1996, Chapman Tripp materials, OTS archive. 
help reaffirm the positive relationship between the Crown and Ngāi Tahu. O'Regan explained in a letter to Finance Minister Bill Birch that the transfer of Wigram airbase needed to be done outside of the negotiations because if the process for transfer required legislation then it could be halted when "it is strained through the Parliamentary sieve." ${ }^{402}$ This was a reference to the Parliamentary delays associated with Ngāi Tahu's legal personality legislation. The Crown assured Ngāi Tahu that Wigram would be transferred as part of their settlement.

Graham sent O’Regan another Crown offer on 25 September 1996 and asked for a response by the $27^{\text {th }}$ of September-the pressure of the election was bearing its force on the negotiations. The quantum of $\$ 170$ million would be supplemented by a Deferred Selection Process (DSP), a mechanism which Ngāi Tahu negotiators had sought in addition to the Right of First Refusal that was provided in the Waikato-Tainui settlement. The DSP mechanism allowed the tribe to buy with its own money Crown assets from a defined 'pool' of assets, within twelve months of Settlement Legislation being passed. The Crown refused to include a relativity clause. ${ }^{403}$ The reaction from Ngāi Tahu negotiators varied somewhat. Rakiihia Tau Snr rejected Graham's offer because he claimed that there were “too many denials” of Ngāi Tahu positions. O’Regan agreed in many ways with Tau but contended that the shifting of the Crown's positions was still possible. This was confirmed by Anake Goodall who spoke with OTS the day after the offer was received. ${ }^{404}$

Ngāi Tahu remained adamant the relativity clause be included especially in light of their agreement to include all their claims. In internal memoranda Ngāi Tahu advisors stated that the relativity clause was "essential” adding that it "costs the Crown nothing if it sticks to the envelope (and if it doesn’t intend to stick to the envelope, why is the quantum so

\footnotetext{
${ }^{402}$ O’Regan to Bill Birch, 17 September 1996, Vhi 52c (p), TRONT archive.

${ }^{403}$ Graham to O’Regan, 25 September 1996: Chapman Tripp materials OTS archive.

${ }^{404}$ Rakiihia Tau Senior to Anake Goodall, 27 September 1996 \& O’Regan to Goodall, 27 September 1996: Vhi 52b (b), TRONT archive.
} 
low?)”405 Treasury believed that only Waikato-Tainui was entitled to the relativity clause because they were the first to settle. OTS officials understood the importance of the clause to Ngāi Tahu and attempted to counter Treasury rationales regarding the relativity clause. ${ }^{406}$ Ngāi Tahu sought a relativity clause that was identical to Waikato-Tainui’s 17\% but Crown officials countered that it should be proportionate to the size of their settlement to the overall quantum provided for all claims. ${ }^{407}$ Since Ngāi Tahu did not receive the settlement in 1994 dollars that it had wanted, the value of its settlement was only $16.1 \%$ of the overall quantum. In addition there were mathematical irregularities in the relativity clause provided to Waikato-Tainui and if the exact same clause had been provided to Ngāi Tahu, it would have been triggered by Ngāi Tahu before Waikato-Tainui. It was unclear from the sources consulted exactly how this would have occurred but officials were clearly concerned about the old relativity clause provided to Waikato-Tainui. ${ }^{408}$ Despite Treasury opposition Ngāi Tahu was successful and had the relativity clause included in the Agreement in Principle signed in October 1996 before the election. ${ }^{409}$ Like Waikato-Tainui, Ngāi Tahu could not have settled without the relativity clause.

Treasury argued against signing the Heads of Agreement and believed that there were too many major unresolved issues that required the mandate of a newly elected government. On 30 September 1996 Cabinet authorised Graham to make another offer to Ngāi Tahu against Treasury's advice. This did not mean that the settlement was guaranteed. The same Cabinet meeting also authorised Graham to make an offer to Whakatohea negotiators. The

\footnotetext{
405 Meade to Ashton and Davidson, 11 September 1996, Vhi 52c (r), TRONT archive.

406 “Outstanding Issues Requiring Resolution by Principals,”4 September 1996, NE-10-027-00-02 Pt.1, OTS archive.

${ }^{407}$ Meade to Ashton and Davidson, 11 September 1996, Vhi 52c ${ }^{\circledR}$, TRONT archive; ToWPU official 5 to Graham, 22 September 1996, NE-10-027-00-02 Pt.1, OTS archive.

408 “Outstanding Issues Requiring Resolution by Principals,"4 September 1996, NE-10-027-00-02 Pt.1, OTS archive.

${ }^{409}$ OTS, "Heads of Agreement between Ngāi Tahu and the Crown for a Settlement of all of Ngāi Tahu 's Historical Claims,” 7 October 1996, CT File, OTS archive.
} 
Crown's negotiations with Whakatohea reached an Agreement in Principle, the equivalent of a Heads of Agreement, but it was rejected by the Whakatohea people during the ratification process. ${ }^{410}$ The same day O’Regan received notification from Finance Minister Bill Birch that the Crown approved of Ngāi Tahu purchasing Wigram outside of the settlement negotiations. Ngāi Tahu had indicated throughout this negotiating period that the transfer of Wigram was a pre-condition for settlement and this goal had now been met. O’Regan seemed to be generally inclined towards settling but advisor Sid Ashton stressed caution, especially if the approval of co-negotiator Rakiihia Tau Snr had not been expressly given. In between the 1st and 5th of October Ngāi Tahu managed to add some major additions to the Crown offer. The Crown offered to pay interest on the unpaid sum from the Deed of Settlement until final payment, but the Ngāi Tahu negotiators convinced the Crown to pay interest from the date of the Heads of Agreement. The Crown also agreed to gift redress for the conservation aspects of the settlement and negotiations over specific sites of cultural significance such as the Crown Titi Islands, Rarotoka Island, the Arahura Valley, access to mahinga kai sites and ancillary claims — that is their monetary value would not be subtracted from the $\$ 170$ million quantum. Chapter 3 will investigate the negotiations regarding the Crown Titi Islands and the Arahura Valley. Perhaps most significantly in comparison to Waikato-Tainui, Ngāi Tahu was able to arrange to have one dedicated seat on the New Zealand Conservation Authority which Waikato-Tainui had sought but they had only received a dedicated seat on the Waikato Conservation Board. Ngāi Tahu negotiators had achieved what they believed to be "major

\footnotetext{
${ }^{410}$ CAB (96) M 37/15 \& CAB (96) M 37/22, NE-10-027-00-01 Pt. 1, OTS archive; Ranginui Walker, OpotikiMai-Tawhiti: Capital of Whakatohea (Auckland: Penguin, 2007); Paul Spoonley, Mata Toa: The Life and Times of Ranginui Walker (Auckland: Penguin, 2009).
} 
bolt-ons” in addition to the $\$ 170$ million quantum, RFR, interest payments and relativity clause that had been provided to Waikato-Tainui. ${ }^{411}$

On 5 October 1996 a Heads of Agreement was finally signed between Ngāi Tahu and the Crown. Graham commented to O’Regan at the signing of the deal: “I want to thank you for allowing me to share your suffering.” He joked that when negotiations began in earnest five years previously “Tipene had a full head of hair and I looked like Bill Birch.” He continued in the same vein that he had begun the Ngāi Tahu negotiations with reference to the innate "fairness" of New Zealanders. "This is the greatest country in the world. We have everything going for us and it will only be because of our own stupidity if we do not live in harmony, with respect and dignity.” The Dominion Post‘s Hugh Barlow commented that the Ngāi Tahu negotiations were marked by more complex factors and influences than the Waikato-Tainui negotiations because of the opposition of conservationists and the number of internal dissidents. The first point was correct because the claim to the river was excluded from the Waikato-Tainui negotiations but there certainly was substantial internal dissent against the WaikatoTainui settlement from academics such as Dr. Pare Hopa and Ngāti Wairere claimants camped out on disputed land well into 1996. The difference was that Ngāi Tahu dissidents Sandra Lee and Tirakatene-Sullivan held positions in the machinery of government and were able to more effectively influence the negotiation process. This was not the case for Waikato-Tainui dissenters. ${ }^{412}$

O’Regan commented at the signing that while the settlement was acceptable it could hardly be called fair, which did not impress Graham. Others such as ACT leader Richard

\footnotetext{
${ }^{411}$ Bill Birch to O’Regan, 30 September 1996, Vhi 53b (g), TRONT archive; Ashton, “Handwritten notes,” 30 September \& 2 October 1996, Vhi 52b (j), TRONT archive; Goodall to OTS official 2, 1 October 1996, Vhi 53b (k), TRONT archive; Graham, "Ngāi Tahu: Heads of Agreement," 5 October 1996, NE-10-027-00-01 Pt. 1, OTS archive.

${ }^{412}$ Hugh Barlow, "Freeing the future from grievance", 6 October 1996, The Dominion.
} 
Prebble commented to O’Regan “Well, you've out-negotiated the Crown again.” To O’Regan the question was no longer about justice, but about realistically achieving something for their grandchildren and the generations yet to be born. TV1 news was particularly supportive of Ngāi Tahu as it chose to headline with a three-minute story of which half was spent discussing the claim with Ngāi Tahu’s own historian, Harry Evison. The news story detailed the historical nature of the grievances - the duplicity of Crown agents such as Kemp and Mantell—and was generally supportive of Ngāi Tahu's claims despite their opposition and criticism of Māori claims in the past. News broadcasters noted that the approximately 630 acres of DoC land that was planned to be returned was from a total of 12 million acres of conservation land in the Ngāi Tahu region. On the Holmes Show, Doug Graham spoke to host Susan Wood about the settlement. Although she questioned the political motivations which the National government had to promote a settlement, it in fact could have just as easily hurt National as Dominion columnist Adam Gifford pointed out. ${ }^{413}$

OTS hoped to have a final agreement negotiated by March 1997, but the scope of the agreement was not yet apparent to Crown officials, and the negotiations would take an additional six months. ${ }^{414}$ Since the Crown's negotiations with Waikato specifically excluded any conservation issues there were a large number of new decisions to be made in terms conservation redress and the Crown and Ngāi Tahu had to work without any established precedents. Viewed in those terms, the final negotiation between the Heads of Agreement and the final agreement was completed in a very short time-span. As O’Regan pointed out in his 1993 Report to the NTMTB, Treaty settlement negotiations in Canada generally took 10-15

\footnotetext{
${ }^{413}$ Hugh Barlow, "Freeing the future from grievance", 6 October 1996, The Dominion; Adam Gifford, "Rush to settle claims unlikely to help Nats," The Dominion, 1 October 1996; TV1 News, 5 October 1996 \& Holmes Show, 6 October 1996, both: TVNZ archives, Avalon, Lower Hutt; Interview with Sir Douglas Graham, 22 May 2011.

${ }^{414}$ OTS official 3 to David Chisnall, 25 November 1996, Vhi 55c (i), TRONT archive; Bolger, A View from the Top, 179-181.
} 
years. Some of the Canadian Treaty settlements in the Arctic were completed in under ten years, but the Nisga’a settlement in British Columbia took nearly 25 years. ${ }^{415}$ Although Ngāi Tahu would have to follow the financial benchmark set by Waikato-Tainui, their settlement was far more comprehensive than Waikato-Tainui’s since it included claims to rivers, harbours and all other aspects of their claim as was noted above. ${ }^{416}$ Some of these conservation aspects will be discussed in Chapter 3. Ngāi Tahu's negotiations then were just as much precedent-setting as were Waikato-Tainui’s.

After the painstaking negotiations to a final settlement, led by Anake Goodall, there was opposition to the settlement from within Ngāi Tahu much as there had been for WaikatoTainui. Although Dr. Ngapare Hopa was not the original claimant who submitted the Waikato-Tainui claim, she was involved at the negotiating table for the first few years of negotiations in the late 1980s and early 1990s and Eva Rickard was a well-known Tainui advocate and they both headed the attempted injunction against the Waikato-Tainui settlement. Rakiihia Tau Snr was the actual original claimant and attempted to place an injunction on the signing of the settlement. Tau Snr's concern was primarily on behalf of his own hapū who believed it should receive its share of the settlement, rather than the entire settlement being controlled by the iwi. The lawsuit was eventually dropped but there remained the litigation led by the Waitaha opponents of the Ngāi Tahu negotiating team who disputed their mandate and the inclusion of Waitaha in the TRONT Act. There was also Ngati Apa, Rangitane and other Te Tau Ihu groups in general in the northern South Island, who sought to re-open a decision of the 1990 Māori Appellate Court regarding Ngāi Tahu’s

\footnotetext{
${ }^{415}$ Alex Rose, Spirit Dance at Meziadin: Chief Joseph Gosnell and the Nisga'a Treaty (Vancouver, 2000).

${ }^{416}$ Orange, The Illustrated History of the ToW, 223-226; Walker, Ka Whawhai Tonu Matou, 307-308; Sir Tipene O’Regan to Jim Bolger, 31 March 1996, NE-12-027-00-02 Vol. 3, 1-3; Sid Ashton, "Future Negotiations,” March or April 1996, TRONT archive.
} 
northern boundaries: but their claims, like Waitaha's, were ultimately rejected. ${ }^{417}$ After what Graham has described as “physically and emotionally draining” negotiations a final Deed of Settlement was agreed by November $1997 .{ }^{418}$

\section{Conclusion}

The quantification of historical loss was an important issue for Waikato-Tainui and Ngāi Tahu during their negotiations. While the Crown made clear that political decisions rather than purely quantitative equations would ultimately determine the amount of compensation, Ngāi Tahu nonetheless tried to have the quantification of loss as a factor in their settlement before the decision was gradually made for the $\$ 170$ million fisheries settlement in 1992 that set the benchmark. Eight months after the fisheries settlement was signed, the \$170 million figure was put to Waikato-Tainui negotiator Mahuta long before any kind of discussion about Waikato-Tainui's quantum representing $17 \%$ of the total redress envelope. Graham also had instructed ToWPU officials to point specifically to the fisheries settlement, when seeking Cabinet authorisation for Waikato-Tainui’s settlement. WaikatoTainui also made references to the value of the lands they had confiscated but did not devote the resources that Ngāi Tahu did to the issue. The envelope policy was developed to create some certainty for the Crown's own fiscal planning, and to sell the policy to the public—-both Māori and Pākehā. Its gradual development in the middle of Waikato-Tainui and especially Ngāi Tahu's negotiations was frustrating for each group as they had to deal with the uncertain development of new principles for negotiation. Waikato-Tainui struggled to separate the fiscal envelope policy from its own settlement. Ultimately Ngāi Tahu and Waikato-Tainui’s settlements were connected to the fiscal envelope policy, but the RFR process (and DSP

\footnotetext{
${ }^{417}$ Andew Sharp, "Recent juridical and constitutional histories of Māori," in Andrew Sharp and Paul McHugh (eds.) Histories, Power and Loss (Wellington: Bridget Williams Books, 2001), 48-56.

${ }^{418}$ Graham, “The Treaty and Treaty Negotiations," 172-173.
} 
process for Ngāi Tahu), interest payments on the unpaid sum and the relativity clauses negotiated by Waikato-Tainui and Ngāi Tahu allowed for the prospect of additional financial redress on top of the $\$ 170$ million nominally provided. The relativity clause could in the end provide at least as much again as the initial quantum that was paid--\$170 million.

Both Waikato-Tainui and Ngāi Tahu were able to extend their quantum out past the nominal \$170 million provided to each group. Mahuta commented at a consultation hui at Hukanui Marae in February 1995 that interest was building on the \$170 million “\$400 an hour, 24 hours a day, 7 days a week.” ${ }^{419}$ Waikato-Tainui accumulated around \$20 million in interest alone from 1995-2000 as the settlement was paid out over five years. Ngāi Tahu accumulated around \$25 million since Waikato-Tainui was transferred its compensation in a shorter time span than Ngāi Tahu—hence less interest was paid. The Right of First Refusal (RFR) also provided significant financial leverage to both Waikato-Tainui and Ngāi Tahu. It is unclear exactly how much it was "worth" but one can expect it was at least in the tens of millions. The RFR allowed Waikato-Tainui and Ngāi Tahu to have the first right to purchase Crown properties when they were privatised. Ngāi Tahu was also able to negotiate a Deferred Selection Process (DSP). The Crown's unilateral control of the fiscal limits of WaikatoTainui and Ngāi Tahu’s Treaty settlements was evidence of its overpowering sovereignty in relation to Ngāi Tahu and Waikato-Tainui's rangatiratanga. This was especially emphasised in both the planned overall limit of $\$ 1$ billion for all claims, and the $\$ 170$ million limit for an individual settlement. Nonetheless the RFR, DSP, payment of interest and the relativity clauses were all aspects of Waikato-Tainui and Ngāi Tahu's settlements that were evidence of some measure of their rangatiratanga in the negotiating process.

\footnotetext{
${ }^{419}$ Solomon, "Hukanui marae consultation,” 11 February 1995, RC1, Correspondence Vol 38, Jan - Feb 1995, Box 16, W-T archives, 2-3.
} 


\section{Chapter 3: Settling the land}

The importance of land to Māori has been paramount throughout New Zealand’s history. In the Māori version of the Treaty of Waitangi, Article Two guaranteed to Māori "te tino rangatiratanga,” what Claudia Orange describes as the unqualified exercise of their chieftanship, over "ratou w[h]enua o ratou kainga me o ratou taonga katoa," their lands, villages and treasures. The English version of Article Two of the Treaty of Waitangi guaranteed to Māori "the full exclusive undisturbed possession of their Lands and Estates.” 420 The intimate connections between the people ("tangata”) and land ("whenua”) have been signified in a number of different Māori proverbs such as: "Te toto o te tangata he kai, te oranga o te tangata he whenua” ("The lifeblood of a person is derived from food; the livelihood of a people depends on land"), and "Toitu he whenua, whatungarongaro he tangata” ("The land remains after the people have gone”). ${ }^{421}$ Paerau Warbrick has commented that to Māori the "whenua...is linked with people and the greater cosmos, and incorporates the corporeal as well as the ethereal.",422 As Richard Hill has noted, "land was at the centre of most claims to the Waitangi Tribunal." ${ }^{423}$ Within the framework of the importance of land to Māori, the return of land was a key component in both Waikato-Tainui and Ngāi Tahu's negotiations. The specific connections between mana whenua ("control of the land”) and rangatiratanga were present in both negotiations. Ngāi Tahu felt their mana whenua had been weakened by the loss of their property rights via inadequate reserves and restricted access to mahinga kai. For Waikato-Tainui the confiscation of their lands was a vivid symbol of the way in which their mana whenua was distinctly challenged.

\footnotetext{
${ }^{420}$ Claudia Orange, An Illustrated History of the Treaty of Waitangi, 39.

${ }^{421}$ Hirini Moko Mead and Neil Grove, Nga pepeha a nga tupuna (Wellington: Victoria University Press, 2001), 266, 405.

${ }^{422}$ Paerau Warbrick, “'O ratou whenua', Land and Estate Settlements,” in Nicola Wheen and Janine Hayward (eds.), Treaty of Waitangi Settlements (Wellington: Bridget Williams Books, 2012), 92.

${ }^{423}$ Richard Hill, Māori and the State: Crown-Māori Relations in New Zealand/Aotearoa, 1950-2000, 258.
} 
Ngāi Tahu and Waikato-Tainui both sought to halt the alienation of Crown lands in their respective areas of interest in the wake of the State Owned Enterprises Act 1986. ${ }^{424}$ During Waikato-Tainui’s scoping negotiations in mid-1989 Crown officials were informed by Waikato-Tainui negotiators that the continuing alienation of Crown land was a primary concern. The Treasury official involved in the scoping negotiations attempted to develop a system under which Waikato-Tainui would receive a warning regarding the pending alienation of Crown land and potentially halt the sale. If Waikato-Tainui sought the inclusion of the Crown land in their settlement, it would be placed in a land-bank for future use. Unfortunately there was no support for such a system for Waikato-Tainui from senior Crown officials although it is unclear what the specific rationales were. In October 1989, the Ngāi Tahu Waitangi Tribunal heard closing submissions. Presiding Officer Ashley McHugh brought to the Crown's attention Ngāi Tahu and the Tribunal's concerns with the on-going alienation of Crown land in the South Island. By early 1990 Ngāi Tahu's land-bank was established. Waikato-Tainui followed with the establishment of their land-bank in early 1993.

Although the land-banking process was an innovative method to protect against the alienation of Crown land, the nature of the process could be frustrating for Ngāi Tahu and Waikato-Tainui as there were limits to the amount of land and types of land allowed in each land-bank. ${ }^{425}$ Damian Stone has rightly commented that Crown properties available for landbanking often consisted of the least profitable and hence least desirable Crown lands available. ${ }^{426}$ In addition, as Alan Ward has noted, it was "not easy for claimants to discern, from the information provided, what was important land” in terms of its potential profitiability. ${ }^{427}$ It will be argued in this chapter that many of the issues surrounding the

\footnotetext{
424 See pages $19-22$.

${ }^{425}$ See pages 32-33 for a brief description of land-banks.

${ }^{426}$ Damian Stone, "The Financial and Commercial Dimensions,” 141-142.

${ }^{427}$ Alan Ward, An Unsettled History: Treaty Claims in New Zealand Today, 36.
} 
development and operation of Waikato-Tainui and Ngāi Tahu's land-banks emerged from the Crown's overriding control of the land-banking process in setting the kind of lands that would be available and the total cap on each land-bank.

The return of land was an important aspect of both Waikato-Tainui and Ngāi Tahu’s negotiations, but each iwi approached the ownership of land from different historical contexts. Waikato-Tainui's negotiations were informed by the confiscation of their lands in the 1860s, hence their key negotiating principle that "as land was taken so land must be returned” (“I riro whenua atu, me hoki whenua mai”). The return of land was marked by Waikato-Tainui's efforts to ensure the land could not be alienated again in the future. Waikato-Tainui sought legal mechanisms to retain returned land such as the restoration of land under a form of inalienable customary title rather than fee simple title. Ngāi Tahu’s focus on the quantification of loss was informed by their own negotiating principles - that inadequate reserves had been provided to Ngāi Tahu in the nineteenth century. In the context of their negotiations, Ngāi Tahu did not seek unique legal mechanisms to retain lands as Waikato-Tainui did. ${ }^{428}$ The return of lands in fee simple title was adequate from the point of view of Ngāi Tahu. Nonetheless both Waikato-Tainui and Ngāi Tahu did seek the return of lands without marginal strips. ${ }^{429}$ Ngāi Tahu especially focused on the return of lands without marginal strips for sites of cultural significance-these were specific areas that were incorrectly included in the Crown's purchases such as the Crown Titi Islands.

The return of sites of cultural significance in Ngāi Tahu's negotiations was informed by the Waitangi Tribunal's specific recommendations on the Ngāi Tahu claim. Ngāi Tahu

\footnotetext{
${ }^{428}$ During the negotiations Ngāi Tahu did not explicitly seek a customary form of title. Nonetheless under the unique legislative environment created by the Canterbury earthquakes Ngāi Tahu residents of Tuahiwi have been seeking to have a form of fee simple title provided which allows for the loosening of rural zoning regulations and exemptions from the Rating Act.

${ }^{429}$ Marginal strips are strips of land, usually 20 metres wide, which extend along and abut the landward margins of parts of the foreshore and the beds of other water bodies. Marginal strips are created when the Crown disposes of land. http://www.linz.govt.nz/survey-titles/cadastral-surveying/publications/marginal-strips.
} 
sought the return of fee simple title to sites of cultural significance, many of which were conservation areas: Whenua Hou (Codfish Island), Rarotoka Island, the Crown Titi Islands, the Arahura River, Aoraki (Mount Cook), the bed of Lake Waihora and others. In areas where fee simple title could not be obtained, including especially in the "conservation estate," Ngāi Tahu sought a co-management role. There was significant opposition to the transfer of conservation areas and co-management roles from within government, primarily through the Department of Conservation (DoC), and also from third-party conservation and recreation interests outside of government. Opposition from DoC and third-parties delayed agreement on the return of sites of cultural significance. They also affected the return of three highcountry pastoral leases that were held in the Ngāi Tahu land-bank, Elfin Bay, Greenstone and Routeburn Stations. The Ngāi Tahu section of this chapter will focus on the negotiations regarding the bed of the Arahura River, Whenua Hou (Codfish Island), the Crown Titi Islands, and the three high-country pastoral leases.

Waikato-Tainui’s direct negotiations occurred without a Waitangi Tribunal hearing, and as a result there were no recommendations for the return of specific sites. WaikatoTainui's settlement was ultimately restricted to grievances solely regarding the confiscation of land and was not marked by the environmental management issues that at times dominated the Ngāi Tahu negotiations which encompassed all of Ngāi Tahu’s claims. Nonetheless Waikato-Tainui attempted to have Department of Conservation (DoC) land included in its settlement, or at least a co-management role with DoC for the land in the Waikato-Tainui rohe but there was similar opposition both within and outside government from conservation interests. In addition to conservationists, Waikato-Tainui also had to contend with other thirdparties - former owners of Crown land taken under the Public Works Act—who delayed the return of Crown land in the Waikato-Tainui settlement. 
The political and economic contexts in which Waikato-Tainui and Ngāi Tahu's Treaty settlements were negotiated reflected the Crown's overriding sovereignty and an environment under which the Crown largely controlled the parameters of the process. The Crown's control of the negotiation process extended to the manner in which Crown land was protected from alienation, and the legal form it would be returned, but third-parties also played a prominent role deciding which specific lands were returned.

\section{Part I: Ngāi Tahu}

\section{The operation of Ngāi Tahu's land-bank}

Chapter 1 briefly detailed the establishment of Ngāi Tahu’s land-bank in late 1989 and early 1990 following the conclusion of their Waitangi Tribunal hearings. Although the land-bank was advantageous for Ngāi Tahu there still remained limits to the overall effectiveness of the system nearly two years after which it was in operation-Crown land continued to be alienated. Ngāi Tahu commented to the Crown in late 1991 that in some cases Ngāi Tahu was pressured to release Crown land for alienation due to political and commercial pressure. An example was the surplus Railcorp lands at Christchurch Railway Station that were proposed for commercial development. Ngāi Tahu’s land-bank was also restricted to specific government departments and agencies such as the Department of Survey Lands and Information (DoSLI), the Ministry of Transport, the Department of Conservation, the Ministry of Education, the Ministry of Social Welfare and Landcorp. Ngāi Tahu sought an early warning system for all Crown land and other assets in the Ngāi Tahu rohe. The Crown responded by creating a database of all Crown lands and assets in the Ngāi Tahu rohe and making that database available to Ngāi Tahu but it was incomplete. Ngāi Tahu continued throughout its negotiations to press the Crown to provide further financial information regarding the land and assets it held in the Ngāi Tahu rohe, which reflected the criticisms 
made on a nation-wide basis by Alan Ward that limited information was provided to claimants. ${ }^{430}$

The land-bank was also susceptible to subversion as a result of the offer-back procedures contained within the system. In one case a DoSLI property was offered back to the original owners subject to Section 40 of the Public Works Act 1981, but the offer-back was refused. Shortly thereafter the position of the original owners was reversed and they purchased the property back and quickly on-sold to a private buyer. Ngāi Tahu believed that there had been a "measure of active collusion" involved in the transaction. ${ }^{431}$ These examples represented some of the difficulties that Ngāi Tahu experienced during the early years of the Ngāi Tahu land-bank.

As the negotiations dragged on with little progress in the middle of 1993 Ngāi Tahu expressed its concern with the land-bank process. Ngāi Tahu was concerned that the values ascribed by the Crown to the properties offered for inclusion in the land-bank often differed significantly from the market values of those properties to the detriment of Ngāi Tahu. Ngāi Tahu sought an amendment to the land-bank system under which Ngāi Tahu could provide input into the valuation of properties intended for transfer. Ngāi Tahu also wanted to involve itself in the management of land-bank properties, since they were managed solely by DoSLI until settlement and final transfer to the Crown. ${ }^{432}$ The Crown left open the possibility of new mutually agreed valuations of land-bank properties upon settlement, but did not agree that Ngāi Tahu should be involved in the management of properties contained in the land-bank prior to transfer. The Crown stated that Ngāi Tahu's land-bank arrangements were superior to

\footnotetext{
${ }^{430}$ Ngāi Tahu Negotiating Team to Crown "A" Team Negotiators, "Options for dealing with Crown asset sales," 10 December 1991, C-27-4-02 Vol.1, OTS archive; O’Regan to Treasury, 24 January 1992, "Landcorp South Island Assets," and O’Regan to Justice Secretary, 4 February 1992, "Information on Crown Assets," both: C-274-02 Vol. 2, OTS archive; Ward, An Unsettled History, 36.

${ }^{431}$ O’Regan to ToWPU, “Crown Asset Disposal,” 11 December 1991, C-27-4-02 Vol.1, OTS archive.

${ }^{432}$ O’Regan to Graham, 27 August 1993, C-27-4-02 Vol. 4, OTS archive.
} 
all other land-banks because Ngāi Tahu were able to move properties in and out of their landbank unlike any other land-banks in operation. Additionally, Ngāi Tahu were able to add any property in the Ngāi Tahu rohe to their land-bank, whereas all other negotiating groups had to prove that the property they desired for inclusion into their land-bank had special importance to the claimant group. In the context of Ngāi Tahu's unique land-banking arrangements, the Crown felt that the Ngāi Tahu land-bank was the most generous arrangement in place. ${ }^{433}$

\section{The three high-country pastoral leases: Elfin Bay, Greenstone and Routeburn Stations}

The properties contained in Ngāi Tahu's land-bank, and all other land-banks, were generally restricted to solely Crown land. Early in the negotiation process, Ngāi Tahu expressed an interest in the purchase of a private asset, the Elfin Bay Station high-country pastoral lease on the shores of Lake Wakatipu. In May 1992 the Elfin Bay lease was advertised for sale. ${ }^{434}$ In June 1992 Ngāi Tahu requested the purchase of Elfin Bay Station and an adjoining high-country pastoral lease, Greenstone Station. The Crown agreed. At the time of purchase Ngāi Tahu expected the high-country pastoral leases to immediately be transferred to the Ngāi Tahu Māori Trust Board. Ngāi Tahu raised the precedent of the transfer of Hopuhopu to the Tainui Māori Trust Board, but the Crown maintained that the leases and the former Army Base were different kinds of assets. As a result the leases would be placed in the land-bank and transferred upon settlement. ${ }^{435}$

As the Greenstone station pastoral lease was being purchased by the Crown for inclusion in the Ngāi Tahu land-bank in June 1992, the Minister of Conservation sought to

\footnotetext{
${ }^{433}$ Graham to O’Regan, 27 September 1993, C-27-4-02 Vol. 4, OTS archive.

${ }^{434}$ Graham to Chairman Cabinet Committee on Treaty of Waitangi Issues, "Settlement of the Ngāi TahuMāori Trust Board Claim to the Waitangi Tribunal,” 20 May 1992, C-27-4-07 Vol. 1, OTS archive.

${ }^{435}$ Manager Crown Forest Lands to David Oughton, 19 June 1992; ToWPU official 4 to Graham, 19 June 1992 , both: C-27-4-07 Vol. 1, OTS archive; Ngāi Tahu-Crown meeting minutes, June 1992, C-27-4-02, Vol. 4, OTS archive.
} 
retire 4,534 hectares of the Station into the conservation estate. ${ }^{436}$ Although Ngāi Tahu was very hesitant, they agreed. ${ }^{437}$ Despite Ngāi Tahu’s support for increasing the conservation and recreation values at Greenstone Station by agreeing to the retirement of a large area to the DoC estate, a number of different conservation and sports recreation groups continued to fear Ngāi Tahu’s motives. The Otago Fish and Game Council, a statutorily created sports recreation organisation, expressed its opposition to the transfer of the lease for Greenstone Station because of the potential negative implications that Ngāi Tahu would have for trout angling as the new lessee. The Otago Conservation Board voiced similar opposition charging that Ngāi Tahu would erode the conservation values of the area around Greenstone Station. ${ }^{438}$ The South Otago Branch of the New Zealand Deerstalkers Association also lobbied the government and asked that the entire Greenstone Station be purchased by the Crown for recreational sports interests. ${ }^{439}$ The Southland Fish and Game Council was more moderate and asked to be kept informed of developments as they progressed in relation to recreational fishing access in the Southland section of Elfin Bay Station. ${ }^{440}$ These conservation and sports recreation third-party interests would play a significant role overall in delaying agreement on the return of the high-country leases, and all other conservation aspects of Ngāi Tahu's settlement negotiations.

In July 1992 following the inclusion of the Elfin Bay and Greenstone Station leases in the Ngāi Tahu land-bank, the Crown sought to have a \$40 million cap placed on the total value of Crown properties in the land-bank. This coincided with the debates that took place regarding the overall quantum of Ngāi Tahu's settlement that were explored in Chapter 2.

\footnotetext{
${ }^{436}$ Minister of Conservation to Chairman Cabinet Committee on Treaty of Waitangi Issues, "Greenstone Pastoral Lease: Exclusion from area to go in the Crown Land Bank,” 19 June 1992, C-27-4-07, Vol. 1, OTS archive.

${ }^{437}$ O’Regan to Graham, 6 August 1992, C-27-4-07 Vol. 1, OTS archive.

${ }^{438}$ Les Cleveland to Graham, 30 July 1992, C-27-4-07, Vol. 1, OTS archive.

${ }^{439}$ Kerry O’Donohue to Graham, 29 July 1992: C-27-4-07, Vol. 1, OTS archive.

${ }^{440}$ Niall Watson to Graham, 9 July 1992; MA Rodway to Graham, 28 July 1992, both: C-27-4-07, Vol. 1, OTS archive.
} 
Ngāi Tahu wanted a much larger quantum for their overall settlement than the Crown envisioned, and opposed the $\$ 40$ million limit but ultimately provided its agreement to the cap. ${ }^{441}$ Then in July 1992 Ngāi Tahu requested the purchase of Routeburn Station, a highcountry pastoral lease adjacent to Elfin Bay and Greenstone Stations. ${ }^{442}$ The Crown made contingent the purchase of Routeburn Station on the reduction of the land-bank cap from $\$ 40$ million to \$35 million, and an undertaking from Ngāi Tahu that no further private pastoral leases would be requested for inclusion in the land-bank. Although Ngāi Tahu considered the Crown’s request for the land-bank limit arbitrary, Ngāi Tahu again agreed. ${ }^{443}$ In August 1992, the cap was reduced to $\$ 35$ million and Routeburn Station was added to the landbank. $^{444}$

In October 1992 ToWPU officials met with representatives of two major sports recreation organisations, Hugh Barr, the President of the Federated Mountain Clubs, and Bryce Johnson, the Chairman of the New Zealand Fish \& Game Council. Barr stressed that there was great concern with the use of Greenstone Valley, Elfin Bay and Routeburn Stations as Treaty settlement redress. Barr wanted the government to re-categorise the land contained in the stations into three new categories: farming, conservation, and recreational. Both Barr and Johnson sought an active role in consulting with the Department of Conservation to determine the proportion of the new land categories within the three high-country stations. A ToWPU official reported to his superiors that Barr and Johnson "maintained that they did not want to interfere with the resolution of Ngāi Tahu's grievances where this concerns

\footnotetext{
${ }^{441}$ Graham to O’Regan, undated but most likely July 1992; Ngāi Tahu-Crown meeting minutes, 24 July 1992, both: C-27-4-02, Vol. 4, OTS archive; CSC (92) 387, C-27-4-07 Vol. 1, OTS archive.

${ }^{442}$ CAB (92) 643; ToWPU official 4 to Graham, "Ngāi Tahu Negotiations: Advance on Settlement,"31 July 1992, both: C-27-4-07 Vol. 1, OTS archive.

443 O’Regan to Manager Crown Forest Lands), 13 August 1992, C-27-4-07, Vol. 1, OTS archive.

${ }^{444}$ CAB (92) M23/10a, C-27-4-02 Vol. 4, OTS archive. In July 1993 Ngāi Tahu sought another high-country pastoral lease, at Glenmore Station, but the Crown was very hesitant and in the end Glenmore Station was taken off the market before it was ever sold. Graham, "Purchase of Glenmore Station for Part Settlement of the Ngāi Tahu Claim,” 8 July 1993; ToWPU official 10 to Treasury official 8, “Re Glenmore Station,” 12 July 1993, both: C-27-8-01 Vol. 6, OTS archive.
} 
commercial interests. They do, however, want to have a chance to represent their constituents' interests (and what they see as the wider public interest)...” The ToWPU officials stated to Barr and Johnson that Ngāi Tahu had always stressed that they would not restrict public access to areas of conservation/recreation value. ToWPU officials also pointed out that Ngāi Tahu was bound by the same public access provisions as previous lessees. The officials indicated that Ngāi Tahu had a strong commitment to conservation principles, and had indicated a desire to enter into joint management projects with the Crown to put these into effect. ${ }^{445}$

The ToWPU officials recommended that the Fish \& Game Council and FMC write directly to DoC and ToWPU explaining that they have undertaken assessment work on the areas in question, and that they wished to be part of a consultation process to determine which parts of the high country leases in question the Crown would retain for conservation/recreation purposes and public access rights. Barr and Johnson remained sceptical of Ngāi Tahu’s motivations despite the Crown's assurances. ${ }^{446}$ Johnson wrote to Graham following the meeting with ToWPU officials, and sought an undertaking that conservation and sports recreation organisations would be consulted before any settlement offers were made to Ngāi Tahu. ${ }^{447}$

In July 1993, as a result of political pressure from conservation and sports recreation advocates both within and outside government, the Department of Conservation produced a report that recommended the retirement of a large proportion of the three high-country pastoral leases into the conservation estate. The report stated that large areas of the leases

\footnotetext{
445 ToWPU official 4, "Meeting with Fish \& Game Council and Federated Mountain Clubs,” 20 October 1992: C-27-7-04 Vol. 1, OTS archive

${ }^{446}$ ToWPU official 4, "Meeting with Fish \& Game Council and Federated Mountain Clubs," 20 October 1992; Barbara Marshall (FMC) to Graham, 21 October 1992; Bryce Johnson to Graham, 21 October 1992, all: C-27-704 Vol. 1, OTS archive.

447 Johnson to Graham, 28 October 1992, C-27-7-04 Vol. 1, OTS archive.
} 
were high-value conservation lands and were unsuitable for pastoral grazing. Ngāi Tahu was concerned that after having already agreed to the retirement of 4,534 hectares into the conservation estate from Greenstone Station when it was first purchased in July 1992, further sections of the Station would now be similarly affected. ToWPU officials conveyed the concerns of Ngāi Tahu to Graham. A ToWPU official commented to Graham that "discussion of certain options, namely conditional vesting of land title and unconditional vesting of land title, were removed by DOC staff from the draft before it was sent to TOWPU for despatch to the NGOs. While this rewrite may suit the views of the NGOs, it may not suit those of iwi.”"448 ToWPU officials felt that DoC was having a negative effect on Ngāi Tahu's negotiations.

Ngāi Tahu felt that the pressure from DoC had undermined their aspirations for Greenstone Valley tourism development. During formal negotiations with the Crown O’Regan commented that "Ngāi Tahu appreciate the conservation values but not the proposals contained in the report. They are aware of the botanical values but are concerned that the protection of red tussock will damage the economic viability of the area; if so, they would require compensation.”449 O’Regan complained to Graham that Ngāi Tahu would not accept the three high-country pastoral leases unless they were a viable farming unit. Graham stated that the Crown had originally intended to transfer the lease to Ngāi Tahu but that consultation with conservation groups had to take place. ${ }^{450}$ Despite the favourable report from DoC, conservation and sports recreation interests continued to press the government over the use of the three high-country leases in 1993 and 1994.

\footnotetext{
448 ToWPU official 11 to Graham, 15 June 1993, AAKW W5105 7812 5, Archives NZ, 1.

449 "Meeting between Crown and Ngāi Tahu Negotiators," 1 July 1993, C-27-2-02 Vol. 2, OTS archive.

${ }^{450}$ Graham to O’Regan, 21 September 1993, NT140, F(i)1 Box 129, MB archives.
} 
The negotiation with Ngāi Tahu was completely stalled for most of 1992 well into 1996 but to conservation and sports recreation organisations a settlement always seemed to be imminent. These organisations continually stressed that further consultation was needed no matter how much the Crown conferred with conservation groups. From the evidence it seems that there was wide consultation. ${ }^{451}$ In addition to the Federated Mountain Clubs, the New Zealand Fish \& Game Council and Conservation Boards, other organisations that were vocal in their opposition to the use of the high-country pastoral leases were the Royal Forest \& Bird Protection Society, a conservation group, and Public Access New Zealand (PANZ), a sports recreation group. Graham spoke to members of PANZ and corresponded with their Director, Bruce Mason. ${ }^{452}$ Ngāi Tahu had concerns about the effect that PANZ could have on the high-country pastoral leases aspect of any final settlement. ${ }^{453}$

As Ngāi Tahu's negotiations slowed as result of the development of the fiscal envelope policy in 1993 and 1994, Ngāi Tahu commented to the Crown that the public consultation process had been hijacked by special interest groups such as PANZ. Conservation groups made the same comments of Ngāi Tahu to the Crown. Catherine Wallace of the Environment and Conservation Organisations, an umbrella group of conservation organisations in New Zealand, specifically asked Doug Graham that at future public consultations Ngāi Tahu not be present. ${ }^{454}$ At some of the public consultations Ngāi

\footnotetext{
${ }^{451}$ Graham to Royal Forest \& Bird Society, Environmental and Conservation Groups, NZ Fish and Game Council, Maruia Society, FMC, NZ Deerstalkers Association and the NZ Conservation Authority, 16 December 1991; Catherine Wallace to Graham, 4 April 1992; Richard Hill, "Meeting with Fish \& Game Council and FMC,” 20 October 1992; Denis Marshall to Graham, 7 December 1992: all C-27-7-04 Vol.1;Denis Marshall, "Speech to the Federated Mountain Clubs," 12 June 1993, NT140 G20b, Macmillan Brown archive; BF Webb to Sid Ashton, 21 March 1994, NT140 M4 (g), Macmillan Brown archive; DoC official 1, "Consultations for Ngāi Tahu ,” 11 May 1994, C-27-7-04 Vol. 1; Graham, “Speech to Public Access NZ,” June 1994, C-27-7-04 Vol. 1; Graham, "Ngāi Tahu Negotiations: Preliminary Crown Position on Sites of Recreational and Conservation Interest, 17-18 September 1996 in Christchurch and Dunedin”, Vhi 52c (r), TRONT archive.

452 Bruce Mason to Graham, 12 November 1991; Graham to Mason, 3 December 1991; Mason to Graham, 24 November 1992; Graham to Mason, 19 February 1993 all: C-27-7-04 Vol. 1, OTS archive; Mason to Graham, 2 May 1994; Graham to Mason, 25 May 1994; C-27-7-03 Vol. 1, OTS archive;

453 "Meeting between Crown and Ngāi Tahu Negotiators," 18 July 1994, C-27-2-02 Vol. 3, OTS archive.

${ }^{454}$ Catherine Wallace to Graham, 4 April 1992, C-27-7-04 Vol.1.
} 
Tahu negotiators felt that a disproportionate amount of time was given to speakers who opposed Ngāi Tahu. ${ }^{455}$ Ngāi Tahu negotiator Edward Ellison had asked Sid Ashton, the Ngāi Tahu Māori Trust Board (NTMTB) Secretary, to investigate the alleged racist tendencies of the Otago Fish \& Game Council because of their opposition to the transfer of the three highcountry pastoral leases. ${ }^{456}$ At the June 1994 Crown-Ngāi Tahu meeting Ngāi Tahu made it known that it had strong reservations with the manner in which the North Canterbury and Southland Conservation Boards ran their public consultation processes, and that Ngāi Tahu preferred a different body to conduct the consultation with "less vested interest." ${ }^{457}$ When the negotiations broke down in late 1994, the three high-country leases remained in the landbank.

In 1995 Graham and O’Regan exchanged a number of letters regarding the difficulty of dealing with conservation interests. While Graham tried to merely stress that conservation interests had to be dealt with, O’Regan tried to counter that Ngāi Tahu's Treaty rights should not be trampled upon by conservationists because of alleged “public interest.” O’Regan specifically pointed to the concession that Ngāi Tahu provided by agreeing to the retirement of land from the Greenstone Station lease when the lease was first included in the land-bank in July 1992. ${ }^{458}$ Graham’s difficulties were increased by the continuing hard line that

\footnotetext{
455 O’Regan to Graham, 8 March 1994 and 3 June 1994; “Minutes of a Meeting between Crown and Ngāi Tahunegotiators,” 16 March 1994, C-27-2-03 Vol. 3; "Minutes of Public Consultation Process Hui by the Ngāi Tahu Māori Trust Board,” 22 April 1994; C-27-7-04 Vol. 1.

${ }^{456}$ Edward Ellison to Ashton, 2 June 1994, Vhi 16 (t), TRONT archive.

${ }^{457}$ DoC official 2 to ToWPU official 11, 18 January 1994, AAKW W5105 7812 5, Archives, NZ; "Minutes of a meeting between Crown and Ngāi Tahu negotiators”, 8 June 1994, C-27-2-02 Vol. 3, OTS archive, 2. Hostile consultation processes regarding Treaty settlements and indigenous rights has also been explored by Canadian authors: Anthropologist Elisabeth Furniss in the British Columbian context during the same time period in the Cariboo-Chicotlin area and by journalist Alex Rose in his history of the Nisga'a claim: Elisabeth Furniss, Burden of History: Colonialism and the Frontier Myth in a Rural Community (Vancouver: UBC Press, 1999); Rose, Spirit Dance at Meziadin: Chief Joseph Gosnell and the Nisga'a Treaty.

458 O’Regan to Graham, 20 February 1995; Graham to O’Regan, 17 March 1995; O’Regan to Graham, 20 March 1995, NE-18-027-00-01, OTS archive.
} 
conservationists held in 1995 despite the release of government policy which stated that only small and discrete sites of conservation lands were available for settlements. ${ }^{459}$

As the negotiations were in the early stages of recommencing in early 1996 the Commissioner for Crown Lands produced a report which recommended that $90 \%$, or approximately 75,000 acres, of the three high-country pastoral leases be retired into the conservation estate. The Commissioner for Crown Lands’ March 1996 report reflected the same conclusions reached in the July 1993 DoC report. TPK opposed the report's proposals and commented to ToWPU officials that "such a recommendation appears not to take account of the Crown's objective to settle the Ngāi Tahu claim. This para[graph] should note why Ngāi Tahu regard the stations as important to their settlement, and any barriers to having them included? For example do they have high conservation values?” DoC added some significant conservation information to the final Cabinet paper to underscore the conservation implications for the three high-country pastoral leases. Due to the contradictory advice from TPK and DoC, Cabinet declined to make a decision on the high-country pastoral leases stating that it was "a difficult issue which requires further consideration by the Crown and should be dealt with later in the negotiations in the context of other outcomes."460 The recommendations of the Commissioner of Crown Lands’ report would later become entrenched, and large areas of the pastoral leases were retired into the conservation estate.

In contrast to conservation and public access groups, the South Island High Country Committee of Federated Farmers was particularly supportive of Ngāi Tahu as potential high country lessees, especially since the three high-country pastoral leases had been commercial

\footnotetext{
${ }^{459}$ Office of Treaty Settlements, Crown Proposals for the Settlement of Treaty of Waitangi Claims (Wellington: Department of Justice, 1994).

460 TPK official 3 to OTS official 3, 20 March 1996 \& Minister of Treaty Negotiations to Cabinet Strategy Committee, "Ngāi Tahu: specific assets with conservation implications," 31 March 1996, both: NE-12-027-0002 Vol. 3, OTS archive; CSC (96) M 10/3a, b\&c, NE-12-027-00-02 Vol. 4, OTS archive.
} 
properties for many years. The South Island High Country Committee stated that a regrettable racial element had been injected into the debate over high country land reform. "Pastoral leases are being bought and sold all the time. Therefore, the hard question has to be asked, why is PANZ mounting a petition against these transactions and not others? The answer is that PANZ senses a political advantage in exploiting fears and prejudices in relation to Māori and proposed treaty settlements.” The support of high-country farmers was perhaps not so surprising considering their own connections with the high-country which as the Waitangi Tribunal had noted was not so different from the connections to the land claimed by Ngāi Tahu. Individual high-country farmers such as H.A.P Barker of Queenstown also expressed their support for Ngāi Tahu. ${ }^{461}$ Ngāi Tahu had invested a lot of time and effort into building and maintaining a positive relationship with Federated Farmers.

Prime Minster Bolger expressed sympathy for Ngāi Tahu regarding the leases. In August 1996 Bolger told Ngāi Tahu negotiators that the Crown would never have purchased the leases if Ngāi Tahu had not requested that they purchase them for inclusion in their settlement. Private interests would have purchased the leases, and it would have been impossible for the Crown to have obtained them for inclusion in the conservation estate. ${ }^{462}$ This seemed to affirm Ngāi Tahu's negative opinion of conservation interests who had fought the Crown and Ngāi Tahu over their planned use of the stations. When the negotiations were approaching an Agreement in Principle the conservation and sports recreation organisations

\footnotetext{
${ }^{461}$ R. Haworth to O’Regan, 4 October 1997, VB 256 (l), TRONT archive; South Island High Country Committee of Federated Farmers of NZ, "Farmers Stand by Defence of Ngāi Tahu ," 23 March 1995, MB archive; Waitangi Tribunal, The Ngāi Tahu Report, 1040-1042; Michele D. Dominy, "White Settler Assertions of Native Status,” American Ethnologist, Vol. 22, No. 2 (May, 1995), 358-374; H.A.P Barker to Graham, 23 September 1996, Vhi 54j, TRONT archive.

${ }^{462}$ Ashton, "Wakatipu Titles,” 19 August 1996, Vhi 52 (g), TRONT archive.
} 
resumed their heated opposition to the use of the high-country pastoral leases in the Ngāi Tahu settlement. ${ }^{463}$

Before the signing of the agreement in principle in early October 1996 Bryce Johnson of the national Fish \& Game Council played a pivotal role in organising consultation with conservation groups, after acting as the concerted opposition early in the negotiations. The consultations continued throughout the negotiation to a final agreement. Forest \& Bird and PANZ refused to attend nearly all of these consultations and then released selective quotes about the settlement and its provisions. Forest \& Bird and PANZ made no mention of the 75,000 acres of land that Ngāi Tahu was being forced to contribute to the conservation estate from the three high-country pastoral leases in their publications. ${ }^{464}$ The situation would have been particularly frustrating for both groups of negotiators, as it was Forest \& Bird which only in August 1996 had pleaded with the government to engage in consultation with conservation groups. ${ }^{465}$

Not only was public access guaranteed but it was markedly improved, so much so that some commentators worried that the "wander at will” provisions would create unfortunate precedents for future settlements. At a meeting of the Select Committee on Māori Affairs to discuss their settlement legislation, Ngāi Tahu negotiators were cross-examined by MPs during the final day of deliberations over fears that the provisions which were included into the high-country pastoral leases aspects of the settlement would be used as a precedent by the government in other Treaty settlement negotiations. Ngāi Tahu negotiator Anake Goodall said that Ngāi Tahu were not satisfied with the result, but that conservation politics had

\footnotetext{
${ }^{463}$ Barbara Marshall to Bolger, 12 September 1996, NE-18-027-00-01, OTS archive; "Fears land deal could exclude public access", Otago Daily Times, 3 October 1996.

${ }^{464}$ OTS official 2 to Bolger, 5 August 1996, NE-10-027-00-02 Pt.1, OTS archive; Anake Goodall, "File Note of meeting with Prime Minister,” 6 August 1996, TRONT archive; Ashton, “Handwritten Notes,” 13, 15, 19, 20 August 1996, Vhi 52 (g), TRONT archive.

${ }^{465}$ Valerie Campbell to Graham, 4 August 1996, NE-18-027-00-01, OTS archive.
} 
played a major part in Crown changes to the terms of the original agreement on high-country pastoral leases. NZ First MP Tutekawa Wyllie stated that he understood the Ngāi Tahu position but asked: "where are we to go in terms of future settlements if the nature of the Ngāi Tahu settlement may be detrimental to the ability of other iwi to settle?” Goodall replied that he was painfully aware of their responsibilities and stated that they had tried to hold the land under the same terms as neighbouring private landowners. Goodall stated that "It is a dark irony that the access requirement was imposed as part of the settlement of a grievance over Māori being treated differently because of their race.”466 In the end a large majority of the three high-country stations were added to the conservation estate and Ngāi Tahu farms the remaining area. While most Treaty settlements represent situations in which land is transferred from the Crown to Māori claimants, the retirement of over 75,000 acres of previously private high-country pastoral leases resulted in the Crown acquiring land from Ngāi Tahu’s Treaty settlement.

\section{The return of sites of cultural significance}

The lands that were contained in the Ngāi Tahu land-bank, including the remaining area of high-country pastoral leases, largely represented Ngāi Tahu’s commercial aspirations. ${ }^{467}$ In addition to those lands Ngāi Tahu also sought the return of specific sites of cultural significance. The negotiations regarding the Arahura River, the Crown Titi Islands and Whenua Hou (Codfish Island) were indicative of the difficulties that Ngāi Tahu experienced in reaching an agreement with the Crown on other sites of cultural significance such as the return of Rarotoka Island, Aoraki (Mount Cook), the bed of Lake Waihora,

\footnotetext{
${ }^{466}$ Tina Nixon, “Fear precedent set with Ngāi Tahu deal,” 19 June 1998, The Southland Times; Interview with Anake Goodall, 7 May 2011.

${ }^{467}$ It also addressed the need to justify Ngai Tahu's arguments during the Waitangi Tribunal hearings that Ngai Tahu had not intended to sell the mountains of Central Otago and Canterbury, the "hole in the middle" of the southern South Island: Waitangi Tribunal, The Ngai Tahu Report, 6.
} 
Tutaepatu Lagoon, Kaitorete Spit and others. Third-party interests played a prominent role in the negotiations over these important sites, much like the use of high-country pastoral leases, and delayed an agreement for over four years.

\section{The Arahura River}

The Waitangi Tribunal had found that the Crown had "acted in breach of its Treaty obligations in failing to meet the wishes of Ngāi Tahu to retain ownership of the pounamu in and adjacent to the Arahura and its tributaries.”468 The Waitangi Tribunal had recommended that the Arahura River and all its tributaries be vested in the Mawhera Incorporation or another body nominated by Ngāi Tahu. ${ }^{469}$ The Arahura Valley has traditionally been one of the principal sources of pounamu (greenstone) for Ngāi Tahu. Pounamu represented both power and survival for Ngāi Tahu and was recognised as both a sacred object and a valuable commodity. ${ }^{470}$ Despite the specific recommendation of the Waitangi Tribunal regarding the Arahura River, the process of vesting the River was complicated by conservation interests both within and outside government. The Crown and Ngāi Tahu had largely agreed that it would be more cost-efficient to identify the catchment area of the Arahura River and its tributaries to their respective sources and transfer that catchment to Ngāi Tahu, while ensuring the maintenance of conservation values and public access. When DoC consulted with conservation NGOs regarding the catchment transfer proposal there was opposition. The conservation NGOs were concerned about preserving conservation values and public access to the Arahura Valley. ${ }^{471}$

\footnotetext{
${ }^{468}$ Waitangi Tribunal, The Ngāi Tahu Report, 725.

${ }^{469}$ Waitangi Tribunal, The Ngāi Tahu Report, 1061.

${ }^{470}$ Russell Beck and Maika Mason, Pounamu Treasures: Nga Taonga Pounamu (Auckland: Penguin, 2012). The Crown continued to provide consent to private companies to mine pounamu in the Arahura Valley: O’Regan to Graham, 24 January 1992, Vhi 9a(c), TRONT archive.

471 "Meeting of Crown and Ngāi Tahu negotiators," 4 February 1992, C-27-8-01 Vol. 1, OTS archive.
} 
As a result of public consultation, DoC changed the parameters of the previous agreement. In an October 1992 report DoC recommended the establishment of a Reserve governed by the Reserves Act 1977. Ngāi Tahu was opposed to the reserve status proposed which O’Regan described as incorporating “effective powers of confiscation.” O’Regan believed that:

a formula governed by the Reserves Act which would make us tenants, subject to ejection under the current or future legislation, would be demeaning in the extreme and is quite inappropriate. It is our belief that the Tribunal recommendation to return the title, which is itself a reflection of the importance placed by the Tribunal on this taoka $^{472}$, can be achieved at the same time as providing for the Crown's objectives of maintenance of conservation values and public rights of access. This issue lies at the heart of the restoration of the Crown's mana ${ }^{473}$.

By linking the Crown's mana to Ngāi Tahu's rangatiratanga O’Regan was expressing to the Crown the intimate connection that existed between the two processes under the Treaty of Waitangi and that by vesting the Arahura catchment in Ngāi Tahu "there could be few more tangible ways to confirm Ngāi Tahu's Tino Rangatiratanga." ${ }^{474}$ The DoC position to establish a Reserve became entrenched by the Crown, and Ngāi Tahu remained opposed to the reserve proposal. In March 1993 Ngāi Tahu re-affirmed its desire for the vesting of the River and its tributaries into the Mawhera Incorporation. The Crown maintained that the reserve status was the only option available. ${ }^{475}$

In addition to the Tribunal's recommendations regarding the vesting of the Arahura River, the Tribunal also recommended a survey of the entire river and its tributaries. Once Ngāi Tahu and the Crown reached an impasse on the issue of vesting, Ngāi Tahu still pressed

\footnotetext{
${ }^{472}$ In the Ngāi Tahu dialect of the Māori language, the "ng" is often replaced with a "k". Hence "taonga", or treasured possession, is “taoka”.

${ }^{473}$ The meaning of mana is many and varied but in this case signifies the Crown's honour.

474 "Minutes of a meeting between Crown and Ngāi Tahu negotiators," 30 September 1992, C-27-2-02 Vol. 2, OTS archive.

475 O’Regan to Graham, 25 March 1993, C-27-2-02 Vol. 2; "Minutes of a meeting between Crown and Ngāi Tahu negotiators,” 31 March 1993; O’Regan to ToWPU official 11, 6 April 1993; ToWPU official 11 to O’Regan, 8 April 1993; ToWPU official 10 to Graham, 29 June 1993; Graham to O’Regan, 18 October 1993, all: C-27-2-02 Vol. 2, OTS archive; "Minutes of a meeting between Crown and Ngāi Tahu negotiators," 4 May 1994, C-27-2-02 Vol. 3, OTS archive.
} 
for a survey of the area. The Crown complained that the cost of a survey was prohibitive. Ngāi Tahu responded that a survey would be unnecessary if the entire catchment were transferred to the Mawhera Incorporation as the Tribunal had recommended. ${ }^{476}$ For the rest of 1993 and throughout 1994 until the breakdown of the negotiations in November 1994, the opposing Crown and Ngāi Tahu positions on the Arahura River remained firm.

When negotiations slowly began to recommence in the first half of 1996, the Crown recognised that it would have to shift in some way their position on the Arahura River to reach an agreement, but so did Ngāi Tahu. ${ }^{477}$ Ngāi Tahu understood that the Crown refused to vest the catchment, and that Ngāi Tahu would have to maximise their opportunities within the reserve status of the area. Conservation groups pressed for the classification of the Arahura River area as a scenic reserve. Ngāi Tahu countered that if the area was going to be classified as a reserve against the wishes of Ngāi Tahu, it should be classified as a historic reserve. While both reserves have the same public access provisions in the Reserves Act 1977, scenic reserves are specifically designed for the use of the public while historic reserves are not. Late in the negotiations in September 1996, conservation interests sought to have the scenic value of the area recognised in addition to the historic reserve sought by Ngāi Tahu. ${ }^{478}$ Ultimately the Waitaki Historic Reserve was vested in the Mawhera Incorporation. Ngāi Tahu was unable to have the entire catchment vested in the Mawhera Incorporation as it had originally requested, but Ngāi Tahu was at least able to have the area recognised as a historic reserve. ${ }^{479}$ Much like the wider political structure of the negotiation process and the discussions over the economic rationales for compensation, there were limits to the Ngāi

\footnotetext{
476 "Minutes of a meeting between Crown and Ngāi Tahu negotiators," 26 January 1994, C-27-2-02 Vol. 3, OTS archive.

${ }^{477}$ DPMC official 3 to Bolger, 28 February 1996, NE-12-027-00-02 Vol. 2.

${ }^{478}$ Goodall, "File note of telephone conservation with [OTS official 2],” 27 September 1996, Vhi 52b (d), TRONT archive; Reserves Act 1977, Sections 18 and 19.

${ }^{479}$ Ngāi Tahu Deed of Settlement, 21 November 1997, Section 13.3.2.
} 
Tahu control of the process, but small concessions were gained that were important to the integrity of the settlement from the Ngāi Tahu perspective.

\section{Whenua Hou and the Crown Titi Islands}

The Titi islands have been an important part of the Ngāi Tahu economy for centuries. The titi or mutton-birds that were and continue to be harvested on the islands were not only a traditional food source but also a tradeable commodity. ${ }^{480}$ When Rakiura (Stewart Island) was sold in 1864, twenty-one of the neighbouring islands, those closest to Rakiura, were reserved for Ngāi Tahu from the purchase. They became known as the Beneficial Titi Islands. The Crown took ownership of the remaining islands which became known as the Crown Titi Islands. The Waitangi Tribunal found that the Crown should have reserved all of the islands neighbouring Rakiura, and recommended that "beneficial ownership of the Crown Titi Islands be vested in such persons or bodies as may be nominated by Ngāi Tahu and be subject to a similar management as the beneficial Titi Islands.” Whenua Hou (Codfish Island) near Rakiura (Stewart Island) is known as the ancestral home of Rakiura Ngāi Tahu. Whenua Hou was one of the original stopping off places for southern Ngāi Tahu on their way to the Titi Islands. During the Tribunal hearings Rakiura Ngāi Tahu did not deny that Whenua Hou was included in the purchase of Stewart Island, but they complained about being denied access to Whenua Hou. The Waitangi Tribunal recommended that "subject to prior notification and to arrangements with conservation authorities, free access be available to Rakiura Māori to visit the island but consistent at all times with the security of wild-life on

\footnotetext{
${ }^{480}$ Michael Stevens, "Settlements and 'Taonga': A Ngāi Tahu Commentary," in Nicola Wheen and Janine Hayward (eds.) Treaty of Waitangi Settlements (Bridget Williams Books: Wellington, 2012), 135; Michael Stevens, "Muttonbirds and modernity in Murihiku: continuity and change in Kai Tahu knowledge," Ph.D Thesis, University of Otago, 2009.
} 
the island.” ${ }^{481}$ The two different sets of recommendations of the Tribunal reflected the different forms of land-based redress that Ngāi Tahu and the Crown would develop together.

The return of the Crown Titi Islands was one of the most integral aspects of the Ngāi Tahu claim and Rakiura Ngāi Tahu in particular were very concerned that its return be effected. ${ }^{482}$ Although the Waitangi Tribunal had not recommended the return of Whenua Hou to Ngāi Tahu, O’Regan argued that its return would re-affirm the Crown’s commitment to recognising Ngāi Tahu’s rangatiratanga. Specifically O’Regan sought to establish what he termed a "joint title" approach in which both the Crown and Ngāi Tahu would share title to important sites such as Whenua Hou. ${ }^{483}$

Early in one of the first formal meetings between the Crown and Ngāi Tahu in late 1991 there was initially some limited support from DoC for the “joint title” approach proposed by Ngāi Tahu, but only if Ngāi Tahu also agreed to co-manage the Crown Titi Islands. This support for co-management at Whenua Hou was limited to Ngāi Tahu participation in an advisory capacity to the primary control of DoC, rather than the "joint title” co-management envisioned by Ngāi Tahu. ${ }^{484}$ When the Crown consulted with thirdparty conservation organisations there was positive support for a Ngāi Tahu advisory role at Whenua Hou. ${ }^{485}$ Conservation organisations opposed Ngāi Tahu’s proposed “joint title approach.”486 In June 1992 DoC formally proposed the establishment of a Reserves Board for

\footnotetext{
${ }^{481}$ Waitangi Tribunal, Ngāi Tahu Report, 1064.

${ }^{482}$ Harold Ashwell to Waitangi Tribunal, 17 August 1991, Vhi 9b(f), TRONT archive; "Meeting between Ngāi Tahu, Department of Conservation and Treaty of Waitangi Policy Unit officials,” 1 October 1991, C-27-2-03 Vol. 1, OTS archive.

483 "Minutes of Meeting between Ngāi Tahu and Crown Negotiators," 30 October 1991, C-27-2-03 Vol. 1, OTS archive.

484 "Minutes of Meeting between Ngāi Tahu and Crown Negotiators," 30 October 1991, C-27-2-03 Vol. 1, OTS archive.

485 "Minutes of Meeting between Ngāi Tahu and Crown Negotiators," 4 February 1992, C-27-8-01 Vol. 1, OTS archive.

486 “Minutes of Meeting between Ngāi Tahu and Crown Negotiators,” 6 October 1993, C-27-2-02 Vol. 2, OTS archive
} 
Whenua Hou with a majority of the Board reserved for Rakiura Ngāi Tahu while Ngāi Tahu still pushed for a "joint title” approach at Whenua Hou. ${ }^{487}$

O’Regan believed that the “joint title approach is relevant in the context of Whenua Hou and, may well be relevant across a much wider spectrum of settlement within Ngāi Tahu's rohe. We believe the Australian and Canadian models in this area are instructive and find it difficult to understand why NZ should find it so difficult." ${ }^{488}$ The link to Treaty settlement developments in Canada and Australia was used by Ngāi Tahu throughout the negotiations to stress that the precedents for recognising the rangatiratanga of indigenous groups in other former British colonies existed, but the idea did not gain much traction with the Crown. The co-management arrangements sought by Ngāi Tahu were not accepted by the Crown, which wanted to provide Ngāi Tahu an advisory role at the conservation board or reserves board level. During the March 1993 negotiations O’Regan noted that Ngāi Tahu continued "to be interested in the concept of shared title, for example, as for Ayers Rock [Uluru] in Australia.”489 O’Regan tried to stress that Ngāi Tahu did not seek to challenge DoC's role. "In the case of the wider conservation estate this would not mean operational control or co-management as management is the business of the DoC. Ngāi Tahu would, however, seek control of the Ngāi Tahu cultural context, ie, names etc.” The Crown responded that their co-management proposal for Whenua Hou was fully consistent with the

\footnotetext{
${ }^{487}$ DOC official 2 to O’Regan, 23 June 1992, Vhi 13 (k) Box 150, TRONT archive.

${ }^{488}$ O’Regan to Graham, 25 March 1993, C-27-2-02 Vol. 2, OTS archive.

${ }^{489}$ In 1985 Ayers Rock or Uluru was returned as freehold title to the local Aboriginal community and leased back to the Australian government. Uluru is co-managed by a Park Board with an Aboriginal majority: David Lawrence, "Managing Parks/Managing 'Country': Joint Management of Aboriginal Owned Protected Areas in Australia,” Research Paper 2 1996-97, Parliament of Australia.
} 
Tribunal's recommendations and that the concept of 'joint title” would not be investigated further as the approach was unacceptable to the Crown. ${ }^{490}$

While Whenua Hou was not available for transfer or as a “joint title” approach, the Crown Titi Islands remained available but it was unclear how the transfer would be specifically achieved. At first DoC proposed that the Crown Titi Islands be co-managed by the Crown and Ngāi Tahu together. Ngāi Tahu continued to seek sole fee-simple ownership of the Crown Titi Islands. ${ }^{491}$ After Ngāi Tahu rejected the Crown’s proposal to co-manage the Crown Titi Islands with DoC, the Crown accepted that a transfer would occur. The Crown envisioned Ngāi Tahu managing the Crown Titi Islands in the same manner as the Beneficial Titi Islands. ${ }^{492}$ For the large part Ngāi Tahu and the Crown were in agreement regarding the vesting of the Crown Titi Islands. ${ }^{493}$ Ngāi Tahu's only request for the Crown Titi Islands was that the vesting of the Islands occurs without a marginal strip. From Ngāi Tahu's perspective marginal strips were created when the Crown disposed of land, but the return of land in a Treaty settlement was a different proposition that did not carry the same obligations. Many of the Titi Islands that were being returned had steep seashore cliffs which contained important Titi nesting sites that would be covered by the marginal strips. In addition, Ngāi Tahu preferred the return of land without any Crown encumbrances. The Crown cautiously agreed to Ngāi Tahu's proposal but stated to Ngāi Tahu that the matter would have to be determined

\footnotetext{
490 "Minutes of Meeting between Ngāi Tahu and Crown Negotiators," 31 March 1993; ToWPU official 11 to Graham, 27 April 1993; "Minutes of Meeting between Ngāi Tahu and Crown Negotiators," 28 April 1993; ToWPU official 10 to Graham, 29 June 1993: C-27-2-02 Vol. 2, OTS archive.

491 "Minutes of a meeting between Ngāi Tahu and Crown Negotiators," 1 March 1992, C-27-8-01 Vol. 1, OTS archive.

${ }^{492}$ CSC (92) 89, C-27-2-02 Vol. 2, OTS archive.

${ }^{493}$ O’Regan to Graham, 25 March 1992, C-27-2-02 Vol. 2, OTS archive.
} 
by public consultation, like other conservation matters such as the Arahura River and the high-country pastoral leases. ${ }^{494}$

Consultation was planned with the Southland Conservation Board. Ngāi Tahu was concerned about the effect that conservation third-party interests might have on the negotiation for the return of the Crown Titi Islands. ${ }^{495}$ The Ngāi Tahu negotiators had developed a draft deed for the management structure that would govern the Titi Islands. ${ }^{496}$ The Crown wanted to release the draft deed of the Titi Islands management structure to another conservation organisation in addition to the Conservation Board, the Royal Forest \& Bird Protection Society. Ngāi Tahu was concerned that Forest \& Bird would oppose the waiving of the marginal strip and derail the agreement that had been reached. The Crown noted that there were advantages to releasing the deed as it would allow the Crown to allay any concerns Forest \& Bird may have with the proposal. ${ }^{497}$

The Crown's consultation with the Southland Conservation Board regarding the proposal for a Reserves Board at Whenua Hou and the transfer of freehold title to the Crown

\footnotetext{
494 "Minutes of Meeting between Ngāi Tahu and Crown Negotiators," 31 March 1993, C-27-2-02 Vol. 2, OTS archive.

495 “Minutes of Meeting between Ngāi Tahu and Crown Negotiators," 28 April 1993, C-27-2-02 Vol. 2, OTS archive.

${ }^{496}$ Rakiura Ngāi Tahu were also intimately involved in the negotiations regarding Whenua Hou and the Crown Titi Islands. Rakiura Ngāi Tahu were disappointed with the proposal for Whenua Hou and believed that the proposals should have allowed for greater Rakiura Ngāi Tahu control of the island. The Rakiura Titi Committee was the coordinating committee regarding the Titi Islands and O'Regan and the Ngāi Tahu Māori Trust Board consulted with the Committee during the negotiation process. The Rakiura Titi Committee gave its interim approval for the draft management structure deed for the Crown Titi Islands in mid-1993. But the Committee was split on the vesting of the Titi Islands. Some members of the Committee believed that the Islands should be vested locally rather than into Te Runanga o Ngāi Tahu. Eventually agreement was reached that the Islands would be vested in Te Runanga o Ngāi Tahu with local direct management of the Islands themselves: "Minutes of Meeting between Ngāi Tahu and Crown Negotiators," 1 July 1993 \& "Minutes of Meeting between Ngāi Tahu and Crown Negotiators,” 28 July 1993, both: C-27-2-02 Vol. 2, OTS archive. O’Regan to Graham, 18 January 1994 \& "Minutes of Meeting between Ngāi Tahu and Crown Negotiators," 26 January 1994, both: C27-2-02 Vol. 3, OTS archive.

${ }^{497}$ It is unclear what Forest \& Bird's immediate response was to the draft deed but in line with their opposition to all other aspects of the Ngāi Tahu settlement it was most likely negative. "Minutes of Meeting between Ngāi Tahu and Crown Negotiators," 1 July 1993; "Minutes of Meeting between Ngāi Tahu and Crown Negotiators," 28 July 1993; "Minutes of Meeting between Ngāi Tahu and Crown Negotiators," 6 October 1993, all: C-27-202 Vol. 2, OTS archive.
} 
Titi Islands proved partially successful as the Board narrowly provided its support for the proposals. Ngāi Tahu sought to expedite the transfer of the Crown Titi Islands and establish the Reserves Board at Whenua Hou following the Board’s approval, but Graham still required the Minister of Conservation's support. ${ }^{498}$ As the negotiations came to a halt in mid1994 the two parties began to explore a possible interim settlement. Ngāi Tahu wanted to include Whenua Hou and the Crown Titi Islands in the interim settlement, but the Minister of Conservation opposed its inclusion citing the narrow support of the Southland Conservation Board for the proposals. The Minister of Conservation was also concerned about the waiving of the marginal strip at the Crown Titi Islands. The Crown refused to include either the Crown Titi Islands or Whenua Hou in the November 1994 interim settlement since Ngāi Tahu's proposals for the two items of redress were still under consideration by the Crown. The Crown's position on Whenua Hou and the Crown Titi Islands contributed to the rejection of the interim settlement by Ngāi Tahu in late 1994, and the subsequent breakdown of the negotiations. ${ }^{499}$

When negotiations were recommencing in early 1996, the Crown explored some variations in the settlement offer regarding Whenua Hou and the Crown Titi Islands to obtain Ngāi Tahu’s approval. Substantial internal Crown debates developed during the recommencement process. Te Puni Kōkiri and DoC officials debated conservation issues and the potential for those issues to foster or endanger the development of goodwill between Crown and Ngāi Tahu negotiators. Comments by DoC officials on the Cabinet paper being developed in March 1996 reflected some of the reasons the first on account settlement was rejected so vigorously by Ngāi Tahu in November 1994. DoC wanted the Cabinet paper to

\footnotetext{
498 "Minutes of Meeting between Ngāi Tahu and Crown Negotiators," 8 June 1994, C-27-2-02 Vol. 3, OTS archive.

${ }^{499}$ O'Regan to ToWPU official 8, 8 August 1994; Graham to Cabinet Strategy Committee, "Ngāi Tahu onaccount settlement,” 24 August 1994; CAB (94) M 40/10, all C-27-2-02 Vol. 3, OTS archive.
} 
highlight the significant public opposition that was raised against the Whenua Hou and

Crown Titi proposals, and that they were only passed by a narrow majority by the Southland

Conservation Board. ${ }^{500}$ A TPK official commented:

We consider TPK should be involved in any inter-departmental discussions on these matters as our participation will assist in achieving a better outcome. For example, in the past we have contested several elements of the Crown's present negotiating position (ownership of pounamu, Whenua, Crown Titi Islands, Rarotoka including [the] foreshore and seabed) which are only now being contemplated as part of the compromises necessary to reach a settlement. ${ }^{501}$

While DoC's concerns about the Southland Conservation Board consultation process were included in the final Cabinet paper, the Cabinet paper also set out the limitations of the previous interim settlement offer of November $1994{ }^{502}$ OTS officials advocated for revised positions that reflected TPK and Ngāi Tahu's concerns.

At Whenua Hou, Ngāi Tahu sought equal representation on the Reserves Board and the development of transparent and explicit protocols between the Department of Conservation and Ngāi Tahu regarding visitation rights. For the Crown Titi Islands, Ngāi Tahu's request for the waiving of marginal strips was necessary to advance the negotiation process. The Whenua Hou proposal for Ngāi Tahu that was developed in the first half of 1996 in preparation for the formal recommencement of negotiations largely met the approval of Ngāi Tahu. In addition to equal representation on the Reserves Board that would be established to better manage Whenua Hou, a consultative group comprised of Rakiura Ngāi Tahu would be formed to provide advice to the Department of Conservation Regional Conservator on the issue of entry permits. The fee simple title of Crown Titi Islands without a marginal strip requirement was offered for return to Ngāi Tahu, but the Islands would still be

\footnotetext{
${ }^{500}$ DoC official 2 to OTS official 3, 20 March 1996, NE-12-027-00-02 Vol. 3.

501 TPK official 3 to OTS official 3, 20 March 1996 \& Graham to Cabinet Strategy Committee, "Ngāi Tahu: specific assets with conservation implications,” 31 March 1996, both: NE-12-027-00-02 Vol. 3.

${ }^{502}$ CSC (96) M 10/3a, b\&c, NE-12-027-00-02 Vol. 4, OTS archive.
} 
managed as a nature reserve. Ngāi Tahu sought sole management control of the Islands while the Crown wanted to remain involved in the management of the Islands. ${ }^{503}$

As the negotiations neared a Heads of Agreement in late September 1996, Ngāi Tahu proposed that the fee simple title of Whenua Hou would be transferred to Ngāi Tahu with immediate giftback to the Crown. Due to Crown opposition, the fee simple title would remain with the Crown, but Ngāi Tahu then sought an undertaking that if the Island were no longer required for conservation purposes it would pass to Ngāi Tahu. This was in effect a Right of First Refusal to Whenua Hou. The Crown remained in opposition to Ngāi Tahu’s proposal. The Crown's final offer was that instead of the establishment of a Reserves Board, a subcommittee of the Southland Conservation Board would be established in its place with equal representation between Rakiura Ngāi Tahu and the Southland Conservation Board. The Committee would also prepare a policy setting out the conditions under which the Minister of Conservation would grant permits for access to Whenua Hou. In exchange Ngāi Tahu would receive the fee simple title to the Crown Titi Islands and sole responsibility for the management of the Islands. ${ }^{504}$

When an agreement was finally reached on Whenua Hou and the Crown Titi Islands just before the 1996 election, the traditional conservation and sports recreation third-party interest opposition such as the Federated Mountain Clubs (FMC) and the Royal Forest \& Bird Society continued to oppose any settlement involving conservation areas. The President of Forest \& Bird, Kevin Smith, continued to express opposition to the transfer of the Crown Titi Islands. ${ }^{505}$ The Southland branch of Forest \& Bird expressed its concern with the allegedly

\footnotetext{
${ }^{503}$ OTS official 3 to DPMC, CLO, Treasury and DoC officials, 18 March 1996; Graham to Cabinet Strategy Committee Chair, "Ngāi Tahu: Specific assets with conservation implications," 31 March 1996, NE-12-027-0002 Vol. 3, OTS archive; Bolger to O’Regan, 22 April 1996, NE-12-027-00-02 Vol. 5, OTS archive.

${ }^{504}$ Goodall to Ngāi Tahu Negotiating Team, 19 September 1996, Vhi 52c (u), TRONT archive.

${ }^{505}$ Kevin Smith to Doug Kidd, 3 October 1996, Vhi 54 (f), TRONT archive.
} 
“speedy” negotiations underway between the Crown and Ngāi Tahu. Forest \& Bird opposed the proposed handover of the Crown Titi Islands and the creation of a separate conservation board sub-committee for Whenua Hou. Barbara Marshall of the FMC asked that neither the Crown Titi Islands nor Whenua Hou be used as redress despite the clear recommendations of the Waitangi Tribunal. ${ }^{506}$

The negotiations and settlement provisions regarding the Arahura River, Whenua Hou and the Crown Titi Islands were a product of the Waitangi Tribunal's specific findings and recommendations. Substantive negotiations took place over a number of years and were subject to numerous consultation processes with third-party conservation organisations. The Tribunal's recommendation that the Crown transfer the fee-simple title of a specific conservation area, the Crown Titi Islands, was effected. The Tribunal did not recommend the transfer of Whenua Hou, but Ngāi Tahu still sought the title to the Island in a "joint title" approach like the Australian arrangements at Uluru/Ayers Rock and late in the negotiation the transfer of title with immediate giftback to the Crown. Neither of Ngāi Tahu's propositions with regards to the title to Whenua Hou was accepted by the Crown. Nonetheless Ngāi Tahu was able to obtain a significant management role in the Whenua Hou Nature Reserve. The return of the Crown Titi Islands without the marginal strip traditionally required when the Crown disposes of land and with sole Ngāi Tahu control of the Islands reflected the measure of rangatiratanga that Ngāi Tahu had re-established around these important sites of cultural significance.

\footnotetext{
${ }^{506}$ Owen Cox to Graham, 27 August 1996, NE-18-027-00-01, OTS archive; CE Henderson to Graham, 4 September 1996, NE-18-027-00-01, OTS archive; Forest \& Bird, "Postpone Ngāi Tahu Settlement, Forest \& Bird Plea,” 1 October 1996, Vhi 53b (l), TRONT archive; Kevin Smith to Doug Kidd, 3 October 1996, Vhi 54 (f), TRONT archive. In a similar vein, PANZ claimed that access to climbing Aoraki would be completely banned under Ngāi Tahu control while Forest \& Bird argued that the government would be giving away the entire conservation estate in the South Island: PANZ, "Climbing MT Cook could be banned under secret deals with Ngāi Tahu," 1 October 1996, Vhi 53b (1), TRONT archive.
} 


\section{Part II: Waikato-Tainui}

\section{The gradual development and eventual establishment of Waikato-Tainui's land-bank}

The development of Waikato-Tainui’s land-bank took place over a much longer period than the relatively quick establishment of the Ngāi Tahu land-bank. During WaikatoTainui’s scoping negotiations in July and August 1989, a Treasury official drafted a Cabinet paper that would establish the first land-bank or "early warning system.” The Treasury official suggested a system under which the Tainui Māori Trust Board would be warned when the alienation of Crown land in the Waikato-Tainui rohe was proposed. The Trust Board would then have the opportunity to place the property in their land-bank for future use in a settlement. The draft Cabinet paper developed by the Treasury official was never finalised and sent to Cabinet. ${ }^{507}$ The litigation undertaken by the Tainui Māori Trust Board with regards to coal assets in their rohe in late August 1989 effectively caused a brief delay in negotiations. Presumably the delay was the reason the early warning system was not developed any further in the early scoping negotiations. ${ }^{508}$

After the Tainui Māori Trust Board’s victory in the Coalcorp case, Waikato-Tainui's negotiations with the Crown continued in March 1990 with Robert Mahuta and Justice Minister Bill Jeffries as respective lead negotiators. The continuing alienation of Crown land in the Waikato-Tainui rohe remained a significant concern for Waikato-Tainui negotiators. In a May 1990 report to the Core Group of Officials in the Crown Task Force on Treaty of Waitangi Issues, ToWPU officials stated that "restraint [in the alienation of Crown land] was considered necessary to comply with the view of the Court of Appeal in the Coalcorp case that any attempt to shut out in advance claims to surplus lands is not consistent with Treaty principles.” After the establishment of Ngāi Tahu's land-bank in early 1990, ToWPU

\footnotetext{
507 Treasury official 1 to ToWPU official 3, 7 August 1989, TC30 Vol. 6, OTS archive.

${ }^{508}$ Tainui Māori Trust Board v. Attorney General (1989); McCan, Whatiwhatihoe, 273-296.
} 
officials pressed Cabinet to put the land-bank system in place for Ngāi Tahu to the Tainui Māori Trust Board. ToWPU officials believed that the continuing alienation of Crown land had the potential to jeopardise the negotiations and potentially push Waikato-Tainui to reinitiate litigation to prevent the alienation of further Crown land. At the very least, the establishment of a land-bank would be construed as a gesture of good will from the Crown. ${ }^{509}$ Despite the recommendations of ToWPU, Cabinet refused to establish the early warning system and instead focused on developing the settlement offer that was rejected by WaikatoTainui later in 1990.

In the absence of any system by 1991 Waikato-Tainui negotiators and advisors turned to asking for written undertakings from the new National Minister of SOEs, Doug Kidd, and Minister of Justice Doug Graham that Crown assets should not be sold in the Waikato raupatu rohe. Before negotiations formally began with National, Waikato-Tainui’s legal advisor, Denese Henare, wrote repeatedly to warn Graham and the ToWPU Director about Crown properties that were offered for sale. ${ }^{510}$ While claimants should have been expending their time and energy on the task of negotiation, often Waikato-Tainui negotiators and advisors were forced to expend their limited resources ensuring that the Crown's asset base was not diminished any further.

Graham sought to institute a land-bank system for Waikato-Tainui and other large claimant groups such as Muriwhenua and Taranaki. Formal negotiations had recommenced between the Crown and Waikato-Tainui negotiators in November 1991 and by mid-1992 ToWPU officials began to develop Waikato-Tainui's land-bank. While Waikato-Tainui

\footnotetext{
${ }^{509}$ Minister of Justice to Chairperson, Core Group of Officials, Crown Task Force on Treaty of Waitangi Issues, "Sale of Crown lands within Tainui raupatu," May 1990, TC30 Vol. 8, OTS archive.

${ }^{510}$ Henare to Kidd, 5 June 1991, AAKW W5105 7812 26, Archives NZ; Henare to Graham \& Maurice McTigue, 8 November 1991, RC Vol 5, Box 8, W-T archives; Henare to McTigue, 13 November 1991, TC30 Vol. 16, OTS archive.
} 
appreciated the efforts being made by the Crown to develop an early warning system, the proposal still contained a presumption of sale which was not appropriate for Waikato-Tainui's land for land principle that no further Crown assets should be sold within the raupatu rohe. Waikato-Tainui attempted to include assets in their land-bank which were unavailable for Ngāi Tahu. ${ }^{511}$

Waikato-Tainui argued that as their total rohe was much smaller, the Crown would need to provide a greater diversity of assets. Waikato-Tainui wanted to include Crown Research Institute (CRI) land, Housing New Zealand (HNZ) properties, Area Health Boards and educational properties. In addition to the ability to include these lands in their land-bank, Waikato-Tainui requested that the Crown maintain its stock of HNZ properties in the rohe until negotiations were complete. ${ }^{512}$ Treasury did not agree that HNZ or Area Health Boards were Crown assets and was especially concerned about how the precedent of no net diminution would affect HNZ’s commercial operations. How would HNZ follow their directives which instructed them to sell all surplus lands? As a result of the smaller size of the Waikato-Tainui rohe, ToWPU officials also proposed that there be no cap on the WaikatoTainui land-bank but Treasury maintained that it was necessary for claimants to understand that the Crown's funds were not limitless. Treasury's final concern was that the Crown would be held financially responsible for deferred maintenance. Despite the negative experience of Waikato-Tainui with Hopuhopu, Treasury decided that claimants would have to receive the properties as is. In reaction to Treasury opposition, a ToWPU official responded that Waikato-Tainui “would have to have some kind of land-bank at some point.” Treasury

\footnotetext{
${ }^{511}$ Mahuta to Graham, 15 June 1992, TC 30 Vol. 23, OTS archive.

${ }^{512}$ Mahuta to Graham, 15 June 1992, RC Vol 11 1992, Box 11, W-T archives.
} 
replied that it wanted a separate Treasury comment in the land-bank paper, which aided in its eventual rejection in Cabinet in mid-1992. ${ }^{513}$

After ToWPU's failed attempts at establishing a land-bank for Waikato-Tainui in 1992, Graham sought to re-engage with Treasury, Cabinet and Waikato-Tainui over the issue in early 1993. Graham wrote to Mahuta to discuss what the cap for the Waikato-Tainui landbank might be. While any engagement was welcomed while the negotiations were essentially in hiatus, legal advisor Denese Henare wrote to Mahuta expressing her concern about Graham's request for a discussion regarding the cap for the land-bank. Although the development of the land-bank was welcomed by the Waikato-Tainui negotiators, Henare interpreted the development as the Crown approaching the issue "piece-meal." To Henare the land-bank was merely an instrument for preserving the Crown's capacity to provide reparations, not a part of the final settlement arrangement. At this point the right of first refusal had yet to be developed, so Henare was not correct in the long term but in the short term her frustration stemmed from the Crown's insistence on a cap for the land-bank. “The Waikato position is that we will have all you have got put into the land bank, which is effectively the 163,000 acres of properties within the Crown dossier.” There were also some significant concerns about receiving the lands on an "as is, where is" basis, especially as a result of the TMTB's negative experience with Hopuhopu. The goodwill established by the return of Hopuhopu had been tainted by the significant financial liabilities that the base carried upon transfer. Henare recommended that Mahuta discuss it privately with the Minister rather than a potentially “provocative letter” to ensure Graham was kept on side. ${ }^{514}$

\footnotetext{
513 Treasury official 9 to ToWPU official 4, 21 July 1992, TC30 Vol. 24, OTS archive; Minister of Justice to Cabinet Strategy Committee, “Proposals for an Early Waikato System for Tainui,” 23 July 1992, TC30 Vol. 24 , OTS archive. I have not been able to locate the Cabinet paper that rejects the proposals, but the system is not established until 1993 so it is clear Cabinet rejected the proposals earlier in 1992.

${ }^{514}$ Henare to Mahuta, 13 April 1993, RC Vol 30 1993, Box 11, W-T archives.
} 
ToWPU recommended to Cabinet that the cap for the Waikato-Tainui land-bank be set at \$35 million while Treasury advocated that it should be set at \$16 million to ensure funding was also made available for other Treaty claim settlements and land-banks. Unusually, ToWPU won out in the end. In contrast to Ngāi Tahu's land-bank, the properties also would have to be the first used in any future settlement. While it was clear that WaikatoTainui wanted all of the Crown's remaining land placed in the land-bank, Mahuta nonetheless wrote a thankful letter to the Crown. In early May 1993 Graham replied that he was happy to inform Mahuta that the land-bank was formerly established and had a \$35 million cap, with one minor rider that was symbolic of the gulf between the power of each party in the negotiation: "The Crown reserves the right to cancel the land bank and free the properties for sale." 515

One of the first assets available for Waikato-Tainui’s land-bank were 200 Electricity Corporation New Zealand (ECNZ) houses located in Meremere and Huntly. These ECNZ properties had protection memorials on their title. ${ }^{516}$ Waikato-Tainui advisors cautioned ECNZ that they should not proceed with the auction to sell the properties but ECNZ did not heed their warnings. After receiving no bids ECNZ offered the properties to the Crown for inclusion in the Waikato-Tainui land-bank. ${ }^{517}$ The land-banking of the ECNZ surplus assets was supported by Treasury but only because of the advanced nature of Waikato-Tainui's negotiations with the Crown. Some officials from Treasury attempted to argue that because

\footnotetext{
${ }^{515}$ CAB (93) 259; CAB (93) M 15/26; TOW (93) 6: AAKW W5105 7812 22, Archives NZ; Graham to Mahuta, 12 May 1993, RC Vol 30 1993, Box 11, W-T archive; Mahuta to Thomas, 20 May 1993, RC Vol 31, Box 12, W-T archive.

${ }^{516}$ Section 27B of the Treaty of Waitangi (State Enterprises) Act 1988 stated that if the Tribunal found that specific SOE land had been acquired in breach of the principles of the Treaty of Waitangi it could order the government to reacquire the land at market value and return it to the Māori claimants: Treaty of Waitangi (State Enterprises) Act 1988, Section 27B.

${ }^{517}$ Reuben Wharawhara, "Board Warns of land claims on ECNZ houses,” Waikato Times, 7 August 1993; Mahuta to ToWPU official 4, 21 June 1993; ToWPU official 4 to John Te Maru, 17 August 1993, all: RC Vol 31, Box 12, W-T archives.
} 
the bulk purchase had resulted in the Crown purchasing at half the value, the Crown should receive some kind of compensation. ToWPU officials were clearly unimpressed by the idea.

Such an approach is inconsistent with the principles for land banking and with the proposed operation of the Treaty of Waitangi Settlement Fund. The cap on the land bank provides incentives for the claimants to select properties up to its value on the basis of the sum of the prices paid for those properties. Claimants carry the risk that the properties will reduce in value while in the land bank. The Crown loses nothing if the properties increase in value. We consider to impose a charge against the cap on the land bank of any more than the price paid by the Crown would be an act of bad faith. ${ }^{518}$

ToWPU officials obviously felt strongly about the issue and successfully countered Treasury.

Once the land-bank was established the TMTB slowly evaluated surplus Crown properties for inclusion in the land-bank. Graham complained in a letter to Mahuta regarding the delays in evaluating properties. Mahuta responded that the Crown had provided incomplete information with regards to the extent of the Crown's asset base in the WaikatoTainui rohe. In June 1993 the Crown enquired whether Waikato-Tainui sought to add certain properties into the land-bank. Mahuta wrote a frustrated reply to ToWPU officials:

Given the current state of confusion, maybe all housing stock should go into the Land-bank before we are pestered to make decisions based on scanty information...As you can see from the tenor of this note, I came out of my meeting with the Minister feeling somewhat annoyed that matters have not really progressed very far. If the Crown has no intention to settle with Waikato then perhaps that needs to be said so that we can all reassess our positions. We are incurring too much time, energy and costs on non-fruitful endeavours. ${ }^{519}$

In 1994 Mahuta continued this argument and emphasised the Crown's lack of funding for evaluating surplus properties for land-banking which had inhibited the TMTB's other operations. Mahuta added that it was "important from the TMTB's perspective (and in the longer term that of the Crown) to ensure it is assets rather than liabilities which are being land-banked. The Hopuhopu and Te Rapa experiences are a constant reminder of this.

\footnotetext{
${ }^{518}$ ToWPU official 4 to Treasury official 9, 11 October 1993, AAKW W5105 7812 22, Archives NZ.

${ }^{519}$ Mahuta to ToWPU official 4, 21 June 1993, RC Vol 31, Box 12, W-T archives.
} 
Accordingly, prudence suggests that the Board must and will continue to be careful in its scrutiny of properties to be transferred." ${ }^{520}$ Mahuta noted that without any type of agreement on the implementation of the settlement the "exercise has something of the ring of shuffling paper from one government department to another.” Mahuta stated that it was important to Waikato-Tainui, and from Mahuta's point of view also for the Crown, that properties with liabilities not be used in the settlement. This would simply represent a repetition of history similar to the return of lands by the Compensation Court in the nineteenth century after the original confiscation of land when mainly unusable land was returned. ${ }^{521}$

As the Crown continued to raise concerns with the delays in Waikato-Tainui's evaluation of properties, Mahuta continued to express his concern with the quality of Crown properties offered for inclusion. Graham stressed that Waikato-Tainui did not have to approve each and every property. Henare pointed out that Waikato-Tainui’s concerns with Graham’s recommendation was the potential for an unsuccessful negotiation in which Waikato-Tainui acquiesces to the disposal of land. Graham countered that it was not only surplus properties which could be used in any settlement, but any properties in the Crown's dossier. This changed the situation as it was different from anything discussed previously. Mahuta took this point one step further and asked whether non-Crown lands would be available for purchase with settlement funds, which Graham confirmed. This was necessary because of the significant liabilities which most properties in the Crown dossier carried. ${ }^{522}$

\footnotetext{
${ }^{520}$ Mahuta to Graham, 8 March 1994, AAKW W5105 7812 22, Archives NZ/RC Vol 33, Box 13, W-T archives.

${ }^{521}$ Mahuta to Graham, 8 March 1993, RC Vol 33, Box 13, W-T archives; Mahuta diary note, 10 March 1993, RC Vol 33, Box 13, W-T archives; Danny Keenan, Wars without end (Auckland: Penguin, 2009), 264-282; Craig Innes and James Mitchell, "Alienation of Māori granted lands within Te Rohe Pōtae Parish extension, 1863-2011,” Report Commissioned by the Waitangi Tribunal (Wai 898, \#A30), 2013.

522 Solomon and Henare memoranda, 14 April 1994, RC Vol 33, Box 13, W-T archives; ToWPU, "Meeting between Crown and Waikato negotiators,” 14 April 1994, AAKW W5105 7812 22, Archives NZ.
} 
Issues with information regarding the Crown's asset base continued as the negotiations neared completion and echoed some of the earlier frustrations of Waikato-Tainui negotiators. Certain properties sought by Waikato-Tainui were initially restricted from transfer, as the Crown began to decide which properties would need to remain in Crown ownership. In October 1994 Waikato-Tainui had received the latest schedule of Crown assets. The schedule contained properties which the Crown was not initially willing to transfer as part of a settlement such as the land underneath the Hamilton Courthouse, the University of Waikato, most primary schools in the Hamilton area, Waikato Hospital, and the Whatawhata and Ruakura Research Stations. Waikato-Tainui advisor John Te Maru commented, “Unless the position has changed, we might expect another schedule soon with even less lands on it or some form of Crown advice that certain properties are no longer available.”523 Although Graham previously stated to Mahuta that all lands in Crown ownership were available to form a part of the Waikato-Tainui settlement, there were some limits. Waikato-Tainui successfully managed to obtain land under some primary schools, the Hamilton Courthouse, the University of Waikato, and Ruakura and Whatawhata Research Stations, but not Waikato Hospital. All of the areas that were transferred were subsequently leased back to the Crown or its agencies. ${ }^{524}$

\section{Waikato-Tainui and the return of land}

The return of land was a central component in the Waikato-Tainui negotiation process. While some Crown lands were offered for return, lands from the DoC estate were completely excluded. Waikato -Tainui was focused on not only the return of land, but also ensuring the land that was transferred could be retained. Waikato-Tainui negotiators and

\footnotetext{
${ }^{523}$ Wheeler to Mahuta, 15 September 1994, RC Vol 34, Box 13, W-T archives, 1; Te Maru to Mahuta, 15 September 1994, RC Vol 34, Box 13, W-T archives, 2.

${ }^{524}$ Waikato-Tainui Raupatu Deed of Settlement, 22 May 1995, 10-15, Attachment 3.
} 
advisors advocated for the return of land under customary title, rather than the fee simple title that was proposed, and also sought the return of lands that were not subject to marginal strips. Waikato-Tainui were concerned that their land settlement would not affect their claims to the Waikato River and West Coast Harbours that had been separated early in the negotiations. These issues reflected Waikato-Tainui's overriding concerns with the return and retention of land under circumstances that would enhance the rangatiratanga of the iwi in the Waikato.

\section{Waikato-Tainui and the return of DoC land}

The return of sites of cultural significance did not occur in Waikato-Tainui’s settlement. As a result DoC's involvement in the Waikato-Tainui negotiations was limited since the settlement would only address issues regarding the confiscation of land, rather than specific conservation sites. Nonetheless Waikato-Tainui sought land from the conservation estate or if the return of DoC land was not possible, then a co-management role in DoC areas. ${ }^{525}$ Late in the negotiations Mahuta attempted to have full title to the DoC estate included in the settlement. Those DoC lands would then be leased back to the Crown at peppercorn rentals which would be reviewed every 25 years. Mahuta stated in a letter to Graham: "It is not the intention to develop Conservation lands. We are however, interested in joint management of the estate and the jobs or training opportunities that might arise. Such an arrangement would satisfy our 'Land for Land' principle while at the same time meet the Crown's desire to maintain the lands for public use and access.” As Ngāi Tahu had also done during its negotiations, Waikato-Tainui negotiators stressed that international examples of comanagement regimes in Australia and Canada had provided precedents and would be valuable to use in the New Zealand context. ${ }^{526}$ Furthermore, Waikato-Tainui condemned the

\footnotetext{
${ }^{525}$ Wayne Taitoko to Mahuta, 7 October 1994, RC1, Correspondence Vol 35, Box 14, W-T archives.

${ }^{526}$ Stacey Anne Shortall, “Aboriginal self-government in Aotearoa-New Zealand: a view through the Canadian lens,” Thesis (LL.M.), University of Alberta, 1996.
} 
Crown's own record of conservation and alluded to the poor job it had done in the Waikato region to that date. Waikato-Tainui stressed that the iwi would work with involved stakeholders such as conservation boards and regional and local authorities and would strive to enhance the conservation value of the lands as well as the public's access to them. ${ }^{527}$ Graham stated that the conservation estate was not available and instead offered WaikatoTainui representation on the Waikato Conservation Board. ${ }^{528}$ The issue of the DoC estate was consistently brought up during the consultation process by both supporters and opponents of Mahuta within Waikato-Tainui. It was a very important issue for the iwi that could have derailed the settlement because Waikato-Tainui wanted an increased kaitiaki role in the overall management of the DoC estate. ${ }^{529}$

The DoC position was very firm although it was challenged by ToWPU. The lead ToWPU official on the Waikato-Tainui negotiations tried to work with DoC, but they maintained their opposition. The Director-General of DoC replied to ToWPU inquiries regarding the use of the conservation estate in either the transfer of land or co-management, that there were significant and wide ranging implications if any of the conservation estate were transferred to Waikato-Tainui, even if DoC lands were immediately gifted back. The Director-General referred to the difficulties involved in the return of Mount Hikurangi to Ngati Porou. Issues regarding public access to Mount Hikurangi following its return to Ngati Porou made the Director-General apprehensive. He pointed to the spectre of co-management with Māori claimants and questioned whether the Crown or public was ready for such a

\footnotetext{
${ }^{527}$ Mahuta to Graham, 4 November 1994, TC30 Vol. 39, OTS archive; Solomon to Mahuta, 7 November 1994, RC1, Correspondence Vol 36, Box 14, W-T archives.

528 "Meeting between Crown and Waikato negotiators," 26 October 1994, RC1, Correspondence Vol 35, October 1994, Box 14, W-T archives; "Meeting between Crown and Waikato negotiators," 26 October 1994, TC30 Vol. 38, OTS archive, 2; Mahuta to Graham, 26 October 1994, TC30 Vol. 38, OTS archive; Graham to Mahuta, 27 October 1994, RC1, Correspondence Vol 35, October 1994, Box 14, W-T archives.

${ }^{529}$ Wayne Taitoko to Mahuta, 7 October 1994, RC1, Correspondence Vol 35, Box 14, W-T archives; Mahuta to TMTB Maraes, 1 November 1994 and “Hui-a-Iwi,” 13 November 1994, both: RC1, Correspondence Vol 36, Box 14, W-T archives.
} 
change. He also referred to the potential negative effect on "investment security for businesses.” ${ }^{530}$ DoC’s position in Cabinet prevailed, and there was no involvement from DoC in Waikato-Tainui’s settlement. ${ }^{531}$

\section{Waikato-Tainui's desire for customary title}

The legal form in which lands would be returned also troubled Waikato-Tainui negotiators and advisors. Legal advisor Denese Henare felt that special legislation specifically vesting returned land into Waikato-Tainui was necessary. When the parties were approaching a Heads of Agreement in late 1994 and it became apparent that further lands in addition to Hopuhopu and Te Rapa would be transferred, Henare again pressed for special arrangements to govern the return of land to Waikato-Tainui. Henare corresponded with ToWPU officials about the possibility of the return of land under customary title that would not be governed by the provisions of the Public Works Act. Henare feared that WaikatoTainui would not have absolute control over its land if it was subject to possible future confiscation of land through administrative means such as public works takings. ToWPU officials had raised the issue of customary title with Graham but he did not believe the concept could be used. Graham repeated his opposition publically at a February 1995 academic conference on Treaty settlements held in Wellington. Henare had wanted to engage in formulating relationships between rangatiratanga and the statutory and regulatory powers of central and local government, but the traditional aversion by the New Zealand government to any delegation of sovereignty was paramount. ${ }^{532}$

\footnotetext{
${ }^{530}$ Director-General of DoC to ToWPU official 4, 18 November 1994, TC30 Vol. 40, OTS archive.

${ }^{531}$ CAB (94) M 49/30, TC30 Vol. 42, OTS archive.

532 ToWPU official 4, "Waikato negotiations," 13 December 1994, TC30 Vol. 41; ToWPU official 4 to Henare, 3 January 1995, RC1, Correspondence Vol 39, Mar - Apr 1995, Box 17, W-T archives; Shane Solomon, "Notes from conference," 9-10 February 1995, RC1, Correspondence SS, Jan - Feb 1995, Box 34, W-T archives; Doug Graham, “Address by the Minister in Charge of Treaty of Waitangi negotiations,” in Geoff McLay (ed.) Unfinished Business (Wellington: NZ Institute of Advanced Legal Studies, 1995), 141-147.
} 
Although Graham had rejected the suggestion of placing the land being returned to Waikato-Tainui in a form of tribal or customary title, Henare and Waikato-Tainui legal advisor Shane Solomon still sought ways to instil into the proposed legislation the special spirit and intent of this particular transfer of land from the Crown. Solomon looked to the developments in Australia with regards to native title at both the federal and state levels for inspiration but admitted that the Crown would probably oppose such proposals. In terms of conservation land Waikato-Tainui negotiators had fought for the Australian "Uluru” model, but the Crown rejected the model. The Crown offered a reserved position on the Waikato Conservation Board. Solomon wanted the legislation that governed the returned land to reflect the tenure of the land as it was in 1863--something Solomon admitted was very difficult.

What is being sought there is the nature of the 'ownership' back in 1863-65. There should be no confusion that we are seeking the lands to be returned in the state they were in back then - ie the University lands to be returned with no improvements. The 'ownership' issue relates to the vesting of the lands under the Kingiitanga, thus the compulsory taking of those lands by the Crown. It also relates to the tribal interest in the lands. Prior to the wars and confiscations, lands vested in Te Wherowhero (subsequently reaffirmed through the years). The Confiscations removed lands away from both the kingiitanga and therefore the Tribe. Today, the return of the lands must benefit all of the tribe who suffered, not just those who are fortunate enough to have Crown owned lands left to settle the grievance. The vast majority are not so fortunate. ${ }^{533}$

The debates over the form in which land would be returned and to which organisation the land would be returned remained pressing throughout the negotiation process. During a February 1995 meeting with Waikato-Tainui advisors, Crown officials expressed their concern that if certain lands were rendered inalienable, it would affect the iwi's commercial flexibility following settlement. Waikato-Tainui financial advisors countered that although it would not be possible to mortgage inalienable land, the income from valuable leases could still be mortgaged. Waikato-Tainui advisors stated that the inalienable status of the land

${ }^{533}$ Solomon to Henare, 9 April 1995, RC Mar - Apr 1995, (SS) Box 35, W-T archives. 
provided comfort to the people that the returned lands would remain in the ownership of the iwi. $^{534}$

Mahuta also discussed the issue of a special title over lands returned with Graham directly during the period of negotiations between the signing of the Heads of Agreement in December 1994 and the Deed of Settlement in May 1995. After consideration by Graham, he maintained that land could be put into Te Wherowhero title as Hopuhopu and Te Rapa were, but that the land would still be in fee simple title, not any kind of "customary" title. Mahuta also was concerned about other land issues - the imposition by the Crown of marginal strips, and the desire by Waikato-Tainui to maintain the protective Treaty of Waitangi (State Enterprises) Act 1988 memorials on land along the Waikato River. ${ }^{535}$

\section{Marginal strips}

Waikato-Tainui's concerns with the manner in which land was returned led to Waikato-Tainui negotiators expressing their reservation with the return of land accompanied by marginal strips. Ngāi Tahu had felt that the imposition of marginal strips was another form of land alienation and Waikato-Tainui had similar concerns. Waikato-Tainui negotiators viewed marginal strips as another form of confiscation. The Crown was adamant that marginal strips would remain adjacent to former SOE lands along the river and foreshore, even after the protection memorials were lifted and the land possibly transferred to WaikatoTainui. OTS explained to Waikato-Tainui legal advisor Denese Henare that when the lands were first transferred to a SOE a marginal strip was imposed. The marginal strip would remain even after the land was disposed of privately by the SOE or via transfer to WaikatoTainui in any Treaty settlement. OTS stated that for other non-SOE lands the Crown still

\footnotetext{
534 "Meeting between Crown officials and Tainui advisors,"16 February 1995, RC Jan-Feb, Box 16, W-T archives and NE-12-030-00-35, OTS archive.

${ }^{535}$ Mahuta, “Meeting notes”, 14 April 1995, RC Vol 39, Mar - Apr 1995, Box 17, W-T archives
} 
retained the right to create a marginal strip whenever it disposed of land: "[M]arginal strips will be imposed, where relevant, when the Crown transfers land to [Waikato-]Tainui under the settlement." 536

The Waikato-Tainui opposition to marginal strips was so strong that the Deed of Settlement noted Waikato-Tainui's concerns. The Crown would maintain its power to retain and create marginal strips, but it agreed to record Waikato-Tainui's dissent. Section 5.4.3 of the Deed of Settlement stated: “That the Crown recognises that the issue of the creation of marginal strips on land to be transferred to the Land Holding Trustee is of serious concern to Waikato.” The settlement clause noted further that "the Crown acknowledges that Waikato intend to advance their concerns about the creation of marginal strips to the Minister of Conservation." 537 Waikato-Tainui continued to express their opposition to the imposition and retention of marginal strips during the Māori Affairs Select Committee Hearings before legislation was passed in November $1995 .{ }^{538}$ Waikato-Tainui were unsuccessful in advancing their concerns about the creation of marginal strips with the Minister of Conservation, and the issue would remain to be negotiated in Waikato-Tainui's Waikato River Treaty Settlement. ${ }^{539}$

\section{The removal of protection memorials on SOE lands along the Waikato River}

Another concern regarding the return of land for Waikato-Tainui negotiators was the separation of their land claim from Waikato-Tainui claims to the Waikato River and the three West Coast Harbours: Aotea, Kawhia and Whaingaroa (Raglan). The Crown wanted to have

\footnotetext{
${ }^{536}$ OTS Director to Henare, 3 April 1995, RC1, Correspondence March-April 1995 (SS) Box 37, W-T archives; Shane Solomon, “Telephone Conference,” 18 May 1995; Mahuta, "Notes on Draft Deed of Settlement,” 18 May 1995, RC1, Correspondence May 1995 Vol 40, Box 18, W-T archives.

${ }^{537}$ Waikato-Tainui Raupatu Deed of Settlement, 22 May 1995, Section 5.4.3.

538 "Waikato-Tainui Raupatu Claims Settlement Bill: Submissions on behalf of Waikato-Tainui," 25 August 1995, RC1, Correspondence June-September 1995 Vol 41 Box 19, W-T archives.

${ }^{539}$ Office of Treaty Settlements and the Ministry for the Environment, "Initial Departmental Briefing on the Waikato-Tainui Raupatu Claims (Waikato River) Settlement Bill,” 9 February 2009, http://www.parliament.nz/resource/0000095966.
} 
the Treaty of Waitangi (State Enterprises) Act 1988 protection memorials removed from State Owned Enterprises (SOE) lands along the Waikato River. ${ }^{540}$ Waikato-Tainui were concerned that their claim to the Waikato River was unjustly being affected by their land claim. Waikato-Tainui stated that retaining the memorials on river-side SOE properties was integral to the river and harbours claim, but the Crown contended that the memorials would be removed from the titles of SOE lands along the river by their land settlement. WaikatoTainui felt that the rangatiratanga of their river and harbours claim was being challanged by the Crown. ${ }^{541}$ Late in the negotiation process, only weeks before the signing of the Deed of Settlement, Mahuta requested that the memorials remain on the SOE properties along the Waikato River but Graham refused. Despite Waikato-Tainui’s objections, Graham stated that the memorials would be removed from the SOE properties along the river. ${ }^{542}$ The Crown's position on the memorials for the river-side SOE properties led to further Waikato-Tainui concerns about their continuing Treaty of Waitangi rights to the river and harbours.

Despite Graham’s public assertions that settlements were intended to fulfil the Crown's obligations under the Treaty of Waitangi rather than erase or undermine them, Waikato-Tainui negotiators still wanted to ensure that the Crown's obligations under the Treaty of Waitangi continued after settlement. ${ }^{543}$ Waikato-Tainui felt that their land-based raupatu settlement would only extinguish Waikato-Tainui's Treaty of Waitangi rights in relation to the grievance of raupatu. Waikato-Tainui legal advisors wrote to ToWPU officials:

\footnotetext{
${ }^{540}$ CLO official 4 to ToWPU official 4, 9 December 1994, TC30 Vol. 41, OTS archive.

${ }^{541}$ The CLO was worried that the inclusion of the term rangātiratanga in the legislation would suggest that "that the exercise of raNgātiratanga enables a future claim to be made over the raupatu lands" but OTS tried to assure CLO that was not the case: CLO official 4 to ToWPU official 4, 10 March 1995, NE-12-030-00-35, OTS archive, 4.

${ }^{542}$ Treasury official 5 to Bill Birch, "Waikato-Tainui: Update on Heads of Agreement and expected progress from here,”20 January 1995, NE 10-030-00-02 pt.1, OTS archive; Tom Moke to Mahuta, 8 March 1995, RC Vol 39, Mar - Apr 1995, Box 17, W-T archives

${ }^{543}$ Doug Graham, “Address by the Minister in Charge of Treaty of Waitangi negotiations,” 141-147.
} 
This settlement is a limited recognition of the Crown's obligations by way of redress (the return of land) for the specific injustice of the Raupatu, and those special rights (the rangatiratanga of Waikato under the Treaty) are not, and must not, be affected by this Settlement. The danger to Waikato of not making specific reference in this Deed to the rangatiratanga of Waikato under the Treaty is that Waikato is open to an argument, at some time in the future, that this Settlement is a settlement of Waikato's rangatiratanga, that Waikato has accepted a position which limits Waikato's rangatiratanga to a return of land. ${ }^{544}$

The issue of finality was still a large concern for Waikato even though the river and harbours had been excluded from their claim. Mahuta stressed to Graham in an early May 1995 meeting that the issue of the Crown's affirmation of Waikato-Tainui's rangatiratanga, especially in relation to Waikato-Tainui claims to the Waikato River and West Coast Harbours, had repeatedly been raised at consultation hui and that it was important to whether or not the settlement was accepted. In response to concerns about rangatiratanga rights, the Crown had amended the draft final deed of settlement to specifically state that the settlement would not diminish the Treaty of Waitangi or any of its articles but Mahuta stressed that this did not go far enough for Waikato-Tainui negotiators. ${ }^{545}$

The inclusion of the direct reference to rangatiratanga rights remained a problem even after the Deed of Settlement was signed on 22 May 1995, as discussions occurred in July 1995 just before the first draft of the legislation was introduced to Parliament. WaikatoTainui legal advisor Gerard Brown questioned why the inclusion of rangatiratanga rights was unacceptable to the Minister? Crown officials replied, much as they did to Ngāi Tahu when they were negotiating with the Crown over the development of their legal personality, that the term was undefined and that it would "introduce uncertainty into the Deed of Settlement." Eventually the Crown agreed during the meeting to include the reference to rangatiratanga

\footnotetext{
${ }^{544}$ Gerard Brown to Waikato negotiators, RC1, 1 May 1995, RC Apr - May 1995, (SS) Box 36, W-T archives, 1.

${ }^{545}$ ToWPU official 4 to Gerard Brown, 3 May 1995, RC1, Correspondence May 1995 Vol 40 Box 18, W-T archives; Solomon to Te Maru, 3 May 1995, RC1, Correspondence May 1995, (SS) Box 38, W-T archives; Mahuta to Graham, 4 May 1995, AAKW W5105 7812 23, Archives NZ.

${ }^{546}$ OTS official 4 to Graham, 10 July 1995, AAKW W5105 7812 22, Archives NZ.
} 
rights as a part of the detailing of the Treaty of Waitangi at the beginning of the settlement legislation. Nonetheless the first draft of the legislation contained the Treaty of Waitangi only in English in the preamble and thus there was no direct reference to rangatiratanga. The final legislation contained the Treaty of Waitangi in both English and Māori. A direct reference to rangatiratanga and Waikato-Tainui's claims to the River remained, even if the protection memorials on the titles of lands across the River did not. ${ }^{547}$

\section{The effect of previous owners of Crown land on the return of land to Waikato-Tainui: Te Rapa Airbase and Ohinewai Coalcorp lands}

The return of land to Waikato-Tainui was largely governed by the Crown's control of the process for retaining land for future settlement (land-banks), and the legal form in which land would be returned, but it was also affected by third-parties. Although Māori claimants such as Waikato-Tainui sought the return of land, former non-Māori land owners at times also sought the return of some of the same land that Waikato-Tainui were seeking. Under the Public Works Act 1981 the Crown had the power to acquire or take land for a wide variety of purposes. ${ }^{548}$ When land taken under the Public Works Act was no longer required for a public purpose, Section 40 of the Act provided an offer-back mechanism to the previous owner for purchase. ${ }^{549}$ The offer-back rights for previous land owners established by Section 40 were curtailed by Section 24(4) of the State Owned Enterprises Act 1986, which stated that Section 40 of Public Works Act 1981 would not apply to land transferred from the Crown to a State Owned Enterprise (SOE). ${ }^{550}$ Following the landmark NZMC victory in the Court of Appeal

\footnotetext{
${ }^{547}$ Henare to Solomon, 10 May 1995, RC1, Correspondence May 1995, (SS) Box 37, W-T archives; Niwa Nuri \& Solomon to Mahuta, 5 May 1995, RC1, Correspondence May 1995 Vol 40, Box 18, W-T archives.

${ }^{548}$ A recurring theme in Māori claims to the Waitangi Tribunal (and subsequent Waitangi Tribunal Reports) has been the compulsory acquisition of Māori land for public purposes under various Public Works legislation from the signing of the Treaty of Waitangi to the present day: Cathy Marr, Public Works Takings of Māori Land: 1840-1981, Rangahaua Whanui National Theme G (Wellington: Waitangi Tribunal, 1997).

${ }^{549}$ Public Works Act 1981, Section 40.

${ }^{550}$ State Owned Enterprises Act 1986, Section 24(4).
} 
which led to the Treaty of Waitangi (State Enterprises) Act 1988, the offer-back rights for previous land owners were further reduced. The Treaty of Waitangi (State Enterprises) Act 1988 inserted into the Treaty of Waitangi Act 1975 Section 8A, which provided a legislative framework for the Waitangi Tribunal to making binding orders for the Crown to transfer SOE lands claims to “the Māori or group of Māori” for particular well-founded claims. Under Section 8A(5) of the Treaty of Waitangi Act 1975, Section 40 of the Public Works Act 1981 did not apply. ${ }^{551}$

The debates within the Crown regarding the rights of previous owners of Crown land obtained under the Public Works Act 1981 began in 1992 when discussion took place over the return of Te Rapa airbase to Waikato-Tainui. Officials at ToWPU discussed with Department of Survey Lands and Information (DoSLI) and CLO officials whether land earmarked for the resolution of Treaty of Waitangi grievances had to be offered back to its previous owners first. ${ }^{552}$ DoSLI officials provided a number of legislative options such as the State Owned Enterprises Act 1986 Section 24(4), and the Treaty of Waitangi Act Section 8A(5) to circumvent the offer-back. DoSLI officials stated that the Crown could treat the land used for settlements as a public work, simply stating that Section 40 offer-back procedures did not apply to land which the government required for the resolution of Waikato-Tainui's claim. The Crown could also designate Crown owned land that was required for the settlement as exempted from the offer-back process. ${ }^{553}$

The Te Rapa airbase land had previously been owned by the Livingstone Family and they were offered back the land according to the Public Works Act in mid-1992. ${ }^{554}$ Initially

\footnotetext{
${ }^{551}$ Treaty of Waitangi Act 1975, Section 8(5); Treaty of Waitangi (State Enterprises) Act 1988, Section 4. 552 ToWPU official 4 to DoSLI official 4, 28 May 1992, TC30 Volume 23; ToWPU official 4 to CLO official 4, 29 July 1992, TC30 Volume 25: both OTS archive.

${ }^{553}$ DoSLI official 4 to ToWPU official 4, 21 July 1992, TC30 Volume 24, OTS archive.

554 “Base due to return to Tainui,” Waikato Times, 28 November 1992, TC30 Vol. 26, OTS archive.
} 
there were concerns expressed to ToWPU officials that a private developer would purchase the land from the Livingstone Family. ${ }^{555}$ In October 1992 a DoSLI official wrote to ToWPU that the Livingstone Family declined to purchase the Te Rapa airbase and that it would be purchased for immediate transfer to Waikato-Tainui as a partial settlement of its claims. ${ }^{556}$ Nonetheless in August 1993 a ToWPU official stated in a memorandum that the Tainui Māori Trust Board (with Crown funding) had purchased the land from the Livingstone Family. ${ }^{557}$ It is unclear how those negotiations took place and who precisely was involved but it presumably included representatives from ToWPU, the Tainui Māori Trust Board and the Livingstone Family. After the transfer of Te Rapa, no further lands were transferred to Waikato-Tainui before the signing of the Heads of Agreement.

As Waikato-Tainui and the Crown were nearing a Heads of Agreement, former owners of land taken under the Public Works Act affected the return of land in WaikatoTainui's settlement. The previous private land owners of some Crown land in the WaikatoTainui area felt that despite the provisions in the State Owned Enterprises Act 1986 and the Treaty of Waitangi Act 1975, before Crown land was offered to Waikato-Tainui it should have been offered back for purchase to the previous owner.

Originally ten farmers at Ohinewai and Meremere had their lands taken under the Public Works Act for a coal mine and power station during the 1970s and early 1980s. The assets from the government's State Coal Mines department were transferred to the newly established State Owned Enterprise Coal Corporation (or Coalcorp) in $1987 .{ }^{558}$ The State Owned Enterprises Act 1986 contained an amendment to the Coal Mines Act 1979 that

\footnotetext{
555 “Tainui Māori Trust Board meeting,” 4 July 1992, RC Vol 11 1992, Box 11, W-T archive; Derek Burns to Graham, 6 August 1992, TC30 Vol. 25, OTS archive; Mahuta to Henare, 22 October 1992, RC Vol 29, Box 11, W-T archive.

${ }^{556}$ DoSLI official 4 to ToWPU official 4, 12 November 1992, TC30 Vol. 26, OTS archive.

${ }^{557}$ ToWPU official 4 to Te Maru, 5 August 1993, RC Vol 31, Box 12, W-T archive.

${ }^{558}$ McCan, Whatiwhatihoe, 252.
} 
provided Ministerial discretion to dispose of lands. ${ }^{559}$ The Crown land at Ohinewai was not transferred to Coalcorp under Coalcorp’s 1988 Sale and Purchase Agreement because Coalcorp considered the land surplus to its requirements at that time. However, Coalcorp retained an unconditional option to purchase the land from the Crown under the 1988 Agreement. Even though it did not purchase the land Coalcorp still managed the land and negotiated any disposals or sales. In this strange sense the land was subject to the StateOwned Enterprises Act 1986, even though ownership was not transferred to Coalcorp. In 1988 Coalcorp initiated the first steps towards offering some Ohinewai properties back to the landowners pursuant to Section 40 of the Public Works Act. Some of the land was sold back to four out of ten of the former landowners. ${ }^{560}$ However, before the offer-back procedures were instituted for all of the surplus lands, the Tainui Māori Trust Board was granted an injunction by the Court of Appeal in 1989 as result of Tainui Mãori Trust Board v. AttorneyGeneral. Amongst other things, this prevented the sale of Coalcorp land (including land it managed) which was subject to the Waikato-Tainui raupatu claim. ${ }^{561}$

On 30 June 1994 Coalcorp gave notice to the former landowners under the 1988 Purchase and Sale Agreement that it wished to exercise its option to purchase all the Ohinewai land. Given the on-going negotiations with Waikato-Tainui at that time, the exercise of the option was deferred pending resolution of the negotiations. ${ }^{562}$ While the negotiations were nearing the Heads of Agreement that was signed in December 1994, two of the former land owners, the Levin Farm Settlement Trust and August Deane, initiated legal proceedings seeking to have the Section 40 offer-back procedures under the Public Works

\footnotetext{
${ }^{559}$ State-Owned Enterprises Act 1986, Schedule 5.

560 Treasury to Minister of Finance, “Tainui Settlement: Status of Ohinewai - Coalcorp Lands,” 26 May 1995 , TP-02-030-00-03, OTS archive.

${ }^{561}$ Tainui Māori Trust Board v. Attorney-General (1989); McCan, Whatiwhatihoe, 273-296.

562 Treasury to Minister of Finance, “Tainui Settlement: Status of Ohinewai - Coalcorp Lands,” 26 May 1995 , TP-02-030-00-03, OTS archive.
} 
Act effected with respect to their former lands. ${ }^{563}$ As was noted earlier, under Section 24(4) of the State-Owned Enterprises Act, Section 40 of the Public Works Act does not apply to the transfer of lands from the Crown to State-Owned Enterprises. The Crown argued that the Ohinewai lands that Coalcorp planned to purchase were being sold to Waikato-Tainui on the condition that Coalcorp could subsequently lease-back the lands from Waikato-Tainui to complete the term of mining privileges that it still held under the Coal Mines Act 1979. ${ }^{564}$ The land was still necessary for public purposes under the Public Works Act 1981.

In the middle of intense negotiations nearing a Deed of Settlement with WaikatoTainui in mid-May 1995, Cabinet agreed to the principle that where land was subject to a Section 27B memorial under the Treaty of Waitangi Act (State-Owned Enterprises) 1988 Section 40 offer-backs under the Public Works Act were waived. ${ }^{565}$ Waikato-Tainui did not take their claim through the Waitangi Tribunal, even though they had registered their claims with the Tribunal in 1987. They had chosen the path of direct negotiations and as a result lands they claimed were not subject to any recommendations or binding orders by the Tribunal. Nonetheless the effect on the Waikato-Tainui negotiations of the 27B memorial scheme established by the 1988 amendment to the State Owned Enterprises Act was still marked. The Ohinewai lands were set to be returned to Waikato-Tainui in the wider context of their Treaty settlement negotiations as Graham explained to National MP Rob Storey, who had taken up the cause of the farmers:

The whole basis of the settlement with Tainui was to try to return as much of the confiscated lands as was feasible. Tainui could have simply gone to the Waitangi Tribunal and sought a mandatory order for the return of the lands covered by the

\footnotetext{
563 Graham to Rob Storey, 25 May 1995, TP-02-030-00-03, OTS archive.

564 OTS Director to Graham, “Crown Land Administered by Coalcorp,” 13 June 1995, TP-02-030-00-03, OTS archive.

${ }^{565}$ CAB (95) M 17/5, TP-02-030-00-03, OTS archive: "The Crown agrees that Section 40 offer back requirements under the Public Works Act should not apply in the case of transfer of SOE land consistent with the principle established in Section 8A5 of the Treaty of Waitangi Act.”
} 
memorials. The Crown would not have been able to oppose such an application and the effect of such an order would have been to override the Section 40 provision. Rather than go through the application to the Tribunal, the consent of the Crown, and the return pursuant to the memorial without the Section 40 applying, it was agreed that the Tainui legislation would simply return those lands without the Section 40 offer-back as if a mandatory order had been made. ${ }^{566}$

Graham also made similar comments in the media. ${ }^{567}$ What Graham did not state was that the Tribunal had never made a binding order to return SOE lands, although it would once in its history later in $1998{ }^{568}$ Furthermore as Damian Stone has noted, "the original intent of the statutory memorials was to ensure that land transferred to state-owned enterprises would remain available for use in Treaty settlements," however, “the Crown’s preference is to use more readily available Crown land (such as land-banked land and Crown forest licensed land), rather than memorialised land.”569 This was the case in both Waikato-Tainui and Ngāi Tahu's negotiations.

Internally the Crown debated what path to take as OTS, CLO and Treasury officials tried to determine how to preserve the Ohinewai lands for the Waikato-Tainui settlement and for Coalcorp’s own proposed operations. ${ }^{570}$ The Ohinewai lands were a fairly significant part of the land area that was proposed to be returned to Waikato-Tainui, constituting $7.4 \%$ of the total area. The Attorney-General, Paul East, believed that fresh legislation was necessary to

\footnotetext{
${ }^{566}$ Graham to Storey, 25 May 1995, TP-02-030-00-03, OTS archive.

567 “Ohinewai farmers face disappointment,” Mana News, 5 July 1995; “Farmers Can’t Buy Back Power Station Land,”5 July 1995: TP-02-030-00-03, OTS archive.

${ }^{568}$ Waitangi Tribunal, The Turangi Township Remedies Report (Wellington: Waitangi Tribunal, 1998). The Crown and Ngāti Turangitukua reached an agreement before the Tribunal's binding recommendations came into effect.

${ }^{569}$ Damian Stone, 'Chapter 10. The Financial and Commercial Dimensions,' 143: Stone stated that more readily available Crown land was used "because most of this memorialised land is utilised in, and is often integral to, the commercial operations of an existing state-owned enterprise.” Stone could have also noted that private owners of memorialised land would cause difficulties in terms of public perception if land was purchased back and then transferred to Māori claimants.

${ }^{570}$ ToWPU official 4 to CLO, Treasury, Chapman Tripp and Paul Hendry, 12 June 1995; Treasury to ToWPU official 4, 13 June 1995: TP-02-030-00-03, OTS archive
} 
overrule the Public Works Act. ${ }^{571}$ Coalcorp had intended to purchase the land in June 1994, but had delayed as a result of the on-going Waikato-Tainui negotiations. In August 1995 Coalcorp exercised its option to purchase the Ohinewai lands but they were not used in the settlement as a result of Deane and Levin's legal proceedings. While Deane and Levin continued their proceedings in Court to have their former lands offered back to them, MP Rob Storey also continued his own efforts to lobby Graham on behalf of the two farmers. ${ }^{572}$ He proposed that the Crown provide compensation to the farmers for the loss of their offerback rights. In addition Storey also made some controversial comments that symbolised some of the backlash that existed to Treaty settlements. Storey brought to Graham's attention a concern he had with the proposed transfer of residential properties that were all in the same street or in one village:

I do not have any concerns about Māori as tenants any more than I would about Europeans as tenants, but I am concerned about a preponderance of rental accommodation at the lower end of the market which can present a number of social problems. I understand Tainui has a policy of not selling any land once they have acquired that land, and recognise that it is a matter for them to deal with, and I will raise it with them. ${ }^{573}$

His comments reflected the views of some of the Pākehā majority who feared the social effects of the return of land to Māori claimants.

Although Graham did not address the final portion of Storey’s letter in which he expressed concerns with a concentration of Waikato-Tainui tenants in a geographical area, he did address Storey’s proposal for compensation. Graham did not agree that compensation should be provided to those farmers that did not have their offer-back rights exercised. He believed that those farmers, just as others who had their lands taken under the Public Works

\footnotetext{
571 "Farmers upset over threat to land return,” Waikato Times, 19 July 1995 \& “Trouble with Tainui deal,” New Zealand Herald, 19 July 1995: RC June-September 1995 Vol 41, Box 19.

${ }^{572}$ Storey to Graham, 6 July 1995, TP-02-030-00-03, OTS archive.

${ }^{573}$ Storey to Graham, 26 July 1995, TP-02-030-00-03, OTS archive.
} 
Act, were paid full market compensation for their lands. Graham felt that it would have been inequitable to provide further compensation to one group of former landowners when it was not practical to do so for all landowners. ${ }^{574}$ His concerns would remain but he was overruled in Cabinet.

The third reading of the Waikato-Tainui settlement legislation at Parliament passed in November 1995 and neither Levin nor Deane’s former lands were used in the settlement, but previous land owners were provided with the possibility to obtain $\$ 20,000$ for the loss of purchasing rights. ${ }^{575}$ Section 42A of the Public Works Act (inserted by Section 38 of the Waikato-Tainui settlement legislation, the Waikato Raupatu Claims Settlement Act 1995) provided up to $\$ 20,000$ to former owners of Crown land who would have been offered a right to purchase their former lands had Section 8A(5) of the Treaty of Waitangi Act not extinguished that right. ${ }^{576}$ The Levin and Deane proceedings were not heard until the middle of 1996 and a decision was delivered by Judge Hammond in December 1996.

Judge Hammond found in favour of Deane and ordered that the approximately 78 hectares of land that was offered back to him for purchase in 1989 was to be offered to him by Coalcorp again. Hammond found that Coalcorp had effectively entered into a legally protected agreement to sell the land back to Deane in 1989. In the case of the much larger approximately 600 hectare section of land formerly belonging to the EG Levin Farm Settlement Trust, Judge Hammond found in favour of the Attorney-General. In Levin's case Coalcorp had not entered in an agreement to sell as they had with Deane. The Judge decided that the land was still to be used for a public work, despite the fact that the Coalcorp had temporarily changed its mind at one five month interval in 1989 when it had proposed to sell

\footnotetext{
${ }^{574}$ Graham to Storey, 9 August 1995, TP-02-030-00-03, OTS archive.

${ }^{575}$ Waikato-Tainui Raupatu Claims Settlement Act 1995, Attachment 2.

${ }^{576}$ Public Works Act 1981, Section 42A.
} 
the land to another party. While Coalcorp had breached its obligations under Section 40 of the Public Works Act by not offering the land back to Levin first in 1989, that did not entitle Levin to purchase back the land. It is unclear if Levin's lands were eventually transferred to Waikato-Tainui as part of their Treaty settlement but it is clear that Deane’s land was not. ${ }^{577}$

The grievances expressed by some of the former landowners were enveloped in the negotiations for the Waikato-Tainui settlement but they had their origins in the 1988 Sale and Purchase Agreement between the Crown and Coalcorp. It was under the terms of the 1988 Sale and Purchase Agreement that the rights of former owners were first removed. ${ }^{578}$ The matter had become further complicated by the injunction imposed by the High Court in Tainui Māori Trust Board v. Attorney General in 1989, but it was the transfer of assets that resulted from the State Owned Enterprises Act 1986 rather than the 1995 Waikato-Tainui settlement that began the process.

\footnotetext{
${ }^{577}$ August Daniel Deane v. Attorney-General \& Henry Michael Horton and Barrie McCormick Campbell as trustees of the EG Levin Farm Settlement Trust v. Attorney-General (1996): TP-02-030-00-03, OTS archive. ${ }^{578}$ OTS Director to Graham, 27 June 1995, AAKW W5105 781222 Tainui: 1995 Pt.4, Archives NZ.
} 


\section{Conclusion}

The return of land to Waikato-Tainui and Ngāi Tahu was an important part of each Treaty settlement. Waikato-Tainui's focus on the return of land as the central component of their settlement was emblematic of their desire to have the maximum amount of land transferred. This focus also reflected the specific context of Waikato-Tainui's negotiations, since their settlement was restricted to the return of land rather than other conservation issues. Waikato-Tainui sought mechanisms to retain the land and pushed for a form of customary title under which returned lands would be inalienable. Ngāi Tahu's settlement consisted of the return of different categories of land-commercial and cultural redress. Ngāi Tahu sought mechanisms to retain important sites of significance but not as Waikato-Tainui had desired. For Ngāi Tahu the return of areas in fee simple title was adequate to ensure that essential lands such as the Crown Titi Islands were retained. Nonetheless both Waikato-Tainui and Ngāi Tahu sought the return of lands without marginal strips. The different ways that Waikato-Tainui and Ngāi Tahu approached the return of land reflected the unique manner in which each iwi sought to re-assert their rangatiratanga. The Crown's limits on the form in which lands were returned was equally reflective of the Crown's absolute sovereignty.

Both Waikato-Tainui and Ngāi Tahu were concerned regarding the continuing alienation of Crown lands in their respective regions during the negotiations. The development of a protection mechanism to allow Ngāi Tahu and Waikato-Tainui the opportunity to reserve certain Crown lands for use in a future settlement, the land-bank, slowed the alienation of Crown land. The Crown established Ngāi Tahu's land-bank first in 1990 and Waikato-Tainui's land-bank in 1993.The land-bank system was not perfect and it often frustrated Ngāi Tahu and Waikato-Tainui, but it was an innovative method to protect at least some Crown lands from alienation. The inclusion of three high-country pastoral leases 
at Elfin Bay, Greenstone and Routeburn Stations in the Ngāi Tahu land-bank reflected an active desire by the Crown to facilitate Ngāi Tahu's settlement aspirations. Nonetheless as a result of internal Crown pressure from DoC and external lobbying from conservation and sports recreation organisations, a large majority of the land contained in these high-country pastoral leases was retired into the conservation estate. This was a direct challenge to Ngāi Tahu’s rangatiratanga.

The difficulties experienced by Waikato-Tainui and Ngāi Tahu to have Crown lands returned resulted from both Crown actions and those of third-parties such as conservationists. Restrictions on the return of certain Crown lands, such as DoC lands, emerged from opposition within the Crown but also from prominent conservation groups. The return of the Crown Titi Islands and other sites of significance to Ngāi Tahu were delayed for many years as a result of this opposition. Waikato-Tainui's desire for the return of DoC lands, or at the least a strong co-management role in DoC lands in the Waikato confiscation area, was similarly opposed by both DoC and third-party conservation interests. The return of land to Waikato-Tainui was also complicated by other third-party interests in addition to conservationists. Two former private owners of Crown land taken under the Public Works Act, believed that they should have been offered land before its possible use in WaikatoTainui's negotiations, and their actions successfully restricted the use of some Crown lands in the settlement. For Waikato-Tainui and Ngāi Tahu the return of land was governed by both their negotiations with the Crown but also the influences of outside interests. In this way both Waikato-Tainui's rangatiratanga and the Crown's kawanatanga were challenged by thirdparty interests. 


\section{Chapter 4 - The Politics of History and Treaty Settlements: The Formulation of Historical Accounts (preambles) and Apologies}

Treaty settlement negotiations are intended to address and resolve historical claims by Māori against the Crown. The negotiations are infused with a wide range of historical debates regarding the history of colonisation in New Zealand. Early in the Waikato-Tainui negotiations it became clear that the Crown would need to go beyond purely monetary redress and even the return of land — an apology was necessary and a historical account of the relations between the Crown and Waikato-Tainui. ${ }^{579}$ Former Treaty Negotiations Minister Doug Graham has commented that historical events needed to be put in "their proper place not forgotten but accepted.” ${ }^{580}$ State apologies have increased in prominence since the late twentieth century especially. Historians, political scientists, sociologists and lawyers have explored the development of apologies by the state in North America, Europe, Japan, Australia and New Zealand. ${ }^{581}$ While these works have explored the political and historical contexts to apologies by the state, there has not been any analysis of the specific process of producing the state apology and historical account, and the players involved. Some of these works have also largely focused on apologies at the state-level rather than the iwi level apologies that marked the Crown’s apologies to Waikato-Tainui and Ngāi Tahu, especially the scholarship of Melissa Nobles, Robert R. Weyeneth, Kenneth Minogue and Michael Cunningham. ${ }^{582}$ The work on apologies has been limited to the formulation and context of

\footnotetext{
${ }^{579}$ Hickey, “Crown Apologies,” 82.

${ }^{580}$ Graham, Trick of Treaty?, 74.

${ }^{581}$ Roy L. Brooks (ed.), When Sorry Isn't Enough: The Controversy Over Apologies and Reparations for Human Injustice (New York University: New York, 1999); Charles S. Maier, 'Overcoming the Past? Narrative and Negotiation, Remembering and Reparation: Issues at the Interface of History and the Law', in John Torpey (ed.), Politics and the Past: On Repairing Historical Injustices, Lanham, 2003, pp. 295-304; Nicholas Tavuchis, Mea Culpa: A Sociology of Apology and Reconciliation, Stanford, 1991.

${ }^{582}$ Robert R. Weyeneth, "The Power of Apology and the Process of Historical Reconciliation,” The Public Historian, v. 23, no. 3; Kenneth Minogue, 'Aborigines and Australian Apologetics,' Quadrant, September 1998, pp. 11-20; Michael Cunningham, "Prisoners of the Japanese and the Politics of Apology: A Battle Over History and Memory,” Journal of Contemporary History, v. 39, no. 4, 2004; Michael Cunningham, “Saying Sorry: The
} 
the apologies, rather than the historical accounts that are prominent in the New Zealand Treaty settlement process. The historical accounts and the apologies that are produced are meant to be as unbiased, unemotional and neutral as possible but the process behind them reveals a series of discussions occurring between the Crown and Waikato-Tainui and Ngāi Tahu. If Linda Smith is correct and the writing of "history is mostly about power," then these debates reflected the assertion of Waikato-Tainui and Ngāi Tahu's rangatiratanga, and the Crown’s defence of its own sovereignty. ${ }^{583}$ Waikato-Tainui and Ngāi Tahu understandings of their respective histories with the Crown often differed from their Crown counterparts, and it is within these interactions that some sense of shared historical understanding was created. As one OTS official commented during the latter stages of the Waikato-Tainui negotiations, historical accounts embodied the "need to reconcile the Crown's desire for brevity and clarity with Waikato-Tainui's desire to set the historical record straight."

The confiscation of land that lay at the center of Waikato-Tainui's historical claims was often discussed during the early phase of Waikato-Tainui's negotiations dating back to the first scoping discussion in 1989, and remained prominent throughout the negotiations with National in the early 1990s. Once it became clear that a settlement would occur, work began by both the Crown and Waikato-Tainui on crafting what was referred to as a "preamble" (to the settlement agreement) but which was essentially a historical account. The historical debates between Waikato-Tainui and the Crown addressed the different understandings of the origins of the war in the Waikato during the 1860s and the aftermath and effects of war through to the present day. These involved Waikato-Tainui chief negotiator Robert Mahuta and his legal advisors, Denese Henare and Shane Solomon, and

Politics of Apology,” The Political Quarterly, v. 70, 1999; Elazar Barkan, The Guilt of Nations; Melissa Nobles, The Politics of Official Apologies (New York: Cambridge University Press, 2008).

${ }^{583}$ Linda Tuhiwai Smith, Decolonizing Methodologies, 34.

${ }^{584}$ OTS official 4 to Graham, 10 July 1995, AAKW W5105 781222 Tainui: 1995 Pt.4, Archives NZ, 1. 
Waikato-Tainui's historical advisor, Ann Parsonson. Officials at the ToWPU/OTS (it was restructured into OTS on 1 January 1995 a week and a half after the signing of the Heads of Agreement), the CLO and Parliamentary Counsel were involved on the Crown side. Since the Waikato-Tainui preamble and apology was the first of its kind in the New Zealand Treaty settlement process, the negotiations were spread over three preambles that were produced for each phase of the negotiation: in the period before the signing of the Heads of Agreement from October to December 1994, before the signing of the Deed of Settlement in May 1995 and the first introduction of settlement legislation in July 1995. Each preamble was slightly different, but also shared some common sections and characteristics.

Ngāi Tahu’s history had been examined to a far greater extent than Waikato-Tainui's due to Ngāi Tahu’s Waitangi Tribunal hearings form 1987-1989. While Ngāi Tahu and the Crown each had concerns with the conclusions in the Ngāi Tahu Report, they agreed to use the Report as the baseline for the negotiation. The quantification of loss was the first site of historical debate in Ngāi Tahu's negotiations with National in the early 1990s but it only lasted for approximately a year. As the negotiations slowly began to break down in 1993 and 1994, the historical debates ended. It was not until the negotiations had recommenced and led to a Heads of Agreement in 1996 that historical debates resumed between the Crown and Ngāi Tahu. Much like the development of Waikato-Tainui’s preamble and apology, there were widely differing views on the history of Ngāi Tahu's colonisation but a final compromise was reached. Ngāi Tahu’s primary historical advisor was Te Maire Tau and he was aided by Ngāi Tahu legal advisor Nick Davidson. OTS and CLO officials were similarly involved, but none from the Parliamentary Counsel office.

Julie Bellingham has argued that the Crown has used the preamble (or historical accounts) and apologies to liberate itself from past wrongs and blame, rather than as an 
accurate historical account. Bellingham questioned the extent of Māori claimant input into the formulation of historical accounts, and noted the Crown's dominance of the process. ${ }^{585}$ The negotiations over Waikato-Tainui’s preamble, Ngāi Tahu’s historical account and apologies to both iwi reveal that many of Bellingham's observations were correct. Both iwi complained about the Crown's refusal to include historical details and the Crown's control of the overall process. Nonetheless, Bellingham overlooks the agency and role of Māori claimants, in this case Waikato-Tainui and Ngāi Tahu negotiators, in the formulation of the accounts and apologies. Both Waikato-Tainui and Ngāi Tahu had significant input into their apologies and historical accounts and obtained important concessions in the final versions. Richard Boast has commented that historical accounts are "inevitably lifeless, tedious to read and indeed to write." ${ }^{586}$ What this chapter will show is that although the accounts and apologies tend to have the most neutral tone and uncontroversial historical positions, the debates that occur between the Crown and claimants are far from lifeless. Indeed, these debates embody the clash between Māori rangatiratanga and the Crown’s kawanatanga at the centre Waikato-Tainui and Ngāi Tahu’s Treaty settlement negotiations.

\section{Part I: The development of Waikato-Tainui's preamble(s) and apology}

\section{The Preamble to the Heads of Agreement}

In early October 1994 Cabinet approved a general mandate for Graham to develop a concrete offer for Waikato-Tainui negotiators. This provided the context for extended historical debates between Crown and Waikato negotiators regarding the wording of the preamble and the apology. The Crown sent Waikato-Tainui negotiators a draft of their proposed preamble in early October 1994 that was split into recitals denoted by a letter. The

\footnotetext{
${ }^{585}$ Bellingham, “The Office of Treaty Settlements and Treaty History,” M.A Thesis Victoria University of Wellington, 2006, 63-131.

${ }^{586}$ Richard Boast, The Native Land Court 1862-1887: A Historical Study, Cases and Commentary (Wellington: Brookers Ltd., 2013), 13.
} 
Crown's account took note of the tensions in the 1860s and that the Crown had acted in violation of the Treaty of Waitangi. The account stated that the New Zealand Settlements Act 1863 was used to "wrongfully" confiscate 1.2 million acres areas of land in the Waikato. The preamble referred to the Waitangi Tribunal's 1985 Manukau Report which found that the Crown's invasion of the Waikato was contrary to Article II of the Treaty of Waitangi. The Crown sought to recognise that the physical and economic impact of the raupatu "both immediately and over time has been prejudicial to Waikato-Tainui and caused economic, social and cultural upheaval” and had contributed "to the development of New Zealand.” Waikato-Tainui’s negotiating principles of "i riro whenua atu, me hoki whenua mai” (as land was taken, so land should be returned) were explicitly recognised. ${ }^{587}$ In its essence this did not differ much from the Crown position as far back as 1990.

The specific wording of the preamble would become a focal point of the negotiating process, and especially the terms used to describe the severity of Crown actions and effects. Internally the Crown was still struggling with the extent and nature of the Crown's recognition of wrong-doing. The Solicitor-General had reviewed the Crown's preamble draft and wondered what was "meant by the contribution to the development of New Zealand" and "by the contribution [of confiscated land] to the development of New Zealand. What is there that is relevant to the settlement?” A CLO official also had some trouble with that admission. Waikato-Tainui also sought to include that the acknowledgment of the contribution of raupatu land to the development of New Zealand was “quantified at approximately $\$ 6$ billion.” ${ }^{588}$ Waikato-Tainui negotiators requested that an acknowledgment of the financial loss be included in the preamble because of the significant difference between the estimates of loss and the final quantum provided. Although the issue of quantification of loss was not

\footnotetext{
${ }^{587}$ CAB (94) M 37/7; “Draft Heads of Agreement,” 12 October 1994: both TC 30 Vol. 37, OTS archive. ${ }^{588}$ CLO official 4 to ToWPU official 4, 17 October 1994, TC 30 Vol. 37, OTS archive, 5.
} 
as important for Waikato-Tainui as it was for Ngāi Tahu, it remained an important fact to ensure that there was recognition of the multi-billion dollar nature of Waikato-Tainui's loss. For Waikato-Tainui it was important to note that land confiscation had enabled New Zealand to develop a valuable dairy economy that it remains in many ways to this day-even if that dairy development had occurred decades after the initial confiscation.

Waikato-Tainui’s first response to the Crown's proposed preamble included a number of important suggested changes. While the Crown's version recognised the Tribunal's 1985 Manukau report that indirectly condemned the confiscation there was also added: "It [the actions of the Crown] is also contrary to the Sovereign Status accorded Maaori under the Declaration of Independence.” Waikato-Tainui wanted the Crown to not only acknowledge the ongoing relationship between Waikato and the Crown in terms of the Treaty of Waitangi but also the 1835 "Declaration of Independence,” He Whakaputanga o Niu Tireni. ${ }^{589}$ The Declaration was signed largely by northern New Zealand rangatira (“chiefs”), but also by Tainui rangatira Te Wherowhero in 1839 nineteen years before he was crowned the first Māori King. ${ }^{590}$ This was the first time that the issue had come up during the negotiations, and was intended by Waikato-Tainui to set the historical scene for the signing of the Treaty of Waitangi in the following year. The Declaration contained stronger references to sovereignty than the Treaty and as a result perhaps it was unrealistic for the Crown to accept its inclusion, but seeking to include it in the preamble would have been understandable from WaikatoTainui's point of view. ${ }^{591}$

At recital E the Crown stated: “The raupatu lands are estimated to total some 1.2 million acres (although some compensation in the form of land and cash was assigned to

\footnotetext{
${ }^{589}$ Tainui Māori Trust Board version of Preamble, 26 October 1994, TC 30 Vol. 38, OTS archive.

${ }^{590}$ Orange, Illustrated History of the Treaty of Waitangi, 13-16.

${ }^{591}$ Interestingly this issue persists throughout negotiations and Tribunal hearings, especially in light of the arguments made by Nga Puhi in the Paparahi o te Raki hearings since 2010.
} 
Māori in the Waikato through the compensation courts and other means).” Waikato-Tainui's version had more details and some more extended discussion of the merit of the WaikatoTainui claim in relation to other claims, and the process under which some lands were returned following confiscation:

The raupatu lands total some 1,202,273 million acres. Compensation in the form of cash and lands was assigned to Maaori in the Waikato through the compensation courts and to those Waikato Maaori who fought on the side of the Crown. These lands were not returned under the tribal estate but became part of the individual tenure title system of the Crown. ${ }^{592}$

At draft recital F the Crown held that "the physical and economic effect of the raupatu both immediately and over time has caused economic, social, and cultural upheaval to WaikatoTainui.” To Waikato-Tainui the word “upheaval” was inadequate: they argued that "decimation" was more suitable, and wanted to add that the "effect of the War caused physical loss in terms of lives terminated by the invading colonial forces of the Crown.” Waikato-Tainui wanted to refer to the compromise that had been reached by both sides as being made "especially on the part of Waikato-Tainui."593 The differences between Crown and Waikato-Tainui negotiators on these points were not really a matter of differing historical interpretations but of the inclusion of certain historical details. The inclusion of historical details in the end would play a key part in achieving reconciliation between the Crown and Waikato-Tainui claimants, as the support of Waikato-Tainui beneficiaries could often hinge on what kind of recognition had been achieved by Waikato-Tainui negotiators.

Graham himself was intimately involved in these negotiations much as Mahuta was. After advice from his officials, Graham responded to Waikato-Tainui’s desired changes to the Crown's first draft with his own suggestions. Graham refused to mention the Declaration of Independence, but acknowledged that "cash and lands were assigned to Maaori in the

\footnotetext{
592 Tainui Māori Trust Board draft preamble, 26 October 1994, TC30 Vol 36, OTS archive.

593 Tainui Māori Trust Board draft preamble, 26 October 1994, TC 30 Vol. 38, OTS archive, 1-2, 5.
} 
Waikato through the compensation courts but, it appears, to those Waikato Maaori who fought on the side of the Crown. These lands were not returned under the tribal estate but became part of the individual tenure title system of the Crown.” It was also conceded that the effect of war was beyond upheaval to extend, as Waikato-Tainui had wanted, to “decimation.” Graham also noted in the Crown's obligations that the grievances of WaikatoTainui were "justified and that recognition of that fact is overdue." Graham allowed for the inclusion that the raupatu land was estimated by "Waikato-Tainui to have a value today of approximately \$6 billion.”594

CLO provided their own views on the Waikato-Tainui version of the preamble. One official did not approve of using the term “decimation” rather than upheaval, presumably because of its literal meaning. In section 3 , in terms of good faith obligations, the CLO official wondered why the compromise of both sides had to be referred as "especially on the part of Waikato-Tainui.” During these debates over historical issues, very recent issues could often also be tightly interconnected such as the recent compromise that Waikato-Tainui thought they were making in accepting the Crown's proposed financial compensation and the return of only certain lands, for example the exclusion of the conservation estate. ${ }^{595}$ The draft preamble returned to Waikato-Tainui at the end of October 1994 only kept those changes approved by Graham. ${ }^{596}$

Crown officials then turned to a historian who was not affiliated with the government to seek additional help with the task of composing a history that was not only acceptable to both Waikato-Tainui and Crown negotiators, but also historically accurate. Academic

\footnotetext{
${ }^{594}$ Graham notes on Heads of Agreement, 27 October 1994, TC 30 Vol. 38, OTS archive

${ }^{595}$ CLO official 4 to ToWPU official 4, 31 October 1994, TC 30 Vol. 38, OTS archive; Graham notes on Heads of Agreement, 27 October 1994, TC 30 Vol. 38, OTS archive, 1-2, 5-6.

596 ToWPU official 4 to Robert Mahuta, 31 October 1994, RC1: RC December - August 1994, Box 32, W-T archive.
} 
historian James Belich was used as a consultant to review and comment on a draft of the preamble. The Crown had privately expressed to Belich a hesitancy to use the word "invasion” to describe the military incursion across the Mangatawhiri and into the Waikato. To the Crown Law Office the British acquired sovereignty in 1840 when the Treaty of Waitangi was signed, and thus the Crown could not invade itself. Admitting to the invasion of the Waikato would make the Crown liable to question its own sovereignty. Belich was blunt in his advice: "I understand that there is some reluctance to use the term 'invasion'. While re-registering my firm opinion that this term is historically accurate, I acknowledge that 'the Crown engaged in a war in Waikato' is legitimate. There is no shadow of doubt that military operations in the Waikato were initiated by the Crown.” The ongoing debate between Waikato-Tainui negotiators and the Crown, as well as within the Crown between Graham and the CLO, over whether to use the term upheaval or decimation to describe the result of confiscation on Waikato-Tainui was quickly resolved by Belich. “'Decimation' literally means reduction by one-tenth; in common usage it seems to tend towards reduction by ninetenths. Neither is accurate; 'caused heavy economic, social, and cultural damage to WaikatoTainui' may meet the case.” Belich concluded his historical advice with a recognition of the momentous nature of the negotiations, "I would like to record my congratulations to your unit and minister for what will, in my view as a specialist in the field and as a New Zealand general historian, be a major step forward in NZ ethnic relations.”597

When a third Crown draft of the preamble was sent to Waikato-Tainui negotiators at the end of November 1994, there were only cosmetic changes to the issues accepted for the second Crown draft at the end of October 1994. There remained recognition of the effect of the individual tenure title system on the dismantling of the tribal estate. In addition, Belich's

\footnotetext{
${ }^{597}$ James Belich to ToWPU official 4, 1 November 1994, TC30 Vol. 39, OTS archive, 1-2.
} 
recommendation for "heavy economic, social and cultural damage” rather than "upheaval” or “decimation” was also accepted. ${ }^{598}$

While there was general agreement on the preamble there were a number of historical details which Mahuta proposed to add to the preamble. Mahuta also sought to challenge the legal framework under which confiscation was first effected. During the late 1980s WaikatoTainui negotiators had consistently questioned the legality of the confiscations. Crown officials maintained that the confiscation of land was legal, albeit unjust. ${ }^{599}$ Waikato-Tainui requested that the words "unlawfully" be added to the sentence "large areas of land.....were [“unlawfully” rather than unjustly] confiscated by the Crown.” The Crown continued to hold to the view that the confiscation had been legal. ${ }^{600}$ Mahuta also wanted the passages from the Manukau Report that condemned the invasion of the Waikato rather than solely a reference to the Report, and Article II of the Treaty of Waitangi in English and Te Reo Māori. ${ }^{601}$ The Crown accepted the inclusion of Article II, although it rejected the inclusion of the passage from the Manukau Report because it seemed to point to the illegal nature of the confiscation. By the final version of the Heads of Agreement preamble, a statement from the Manukau Report was included: "It can simply be said that from the contemporary record of Sir John Gorst in 1864, from the Report of the Royal Commission sixty years after that, and from historical research almost a century removed from the event, all sources agree that the Tainui people of the Waikato never rebelled but were attacked by British troops in direct violation of Article II of the Treaty of Waitangi.” The use of a Waitangi Tribunal report in the WaikatoTainui preamble signified the historical authority that the Tribunal still held, despite Waikato-

\footnotetext{
598 "Draft Heads of Agreement," 29 November 1994, TC30 Vol. 40, OTS archive.

${ }^{599}$ Frame to Henare, 1 March 1989, TC30 Vol. 3, OTS archive; Frame to Jeffries, 30 May 1989, TC30 Vol. 3 , OTS archive; Meeting minutes of Tainui Māori Trust Board and the Crown scoping session, 8 June 1989, TC30 Vol. 3, OTS archive.

${ }^{600}$ Michael Litchfield, “The Confiscation of Māori Land,” VUW Law Review Vol. 15 No. 4 1985, 337-362.

${ }^{601}$ Waitangi Tribunal, Report of the Waitangi Tribunal on the Manukau Claim (Wai-8), (Wellington: Government Printer, 1985).
} 
Tainui's choice to skip the Tribunal process and proceed directly to negotiations. While the legality of the confiscation was not questioned in the excerpt from the Manukau Report, the statement that “Waikato never rebelled” pleased Waikato-Tainui negotiators.

Mahuta thought that the preamble was far too brief and wanted to provide a more detailed historical account by referring to the purpose of the Kīngitanga, the reason for invasion by the Crown and specific sites of atrocities such as at Rangiaowhia and Orakau:

The pivotal role in which the King movement played in the attempt to preserve the tribal lands. The attacks that occurred by the colonial forces such as at Rangiaowhia. The troops attacked the unfortified village where a number of families were living. The people of the village hastily sought refuge in the whare near the Church. After a short volley of fire from both sides the whare were set alight. Those who came out to escape the flames were shot. Those who remained were burnt to death. The heavy casualty suffered by the people including women and children as people evacuated en masse the village of Orakau as it was surrounded by 1100 soldiers. ${ }^{602}$

Mahuta also sought to exclude some historical details. ${ }^{603}$ Strangely, although Waikato-Tainui advisors had previously requested that the effect of the individual tenure system and the process for the return of confiscated lands be specifically mentioned, by 9 December 1994 they asked for its removal from the preamble. They originally desired the addition of the following statement: “Compensation in the form of cash and lands was assigned to Maaori in the Waikato through the compensation courts and to those Waikato Maaori who fought on the side of the Crown. These lands were not returned under the tribal estate but became part of the individual tenure title system of the Crown.” ${ }^{604}$ The Crown had only added "or those who remained neutral” to "those Waikato Maaori who fought on the side of the Crown." 605 Waikato-Tainui wanted the statement deleted in its entirety so that this specific section of the

\footnotetext{
${ }^{602}$ Mahuta to Peter Rowe, 7 December 1994, RC1, Correspondence Vol 37, December 1994, Box 15, W-T archives.

${ }^{603}$ Mahuta to Rowe, 7 December 1994, RC1, Correspondence Vol 37, December 1994, Box 15, W-T archive; Rowe to ToWPU official 4, 9 December 1994, TC 30 Vol. 41, OTS archive, 1; Belich, The New Zealand Wars and the Victorian Interpretation of Racial Conflict, 173.

${ }^{604}$ Tainui Māori Trust Board draft preamble, 26 October 1994, TC30 Vol 36, OTS archive.

${ }^{605}$ Crown draft Heads of Agreement, 29 November 1994, TC30 Vol. 40, OTS archive.
} 
preamble would only refer to the confiscation of land, not the process that followed. ${ }^{606}$ When another draft was produced on 13 December 1994 the section noted above was still in the preamble, but italicised and in parentheses with a hand-written checkmark directly beside it. The copy of the draft belonged to the lead ToWPU official. This official had met with Graham to discuss the preamble that day and Graham may have indicated that the section should remain. ${ }^{607}$ It is unclear why Waikato-Tainui would have wanted to remove those specific historical details. By the 15 December 1994 version of the Heads of Agreement, the reference was still included and it would remain the same format for the final version of the preamble in the Heads of Agreement signed by Graham and Mahuta on 21 December $1994 .^{608}$

Crown Law had objections to many of Mahuta's proposed changes. Mahuta had asked that the wording should include that the confiscation was unlawful while CLO reiterated the injustice of the act but that the confiscation was legal. CLO noted: "The effects of such a concession [that the confiscation was unlawful] is that all that occurred subsequently is illegal and even though this is a without prejudice document I do not think the Crown should make a concession.” ${ }^{609}$ The CLO argument in relation to the legality of confiscation was connected to the Crown's refusal to use the term "invasion" to describe the war. Both concessions undermined the Crown's absolute sovereignty.

CLO also had concerns with many of the historical statements provided by Mahuta. The statement that “Tainui never rebelled” raised “a number of historical issues” for Crown

\footnotetext{
${ }^{606}$ Mahuta to Rowe, 7 December 1994, RC1, Correspondence Vol 37, December 1994, Box 15, W-T archive; Rowe to ToWPU official 4, 9 December 1994, TC 30 Vol. 41, OTS archive, 1. ${ }^{607}$ Crown draft Heads of Agreement, 13 December 1994, TC30 Vol. 41, OTS archive.

${ }^{608}$ Crown draft Heads of Agreement, 15 December 1994, TC30 Vol. 41, OTS archive.

${ }^{609}$ CLO official 4 to ToWPU official 4, 9 December 1994, TC 30 Vol. 41, OTS archive.
} 
Law although specific reason for their concern was not provided. The CLO official found that many of the historical statements requested by Mahuta were contradictory:

[The fact that Waikato were] labelled as rebels to justify confiscation - seems unnecessary given the Crown's admission that the confiscations were unjust (people can draw their own conclusions from that admission); did not wish to sell their lands when? eg Waikato Chiefs sold land in the 1840s; role of King movement - relevance?; cause of confiscation - again, it is difficult to see the relevance especially in light of the Crown's admission. 610

The CLO official also struggled to understand why the atrocities at Rangiaowhia and Orakau were singled out. A legal consultant for the Crown largely agreed with CLO's comments on the changes to the preamble regarding the illegality of the settlement and that the Crown would probably object to that historical interpretation. The legal consultant stated that:

Perhaps it would be opportune to provide Tainui with the draft apology prepared by Frame [the former ToWPU Director] to see whether that would go some way towards meeting their requirements. I would be particularly concerned at any acknowledgment by the Crown that the land is conservatively valued at six billion dollars. I also recall Frame's comment that it would be dangerous for the Crown not to acknowledge the casualties on the Crown side as well. ${ }^{611}$

Some of Crown Law's comments were correct. Waikato-Tainui rangatira had sold land but the role of the King movement was to stop the land sales, and this was strongly connected to the reason for invasion and subsequent confiscation. ${ }^{612}$ Mahuta was the (adopted) son of King Koroki and his sister was Te Arikinui, the Waikato-Tainui negotiating team and the King Movement were strongly intertwined. ${ }^{613}$ As for Rangiaowhia and Orakau the reason for its inclusion by Waikato-Tainui negotiators was as a tool of remembrance but the Crown sought to keep the historical details to a minimum. Waikato-Tainui negotiators wanted to ensure that

\footnotetext{
${ }^{610}$ CLO official 4 to ToWPU official 4, 9 December 1994, TC 30 Vol. 41, OTS archive.

${ }^{611}$ CLO official 4 to ToWPU official 4, 9 December 1994, TC 30 Vol. 41, OTS archive, 2; Mark O’Regan to Thomas, 9 December 1994, TC 30 Vol. 41, OTS archive, 1.

${ }^{612}$ McCan, Whatiwhatihoe, 32; Keenan, Wars Without End, 206-214; Belich, The New Zealand Wars, 78-79; Michael King, Te Puea: A life (Auckland: Penguin, 1977), 24.

${ }^{613}$ Carmen Kirkwood, Te Arikinui and the Millenium of Waikato (Ngaruawahia: Turongo House, 2001).
} 
the murder of the elderly, women and children at Rangiaowhia and wounded soldiers and women at Orakau were emphasised and specifically recognised by the Crown. ${ }^{614}$

During a mid-December 1994 meeting the Crown stated that the preamble "should take a broad brush approach to historical matters in the document and avoid detailed debate on historical points and interpretations.” Waikato-Tainui negotiators were fairly resigned to having to accept the finality of the settlement and tried to advance their own historical agenda on that point. "Denese [Henare] wanted to know if the settlement was full and final then why can't we put what we like into it in respect to the historical facts?” Brent Wheeler noted that the detail of the historical facts should not become a "slinging" match. "It is not an issue of blame - it is an issue of factual statement and correction.”615 This reflected some of the observations made by historian Julie Bellingham regarding the necessity of factually correct historical accounts and apologies. ${ }^{616}$ Many of Waikato-Tainui’s requested changes to the preamble were not included in the final Heads of Agreement that was signed by Mahuta and Graham on 21 December $1994 .^{617}$ The description of the confiscation as “unlawful” was not included, but there were many points of recognition of injustices perpetrated against Waikato-Tainui including that the "War caused loss of life among Waikato-Tainui and the physical and economic effect of the raupatu both immediately and over time has caused heavy economic, social and cultural damage to Waikato-Tainui.” The extract from the Manukau report which stated that "the Tainui people of the Waikato never rebelled" was also included, something Denese Henare was particularly concerned about. ${ }^{618}$ A final aspect that Waikato negotiators did manage to have changed was the reference to the value of the land

\footnotetext{
${ }^{614}$ Belich, The New Zealand Wars, 160-165, 173; Vincent O’Malley, “Te Rohe Pōtae War \& Raupatu: A Report Commissioned by the Crown Forest Rental Trust, 2010,” 107-129, 144-178.

${ }^{615}$ ToWPU official 4, 13 December 1994 Meeting, TC 30 Vol. 41, OTS archive; Solomon,13 December 1994 Meeting, RC1, Correspondence Vol 37, December 1994, Box 15. 2-3.

${ }^{616}$ Bellingham, "The Office of Treaty Settlements and Treaty History,” 72.

617 "Waikato-Tainui and Crown Heads of Agreement," 21 December 1994, TC30 Vol. 42, OTS archive.

${ }^{618}$ Henare to Mahuta, 19 December 1994, RC1, Correspondence Vol 37, December 1994, Box 15, W-T archives.
} 
confiscated. It had been estimated at approximately $\$ 6$ billion in 1989 but in the intervening years it had doubled to increase to $\$ 12$ billion as a result of inflation and increased land prices. The preamble in the Heads of Agreement would include the change to \$12 billion, a minor consolation, but a small victory nonetheless. ${ }^{619}$ While the first version of the preamble in the final Heads of Agreement was completed, the apology remained to be crafted.

\section{The Royal Apology}

The development of the Crown's apology to Waikato-Tainui began in early November 1994, during the drafting of the preamble. The Crown contracted Alex Frame, the first ToWPU Director and leading official of the scoping negotiations that took place under the Labour government in the late 1980s, to develop the first draft of the apology. He had gone into private practice, but was now contracted to help formulate the apology to Waikato. Frame advised Graham that the apology and preamble needed to contain an admission by the Crown of having breached the spirit of the Treaty of Waitangi by crossing the Mangatawhiri in 1863. This was inevitably a political assessment "painted with a broad brush, taking into account modern conceptions of the Treaty of Waitangi” and disregarding features which would be relevant in a narrow legal analysis. Frame stated that "ministers have concluded, no doubt rightly, that the intensifying cycle of grievance/confrontation/grievance can only be

broken by a bold admission by the Crown and the tendering of substantial compensation.” 620 His first draft had noted that Waikato-Tainui kuia (female elders) had expressed feeling like “orphans” during the scoping discussions of 1989 and wanted to include that detail in the apology. Frame later wrote that his use of the term "orphans” had caused the Crown some concern. The use of the term "orphans” was outside of the usual neutral terminology

\footnotetext{
619 Te Maru to ToWPU official 4, 17 December 1994, TC 30 Vol. 42, OTS archive.

${ }^{620}$ Frame, "First Draft Apology," 9 November 1994, TC 30 Vol. 39, OTS archive; Frame to Graham, 22 November 1994, TC 30 Vol. 40, OTS archive, 2.
} 
advocated by the Crown. ${ }^{621}$ Nonetheless Crown officials and Ministers recognised the importance of using such emotive terminology and it was included in the final version of the apology. ${ }^{622}$ Part of the final apology stated:

The Crown acknowledges that the subsequent confiscations of land and resources under the New Zealand Settlements Act 1863 of the New Zealand Parliament were wrongful, have caused Waikato to the present time to suffer feelings in relation to their lost lands akin to those of orphans, and have had a crippling impact on the welfare, economy and development of Waikato. ${ }^{623}$

The use of the term "orphans" and the general tone of the apology fit into the explanatory framework extolled by Elazar Barkan, wherein the apology demonstrates a new "guilt of nations.”624

The Crown sought to appease Waikato-Tainui's request to include historical details by stating that the details would appear in the apology during a mid-December 1994 meeting. Waikato-Tainui replied that if the important historical details would appear in the apology, then Waikato-Tainui preferred that Queen Elizabeth II delivered the apology personally at Turangawaewae Marae in Ngāruawāhia. This was the first instance that the delivery of the apology by Queen Elizabeth II was mentioned during the negotiations. Crown officials expressed their scepticism to the prospect of Queen Elizabeth II delivering the apology in person, but stated to their counterparts that they would investigate the possibility. ${ }^{625}$

In May 1995 when the apology was being finalised and prepared for the Deed of Settlement signing, Waikato-Tainui legal advisor Denese Henare remained concerned that it did not recognise that Waikato-Tainui had never rebelled. At consultation hui during the first few months of 1995, individuals had stated that the issue of rebellion was important to them so the pressure to include the statement that Waikato-Tainui had never rebelled came from all

\footnotetext{
${ }^{621}$ Bellingham, “The Office of Treaty Settlements and Treaty History,” 86.

${ }^{622}$ Frame, "Raupatu Settlement - Legal Finality and Political Reality,” 258.

${ }^{623}$ Waikato-Tainui Deed of Settlement, 22 May 1995, 6.

${ }^{624}$ Barkan, The Guilt of Nations.

${ }^{625}$ ToWPU official 4, 13 December 1994 Meeting, TC 30 Vol. 41, OTS archive; Solomon,13 December 1994 Meeting, RC1, Correspondence Vol 37, December 1994, Box 15. 2-3.
} 
levels of Waikato-Tainui society. ${ }^{626}$ The Crown countered that the extract from the Manukau Report in the preamble explicitly stated that "the Tainui people of the Waikato never rebelled.” The final version of the apology contained an acknowledgment that the Crown's "representatives and advisers acted unjustly and in breach of the Treaty of Waitangi...in unfairly labelling Waikato as rebels” which may have appeased Henare. ${ }^{627}$

\section{Waikato-Tainui legal advisor Shane Solomon continued to stress to Crown} negotiators that the person that delivered the apology remained important. "The mere fact that Q[ueen]E[lizabeith]II apologises in person to Te Ata[irangikaahu] is vindication of our innocence and affirmation of the Crown's guilt and wrong doing.” The Crown had begun to inquire about the possibility of an apology from the Queen, especially in light of the myriad different grievances for which she might be responsible around the world due to the destructive effects of British colonisation. In letters to the editor the public also weighed inthey were largely opposed to an apology directly from the Queen. ${ }^{628}$ Those opposed to the apology directly from the Queen could have no idea of its importance to the acceptance of the settlement by Waikato-Tainui.

On 3 May 1995 Graham asked that Mahuta approve the wording of the apology. Prime Minister Jim Bolger was travelling to the United Kingdom in early May 1995 and would bring up the issue with the Queen and her advisors. Graham had wanted the word "imperial” removed from the first paragraph of the apology in which it stated that "imperial troops” had crossed the Mangatawhiri in 1863. Mahuta opposed and decidedly pointed out to the Minister that Waikato-Tainui had not deleted the word "imperial” from their draft of the

\footnotetext{
${ }^{626}$ Solomon to Te Maru, 3 May 1995, May 1995, (SS) Box 38, OTS archive.

${ }^{627}$ Waikato-Tainui Deed of Settlement, 22 May 1995, 6-7.

${ }^{628}$ Solomon to Te Maru, 3 May 1995, RC1, Correspondence May 1995, (SS) Box 38, W-T archive, 2; MFaT official 1 to the Ministry of Foreign Affairs and Trade, 14 February 1995, AAKW W5105 781222 Tainui: 1995 Pt.1, Archives NZ; Sue Freeman, “Tainui on a limb,” 8 March 1995, Waikato Times; Vernon White, "Royal Apology,” 9 March 1995, Waikato Times.
} 
apology. Clearly Graham was concerned about how the Queen and her advisors would perceive that part of the apology. Mahuta countered that "there should not be any difficulty with the Palace since Her Majesty should be advised it is historical fact that in 1863 British troops invaded the Waikato.”629 There was still opposition, prior to Bolger's meeting with the Queen, from the Crown to the inclusion of the term imperial to describe the troops.

Eventually the Crown came to believe that the alternative of "British" troops was probably even more objectionable because imperial troops could well refer to German or Japanese imperial troops. ${ }^{630}$ The word "imperial” remained a concern for the Crown and ultimately Waikato-Tainui had to accede to the use of the neutral "forces" to describe the Crown's troops that crossed Mangatawhiri. ${ }^{631}$

Before the apology was finalised for Bolger to take to the United Kingdom with him, the OTS Chief Historian also had a change he desired to the apology. In the second clause of the apology the Crown expressed "its profound regret and apologise[d] unreservedly for the loss of lives because of the hostilities arising from the land war...” The Chief Historian believed that the war was about more than just land but a clash of sovereigns and a violation of Waikato-Tainui's rangatiratanga. He advocated the use of the term "invasion” in place of "land war," despite the Crown's previous aversion to the use of the term in the preamble to the Heads of Agreement. James Belich had argued in a similar vein in The New Zealand Wars during the 1980s, and in his advice to the Crown regarding the preamble in November 1994. ${ }^{632}$ The final version of the apology would use the term "invasion” in place of land war.

\footnotetext{
${ }^{629}$ Graham to Mahuta, 3 May 1995 \& Mahuta to Graham, 4 May 1995, AAKW W5105 781223 Tainui: 1995 Pt.2, Archives NZ, 1.

${ }^{630}$ Solomon, “Diary Note: Meeting of Advisers,” 5 May 1995, 2; Niwa Nuri to Mahuta, 5 May 1995, RC1, Correspondence May 1995 Vol 40, Box 18, W-T archives.

${ }^{631}$ Waikato-Tainui Deed of Settlement, 22 May 1995, 6.

${ }^{632}$ Belich, The New Zealand Wars, 78-79; ToWPU official 4 to Gerard Brown, 6 May 1995, RC1, Correspondence May 1995 Vol 40, Box 18, W-T archives. Danny Keenan has more recently argued that the invasion of the Waikato was primarily a result of disputes over land: Danny Keenan, Wars Without End.
} 
The Queen and her advisors approved the apology and agreed to deliver the apology personally when the Queen visited New Zealand in October 1995. Waikato-Tainui negotiators had originally wanted the Queen to travel to Turangawaewae Marae to deliver the apology. ${ }^{633}$ The Queen was unable to change her arrangements and did not travel to Turangawaewae. Nonetheless she delivered the apology to Queen Te Atairangikaahu at Parliament in October $1995 .^{634}$

\section{The Preamble to the Deed of Settlement}

The significant historical issues that had been negotiated for the preamble prior to the signing of the Heads of Agreement from October to December 1994 were under negotiation again to the dismay of Waikato-Tainui negotiators in March 1995.Waikato-Tainui beneficiaries reported to Waikato-Tainui negotiators that they were very concerned that the historical details should be correct and not watered down. Shane Solomon had:

concerns about the changes made in the recitals as these are matters that have been focused on by the old people in our consultations - such as the acknowledgments, the reference to not being rebels in the Manukau report, the principle of recognition of the 'crime' not a 'wrong' etc. These are matters of substance that should not now be renegotiated in the DoS [Deed of Settlement]. There appears to be a significant watering down and a shift from the intention and purpose. I thought we (Waikato and the Crown) were to work co-operatively and not adversarily post HoA [Heads of Agreement]! ${ }^{635}$

Historical debates were revived again in May 1995 as the schedule became extremely tight to have a Deed of Settlement completed for the celebration of Te Arikinui's coronation which occurred annually on 22 May. Ann Parsonson began working intensively with Shane Solomon and Denese Henare to further develop a preamble for the final Deed of Settlement

\footnotetext{
633 Solomon, "Draft apology,” 6 May 1995, RC1, Correspondence May 1995, (SS) Box 37, W-T archives; Gerard Brown to ToWPU official 4, 6 May 1995, RC1, Correspondence May 1995 Vol 40, Box 18, W-T archives.

${ }^{634}$ Orange, Illustrated History of the Treaty of Waitangi, 222; McCan, Whatiwhatihoe, 295, 315.

${ }^{635}$ Solomon, "Deed of Settlement," March or April 1995, RC1, Correspondence Mar - Apr 1995, (SS) Box 35, W-T archive, 7.
} 
and the legislation. Parsonson's first draft addressed the issues in far too much detail for the Crown and made a number of points that the Crown refused to include in the preamble, such as the fact that Te Wherowhero signed the Declaration of Independence but not the Treaty of Waitangi. Parsonson canvassed the co-operation that had existed between the Waikato communities and Pākehā until 1856. Specifically Parsonson pointed to Governor Grey’s request to Te Wherowhero to protect the nascent settlement of Auckland when it was threatened by groups in the Tai Tokerau area in the 1840s, to counter-balance the old rationalisations that Waikato had been invaded because it threatened Auckland in the late 1850s and early 1860s. Parsonson also addressed the atrocities committed by imperial troops at Rangiaowahia and Orakau, a point that the Crown still refused to include in the preamble. ${ }^{636}$ Shane Solomon thought Parsonson’s preamble draft captured what had "happened" but acknowledged that the "Crown will probably rebuke most of what she has written." 637

In mid-May 1995 Waikato legal advisor Denese Henare complained that the Crown draft of the historical preamble appeared to take no account of Dr. Parsonson's draft. The Crown's draft did not even take extracts from the preamble to the Heads of Agreement that was produced in late 1994. The extract from the Treaty of Waitangi for example was only provided in English and therefore contained no reference to rangatiratanga. What was important to Henare was the nature and scope of the settlement and the basis of Te Wherowhero title, especially the pledges of land to the Kinngitanga. The OTS historian stated that the draft preamble was the result of a compromise between Parsonson's draft and that of

\footnotetext{
${ }^{636}$ Belich, The New Zealand Wars, 160-165, 173; Vincent O’Malley, “Te Rohe Pōtae War \& Raupatu: A Report Commissioned by the Crown Forest Rental Trust,” 2010, 107-129, 144-178.

${ }^{637}$ Parsonson to Myrtle Te Maru, 1 May 1995, RC1, Correspondence May 1995, (SS) Box 37, W-T archive; Parsonson to Solomon, 2 May 1995, RC1, Correspondence Apr - May 1995, (SS) Box 36; Solomon to Te Maru, 3 May 1995, RC1, Correspondence May 1995, (SS) Box 38, W-T archive, 3.
} 
Crown officials. ${ }^{638}$ Henare wanted the section from the Manukau Report which stated that Waikato had not rebelled that was in the preamble to the Heads of Agreement, but the Crown initially refused. In internal meetings Waikato negotiators referred repeatedly to the importance of stating that Waikato had never rebelled. The Crown was concerned that this could be used against them later in Court and recommended alternative wording such as that they were "unjustly labelled as rebels". A Waikato advisor commented in a memorandum to Mahuta and other advisors: "The 1863 Act allowed the people of Waikato to be so labelled. They recognise this was unfair and unjust but the legal fact is that the Act has provided that this happened and it did. The Crown's view was that to insert that Waikato never rebelled would mean the Act was wrong and therefore the confiscations were wrong and this is what the Crown were trying to avoid being made explicit or inferred." ${ }^{639}$ The passage from the Manukau Report was eventually added to the preamble to the Deed of Settlement, as it had been included in the Heads of Agreement. In the end Henare's desire to have the pledges of land to the Kiingiitanga was not in the preamble to the Deed of Settlement, but it would appear in some form in the preamble to the settlement legislation. ${ }^{640}$ While the preamble to the Deed of Settlement did not entirely meet their expectations, Solomon and Parsonson both believed that the preamble had come a long way since the original Crown draft that mentioned next to none of Waikato's historical concerns. ${ }^{641}$

The preamble for the Heads of Agreement and the Deed of Settlement were very similar. Both preambles stated that the "Crown had engaged in a war against Maaori in the Waikato, causing suffering to the people there,” and that after the war large areas of land

\footnotetext{
${ }^{638}$ The OTS historian stated that "We don't expect that either side will need to make any negotiations at this late stage." To which Henare wrote on the fax: "Too bad."

${ }^{639}$ Solomon, "Diary Note: Meeting of Advisers,” 5 May 1995, 2; Niwa Nuri to Mahuta, 5 May 1995, RC1, Correspondence May 1995 Vol 40, Box 18, W-T archives.

${ }^{640}$ Henare to Solomon, 10 May 1995; OTS official 5 to Gerard Brown, 12 May 1995; both: RC1, Correspondence May 1995, (SS) Box 37, W-T archives;

${ }^{641}$ Parsonson to Henare, 12 May 1995, RC1, Correspondence May 1995, (SS) Box 38, W-T archives; Solomon to Mahuta, 25 May 1995, RC1, Correspondence May 1995 Vol 40, Box 18, W-T archives.
} 
were "unjustly” confiscated. Both versions also contained the reference to the Manukau Report which stated that "the Tainui people of Waikato never rebelled," that the war had caused a series of negative impacts, and explicitly recognised Waikato-Tainui’s negotiations. But they also differed in a few ways. The preamble to the Heads of Agreement only contained Article II of the Treaty of Waitangi in Te Reo Māori and English, but the Deed of Settlement had the entire Treaty, including its own preamble. Unlike the Heads of Agreement, the Deed of Settlement's preamble made an extended discussion (for a document of such overall brevity) of the Sim Commission, especially the limits of its terms of reference. Waikato-Tainui negotiators had also sought a reference to the injustice done to those Waikato Māori both north and south of the Mangatawhiri, and it was included. The reference to the process of lands returned to individuals following the confiscation was completely removed from the Deed of Settlement. The documents were nearly identical, with slightly more information in one section, the Sim Commission, and complete deletion of another section, the process of the return of confiscated lands in the $19^{\text {th }}$ century. The Heads of Agreement and Deed of Settlement preambles would then form the basis for the final preamble produced for the settlement legislation.

\section{The Preamble to the Waikato Raupatu Claims Settlement Act 1995}

Following the signing of the Deed of Settlement there was a slight lull in the negotiations regarding the historical account. Nonetheless the wording of another historical preamble to the legislation remained the subject of negotiation until the introduction of the Waikato Raupatu Claims Settlement Act at the end of July 1995. While the Heads of Agreement and Deed of Settlement preambles had no headings, the preamble to the settlement legislation was much longer than either of the first preambles and contained a number of headings: Kingiitanga, Confiscations of Waikato Land, Royal [Sim] Commission, 
Waitangi Tribunal, Court of Appeal, Negotiations with the Crown, and Settlement of Claims. Waikato-Tainui requested the addition of the words "invasion" and "hostilities" to the heading that was titled “Confiscations of Waikato Land.” After having fought against the inclusion of the word invasion early in the negotiations over the historical account, the Crown now agreed to its inclusion in a heading within the preamble in addition to its inclusion in the apology. Henare and Parsonson's previous requests for further information regarding the purpose of the King Movement were also provided in this final version of the preamble. While information was added regarding the Kinngitanga, the limits of the Sim Commission’s terms of reference that were noted in the Deed of Settlement preamble were deleted. Waikato sought some greater detail regarding the Sim Commission's conclusions that the confiscations had been more than just excessive and that compensation was necessary but the Crown hesitated to include details regarding the Sim Commission. The change to the reference to the Sim Commission would continue to frustrate Waikato-Tainui negotiators and advisors. Crown Law continued to lobby for changes as well. Both the Heads of Agreement and Deed of Settlement preamble had referred to the Crown "unjustly" confiscating large areas of land, but Crown Law sought to change the reference to the confiscation of "an excessive quantity of land." 642 In the end "unjustly” was accepted, but the explanation of the limits of the terms of reference of the Sim Commission remained excluded.

After extended negotiations over the preamble that would accompany the settlement legislation, agreement was finally reached between Waikato-Tainui and Crown negotiators. The next task was for the Parliamentary Counsel to consult the document and prepare it for introduction to Parliament. The compromise preamble had resulted from lengthy negotiations and the changes recommended by Counsel did not sit well with Waikato-Tainui negotiators.

\footnotetext{
${ }^{642}$ Bill Patterson to Solomon, 14 July 1995, RC1, Correspondence June-September 1995 Vol 41, Box 19, W-T archives, $2,7$.
} 
In the draft provided to Parliamentary Counsel, Recital F had the Crown "wrongfully” confiscating approximately 1.2 million acres but Counsel wanted to have it changed again from "wrongfully” to “an excessive quantity of land.” In a memorandum to Mahuta, Solomon wrote that "the new draft infers that the Crown did not act wrongfully and that the only injustice of the confiscations was the amount of lands that were taken, inferring there was a basis for raupatu in the first place. This is a complete aberration of the settlement.” Additionally the drafter focused excessively on the Sim Commission's conclusions without noting the limits of the Commission. Crown officials tried to assure Waikato-Tainui negotiators that the drafter was only following a set of Parliamentary guidelines to follow in terms of drafting the legislation. Solomon countered that one had to "look at the unique nature of the circumstances surrounding this legislation.” It was "not every day that the Crown settle[s] with Maaori on a grievance...the impressions and statements made by the Crown (including the Minister) are not reflected in the Bill. In fact people received comfort from the Minister on issues such as acknowledgment that the Treaty was breached, there was a wrong, [that] the Crown wanted to atone without qualification. We ourselves negotiated on this basis and articulated in the consultation round to the people that this was case." Waikato legal advisor Bill Patterson concurred with Solomon. "The reaction on the Waikato side is that these changes are not inadvertent nor merely stylistic but reflect a stubborn reaction on the Crown side against the 'rewriting of history' even though the historians on both sides have been in substantial agreement.” The complaints from the Waikato-Tainui negotiating team were so strong that Graham attended the Cabinet Legislation Committee and ensured the description of confiscations as unjust was reinserted into the preamble. Nonetheless Solomon believed that the allusion to the necessity of some kind of confiscation still remained. ${ }^{643}$

\footnotetext{
${ }^{643}$ Solomon to Mahuta, 18 July 1995 \& Patterson to the Waikato Negotiating Team, 19 July 1995, RC1, Correspondence June-September 1995 Vol 41, Box 19, W-T archives, 1 \& 2.
} 
Parsonson's support for the use of the term "wrongfully" to describe confiscation remained throughout. The Crown wanted to use the term "individuals who fought for the Kīngitanga” to describe those Waikato who had fought against the Crown, but Parsonson claimed that it was inappropriate because it did not reflect the communal nature of sacrifice. Parsonson also made an extended comment regarding the view of the Sim Commission propounded by the drafter:

My main hope has always been that the ghost of the Sim Commission would be laid in the Preamble - in fact I had thought initially it could have been done much more directly by explaining that the Commission was limited in accordance with prevailing views at the time, both in its terms of reference and in its findings. To have an inadequate and poorly contextualised reference to [the] Sim [Commission] is worse than no mention at all - and I agree with Shane [Solomon] that if the ghost is in fact being allowed to walk again, we should simply back away.

One senses the disappointment that old historical arguments, long before settled with Crown negotiators re-emerged again and again. "I had thought the Crown would welcome the chance to explain why Sim had resulted in a settlement (in 1946) that could not be lasting - and hence why the Crown is making the present settlement. I thought this would give the Crown a chance to respond to possible criticism. Above all, it is important to Waikato that the Crown admit that although Sim represented some progress in acknowledgement of wrongs done at the time, it did not go nearly far enough.” Solomon was extremely tired having to negotiate with officials over the preamble and recommended that Waikato-Tainui present a lengthy submission to the Select Committee regarding the preamble. ${ }^{644}$

There were a number of submissions made to the Māori Affairs Select Committee regarding the Waikato settlement. This analysis will only concentrate on the submissions made in relation to the preamble and to the apology because of this chapter's focus on historical debates. Seven submissions were received concerning Recital C of the preamble. It

\footnotetext{
${ }^{644}$ Parsonson to Henare, 19 July 1995 and Solomon to Patterson \& Mahuta, 26 July 1995, RC1, Correspondence June to September 1995, (SS) Box 39, W-T archives, 4-6.
} 
stated that "[t]hose chiefs who formally pledged their land to Pootatau Te Wherowhero gave up ultimate authority over the land to him, along with ultimate responsibility for the wellbeing of the people, and through this bound their communities to the Kīngitanga, resisting further alienation of land.” The seven submissions argued that the rangatira of individual hapū had not given up ultimate authority over their land to Te Wherowhero as was recorded in the Recital. They were concerned that Recital C distorted the historical facts and perpetuated "the myth of surrender by independent hapū to the Kīngitanga." Neither the OTS Historian nor Waikato's historian, Ann Parsonson, agreed that a change was warranted. Six submissions were received in relation to Recital H which asserted that "the Kingitanga has continued to sustain the people since the Raupatu.” The dissenters contended that it was not the Kingitanga which sustained the people but the people that sustained the Kingitanga. The OTS Historian advised that the whole question was a false dichotomy since the Kingitanga could not have existed without the people but that the Kinngitanga had clearly provided a moral leadership role for many Māori. Dr John Miller, as he had written in newspaper articles previously, submitted that Waikato had rebelled and further that Waikato had threatened Auckland. The Crown though differed on these two points and while acknowledging that there was "scope for historical interpretation on all the matters in the Preamble" the Recital was “factually correct.",645

Waikato-Tainui also made submissions on its reservations with the portrayal of the Sim Commission in the preamble. Waikato-Tainui believed that the inadequacy of the Commission's term was not obvious enough in the preamble. The Crown countered in Select Committee that the Sim Commissions' limitations were clearly present throughout the

\footnotetext{
${ }^{645}$ John Miller submission to the Māori Affairs Select Committee, August 1995, AAKW W5105 781222 Tainui: 1995 Pt.5, Archives NZ.
} 
preamble, even if it was not specifically stated. ${ }^{646}$ Since the Crown refused to revert the preamble to its pre-Parliamentary drafting form regarding the limitations of the Sim

Commission, Waikato-Tainui included an extended section on the changes it desired to the preamble in its submission to the Select Committee. Waikato made submissions on the limitations of the Sim Commission and provided a more detailed explanation as to why the Sim Commission's focus was so limited.

For instance, the Commission was instructed not to accept any argument that the confiscation legislation (the New Zealand Settlements Act and its amendments) was beyond the competence of the colonial parliament - an instruction which seems to reflect sensitivity to the debate on this point, inside and outside Parliament, in 1863-4. The imperial government had taken legal advice when considering the legislation in 1864, after a handful of leading colonists raised doubts as to parliament's power to legislate for the compulsory taking of Maaori land. These men argued against the passing of the Settlements Act on the grounds that it violated the protection of Maaori lands afforded by the Treaty of Waitangi and that Parliament should not deal with the lands of people who were unrepresented there. ${ }^{647}$

Parsonson noted there was considerable debate between politicians and colonists on the government's ability to confiscate land in such a wide-ranging manner. Māori Affairs Minister John Luxton made a reference in his speech to Parliament during the Bill's first reading regarding these debates. He discussed the opposition of James Fitzgerald, William Swainson and Dr. Daniel Pollen to the original confiscation legislation when it was introduced in $1863 .{ }^{648}$ As Michael Allen has shown, Fitzgerald would turn out to be a strong supporter of more wide-scale confiscation by the time he was in office in 1865. It is not clear whether Luxton's officials were aware of Fitzgerald's support for the confiscation in 1865 when he was in office. ${ }^{649}$ In any case, Luxton's speech supported the submissions made by

\footnotetext{
${ }^{646}$ Unknown author, ? August 1995, AAKW W5105 781222 Tainui: 1995 Pt.5, Archives NZ.

647 “Waikato-Tainui Raupatu Claims Settlement Bill: Submissions on Behalf of Waikato-Tainui,” 25 August 1995, RC1, Correspondence June-September 1995 Vol 41, Box 19.

${ }^{648}$ New Zealand Parliamentary Debates, Vol. 549, 8326-8328.

${ }^{649}$ Michael Allen, "Illusory Power? Metropole, Colony and Land Confiscation in New Zealand, 1863-1865,” in R Boast and R Hill (eds.) Raupatu: The Confiscation of Māori Land (Wellington: VUW Press, 2009).
} 
Waikato-Tainui regarding their concerns with the legislation's preamble. Graham was also in agreement with Waikato as his speech to Parliament at the first reading of the legislation echoed the very points Waikato negotiators had recently been arguing with the Parliamentary Counsel. ${ }^{650}$ The diverse viewpoints that were present in the many different drafts of the preambles to the Heads of Agremeent, the Deed of Settlement, and the legislation represented the series of different Waikato-Tainui and Crown interpretations of the history of war and confiscation in the Waikato. The preamble and the apology were in no way definitive histories of the war, confiscation and its aftermath, but they represented one attempt at some reconciliation. These historical debates indicate that the reconciliation process between Waikato-Tainui, Ngāi Tahu and the Crown were based on notions of compromise, but especially a recognition by the iwi that every detail desired would not be possible.

\section{W.H. Oliver, the preamble to the Waikato Raupatu Claims Settlement Act 1995 and the return of confiscated lands in the nineteenth century}

The preamble in the Deed of Settlement signed on 22 May 1995, which was much shorter than either the Heads of Agreement preamble or settlement legislation preamble, made no reference to the return of lands following confiscation. The preamble in the final legislation, much like the Heads of Agreement preamble, made a direct reference to the context and process of the return of some confiscated lands but with altered wording:

[T] he Crown subsequently paid small amounts of monetary compensation and returned, by Crown grants, but not under customary title and generally not to those who had fought for the Kingiitanga, approximately one-quarter of the land confiscated. ${ }^{651}$

Previously Waikato-Tainui had requested that the people to whom some of the original confiscated lands had been returned be referred to as "those who had fought on the side of the

\footnotetext{
${ }^{650}$ New Zealand Parliamentary Debates, Vol. 549, 8318-8320.

${ }^{651}$ Waikato Raupatu Claims Settlement Act 1995, Recital F.
} 
Crown.” By the settlement legislation the Crown and Waikato-Tainui had compromised and now referred to lands being returned "generally not to those who had fought for the Kiingiitanga” rather than just "those who had fought on the side of the Crown.” The history of the return of lands would become a point of academic controversy.

The preamble produced in the legislation was put under considerable scrutiny by historian W.H. Oliver not long after the legislation passed its third reading. The criticisms Oliver made of the Crown's proposals for Treaty settlements earlier in 1995 had been in line with many of the criticisms made by wider Māoridom—such as the inadequate fiscal envelope and the lack of consultation with Māori—but his critique of the preamble was different. ${ }^{652}$ His criticism of the preamble to the legislation focused on three aspects.

Firstly, he questioned whether the people actually pledged their authority to the King or conferred upon the Kinngitanga merely a veto to prevent further sales? This was a very complex and complicated question that he only left two sentences to address. Was the right to veto lands sales not prominent evidence of authority—surely this was a form of mana whenua and a prominent aspect of authority in the Māori world? His second point was that the preamble stated that the Crown "initiated hostilities." Oliver felt this implied that the Crown burst upon a "peaceful scene” when the situation in Waikato was allegedly “disturbed.” While he attempted to qualify his criticism with the recognition that the Crown had failed to explore other possibilities and had over-reacted by crossing the Mangatawhiri, he seemed to miss the larger point about why the Waikato district was “disturbed.” He states that "Kīngitanga Māori were not without a share in the responsibility for that." Historian Julie Bellingham supported Oliver's statement that "Māori were not without their responsibility for [the war]." She commented that it was unjust that the Crown "has been put on trial and only

\footnotetext{
${ }^{652}$ W.H. Oliver, “Pandora’s envelope: it’s all about power,” New Zealand Books, March 1995, 18-20.
} 
its actions have been the subject of inquiry."653 Both Oliver and Bellingham neglect to note that the “disturbed” state of the Waikato may have occurred because of the Crown's forced disturbance in the Taranaki, and its aggression towards the King Movement. ${ }^{654}$

Oliver's final criticism, the only critique upon which he expanded at length, focused on the statement that land had been "returned...generally not [Oliver's italics] to those who had fought for the Kingiitanga” which he believed was a “curious, even an evasive, phrase.” ${ }^{655}$ He believed that without thorough research on the issue there should not have been any statement made at all. Bellingham again supported Oliver's views and highlighted the Crown's failure to reference the Appendix to the Journal of the House of Representatives official reports that suggested a considerable amount of land had been returned to individuals designated as “returned rebels.”656 Originally Waikato-Tainui argued that the returned lands had been transferred to "those Waikato Māori who fought on the side of the Crown." The reality was that some land had been returned to Māori individuals designated by the New Zealand Parliament as "returned rebels.” But there are two limits to that evidence. The first is the unilateral Crown control of the designation of "returned rebel.” It is unclear how Parliament arrived at those designations. Secondly, and more importantly, these lands were likely to be the least productive and profitable lands in the region. ${ }^{657}$

More important than the criticisms of the sources which Oliver offers to support his position, was that the use of the phrase "generally not" was a compromise between the parties. Waikato-Tainui originally wanted to refer to those who were returned lands following confiscation as having fought entirely for the British. The Crown felt that some lands were

\footnotetext{
653 Bellingham, “The Office of Treaty Settlements and Treaty History,” 71.

${ }^{654}$ Belich, The New Zealand Wars, 73-98; Keenan, Wars Without End, 71-204.

${ }^{655}$ W.H. Oliver, “Getting facts on your side,” New Zealand Books, December 1995, 15.

${ }^{656}$ Bellingham, “The Office of Treaty Settlements and Treaty History,” 73-74.

${ }^{657}$ Craig Innes and James Mitchell, "Alienation of Māori granted lands within Te Rohe Pōtae Parish extension, 1863-2011," Report Commissioned by the Waitangi Tribunal (Wai 898, \#A30), 2013; Appendix to the Journals of the House of Representatives, "Further Papers Relative to Confiscated Lands," 1873 Session I, C-04B.
} 
returned to those who had opposed the Crown, as Oliver had in fact later advocated, and the use of "generally not" was the middle point between the parties. OTS historians had wanted to reply to Oliver in NZ Books, but were not allowed by their superiors who wanted the issue to pass without further comment. ${ }^{658}$ The OTS historian that worked on the preamble and apology did comment later to Julie Bellingham that he considered Oliver’s criticism unfair, and that Oliver "showed no real appreciation of the type of document" that the settlement had produced. ${ }^{659}$ This was another example of the many compromises that had to be reached to produce the preamble. ${ }^{660}$ The intriguing question is why publish an article for such a small and specific column, what motivated Oliver to do this? In many ways it prefigures his "retrospective utopias" thesis: in his critique of the preamble to the Waikato-Tainui legislation he is attempting to uncover a form of history that he sees as corrupt because it serves a uniquely political end that distorts what actually happened. ${ }^{661}$

Historians working for both claimants and the Crown were inevitably politicised by their craft—-they had a certain goal in mind with the evidence they were presenting and the arguments they were making. But this tends to ignore the fact that even academic historians who are not subject to specific briefs which state that only breaches of the Treaty need to be explored will have their own socio-economic and political imperatives. As EH Carr has noted, history "is a continuous process of interaction between the historian and the facts, an unending dialogue between the present and the past.”" ${ }^{662}$ Richard Evans similarly commented

\footnotetext{
${ }^{658}$ Interview with ToWPU official 3, 11 October 2011.

${ }^{659}$ Bellingham, “The Office of Treaty Settlements and Treaty History,” 73.

${ }^{660}$ Richard Hill, “Historical 'Facts' and the Waikato Raupatu Claims Settlement Act 1995,” Stout Centre Treaty Research Series, http://www.victoria.ac.nz/stout-centre/research-units/towru/publications/Historical-Facts-andthe-Waikato-Raupatu.pdf, accessed 2 March 2015.

${ }^{661}$ W.H. Oliver, "The future behind us: the Waitangi Tribunal's Retrospective Utopia," in Andrew Sharp and Paul McHugh (eds.) Histories, Power and Loss (Wellington: Bridget Williams Books, 2001); W.H. Oliver, Looking for the Phoenix: A Memoir (Wellington: Bridget Williams Books, 2002).

${ }^{662}$ EH Carr and Richard Evans, What is History? (London: Palgrave, 2001), 30.
} 
that "historians are always led by their present-day concerns.”663 Miranda Johnson has explored the unease which Oliver (and Giselle Byrnes) have had with "the possibility of a deep connection between the past and the present," concluding that their "concern that the past is being judged by the standards of the present reveals an anxiety that the past will not be distinguished from the present.” Acknowledging the existence of the deep connection between the past and the present is essential to understanding Treaty settlement processes and seems to be missing from the critiques of Oliver and others such as Giselle Byrnes. ${ }^{664}$ History as an academic endeavour has always been heavily influenced by political ideologies and figures and this has continued in many ways during the involvement of historians in New Zealand's Treaty settlement process.

\section{Part II: Debates over Ngāi Tahu's preamble and apology}

The historical debates regarding Ngāi Tahu’s historical account and apology began soon after their interim settlement was signed in June 1996. The OTS historian assigned to the Ngāi Tahu claim met with Ngāi Tahu’s historian, Te Maire Tau, in the middle of that month. OTS' terms of reference included a strong reliance on the Tribunal report for findings of breaches of Treaty principles. The OTS historian reported to other Crown officials that Tau was largely content with the terms of reference. Tau also wanted a statement added which acknowledged that the "two parties would be approaching the statements from different cultural contexts and these contexts should be reflected in the statements.” This kind of thinking reflected Tau's later work on the same issue. In "Matauranga Māori as an Epistemology” Tau argued that traditional Māori knowledge was a separate form of knowing

\footnotetext{
663 Richard J. Evans, In Defence of History (London: Palgrave, 1997), 230.

${ }^{664}$ Miranda Johnson, “Making History Public: Indigenous Claims to Settler States,” Public Culture, 20:1, 97117, 117. Johnson also critiqued Giselle Byrnes who extended Oliver's arguments in The Waitangi Tribunal and New Zealand History (Auckland: Oxford University Press, 2004).
} 
that had to be preserved from the methods of Western epistemology. ${ }^{665}$ In that vein Tau wanted the preamble to have a specific structure that would begin with a karakia followed by a poroporoaki, mihi, a kaupapa and to finish with a specially commissioned waiata for the occasion. The apology was to be delivered orally as well as in written form. While many Ngāi Tahu members wanted the ceremony on a marae, Tau believed the occasion was of national significance and also wanted it in a public place so possibly there would be two ceremonies. ${ }^{666}$

Tau also advocated for royal involvement in the ceremony since Waikato-Tainui had received royal assent and Waikato-Tainui had a history of antagonism to the Crown. Tau pointed out that Ngāi Tahu had always been very loyalist, raising funds for the campaigns in Waikato and Taranaki and sending many soldiers to both world wars. ${ }^{667}$ There was no opposition from the Crown for this recognition. The final version of the apology contained a section specifically addressing Ngāi Tahu's loyalty and military sacrifice for the nation:

The Crown recognises that Ngāi Tahu has been consistently loyal to the Crown, and that the tribe has honoured its obligations and responsibilities under the Treaty of Waitangi and duties as citizens of the nation, especially, but not exclusively, in their active service in all major conflicts up to the present time to which New Zealand has sent troops. The Crown pays tribute to Ngāi Tahu's loyalty and to the contribution made by the tribe to the nation. ${ }^{668}$

As had occurred during the intense negotiating period in 1992 and 1993 regarding the quantification of loss, the issue of tenths remained as a point of difference between Crown and Ngāi Tahu representatives. Ngāi Tahu historians maintained that the principle of tenths mentioned in the 1991 Ngāi Tahu Tribunal Report applied to all of the purchases of land by the Crown and thus it was within that grievance that the large part of the value of Ngāi

\footnotetext{
${ }^{665}$ Te Maire Tau, "Matauranga Māori as an Epistemology," in A. Sharp and P. McHugh (eds.), Histories, Power and Loss: Uses of the Past - A New Zealand Commentary (Wellington: Bridget Williams Books, 2001), 61-73. ${ }_{666}$ OTS official 5 to CLO contractor, 19 June 1996, Chapman Tripp Materials, OTS archive.

${ }^{667}$ OTS official 5 to CLO official 5 \& CLO official 6, 30 July 1996, NE-12-027-00-04 Pt. 2, OTS archive; OTS official 5 to CLO contractor, 19 June 1996, Chapman Tripp Materials, OTS archive, 1.

${ }^{668}$ Ngāi Tahu Deed of Settlement, 22 November 1997, 3.
} 
Tahu's loss resides. The Crown Law historian questioned the validity of the Ngāi Tahu claim to tenths in the Otakou purchase, and opposed the notion of tenths for all of the purchases. The Tribunal found that there was no evidence to support the contention by Ngāi Tahu that the Crown had promised to retain for Ngāi Tahu a tenth of the land that had been sold at Otakou. Nonetheless the Tribunal did state that had the Crown reserved a tenth of the land purchased at Otakou, and across all of the purchases of land from Ngāi Tahu, it would have been "greatly to the advantage of Ngāi Tahu." ${ }^{669}$ The Crown Law historian noted that even those groups such as the Port Nicholson Trust that had tenths awarded in the mid-nineteenth century were not provided with a tenth of the lands in private ownership, but rather were used for educational or whatever civilising purposes the Government of the day desired. He claimed that not only would the land have been used in whatever way the Government of the day had decided, but that "it may have been that, with the increasing genetic migration of Ngāi Tahu in to the European population, the balance might have swung more towards public rather than purely native purposes." ${ }^{670}$ A recognition that the notion of "tenths" had not applied for each and every land purchase, especially considering the size of the Ngāi Tahu rohe compared to other groups around the country, is uncontroversial. Nonetheless the rationalisation of a critique of tenths by making excuses for the manner in which colonial governments formulated land trusts for Māori is questionable. Making guesses at the potential use of such lands because of alleged "genetic migrations” is similarly unhelpful to the overall project of historical reconciliation, even though this memorandum was not put directly to Ngāi Tahu.

Interestingly the detail upon which the Crown Law historian wanted to expand regarding how the issue of tenths might have played in each individual area was the opposite

\footnotetext{
${ }^{669}$ Waitangi Tribunal, The Ngāi Tahu Report, (Wellington: Waitangi Tribunal, 1991), 828-829.

${ }^{670}$ CLO official 6, "Extract from my memo on the 15 July version of the recitals," 24 July 1996, NE-12-027-0004 Pt. 2, OTS archive, 1.
} 
of what the Crown generally sought regarding the negotiation over the preamble for the Waikato settlement. The Crown's focus in Waikato-Tainui's preamble was on a very general interpretation of the history with as little detail as possible. In this case it was Ngāi Tahu that wanted to provide a more general view of the issue of tenths while Crown historians wanted to restrict any mention of tenths strictly to the Otakou purchase. Crown Law sought to explain that the Crown's obligations to Ngāi Tahu could have been achieved by the use of tenths but that they could also have been achieved in another manner. Ngāi Tahu historians rejected this approach. Their view on the issue of tenths was supported by other historians such as Ranginui Walker and Ngāi Tahu’s Pākehā historians, especially Ann Parsonson and Harry Evison. ${ }^{671}$ The CLO historian was firm in his view of the alleged "reality of the history" and pointed to the Tribunal's findings on the issue. In his advice to his superiors he painted a rather stark picture of the way in which history was being used to the benefit of Ngāi Tahu. In correspondence with Tau regarding tenths the OTS historian also relied on the Tribunal's findings. ${ }^{672}$ The issue of tenths would remain the most contentious historical issue, and in the end it was included solely for the description of the purchase of the Otakou block with the qualification that Crown may also have achieved its obligations in another manner:

The Tribunal considered that the Crown's obligation [to make further provision for Ngāi Tahu in the purchase of the Otakou block] might have been satisfied by the creation of 'Tenths', or by other adequate provision. ${ }^{673}$

The Tribunal report was also referred to in relation to disagreements regarding the inclusion of other historical details. The Crown had purchased lands from Ngāi Tahu around Banks Peninsula in 1849 through Land Purchasing Commissioner Walter Mantell. The Tribunal found that Mantell had been unnecessarily high-handed in negotiations with Ngāi

\footnotetext{
${ }^{671}$ Walker, Ka Whawhai Tonu Matou, 105-110; Harry Evison, The Long Dispute: Māori Land Rights and European Colonisation in Southern New Zealand, 139-157; Ann Parsonson, "Evidence of Dr Ann R Parsonson on the Otakou tenths," Report for Ngāi Tahu claimants in the Ngāi Tahu Waitangi Tribunal inquiry, C1, 1987. ${ }^{672}$ OTS official 5 to Te Maire Tau \& Nick Davidson, 24 July 1996, NE-12-027-00-04 Pt. 2, OTS archive. ${ }^{673}$ Ngāi Tahu Deed of Settlement, 22 November 1997, 14.
} 
Tahu for the Port Levy Block section of Banks Peninsula, and had unfairly denied them reserves at Okains Bay and Pigeon Bay: "It is plain that Ngāi Tahu did not wish to sell land at Okains Bay and at Pigeon Bay. But they were overborne by Mantell, in clear breach of article 2 which required the consent of Ngāi Tahu to the sale of their land." ${ }^{674}$ Ngāi Tahu had claimed that they had also requested reserves in another area within the Port Levy block, the Kaituna Valley, but the Tribunal did not comment on the validity of the Kaituna Valley claims. Tau wished to include that Mantell had denied reserves requested by Ngāi Tahu at Okains Bay, Pigeon Bay and Kaituna Valley in the historical account. ${ }^{675}$

The OTS historian expressed his concern with the Tribunal's lack of commentary on Kaituna Valley and was hesitant to include the Kaituna Valley in the historical account. Nonetheless the OTS historian recognised that the Tribunal may have been mistaken in omitting the request to reserve Kaituna Valley from the purchase from its finding. He stated to Tau that OTS was “quite prepared to accept that the Tribunal merely overlooked Kaituna Valley, provided that there is good contemporary evidence that, as with the other two sites, Ngāi Tahu requested this reserve and were unjustifiably turned down. You may be able to supply us with such a reference. In the meantime, we will try to pin the matter down.”676 Ngāi Tahu maintained that Kaituna Valley had merely been overlooked by the Tribunal and that Ngāi Tahu requests for its exclusion had occurred. The only reference that Ngāi Tahu provided was the work of historian Harry Evison, who was affiliated with Ngāi Tahu. His primary source analysis of the Port Levy Purchase revealed that the Kaituna Valley was a culturally and economically significant fertile area of land. During the negotiations regarding the purchase of Port Levy, some members of Ngāi Tahu specifically asked for its

\footnotetext{
${ }^{674}$ Waitangi Tribunal, The Ngāi Tahu Report, 561.

675 Te Maire Tau to OTS official 5, 29 July 1996, NE-12-027-00-04 Pt. 2, OTS archive.

${ }^{676}$ Te Maire Tau to OTS official 5 to Te Maire Tau \& Nick Davidson, 24 July 1996, NE-12-027-00-04 Pt. 2, OTS archive.
} 
exclusion. ${ }^{677}$ The OTS historian recommended to his superiors that the historical account include the reference to Kaituna Valley. He argued for its inclusion as a result of Evison’s research and the historical context of the Port Levy purchase. ${ }^{678}$ Due to the historical evidence and the wider context of Crown intransigence in the purchase of the specific block in which Kaituna Valley was meant to be reserved, the reference to Kaituna Valley was included: “Significant to the Tribunal's findings on the Port Levy purchase was the Crown's refusal to make reserves, as requested by Ngāi Tahu, at Okains Bay, Kaituna Valley and Pigeon Bay.”679

The Crown's concerns with the inclusion of certain details by Tau in the historical account also applied to Tau's draft of the apology. Tau wanted the following phrase incorporated into the apology: "The Crown recognises that it has failed in every material aspect to meet the obligations to Ngāi Tahu, its Treaty partner which arose from the Deeds of Purchase whereby the Crown acquired Ngāi Tahu land in the South Island, and to act towards Ngāi Tahu with the utmost good faith in a manner consistent with the honor of the Crown. Indeed the Crown admits that its failure to act in good faith reduced several generations of Ngāi Tahu to a state of landlessness, poverty and failed to protect their rangatiratanga.” ${ }^{680}$ Tau's draft of the apology was too uncompromising for the CLO. While the Tribunal Report provided a thorough reference for both groups of historians there were still issues that were left open to debate. Tau stressed that the Crown had caused Ngāi Tahu complete landlessness while Crown Law emphasised that while the reserves were small, they still had some land reserved. A related point was Tau's contention in his draft of the apology that the "Crown

\footnotetext{
${ }^{677}$ Evison, The Long Dispute, 218-219.

${ }^{678}$ OTS official 5, "Ngāi Tahu History,” 29 August 1996; CLO official 5 to OTS official 5, 29 August 1996; OTS official 5 to CLO official 5, 5 September 1996; OTS official 5 to Te Maire Tau, 5 September 1996, all: NE-12-027-00-04 Pt. 2, OTS archive.

${ }^{679}$ Ngāi Tahu Deed of Settlement, 22 November 1997, 15.

${ }^{680}$ Te Maire Tau to OTS official 5, 29 July 1996, NE-12-027-00-04 Pt. 2, OTS archive. (my italics)
} 
had failed in every material aspect to meet the obligations of Ngāi Tahu.” Both the OTS and CLO historian agreed that "every material aspect” was inaccurate. Although there was resounding failure on the Crown's part it was not quite in “every material aspect.” The OTS historian also alluded to the difficulties that the term "every material aspect" could present for Parliamentary Counsel when the settlement legislation was being drafted. This comment could have been a reference to extended negotiations that occurred with Parliamentary Counsel during Waikato-Tainui's negotiations. ${ }^{681}$ Much as the term "decimation” had been the subject of attention for Waikato-Tainui and Crown historians to describe the effect of Crown policies on Waikato-Tainui people, Ngāi Tahu wanted the Apology to describe the Crown as having had acted "unconscionably" in relation to the purchase of lands and apportioning of reserves for Ngāi Tahu. The OTS and CLO historians both agreed that the term "unconscionably” was too strong as it had not been specifically noted in the Tribunal Report. $^{682}$

The OTS historian replied to Tau with CLO's concerns regarding the use of the term "landlessness" and the notion that the Crown had failed to meet its obligations to Ngāi Tahu in "every material aspect." ${ }^{683}$ Tau’s subsequent draft retained the terminology in both sections of the apology. ${ }^{684}$ Although the reference to landlessness and a failure by the Crown to meet its obligations in "every material aspect” would not remain, Tau was able to retain the use of the term “unconscionably” to describe the Crown's conduct:

The Crown acknowledges that it acted unconscionably and in repeated breach of the principles of the Treaty of Waitangi in its dealings with Ngāi Tahu in the purchases of Ngāi Tahu land. The Crown further acknowledges that in relation to the deeds of

\footnotetext{
681 Te Maire Tau to OTS official 5, 29 July 1996, NE-12-027-00-04 Pt. 2, OTS archive, 2; CLO official 5 \& CLO official 6 to OTS official 5, 30 July 1996, NE-12-027-00-04 Pt. 2, OTS archive.

${ }^{682}$ OTS official 5 to CLO official 5 \& CLO official 6, 23 July 1996, NE-12-027-00-04 Pt. 2, OTS archive; OTS official 5 to Te Maire Tau \& Nick Davidson, 24 July 1996, NE-12-027-00-04 Pt. 2, OTS archive; OTS official 5 to OTS official 2, 28 August 1996, NE-12-027-00-04 Pt. 2, OTS archive.

${ }^{683}$ OTS official 5 to Te Maire Tau, 2 August 1996, NE-12-027-00-04 Pt. 2, OTS archive.

${ }^{684}$ Te Maire Tau to OTS official 5, 12 August 1996, NE-12-027-00-04 Pt. 2, OTS archive.
} 
purchase it has failed in most material respects to honour its obligations to Ngāi Tahu as its Treaty partner, while it also failed to set aside adequate lands for Ngāi Tahu's use, and to provide adequate economic and social resources for Ngāi Tahu. ${ }^{685}$

The most controversial position put forward by Crown Law was that the Crown had been responsible for keeping Ngāi Tahu in poverty, but that this poverty was relative to their previous state. ${ }^{686}$ This differed significantly from Ngāi Tahu viewpoints on the matter. The Crown Law historian's view of the "primitive” state of Ngāi Tahu before European contact was not an isolated contemporary interpretation of indigenous peoples. In Canada, British Columbian Chief Justice Alan McEachern made similar comments in the 1991 case of Delgamuukw v. the Queen in which he described the lives of British Columbian First Nations before the arrival of Europeans, specifically the Gitksan and Wet'suwet'en, as “nasty, brutish and short." ${ }^{687}$ New Zealand historian Paul Moon has also described the lives of most Māori in the decade preceding the signing of the Treaty of Waitangi, the 1830s, as "nasty, brutish and short.” ${ }^{688}$ The criticism of Crown Law (and indeed McEachern and Moon) is not to endorse the Eurocentric ideal of the “noble savage”, but to call into question Crown Law’s very colonial rationales. The CLO historian's view did not gain traction with OTS. The reference to the Crown failing to act in good faith and subsequently reducing Ngāi Tahu to poverty would remain and was expanded in the final version of the Apology:

The Crown recognises that it has failed to act towards Ngāi Tahu reasonably and with the utmost good faith in a manner consistent with the honour of the Crown. That failure is referred to in the Ngāi Tahu saying 'Te Hapa o Niu Tireni!' ('The unfulfilled promise of New Zealand') The Crown further recognises that its failure always to act in good faith deprived Ngāi Tahu of the opportunity to develop and kept the tribe for several generations in a state of poverty, a state referred to in the proverb 'Te mate o te iwi' ('The malaise of the tribe'). ${ }^{689}$

\footnotetext{
${ }^{685}$ Ngāi Tahu Deed of Settlement, 22 November 1997, 3. (my italics)

${ }^{686}$ CLO official 5 \& CLO official 6 to OTS official 5, 30 July 1996, NE-12-027-00-04 Pt. 2, OTS archive.

${ }^{687}$ The Honourable Chief Justice Allan McEachern, Delgamuukw et al. $v$ The Queen, "Reasons for Judgement." Smithers Registry No. 0843. 8 March 1991, 13.

${ }^{688}$ Paul Moon, Fatal Frontiers: a new history of New Zealand in the decade before the Treaty (Auckland: Penguin, 2006), 220.

${ }^{689}$ Ngāi Tahu Deed of Settlement, 22 November 1997, 3.
} 
The inclusion of a whakatauki (Māori proverb) within the apology was another important aspect of the apology. The former ToWPU Director had specifically included in the Waikato-Tainui apology wording that reflected the fact that Waikato-Tainui kuia had referred to having felt like "orphans” when their lands were confiscated by the Crown. ${ }^{690}$ Tau included in the Ngāi Tahu preamble a whakatauki to recognise all of those who had struggled for the resolution of Ngāi Tahu's claims since the middle of the nineteenth century:

The Crown makes this apology in recognition of the protracted labours of the Ngāi Tahu ancestors in pursuit of their claims for redress and compensation against the Crown over nearly 150 years, the length and persistence of which are alluded to in the Ngāi Tahu proverb 'He mahi kai takata, he mahi kai hoaka.' ${ }^{691}$ The Crown acknowledges their work and makes this apology to them and to their descendants. ${ }^{692}$

As the negotiations over the recitals continued this recognition of the work of those that had come before the current generation became a consistent concern for Ngāi Tahu's historians. By early August 1996 both groups of historians were nearly in complete agreement on all the aspects of the apology, the preamble, karakia and waiata. Then on 5 August Tau asked for another addition to the apology. ${ }^{693}$ He recommended that a part of Matiaha Tiramorehu's petition to Queen Victoria in 1857 be included to represent the visions that had been conceived by Ngāi Tahu once the truly oppressive onslaught of British colonisation and settlement occurred. "This was the command thy love laid upon these Governors...that the law be made one, that the commandments be made one, that the white skin be made just equal with the dark skin, and to lay down the love of thy graciousness to the Māori that they dwell happily...and remember the power of thy name.” The OTS Historian conceded to its proposed addition. ${ }^{694}$ The preamble and apology remained largely

\footnotetext{
${ }^{690}$ Frame, "Raupatu Settlement - Legal Finality and Political Reality,” 258.

691 "It is work that consumes people, as greenstone consumes sandstone."

692 Te Maire Tau to OTS official 5, 26 August 1996, NE-12-027-00-04 Pt. 2, OTS archive

${ }^{693}$ Te Maire Tau stated that Gabrielle Huria had given him the idea: Interview with Te Maire Tau, 5 May 2011.

${ }^{694}$ OTS official 5 to Tau, 8 August 1996, NE-12-027-00-04 Pt. 2, OTS archive, 3.
} 
the same and there was little further contention regarding historical debates within Ngāi Tahu's negotiations with the Crown.

\section{Conclusion}

The debates that took place during both Waikato-Tainui and Ngāi Tahu's negotiations revealed the very different historical interpretations of both the Crown and respective iwi regarding the history of Waikato-Tainui and Ngāi Tahu's claims. While OTS often led the negotiations, they were supported by the Crown Law Office which consistently attempted to limit the Crown’s legal liabilities. Waikato-Tainui and Ngāi Tahu on the other hand continually pressed the Crown to use more emotive terminology, and attempted to extend the boundaries of the historical interpretation of events. The negotiation of Waikato-Tainui's apology and preamble was more difficult since negotiators lacked the canon of a Tribunal report for referral and they were the first to construct a preamble to a modern Treaty settlement. Their negotiations regarding the preamble and apology also extended over a ten month period from October 1994 to August 1995, from the period before the signing of the Heads of Agreement, through to the Deed of Settlement and finally the settlement legislation. The negotiations regarding Ngāi Tahu's preamble and apology were negotiated relatively quickly within a three month period as the parties were able to use the Ngai Tahu Tribunal report to resolve any disagreements. Ngāi Tahu was unable to have the specific terminology originally sought in some cases, but obtained many concessions. Waikato-Tainui for its part failed to have specific mention of battles such as Rangiaowhia and Orakau placed into any of the preambles or apology, and the reference to the Sim Commission was inadequate from the point of view of Waikato-Tainui for the preamble to the Heads of Agreement and the 
settlement legislation. But the statement that Waikato-Tainui never rebelled was included in every preamble, and there was explicit recognition of the pain and suffering that war and confiscation had wrought. The preambles and apologies of Waikato-Tainui and Ngāi Tahu’s settlements represented debates over not only the history of their respective claims, but also the Crown’s sovereignty and Ngāi Tahu and Waikato-Tainui rangatiratanga. 


\section{Conclusion}

Waikato-Tainui and Ngāi Tahu’s Treaty settlement negotiations with the Crown symbolised in many ways the inherent tension that was and continues to be at the centre of the Treaty of Waitangi relationship between Māori and the Crown-the balance between the Māori right to tino rangatiratanga or self-determination and the Crown's right to governor its kawanatanga. For Ngāi Tahu and Waikato-Tainui, the pursuit of rangatiratanga dominated nearly all of their negotiating positions. On the other hand, the Crown stressed throughout both negotiations that settlements would be limited by the practicalities of the Crown's governance. Above all, there were legal, political and economic limitations that governed the parameters of the negotiations as a whole. These limitations fed into the final product of the negotiations in terms of the political recognition that was achieved by both Ngāi Tahu and Waikato-Tainui, the size of the financial compensation provided, the amount of land and form in which it was returned, and the historical accounts and apologies that accompanied both settlements.

Waikato-Tainui and Ngāi Tahu took very different paths to negotiation, although both iwi submitted their claims to the Waitangi Tribunal at approximately the same time in 1986 and 1987. Waikato-Tainui chose to proceed directly to negotiations with the Crown without a Tribunal hearing but attempted to turn to the Tribunal whenever their negotiations stalled. Waikato-Tainui’s negotiations began in the middle of 1989 with the Fourth Labour government. Waikato-Tainui was engaged in negotiations with the Labour government for just over a year until an offer was made to the iwi in September 1990, but Waikato-Tainui rejected that offer as it was limited and would have done little to enhance Waikato-Tainui's rangatiratanga. Negotiations resumed with the Fourth National government in 1991 and proceeded slowly as some Crown lands, Hopuhopu and Te Rapa, were transferred to 
Waikato-Tainui between 1991 and 1993 while the Crown developed its Treaty settlement policy. A Heads of Agreement was signed in December 1994, and a final Deed of Settlement in May 1995. Before Ngāi Tahu’s negotiations commenced with the Fourth National government in September 1991, Ngāi Tahu had their claims heard by the Waitangi Tribunal from 1987 to 1989. Ngāi Tahu's negotiations with National were split in two distinct sections from 1991 to 1994 and from 1996 to 1997, with a breakdown in the negotiations from December 1994 to April 1996. Ngāi Tahu signed a Heads of Agreement with the Crown in October 1996 and a final Deed of Settlement in November 1997.

The Crown, first under the Fourth Labour government and for the large part under the Fourth National government, gradually developed its Treaty settlement policy during the late 1980s and the first half of the 1990s. While the pace of negotiations was relatively quick in comparison to Treaty settlement negotiations in the United States, Canada, or Australia, Waikato-Tainui negotiators were pressured by their constituency to complete a settlement as quickly as possible. The years of delay that resulted from the policy development process pressed hard on the Waikato-Tainui negotiating team. While the Minister in Charge of Treaty of Waitangi Negotiations, Doug Graham, and the Prime Minister, Jim Bolger, were supportive of settlements there was Cabinet level opposition, in addition to the policy development process that contributed to the delays. These issues were evidence of the political nature of the settlement process and the Crown's overriding control of the negotiations. Throughout their negotiations Waikato-Tainui remained focused on the return of land as their key negotiating principle. Following the initial negotiations with the Labour government from 1989-1990, the National government offered Waikato-Tainui the return of the Hopuhopu Army Base in 1991. Waikato-Tainui’s early negotiations with the National government were dominated by the return of Hopuhopu in 1991 and Te Rapa in 1993 while 
the wider parameters of a settlement were slowly negotiated from 1991-1994. The return of Hopuhopu (and Te Rapa) was further complicated by opposition from hapū within WaikatoTainui who wished to have the assets and lands returned directly to the local hapū, Ngāti Whawhakia and Ngāti Wairere.

Ngāi Tahu’s earliest negotiations with the National government in late 1991 and early 1992 were marked by the development of Ngāi Tahu’s legal personality. The Ngāi Tahu Māori Trust Board, which had been established in 1944 to manage and distribute the compensation from their 1940s settlement, was viewed by Ngāi Tahu as impinging on their rangatiratanga as the Trust Board was ultimately accountable to the Minister of Māori Affairs rather than the Ngāi Tahu people. Ngāi Tahu's most pressing concern was the establishment of an organisation that would serve Ngāi Tahu tribal members without any interference from the Crown. Negotiations with the Crown regarding the development of Ngāi Tahu's legal personality took place from late 1991 to mid-1993. While Ngāi Tahu viewed the new entity that would govern Ngāi Tahu members as an embodiment of Ngāi Tahu's reaffirmed rangatiratanga, there was opposition by the Crown to the use of rangatiratanga terminology. Eventually an agreement was reached which minimised some of the Crown's concerns that the word "rangatiratanga" would be entrenched in legislation. In 1993 legislation was introduced to Parliament to establish a new organisation to represent and govern Ngāi Tahu—the Te Rūnanga o Ngāi Tahu Bill.

By mid-1993 Ngāi Tahu had the Crown’s support to develop Te Rūnanga o Ngāi Tahu, but there remained opposition from some hapū and constituent iwi within Ngāi Tahu such as Ngāti Mamoe, Waitaha and Tuhuru to the establishment of an iwi-based organisation. Auckland Central MP Sandra Lee and Southern Māori MP Whetu Tirikatene-Sullivan, on behalf of Ngāti Mamoe, Waitaha and Tuhuru, delayed the establishment of Ngāi Tahu’s legal 
personality until 1996. These hapū claimed that Te Rūnanga o Ngāi Tahu would undermine the sovereignty of their hapū and they sought legal personality legislation of their own. Although both Waikato and Ngāi Tahu negotiators’ positions were buttressed by the Crown’s focus on iwi-level negotiators, the Crown's prevailing domination of the wider process created a tenuous political environment within each iwi in terms of hapū dissent. The emphasis on iwi-level negotiators, and later Large Natural Groupings, served to disempower hapū. ${ }^{695}$ The Crown's control of the negotiations extended from the political sphere to the determination of financial compensation.

The financial aspects of both Waikato-Tainui and Ngāi Tahu's settlements were heavily influenced by the Crown's own limitations in terms of the need to negotiate settlements that would be in the best interests of all New Zealanders. If either Ngāi Tahu or Waikato-Tainui were fully compensated for their losses, then the nation would be bankrupted. The Crown made it clear that settlements would be political agreements that would be based on no more than, as Graham had put it, "an inside feeling that it is fair.” ${ }^{696}$ In such an environment a justification of the amount of compensation provided was going to be extremely difficult. The methodology for calculating the respective losses of Waikato-Tainui and Ngāi Tahu were governed by their negotiating principles. Waikato-Tainui’s compensation was focused on the return of land, while Ngāi Tahu was focused on compensation that was tied to the substantial reserves that Ngāi Tahu claimed should have been awarded during the large land purchases of the 1840s to $1860 \mathrm{~s}$.

Early in their negotiations with the National government in 1992, Ngāi Tahu were pressed by the Crown to formulate a settlement proposal. Based on the key negotiating principle that Ngāi Tahu should have been reserved one tenth of the land that had been sold,

${ }^{695}$ Cowie, "The Treaty Settlement Process," 51.

696 "Meeting of Ngāi Tahu and Crown negotiators," 11 February 1992, C-27-2-03 Vol.1, OTS archive, 2. 
in early February 1992 Ngāi Tahu negotiators proposed a settlement that reflected the current land value of one tenth of the area of land sold between 1844 and 1864, \$1.3 billion or one tenth of $\$ 13$ billion. The Crown responded with a settlement valued at $\$ 100$ million that was unconnected to any formulation or methodology. Following the Crown's rejection of Ngāi Tahu's settlement proposal, the negotiations regarding financial compensation stalled and were overtaken by the fisheries settlement and the establishment of the fiscal cap for all settlements in September 1992. From September 1992 to December 1994 the Crown gradually developed its new proposals for Treaty settlements that entrenched the fisheries settlement’s \$170 million benchmark and eventually set the total cap of \$1 billion for all settlements. Both Ngāi Tahu and Waikato-Tainui had to adjust their financial expectations so that their respective settlements would fit within the Crown's newly set fiscal parameterswhat was dubbed at the time as the "fiscal envelope.” While both Waikato-Tainui and Ngāi Tahu were affected by the fiscal envelope proposal—both settlements were nominally worth \$170 million-Waikato-Tainui’s settlement was signed right when the Crown’s proposals for Treaty settlements were released. Waikato-Tainui struggled to publically separate their settlement from the Crown's fiscal envelope policy and its rangatiratanga was challenged by other iwi who felt that Waikato-Tainui had accepted the Crown's offer too easily.

Although the Crown established the fiscal parameters of settlement, Waikato-Tainui and Ngāi Tahu were both able to negotiate settlement instruments that allowed each iwi to expand beyond the limits of the fiscal envelope and the $\$ 170$ million benchmark. The provision of interest on the unpaid sum of compensation, the Right of First Refusal and Deferred Selection Process mechanisms for the purchasing of Crown lands (in Ngāi Tahu’s case), and the negotiation of relativity clauses provided Ngāi Tahu and Waikato-Tainui with the ability to stretch their nominal quantums of $\$ 170$ million far beyond that figure. While the 
Crown's kawanatanga or right to govern was entrenched by the establishment of the fiscal envelope policy, both iwi were able to assert some aspect of their rangatiratanga by negotiating these important financial instruments. They allowed both iwi to more confidently take their settlement packages back to their people to approve the settlements.

The political and economic parameters of the negotiations also influenced the amount of land that was returned to both iwi and the manner in which lands were returned. The Crown's overriding domination of the wider context of the negotiations was affected not only by Waikato-Tainui and Ngāi Tahu's efforts to affirm their rangatiratanga by negotiating the return of as much land as possible, but by third-party interests such as conservationists and the former owners of Crown land taken under the Public Works Act. These third-parties affected the return of specific lands in both negotiations.

Ngāi Tahu sought the return of specific culturally significant lands in fee simple title such as the Crown Titi Islands, Whenua Hou (Codfish Island), Rarotoka Island, the Arahura Valley, the bed of Lake Waihora and others. Where the return of lands in fee simple title was not possible, co-management arrangements were sought. Waikato-Tainui sought the return of lands in a form of inalienable customary title that would, in theory, protect the land from the powers of the Public Works Act and other land-taking legislation. For Ngāi Tahu the provision of land in fee simple title was adequate to ensure Ngāi Tahu control of those lands. Although Waikato-Tainui and Ngāi Tahu differed in their preferred mechanisms for the return of lands, both iwi sought the return of Crown land without marginal strips and advocated for increased control over whatever settlement assets and land was returned.

The final chapter of this thesis investigated the negotiations regarding the formulation of the preambles to each settlement and the Crown apologies provided to Waikato-Tainui and Ngāi Tahu. These negotiations, like the discussions regarding the politics, economics and 
land aspects of each settlement, had at their centre the tension between Waikato-Tainui and Ngāi Tahu’s rangatiratanga and the Crown's defence of its own sovereignty and role as the governing power. The negotiations revealed the differing historical views that iwi negotiators and advisors held in contrast to Crown Ministers and officials, but they ultimately revealed a shared sense of historical understanding. The discussions and disagreements could often focus on the use of specific terminology that could even question the Crown's own sovereignty. Ngāi Tahu and Waikato-Tainui negotiators and advisors pressed throughout their respective negotiations for specific recognition of the historical context under which their claims were settled. Although the Crown ultimately controlled the process under which the preambles and apologies were produced, there was a significant aspect of Waikato-Tainui and Ngāi Tahu agency in the changes that were achieved for each preamble and apology.

Waikato-Tainui was the first iwi to have a preamble and apology included in their settlement and subsequently the negotiation over these aspects of their settlement extended over many months. Without the canon of a Tribunal report, Waikato-Tainui and the Crown were also unable to refer to an agreed upon text to break deadlocks and solve disagreements. Ngāi Tahu and the Crown on the other hand were able to refer to the various Ngāi Tahu Tribunal reports and research reports produced for the Tribunal hearing whenever any major differences between the parties surfaced. Both iwi placed considerable importance on the value of their preambles and apologies, but that is not the case for all iwi who have settled. The Crown's policy is that without an apology, a settlement is not possible. Other iwi negotiators have sought the inclusion of specific historic Crown officials in their historical account, but the Crown has only allowed references to general Crown policy and historical figures at a high level such as Governors and Ministers of Native Affairs. These different 
conceptions of the importance of historical accounts and apologies reveal the widely diverging views within Māoridom on the topic.

The contribution of this thesis lies in its investigation of the first two major Treaty settlements concluded in the modern era of Treaty settlement negotiations in New ZealandWaikato-Tainui’s settlement in 1995 and Ngāi Tahu’s settlement in 1997. The existing historiography has addressed these two settlements in very brief detail, and this is the first in depth study of the negotiation process from the point of view of both the Crown and Ngāi Tahu and Waikato-Tainui. This improved understanding of Treaty settlement processes, and specifically the first two pioneering settlements in the modern era, allows for a greater awareness of the difficulties and intricacies of the negotiation process for both Māori and the Crown.

In the end all parties would have felt that some measure of victory had been gained by the end of their negotiations. The Crown had settled two sets of major claims and established precedents to govern the Treaty settlement process for over fifteen years. The Crown had introduced a level of economic and political certainty from two previously obstructive iwi that had used legal, political and social means over the years to obtain their settlements.The Crown had cemented its governance and thereby strengthened its kawanatanga, yet had also given some key concessions. Waikato-Tainui and Ngāi Tahu were able to regain a measure of rangatiratanga through the return of land and compensation, for Ngai Tahu the development of Te Rūnanga o Ngai Tahu, and in general were able to increase their political influence and power regionally through their economic clout. The negotiation of the relativity clauses was especially important as they challenged the Crown's financial certainty. Just as the Crown’s kawanatanga was challenged, so too was Waikato-Tainui and Ngai Tahu's rangatiratanga, although the Crown's sovereignty remained strongly in place. Their claims were now settled 
and the negotiations took place largely within the Crown's tight parameters. Ultimately, both Ngai Tahu and Waikato-Tainui rangatiratanga and the Crown’s kawanatanga were simultaneously challenged and enhanced by the negotations.

This study has highlighted the importance of Waikato-Tainui and Ngāi Tahu rangatiratanga within the Treaty settlement process, and the Crown's focus on maintaining its kawanatanga or right to govern. The rangatiratanga-kawanatanga paradigm allows for a greater appreciation of the motivations pushing and pulling Waikato-Tainui, Ngāi Tahu and the Crown in the positions and actions each group took during the negotiations. This increased knowledge of the motivations of Waikato-Tainui, Ngāi Tahu and the Crown enables a better awareness of the intricate and complex Treaty settlement process. The focus on a rangatiratanga and kawanatanga interpretation has allowed for a greater understanding of Treaty settlement negotiations, because it was the clash between rangatiratanga and kawanatanga that first created the historical context of Māori grievances and ultimately Treaty settlements. 


\title{
Select Bibliography
}

\author{
Primary Sources
}

Archives

Doug Graham Collection

Archives New Zealand (Wellington)

AAKW W5105 7812 Series

Ngai Tahu negotiations

Treaty of Waitangi Policy Unit (ToWPU, 1989-1994), Wellington

C-27 series

OTS (1995-), Wellington

Negotiations (NE), Settlement Legislation (SL) series

Macmillan Brown Ngai Tahu Archives (1988-1998), Christchurch

NT140, MB140 series

Te Rūnanga o Ngai Tahu archives (1991-1998), Christchurch

Vh series

Waikato-Tainui negotiations

ToWPU (1989-1994), Wellington

TC-30 series

OTS (1995-), Wellington

Implementation (IM), Negotiations (NE) series

Waikato-Tainui College of Research \& Development Raupatu Archives, Hopuhopu

Raupatu Correspondence (RC) series 


\section{Deeds of Settlement}

Fisheries Deed of Settlement, 23 September 1992.

Waikato-Tainui Deed of Settlement, 1995.

Ngai Tahu Deed of Settlement, 1997.

Ngati Turangitukua Deed of Settlement, 1998.

\section{Interviews}

\section{Crown}

ToWPU official 1

ToWPU official 3

ToWPU official 4

ToWPU official 6

CLO official 6

Alex Frame

Sir Douglas Graham

TPK official/OTS Director

Treasury official 10

\section{Ngai Tahu}

Sid Ashton

Anake Goodall

Richard Meade

Sir Tipene O’Regan

Te Maire Tau 


\section{Waikato-Tainui}

Denese Hanare

Nanaia Mahuta

Shane Solomon

Brent Wheeler

\section{Legislation}

South Island Landless Natives Act 1906

Ngai Tahu Claim Settlement Act 1944

Ngai Tahu Māori Trust Board Act 1946

Waikato-Maniapoto Māori Claims Settlement Act 1946

Māori Trust Boards Act 1955

Treaty of Waitangi Act 1975

Reserves Act 1977

Public Works Act 1981

Treaty of Waitangi Amendment Act 1985

State Owned Enterprises Act 1986

Treaty of Waitangi (State Enterprises) Act 1988

Crown Forest Assets Act 1989

Waikato-Tainui Claims Settlement Act 1995

Te Rūnanga o Ngāi Tahu Act 1996

Ngāi Tahu Claims Settlement Act 1998

Māori Fisheries Act 2004 


\section{Litigation}

NZMC v. Attorney-General (1987)

Tainui Maaori Trust Board v Attorney-General [1989] 2 NZLR 513

4 South Island Appellate Court Minute Book 673 Folio 6/3 [1990]

The Honourable Chief Justice Allan McEachern, Delgamuukw et al. v The Queen, "Reasons for Judgement.” Smithers Registry No. 0843. 8 March 1991, 13.

Berryman v Te Arikinui Te Atairangikaahu - Hopuhopu Military Camp and Te Rapa Airforce Base (1993), 18 Waikato Maniapoto Appellate MB 173.

August Daniel Deane v. Attorney-General \& Henry Michael Horton and Barrie McCormick Campbell as trustees of the EG Levin Farm Settlement Trust v. Attorney-General (1996)

Haronga v Waitangi Tribunal and others (SC54/2010) [2011] NZSC 53 


\section{Newspapers and Periodicals}

The Dominion (Wellington)

Evening Post (Wellington)

Kia Hiwa Raa

The Listener

Mana Magazine

New Zealand Herald (Auckland)

Otago Daily Times (Dunedin)

Te Karaka

The Press (Christchurch)

Sunday Star Times (Auckland)

Waikato Times

\section{Unofficial documents}

Appendix to the Journals of the House of Representatives, "Further Papers Relative to Confiscated Lands,” 1873 Session I, C-04B.

Department of Justice, Principles for Crown Action on the Treaty of Waitangi, 1989.

Hill, Richard. Enthroning "justice above might"? : the Sim Commission, Tainui and the Crown. Wellington: Treaty of Waitangi Policy Unit, Dept. of Justice, 1989.

---------. Settlements of major Māori claims in the 1940s : a preliminary historical investigation. Wellington: Treaty of Waitangi Policy Unit, Dept. of Justice, 1989.

Office of Treaty Settlements. Crown proposals for the settlement of Treaty of Waitangi claims: detailed proposals; summary. Wellington: Office of Treaty Settlements, 1994.

Te Puni Kōkiri. Crown proposals for the settlement of Treaty of Waitangi Claims: consultation with Māori. Wellington: Te Puni Kōkiri, 1994. 


\section{Secondary Sources}

\section{Articles, books, theses}

Alves, Dora. The Mãori and the Crown: an Indigenous people's struggle for selfdetermination. Westport, Conn.: Greenword Press, 1999.

Anderson, Atholl. Te Puoho`s Last Raid. Dunedin: Otago Heritage Books, 1986.

Archie, Carol, ed. Māori sovereignty: the Pākehā perspective. Auckland: Hodder Moa Beckett, 1995.

--------. Skin to Skin: Intimate, True Stories of Māori-Pākehā Relationships. Auckland: Penguin, 2005.

Baker, H.R.. From Treaty to conspiracy: (a theory). Palmerston North: The Foundation, 1998.

Barkan, Elazar. The Guilt of Nations: Restitution and Negotiating Historical Injustices. New York: W. W Norton \& Co., 2000.

Belgrave, Michael. Historical frictions: Māori claims and reinvented histories. Auckland: Auckland University Press, 2005.

Belgrave, Michael, et al., (eds.) Waitangi revisited: perspectives on the Treaty of Waitangi. Auckland: Oxford University Press, 2005.

Belich, James. The New Zealand Wars and the Victorian interpretation of racial conflict. Auckland: Penguin, 1988.

--------. Paradise Reforged: a history of the New Zealanders from the 1880s to the year 2000. Allan Lane: Penguin, 2001.

--------. Making peoples: a history of the New Zealanders from Polynesian settlement to the end of the nineteenth century. North Shore: Penguin, 2007.

Bell, Rachael. “'Texts and Translations,' Ruth Ross and the Treaty of Waitangi,” New Zealand Journal of History, 43, 1 (2009).

Bellingham, Julie. "The Office of Treaty Settlements and Treaty history: an historiographical study of the historical accounts, acknowledgements and apologies written by the Crown, 1992 to 2003.” M.A. Thesis: VUW, 2006.

Binney, Judith. The Legacy of Guilt, A Life of Thomas Kendall. Auckland: Oxford University Press, 1968. 
Binney, Judith, Chaplin, Gillian and Wallace, Craig. Mihaia: The Prophet Rua Kenana and his community at Maungapohatu. Auckland: Oxford University Press, 1979.

Blackburn Carole, "Producing legitimacy: reconciliation and the negotiation of aboriginal rights in Canada,” Journal of the Royal Anthropological Institute, 13, 621-638.

---------. "Searching for Guarantees in the Midst of Uncertainty: Negotiating Aboriginal Rights and Title in British Columbia,” American Anthropologist, Vol. 107, 4, 586-596.

Boast, Richard. The Native Land Court: A Historical Study, Cases and Commentary, 18621887. Auckland: Thomson Reuters, 2013.

Boast, Richard and Richard Hill, eds. Raupatu: The Confiscation of Māori Land. Wellington: Victoria University Press, 2009.

Bolger, Jim. A View from the Top. Auckland: Viking Press, 1998.

Brookfield, Jock. Waitangi \& Indigenous Rights: Revolution, Law \& Legitimation. Auckland: Auckland University Press, 1999.

Brooking, Tom. “'Busting Up’ The Greatest Estate of All: Liberal Māori Land Policy, 18911911,” New Zealand Journal of History, vol. 26, no. 1, 1992, 78-98.

The History of New Zealand. Westport: Greenwood Press, 2004.

Brooks, Roy L. (ed.). When Sorry Isn't Enough: The Controversy Over Apologies and Reparations for Human Injustice. New York University: New York, 1999.

Byrnes, Giselle. The Waitangi Tribunal and New Zealand history. Auckland: Oxford University Press, 2004.

--------. “By Which Standards? History and the Waitangi Tribunal: A Reply,” New Zealand Journal of History, 40, 2 (2006), 214-229.

--------. (ed.), The New Oxford History of New Zealand. Oxford: Oxford University Press, 2009.

Byrnes, Giselle and David Ritter. "Antipodean Settler Societies and their Complexities: the Waitangi Process in New Zealand and Native Title and the Stolen Generations in Australia," Commonwealth \& Comparative Politics, Vol. 46, No. 1, 54-78.

EH Carr and Richard Evans, What is History? (London: Palgrave, 2001), 30.

Christie, Walter. Treaty Issues. Christchurch: Wyvern Press, 1997.

--------. A Race Apart. Auckland: Wyvern Press, 1998.

Clark, Margaret, ed. The Bolger Years: 1990-1997. Wellington, 2008. 
Coates, Ken S. and Paul G. McHugh, eds. Living relationships = Kōkiri ngatahi: the Treaty of Waitangi in the new millenium. Wellington: Victoria University Press, 1998.

Cookson J. and Dunstall G. (eds.). Southern Capital, Christchurch: Towards a City Biography (Christchurch: Canterbury University Press, 2000).

Crocker, Therese. "Introduction: Principles for Crown Action on the Treaty of Waitangi, 1989.” Treaty of Waitangi Research Unit, Historical Document Series 6, Wellington, 2011.

Cunningham, Michael. “Saying Sorry: The Politics of Apology.” The Political Quarterly, v. 70, 1999.

-------. "Prisoners of the Japanese and the Politics of Apology: A Battle Over History and Memory.” Journal of Contemporary History, v. 39, no. 4, 2004.

Diamond, Paul, ed. A Fire in Your Belly. Wellington: Huia, 2003.

Dominy, Michele D. "White Settler Assertions of Native Status,” American Ethnologist, Vol. 22, No. 2 (May, 1995), 358-374.

Durie, Mason. Te mana, te kawanatanga: the politics of Māori self-determination. Auckland: Oxford University Press, 1998.

Evans, Richard J.. In Defence of History. London: Palgrave, 1997.

Evison, Harry C. Ngai Tahu Land Rights and the Crown Pastoral Lease Lands in the South Island of New Zealand. Christchurch, 1986-1987 (3 Vols.).

--------. Ngai Tahu Land Rights Supplements. Christchurch: 1986.

---------, ed. The Treaty of Waitangi and the Ngai Tahu Claim, Christchurch, 1988.

---------. The Treaty of Waitangi and the Waitangi Tribunal: Fact and Fiction, Christchurch, 1989-1990 (2 Vols.).

--------. Ta Wai Pounamu, the greenstone island: a history of the Southern Mãori during the European colonization of New Zealand. Christchurch: Aoraki Press, 1993.

--------. The Long Dispute: Māori land rights and European colonisation in Southern NZ. Christhchurch, 1997;

--------. The Ngai Tahu deeds: a window on New Zealand history. Christchurch: Canterbury University Press, 2006.

--------. New Zealand Racism in the Making: The Life \& Times of Walter Mantell. Lower Hutt: Panuitia Press, 2010.

Flanders, Nicholas. "The Alaska Native Corporation as Conglomerate: The Problem of Profitability,” Human Organisation, Vol. 48 Number 4, Winter 1989, 299-312. 
Furniss, Elisabeth. Burden of History: Colonialism and the Frontier Myth in a Rural Community. Vancouver: UBC Press, 1999.

Gardiner, Wira. Return to Sender: What really happened at the fiscal envelope hui. Auckland: Reed Books, 1996.

Gibbs, Meredith. “Are New Zealand Treaty of Watangi settlements achieving justice? The Ngai Tahu settlement and the return of Pounamu (greenstone). Thesis (Ph. D.)--University of Otago, 2001.

Graham, Douglas. Trick or Treaty? Wellington: Institute for Policy Studies, 1997.

Harris, Aroha. Hikoi: Forty Years of Māori Protest. Wellington: Huia Publishers, 2004.

Hayward, Janine Alyth Deaker. "In search of a Treaty partner: who, or what, is the Crown?" Thesis (Ph.D.)--Victoria University of Wellington, 1995.

Hayward, Janine. “Three's a Crowd?: The Treaty of Waitangi, the Waitangi Tribunal, and Third Parties” New Zealand Universities Law Review, 20(2): 239-251 (2002).

Hayward, Janine \& Nicola R. Wheen, eds. The Waitangi Tribunal: Te Roopu Whakamana i te Tiriti o Waitangi. Wellington: Bridget Williams Books, 2004.

Highman, Alexandra Emma-Jane. "Te Iwi of Ngai Tahu: An Examination of Ngai Tahu’s Approach to, and Internal Expression of, Tino Rangatiratanga.” M.A Thesis, University of Canterbury, 1997.

Hill, Richard. Anti-treatyism and anti-scholarship: an analysis of anti-treatyist writings. Wellington: Stout Research Centre, VUW, 2002.

--------. State Authority, Indigenous Autonomy in New Zealand/Aotearoa, 1900-1950. Wellington: Victoria University Press, 2004.

Māori and the State: Crown-Māori Relations in New Zealand/Aotearoa, 1950-2000. Wellington: Victoria University Press, 2009.

---------. “Historical 'Facts' and the Waikato Raupatu Claims Settlement Act 1995,” Stout Centre Treaty Research Series, 2014.

Hill, Richard and Brigitte Bonisch-Brednich. 'Politicizing the Past: Indigenous Scholarship and Crown-Māori Reparations Processes in New Zealand,“ Social and Legal Studies, (2007), 163-181.

Hill, Richard and Richard Boast, eds. Raupatu: The Confiscation of Māori Land. Wellington, Victoria University Press, 2009.

Hill, Richard and Vincent O’Malley. The Māori quest for rangatiratanga/autonomy, 18402000. Wellington: Stout Research Centre, VUW, 2000. 
Johnson, Miranda. “Making History Public: Indigenous Claims to Settler States,” Public Culture, 20:1, 97-117.

---------. "Honest acts and dangerous supplements: Indigenous oral history and historical practice in settler societies,” Postcolonial Studies, Vol. 8, No. 3, 261-276.

Joseph, Robert. 'The Government of Themselves: Indigenous Peoples' Internal SelfDetermination, Effective Self-Governance and Authentic Representation: Waikato-Tainui, Ngai Tahu and Nisga’a.' Ph.D Thesis (Law), University of Waikato, 2006.

Kawharu, I.H., ed. Waitangi: Māori and Pākehā perspectives of the Treaty of Waitangi. Auckland: Oxford University Press, 1989.

Keenan, Danny. Wars Without End: The Land Wars in Nineteenth Century New Zealand. Auckland: Penguin, 2009.

Kelly, Stephanie. "The Ngai Tahu Māori Trust Board.” University of Canterbury, MA Thesis, 1991.

Kelsey, Jane. A Question of Honour? Labour and the Treaty, 1984-1989. Wellington: Allen \& Unwin, 1990.

King, Michael. Whina. Auckland: Hodder \& Stoughton, 1983.

--------. Te Puea: A life. Auckland: Reed Publishing, 2003, $4^{\text {th }}$ ed., orig. 1978.

---------. The Penguin History of New Zealand. Auckland: Penguin, 2003.

Kirkwood, Carmen. Te Arikinui and the Millenium of Waikato. Ngāruawāhia: Turongo House, 2001.

Langton Marcia et al., eds. Honour Among Nations: Treaties and Agreements with Indigenous People. Melbourne: Melbourne University Press, 2004.

Lawrence, David “Managing Parks/Managing 'Country': Joint Management of Aboriginal Owned Protected Areas in Australia,” Research Paper 2 1996-97, Parliament of Australia.

Litchfield, Michael. “The Confiscation of Māori Land,” VUW Law Review Vol. 15 No. 4 1985, 337-362.

Locke, Cybele. Workers in the Margins: Union Radicals in Post-War New Zealand.

Wellington: Bridget Williams Books, 2012.

Macdonald, Robert. The Fifth Wind. Auckland: Hodder \& Stoughton, 1989.

McAloon, Jim. “By Which Standards? History and the Waitangi Tribunal,” New Zealand Journal of History, 40, 2 (2006), 194-213.

McCan, David. Whatiwhatihoe: the Waikato raupatu claim. Wellington: Huia, 2001. 
McHugh, Paul G.. The Mãori Magna Carta: New Zealand law and the Treaty of Waitangi. Auckland: Oxford University Press, 1991.

McIntyre, Roberta. Whose high country? A history of the South Island high country of New Zealand. Auckland: Penguin, 2008.

McKinnon, Malcolm. Treasury: The New Zealand Treasury, 1840-2000. Auckland: Auckland University Press, 2003.

McLay, Geoff, ed. Treaty settlements: the Unfinished business. Wellington: N.Z. Institute of Advanced Legal Studies and Victoria University of Wellington Law Review, 1995.

Mason, Maika and Beck, Russell. Pounamu Treasures: Nga Taonga Pounamu (Auckland: Penguin, 2012)

Mead, Hirini Moko and Grove, Neil. Nga pepeha a nga tupuna. Wellington: Victoria University Press, 2001.

Mein Smith, Philippa. A Concise History of New Zealand. Cambridge: Cambridge University Press, 2005.

Melbourne, Hineani, ed. Māori sovereignty: the Māori perspective. Auckland: Hodder Moa Beckett, 1995.

Metge, Joan and Kinloch, Patricia. Talking Past Each Other (Wellington:Victoria University Press, 1978).

Mikaere, Annie. “Settlement of Treaty Claims: Full and Final, or Fatally Flawed?” New Zealand Universities Review, 17, 2 (1997).

Mills, Keri. “The Changing Relationship between Māori and Environmentalists in 1970s and 1980s New Zealand,” History Compass 7/3 (2009): 678-700.

Minogue, Kenneth. 'Aborigines and Australian Apologetics.' Quadrant, September 1998, 1120.

--------. Waitangi: morality and reality. Wellington: New Zealand Business Roundtable, 1998.

Moon, Paul. The occupation of Moutoa Gardens. Auckland: Auckland Institute of Technology, 1996.

---------. The Sealord Deal. Palmerston North: Campus Press, 1999.

---------. “The Creation of the 'Sealord Deal',” The Journal of the Polynesian Society, Vol. 107 No. 21998.

Moon, Paul. Fatal Frontiers: a new history of New Zealand in the decade before the Treaty. Auckland: Penguin, 2006. 
Muirhead, Gavin. Footprints in the future. Wellington: Landcorp, 2009.

Mulholland, Malcolm, ed. State of the Māori Nation: twenty-first century issues in Aotearoa. Auckland: Reed, 2006.

Mutu, Margaret. “The Role of History and Oral Traditions in Regaining Fagin’s Ill-gotten Gains: Settling Ngati Kahu's Treaty of Waitangi Claims Against the Crown.” Te Pouhere Korero 3: Māori History, Māori People, 23-44.

--------. The State of Māori Rights. Wellington: Huia, 2011.

Nobles, Melissa. The Politics of Official Apologies. New York: Cambridge University Press, 2008.

O’Malley, Vincent, Stirling, Bruce and Penetito, Wally (eds.), The Treaty of Waitangi Companion: Māori and Pākehā from Tasman to Today. Auckland: Auckland University Press, 2010.

--------. “Choosing Peace or War: The 1863 Invasion of Waikato.” New Zealand Journal of History, Vol.47, No.1, 2013.

--------. Beyond the Imperial Frontier: The Contest for Colonial New Zealand. Wellington: Bridget Williams Books, 2014.

O'Regan, Tipene. “Old Myths and New Politics: Some Contemporary Uses of Traditional History.” New Zealand Journal of History, 26(1), April 1992.

Oliver, W.H.. Claims to the Waitangi Tribunal. Wellington: Waitangi Tribunal Division, Department of Justice, 1991.

---------. “Pandora’s envelope: it’s all about power.” New Zealand Books, March 1995.

---------. “Getting facts on your side.” NZ Review of Books, May 1995.

--------.. Looking for the Phoenix: A Memoir. Wellington: Bridget Williams Books, 2002.

---------. “A Reply To Jim McAloon.” New Zealand Journal of History, 41, 1 (2007), 83-87.

Orange, Claudia. The Treaty of Waitangi. Wellington: Allen \& Unwin, 1987.

---------. An Illustrated History of the Treaty of Waitangi. Bridget Williams Books:

Wellington, 2004.

Palmer, Geoffrey. Reform: A Memoir. Wellington: Victoria University Press, 2013.

Parsonson, Ann. “Te mana o te Kīngitanga Māori: a study of Waikato-Ngatimaniapoto relations during the struggle for the King Country, 1878-1884.” MA thesis, University of Canterbury, 1972. 
"He Whenua Te Utu (The Payment will be Land).” PhD thesis, University of Canterbury, 1978.

. "Evidence of Dr Ann R Parsonson on the Otakou tenths.” Report for Ngai Tahu claimants in the Ngai Tahu Waitangi Tribunal inquiry, C1, 1987.

Pihama, Leonie, ed. The Fiscal Envelope: economics, politics \& colonisation, Vol.1. Auckland: Moko Productions, RUME, 1995.

Price, Richard. The Politics of modern history-making: the 1990s negotiations of the Ngai Tahu tribe with the Crown to achieve a Treaty of Waitangi claims settlement, Macmillan Brown Research Series, 1994.

Ratcliffe, Greg, ed. Compr(om)ising Postcolonialism(s): Challenging Narratives and Practices, edited by Dr Greg Ratcliffe. Portsmouth, New Hampshire: Dangaroo Press, 2002.

Regan, Paulette. “A Transformative Framework for Decolonizing Canada: A Non-Indigenous Approach,” Presented at the IGOV Doctoral Student Symposium, 20 January 2005.

Rose, Alex. Spirit Dance at Meziadin: Chief Joseph Gosnell and the Nisga'a Treaty. Vancouver, 2000.

Ross, Ruth. “Te Tiriti o Waitangi: Texts and Translations,” New Zealand Journal of History, 6, 2 (1972).

Ruru, Jacinta, ed. "In Good Faith" Symposium, Proceedings marking the $20^{\text {th }}$ anniversary of the Lands case. Dunedin: University of Otago and the Law Foundation NZ, 2008.

Schwimmer, Erik, ed. The Māori people in the nineteen-sixties. Auckland: Hurst, 1968.

Seuffert, Nan. "Nation as Partnership: Law, 'Race', and Gender in Aotearoa New Zealand's Treaty Settlements.” Law \& Society Review, Vol. 39, No. 3 (Sep. 2005), 485-526.

Sharp, Andrew. Justice and the Māori: the philosophy and practice of Māori claims in New Zealand since the 1970s. Auckland: Oxford University Press, 1997.

Sharp, Andrew and Paul McHugh. (eds.) Histories, power and loss: uses of the past: a New Zealand commentary. Wellington: Bridget Williams Books, 2001.

Shortall, Stacey Anne. "Aboriginal self-government in Aotearoa-New Zealand: a view through the Canadian lens.” Thesis (LL.M.), University of Alberta, 1996.

Smith, Linda Tuhiwai. Decolonizing Methodologies. Dunedin: University of Otago Press, 1999.

Sorrenson, MPK. 'The Waitangi Tribunal and the Resolution of Māori Grievances,' in Land is the Price. Auckland: Auckland University Press, 2014. 
Spoonley, Paul, Pearson, David G. and MacPherson, Cluny. Nga Patai: Racism and Ethnic Relations in Aotearoa New Zealand. Palmerston North: Dunmore Press, 1996.

Spoonley, Paul. Mata Toa: The Life and Times of Ranginui Walker. Auckland: Penguin, 2009.

Stevens, Michael. "Muttonbirds and modernity in Murihiku: continuity and change in Kai Tahu knowledge.” Ph.D Thesis, University of Otago, 2009.

Stokes, Evelyn. Wiremu Tamihana: Rangatira. Wellington: Huia, 2002.

Tavuchis, Nicholas. Mea Culpa: A Sociology of Apology and Reconciliation. Stanford, 1991.

Taylor, Louise Jane. “The Fiscal envelope: a manifesto for finality.” LL.B. (Hons.), Victoria University of Wellington, 1995.

Torpey, John (ed.). Politics and the Past: On Repairing Historical Injustices. Lanham, 2003.

Tuuta, Dion. Mãori Experiences of the Direct Negotiations Process. Wellington: Crown Forestry Rental Trust, 2003.

Vowles, Jack and Aimes, Peter. Voters'Vengeance: The 1990 Election in New Zealand and the fate of the Fourth Labour Government. Auckland: Auckland University Press, 1993.

Walker, Ranginui. Nga tau tohetohe: Years of Anger. Auckland: Penguin, 1987.

---------. Nga pepa a Ranginui: The Walker Papers. Auckland: Penguin Books, 1996

---------. Ka whawhai tonu matou: Struggle without end. Auckland: Penguin, 2004.

--------. Opotiki-Mai-Tawhiti: Capital of Whakatohea. Auckland: Penguin, 2007.

Ward, Alan .A Show of Justice: Racial 'Amalgamation' in Nineteenth Century New Zealand. Auckland: Auckland University Press, $1^{\text {st }}$ ed. 1974, 1995.

--------. National Overview. Wellington: Waitangi Tribunal; GP Publications, 1996.

An unsettled history: Treaty claims in New Zealand today. Wellington: Brigdet Williams Books, 1999.

Weyeneth, Robert R.. "The Power of Apology and the Process of Historical Reconciliation.” The Public Historian, v. 23, no. 3.

Wheen, Nicola \& Hayward, Janine (eds.). Treaty of Waitangi Settlements. Wellington: Bridget Williams Books, 2012.

White, Ben. "Sites of Contestation: Perceptions of Wilderness in the Context of Treaty Claim Settlements," Master of Resource Management thesis, 1994, Lincoln University. 
Williams, David V. Te Kooti Tango Whenua: The Native Land Court 1864-1909. Wellington: Huia Books, 1999.

Wilson, Margaret and Anna Yeatman, eds. Justice \& Identity: Antipodean Practices.

Wellington: Bridget Williams Books, 1995.

Young, David. Our Islands, Our Selves: A History of Conservation in New Zealand. Dunedin: Otago University Press, 2004.

\section{Waitangi Tribunal Reports and other unofficial documents}

JG Bentinck-Stokes, "Report on Legal and Historical Aspects of the Taranaki Confiscations," 20 May 1981, Wai 143, A26;

Innes, Craig and Mitchell, James. "Alienation of Māori granted lands within Te Rohe Pōtae Parish extension, 1863-2011.” Report Commissioned by the Waitangi Tribunal, Wai 898, \#A30, 2013.

Marr, Cathy. Public Works Takings of Māori Land: 1840-1981, Rangahaua Whānui National Theme G. Wellington: Waitangi Tribunal, 1997.

---------. “Te Rohe Pōtae political engagement 1864-1886,” Report commissioned by the Waitangi Tribunal, Wai 898, \#A78, 2011.

O’Malley, Vincent. “Te Rohe Pōtae War \& Raupatu: A Report Commissioned by the Crown Forest Rental Trust,” 2010.

O’Regan, “Sir Tipene. Te Kereme: The Claim, Lecture Two.” Macmillan Brown Lecture Series 1998.

Waitangi Tribunal Waitangi Tribunal, Report of the Waitangi Tribunal on the Manukau Claim (Wai-8). Wellington: Waitangi Tribunal, 1985.

--------. Report of the Waitangi Tribunal on the Orakei Claim (Wai-9). Wellington: Brookers \& Friends, 1987.

Ngai Tahu Report. Wellington: Waitangi Tribunal, 1991, 3 Vols.

The Ngai Tahu Claim: Supplementary Report on Legal Personality. Wellington:

Waitangi Tribunal, 1991.

--------. Ngai Tahu Sea Fisheries Report. Wellington: Waitangi Tribunal, 1992.

---------. Ngai Tahu Ancillary Claims Report. Wellington: Waitangi Tribunal, 1995.

---------. The Turangi Township Remedies Report, Wellington: Waitangi Tribunal, 1995 
---------. Te Raupatu o Tauranga Moana: Report on the Tauranga Confiscation

Claim, Wellington: Waitangi Tribunal, 2004.

Ngati Kahu Remedies Report, Wellington: Waitangi Tribunal, 2012,

Mangatu Remedies Report, Wellington: Waitangi Tribunal, 2013.

\section{Websites}

"Marginals strips," <<http://www.linz.govt.nz/survey-titles/cadastralsurveying/publications/marginal-strips $>>$. Accessed 11 January 2012.

"Confiscation of Māori land." <http://www.teara.govt.nz/en/map/27791/confiscation-ofMāori-land>. Accessed 24 April 2013.

"Ngā Hoko i Ngāi Tahu."

$<<$ http://www.tiritiowaitangi.govt.nz/maps/ngaitahupurchases.php $>>$. Accessed 24 April 2013.

"The Settlement." < $<$ http://www.ngaitahu.iwi.nz/About-Ngai-Tahu/Settlement/> . Accessed 4 May 2013. 